\title{
MECHANISMS OF STRENGTH LOSS \\ IN STIFF CLAYS
}

by

\section{Timothy D. Stark}

Dissertation submitted to the Faculty of the Virginia Polytechnic Institute and State University in partial fulfillment of the requirements for the degree of

DOCTOR OF PHILOSPHY

in

Civil Engineering

APPROVED :

T.M. Duncan, Chairman

G. W. Clough

T. Ruppusaty

R. D. Rrebs

M. P. Singh

$$
\text { July, } 1987
$$

Blacksburg, Virginia 


\section{ABSTRACT}

On September 14, 1981 a major slide was discovered in the upstream slope of San Luis Dam, located about 100 miles southeast of San Francisco, California. The slide occurred at the end of a period of rapid drawdown of the reservoir. Although this was the longest and fastest drawdown in the life of the dam, 180 feet in 120 days, there had been seven previous cycles of drawdown, some nearly as severe as the one that preceded the slide.

Field measurements showed the slide was caused by the clayey slopewash material left in the foundation of the dam during construction. Although the slopewash was dry and extremely strong when the embankment was built, it apparently was weakened considerably when submerged beneath the reservoir and its strength was further degraded by cyclic loading affects as the reservoir level was raised and lowered during the 14 years preceding the slide.

The objective of this research was to gain a better understanding of the mechanisms of strength loss in the slopewash that resulted in the 1981 slide at San Luis Dam. This was accomplished using laboratory tests on undisturbed samples of slopewash, analyses of seepage through the embankment and foundation, finite element analyses of stresses in the dam during construction and operation of 
the reservoir, and conventional equilibrium slope stability analyses.

The laboratory tests showed that the shear strength of the slopewash decreases very quickly when the desiccated material is wetted. Wetting causes immediate reduction in shear strength to the fully softened value, and there is no lasting effect of consolidation by drying. After wetting the highly desiccated slopewash has the same strength as in the remolded, normally consolidated condition.

Tests that simulated cyclic changes in normal stress and shear stress like those during drawdown and refilling of the reservoir showed that further strength loss results from cyclic loading of the slopewash. Cyclic loading at stress levels below the fully softened peak strength result in continual shear displacement, and eventually, when the cumulative horizontal displacement reaches approximately ten inches, the shear strength is reduced to its residual value. 


\section{ACRNOWLEDGEMENTS}

The author wishes to acknowledge the debt of gratitude owed his advisor, Professor J. M. Duncan, for his guidance and support throughout the course of his studies. Without his assistance and patient review of the manuscript, this dissertation would not have been possible.

Professors G. W. Clough, R. D. Krebs, T. Ruppusamy and M. P. Singh also reviewed the manuscript and offered helpful suggestions for improving the clarity of the presentation.

The research was funded by the U. S. Bureau of Reclamation under Contract No. 5-CR-81-07990. The assistance provided by DeWayne Campbell, Becky Morfitt and Paul knodel of the Bureau of Reclamation is greatly appreciated.

The author would like to thank Mr. Erli Ma of the Xian Highway Institute in Xian, China for his assistance and friendship during the long hours spent in the soils laboratory.

A very special thanks goes to Joan Stumpf for her patience and assistance in preparing the manuscript and her loving support throughout the author's post-graduate career. Finally, the author would like to thank his family and Ann Duncan for their support. 
TABLE OF CONTENTS

Page

ACRNOWLEDGEMENTS

iv

LIST OF FIGURES

LIST OF TABLES

LIST OF SYMBOLS

CHAPTER ONE - Introduction

The Slide at San Luis Dam

Unanswered Questions

Research Studies

CHAPTER TWO - Review of Literature on Stiff Clays

viii

xvii

ixx

Shear Characteristics of Overconsolidated Clay

Progressive Failure in Stiff Fissured Clays

Design of Slopes in Stiff Clays

General Summary of Previous Work : • • 15

\section{CHAPTER THREE - Compressibility and Shear Strength of the Slopewash Material}

Introduction

Slopewash Index Properties

Preparation of Test Specimens from the

Upstream Block Samples

Upstream Block Samples
Preparation of Test Specimens from the

Downstream Block Samples.

Preparation of Remolded Test Specimens

Consolidation Tests on Upstream Samples

Consolidation Tests on Downstream Samples

Drained Direct Shear Tests

Direct Shear Test Procedure

Direct Shear Tests on Downstream Samples

Direct Shear Tests on Upstream Samples

Strength of Mechanically Overconsolidated

Specimens.

Tests on Downstream Block $36 \mathrm{~F}-765$ :

UU Triaxial Tests

CU Triaxial Tests

Summary 
CHAPTER FOUR - Analysis of Time Lag in Pore Pressures During Drawdown

Introduction

Geologic Conditions

Piezometer Locations

Reservoir History

Soil Properties for Analysis

Analysis Procedure

Boundary Conditions

Adjustment of Soil Properties

Calculated Pore Pressures in the Slopewash

Migration of Phreatic Surface

CHAPTER FIVE - Analyses of the Stability of the Upstream Slope of San Luis Dam . . . 130

Cross Section Analyzed . $\quad . \quad \ldots \quad$. $\quad . \quad 131$

Shear Strength Parameters $\quad \cdot \quad \cdot \quad \cdot \quad \cdot \quad \cdot 133$

Calculated Factors of Safety $\quad$. $\quad$ - $\quad$ • $\quad$ - 135

Summary

CHAPTER SIX - Finite Element Analysis of Stresses in the Embankment and Foundation . 141

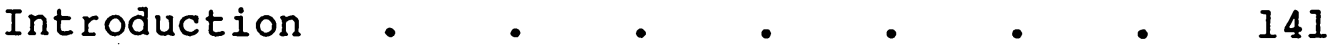

Soil Properties for Analysis : $\quad \cdot \quad \cdot \quad \cdot \quad 141$

Analysis Procedures • $\quad . \quad \cdot \quad \cdot \quad \cdot \quad 144$

Calculated Stresses on the $198 \dot{1}$ slide Plane : 147

Stress Path for Laboratory Direct Shear

Summary

Specimens • • • • • • • .

157

CHAPTER SEVEN - Strength Loss Due to Cyclic Loading 158

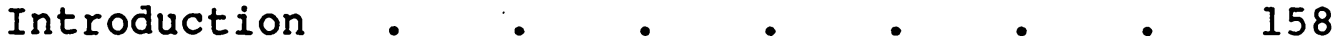

Cyclic Direct Shear Test Procedure: $\quad$ : $\quad$ : 158

First Cyclic Direct Shear Test . • . 159

Second Cyclic Direct Shear Test . • . 172

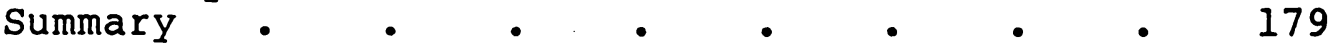


Page

CHAPTER EIGHT - Stability and Performance of San Luis Dam After Construction of Stabilizing Berm

Introduction

Review of Movements Measured Düring the

Finite Element Model.

$\bullet \quad \bullet \quad \cdot \quad \cdot \quad 188$

Soil Properties for Analysis • • • • . 190

Analysis Procedure

190

Calculated Movements During 1984 Drawdown • 194

Estimated Performance of San Luis Dam During

$$
\text { Future Large Drawdown Cycles }
$$

Stability of San Luis Dam

Summary

\section{CHAPTER NINE - Conclusions}

Conventional Consolidation and Direct

Shear Tests

Transient Seepage Analyses

Slope Stability Analyses

Cyclic Direct Shear Tests

Performance and stability of the Repaired

APPENDIX A - San Luis Dam - Facts and Figures

APPENDIX B - Results of Laboratory Consolidation Tests

APPENDIX C - Results of Laboratory Direct Shear Tests 


\section{LIST OF FIGURES}

Number

Page

1-1 Estimated Upstream Slide Plane at Station 135+00 2

1-2 Typical Slope Indicator Data from Station 135+00 4

2-1 Shear Characteristics of Stiff Clays from Skempton (1964)

2-2 Fully Softened Condition in Stiff Clays from Skempton (1970) • $\quad$ • . . .

3-1 Comparison of Slopewash Samples Tested During the 1981 and the current Investigations . . 20

3-2 Typical Slopewash Gradation . • • • 21

3-3 Consolidation Tests on Soaked and Unsoaked Upstream Slopewash Samples $•$ • $\quad$ • 27

3-4 Consolidation Test on Unsoaked Downstream

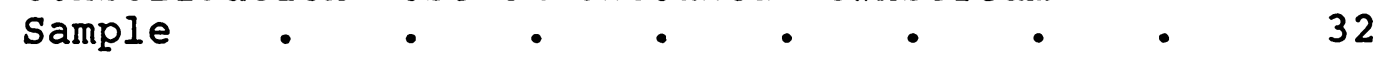

3-5 Consolidation Test on Soaked Downstream Slopewash Sample • • • • • • 33

3-6 Effect of Direct Shear Sample Thickness . . 35

3-7 Shear Stress-Deformation Curves for Drained Direct Shear Tests on Remolded Slopewash • 36

3-8 Shear Stress-Deformation Curves for Drained Direct Shear Tests on Unsoaked Downstream Slopewash . 40

3-9 Direct Shear Test on Downstream Slopewash • 44

3-10 Effect of Soaking on Downstream Slopewash in Direct Shear • • • . . . . 45

3-1l Downstream Slopewash Failure Envelopes • • 47

3-12 Upstream Slopewash Failure Envelopes • . 51

3-13 Direct Shear Tests on Mechanically
Overconsolidated Slopewash . . . 54

3-14 Comparison of Overconsolidation by Desiccation
and External Pressure.$\quad \cdot \quad \cdot \quad 56$ 
3-15 Comparison of Direct Shear Test on Red Slopewash with Results for Grey Slopewash • • .

3-16 Stress-Strain Curves for UU Triaxial Tests on Upstream Slopewash Samples • . • •

3-17 UU Triaxial Tests on Upstream Slopewash • •

3-18 Stress-Strain and Pore Pressure-Strain Curves for CU Triaxial Tests on Upstream Slopewash Samples

3-19 Effective Stress-Strength Envielope from CU Triaxial Tests on Upstream Slopewash

4-1 Cross Section at Station 135+00 . . . 70

4-2 Location of Vibrating Wire Piezometers at Station $135+00$ -. . . . .

4-3 Actual and Approximated Reservoir History (Bureau of Reclamation, 1981) • . .

4-4 Variations of Pressure Head with Volumetric Moisture Content $\quad . \quad$. $\quad$. $\quad$. $\quad$.

4-5 Variations of Pressure Head with Volumetric Moisture Content Used in Seepage Analyses

4-6 Variation of Relative Permeability with Volumetric Moisture Content after Mitchell et al. (1965)

4-7 Full Seepage Analysis Mesh at Station 135+00 .

4-8 Slopewash Seepage Analysis Mesh at Station 135+00 86

4-9 Comparison of Results Calculated Using Full and Slopewash Meshes

4-10 Zone 1 Seepage Analysis Mesh at Station 135+00 89

4-1l Comparison of Results Calculated Using Full and $\mathrm{Z}$ one 1 Meshes

4-12 Full Seepage Analysis Mesh and One Dimensional Column at Station $135+00$. . . . 
Number

Page

4-13 Comparison of Results Calculated Using Full Mesh and a One Dimensional Column Mesh . . . 92

4-14 Foundation Piezometer Measurements . $\quad$ - . 94

4-15 Zone 1 and 3 Piezometer Measurements . $\quad 96$

4-16 Slopewash Piezometer Measurements • $\quad$ • 99

4-17 Comparison of Measured Heads at Piezometer 135-9

During 1984 Drawdown, with Values Calculated

Using Initial Soil Properties . . . . 101

4-18 Comparison of Measured Heads at Piezometer 135-9

During 1984-85 Filling, with Values Calculated

Using Initial Soil Properties . . . .

4-19 Comparison of Measured Heads at Piezometer 135-9

During 1985 Drawdown, with Values Calculated

Using Initial Soil Properties . . . . 103

4-20 One Dimensional Finite Element Meshes used for Analyses of Seepage at Piezometer Locations .

4-21 Comparison of Measured Heads at Piezometer 135-9 During 1984 Drawdown, with Values Calculated Using Calibrated Soil Properties • • • • 107

4-22 Comparison of Measured Heads at Piezometer 135-9 During 1984-85 Filling, with Values Calculated Using Calibrated Soil Properties . . .

4-23 Comparison of Measured Heads at Piezometer 135-9 During 1985 Drawdown, with Values Calculated Using Calibrated Soil Properties . . .

4-24 Comparison of Measured Heads at Piezometer 135-8 with Values Calculated Using Calibrated

Soil Properties

4-25 Comparison of Measured Heads at Piezometer 135-3 with Values Calculated Using Calibrated

Soil Properties

4-26 Comparison of Measured Heads at Piezometer 136-1 with Values Calculated Using Calibrated

Soil Properties 
Number

Page

4-27 Calculated Pore Pressures at Top of Slopewash

4-28 Calculated Pore Pressures at Middle of Slopewash

4-29 Calculated Pore Pressures at Top of Slopewash At the Time of the 1981 Slide . . . .

4-30 Calculated Pore Pressures at Middle of Slopewash At the Time of the 1981 Slide . . . .

4-31 Pore Pressure Distributions in the Slopewash Used by the Bureau of Reclamation (1984) for Analysis of the 1981 slide .

4-32 Pore Pressures in the Slopewash Used for Reanalyses of Stability . . . . .

4-33 Pore Pressures in Zone 1 Used for Reanalyses of Stability . $\quad$. $\quad$. . . .

4-34 Variations of Heads with Time at Piezometers 135-10A, B, and C . . . . .

4-35 Migration of Phreatic Surface at Station $135+00 \quad 127$

5-1 Estimated Upstream Slide Plane at Station 135+00 132

6-1 Finite Element Mesh at Station 135+00 • 145

6-2 Calculated Shear and Normal stresses at End of Construction and with Reservoir Full . .

6-3 Effect of Pore Pressures on the Shear and Normal Stresses for the Reservoir Down Condition .

6-4 Shear and Normal Stresses for the End of Construction and Reservoir Down Conditions .

6-5 Reservoir Down Stress Conditions for Use in the Cyclic Direct Shear Tests . . . .

6-6 Stress Path in Zone A for Cyclic Direct Shear Tests

6-7 Stress Path in Zone B for Cyclic Direct Shear Tests 
Number

$\underline{\text { Page }}$

7-1 End of Construction and Reservoir Full Conditions in First Cyclic Direct Shear Test . .

7-2 First Seven Reservoir Cycles in First Cyclic Direct Shear Test . • . . •

7-3 Horizontal Displacement During First Nine Reservoir Cycles in First Cyclic Direct Shear Test

7-4 Horizontal Displacement per Reservoir Cycle in First Cyclic Direct Shear Test. . .

7-5 Total Displacement per Reservoir Cycle in First Cyclic Direct Shear Test

7-6 Total Displacement During the Drawdown Condition in the First Cyclic Direct Shear Test . . 171

7-7 Second Cyclic Direct Shear Test • • • 173

7-8 Horizontal Displacement per Reservoir Cycle in Second Cyclic Direct Shear Test . .

7-9 Total Displacement per Reservoir Cycle in Both Cyclic Direct Shear Tests . • .

7-10 Total Displacement During the Drawdown Condition in Both Cyclic Direct Shear Tests . . .

8-1 Upstream Slide and Repair at Station 135+00 .

8-2 Slope Indicator 135-7 at Station $135+00$ During 1984 Drawdown (Dept. of Water Resources, 1984)

8-3 Slope Indicator 135-11 at Station 135+00 During 1984 Drawdown (Dept. of Water Resources, 1984)

8-4 Measured and Calculated Movements of Selected Surface Points, Station 135+00, San Luis Dam.

8-5 Finite Element Mesh for Analysis of 1984 Movements at Station $135+00$

8-6 Comparison of Measured and Calculated Displacements Along Section A-A at Station $135+00$. 
8-7 Comparison of Measured and Calculated

Displacements Along Section B-B at

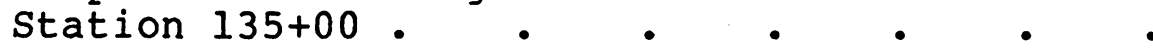

8-8 Calculated Displacements Along Berm-Embankment Interface at Station $135+00$. . . .

8-9 Calculated Horizontal Stresses Along BermEmbankment Interface at Station $135+00$

8-10 Calculated Possible Displacements Along Section $A-A$ at Station $135+00$ During Future Drawdowns

8-11 Calculated Possible Displacements Along Section B-B at Station 135+00 During Future Drawdowns

8-12 Calculated Possible Displacements Along BermEmbankment Interface at Station $135+00$

During Future Drawdowns . . . .

8-13 Calculated Possible Changes in Horizontal Stress Along Berm-Embankement Interface During Future Drawdowns

8-14 Slide Planes Used in Stability Analyses, Station $135+00$.

B-1 Consolidation Test CON1101\#1 on Upstream Slopewash

B-2 Consolidation Test CON1101\#2 on Upstream Slopewash

B-3 Consolidation Test RCONIl01\#3 on Upstream Slopewash.

B-4 Consolidation Test CONl101\#4S on Upstream Slopewash .

B-5 Consolidation Test RCONl101\#5 on Upstream Slopewash .

B-6 Consolidation Test CON1101\#6 on Upstream Slopewash.

B-7 Consolidation Test CON1102\#1 on Upstream Slopewash . 
B-8 Consolidation Test CON1102\#2S on Upstream slopewash

B-9 Consolidation Test CON1102\#3 on Upstream Slopewash.

B-10 Consolidation Test RCON1102\#4 on Upstream slopewash.

B-11 Consolidation Test CON1102\#5H on Upstream Slopewash.

B-12 Consolidation Test CON1102\#6' on Upstream

B-13 Consolidation Test CONl103\#1S on Downstream slopewash.

B-14 Consolidation Test RCON1103\#2 on Downstream slopewash.

B-15 Consolidation Test RCON1103\#3 on Downstream slopewash

B-16 Consolidation Test CON1103\#4 on Downstream Slopewash

B-17 Consolidation Test CON765\#1S on Downstream Slopewash

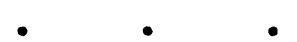

B-18 Consolidation Test RCON765\#2 on Downstream Slopewash

B-19 Consolidation Test RCON765\#3 on Downstream slopewash

B-20 Consolidation Test CON765\#4 on Downstream slopewash

B-21 Consolidation Test RCON765\#5 on Downstream Slopewash

C-1 Direct Shear Test DS1101\#1S on Upstream Slopewash

C-2 Direct Shear Test DS1101\#2S on Upstream Slopewash 252

C-3 Direct Shear Test DSIl01\#3S on Upstream Slopewash 253 
C-4 Direct Shear Test DSI101\#4S on Upstream Slopewash 254

C-5 Direct Shear Test RDS1101\#5 on Upstream Slopewash 255

C-6 Direct Shear Test RDSIl01\#6 on Upstream Slopewash 256

C-7 Direct Shear Test RDSll01\#7 on Upstream Slopewash 257

C-8 Direct Shear Test RDS1101\#8 on Upstream Slopewash 258

C-9 Direct Shear Test DSIl0I\#9\&\#9S on Upstream Slopewash • . $\quad$ • . . . . . 259

C-10. Direct Shear Test DS1101\#9S on Upstream Slopewash 260

C-11 Direct Shear Test DSIl01\#9S on Upstream Slopewash 261

C-12 Direct Shear Test DSI102\#1 on Upstream Slopewash 262

C-13 Direct Shear Test DSII02\#1S on Upstream Slopewash 263

C-14 Direct Shear Test DSI102\#1S on Upstream Slopewash 264

C-15 Direct Shear Test DSI102\#1S (Rerun) on Upstream Slopewash • • • • • • • • • 265

C-16 Direct Shear Test DS1102\#1S on Upstream Slopewash 266

C-17 Direct Shear Test DS1103\#1S on Downstream Slopewash •

C-18 Direct Shear Test DS1103\#2 on Downstream Slopewash •

C-19 Direct Shear Test DSl103\#2S on Downstream

C-20 Direct Shear Test DS1103\#2S on Downstream

C-21 Direct Shear Test DS1103\#2S on Downstream

C-22 Direct Shear Test RDSl103\#3 on Downstream Slopewash . $•$.

C-23 Direct Shear Test RDS1103\#4 on Downstream Slopewash • • • • • • • 
C-24 Direct Shear Test DS1103\#5 on Downstream Slopewash • • • •

C-25 Direct Shear Test Dsil03\#5S on Downstream Slopewash.

C-26 Direct Shear Test DS1103\#6 on Downstream slopewash

C-27 Direct Shear Test DS1103\#6S on Downstream slopewash.

C-28 Direct Shear Test DS1103\#7 on Downstream Slopewash.

C-29 Direct Shear Test DSI103\#7S on Downstream Slopewash . $\quad$ • . . • .

C-30 Direct Shear Test DSII03\#8\& \#8S on Downstream Slopewash

C-31 Direct Shear Test DS765\#1\& \#IS on Downstream Slopewash • • • • • • • •

C-32 Direct Shear Test OCDS\#1 on Downstream Slopewash

C-33 Direct Shear Test OCDS\#2 on Downstream Slopewash

C-34 Direct Shear Test OCDS\#3 on Downstream Slopewash

C-35 Direct Shear Test OCDS\#4 on Downstream slopewash. 


\section{LIST OF TABLES}

Number

Page

1-1 Slopewash, Zone 1 and Zone 3 Characteristics.

3-1 Index Properties of the Upstream and Downstream Slopewash Samples . . . . . .

3-2 Summary of Consolidation Tests on Upstream

Sample 36F-1101 . . . . . . . 25

3-3 Summary of Consolidation Tests on Upstream

Sample 36F-1102 $\quad$ • . . . . . . . 26

3-4 Summary of Consolidation Tests on Downstream

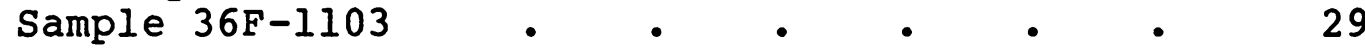

3-5 Summary of Consolidation Tests on Downstream

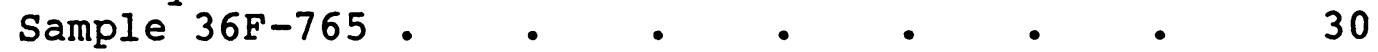

3-6 Summary of Direct Shear Tests on Downstream

Sample 36F-ll03 • • • • • • •

3-7 Summary of Direct Shear Tests on Upstream

Sample 36F-llol $\bullet$. $\quad$ •

3-8 Summary of Direct Shear Tests on Upstream

Sample 36F-1102 $\quad$ • $\quad$ • $\quad$ •

3-9 Summary of Mechanically Overconsolidated

Direct Shear Tests • • • • • • • 53

3-10 Summary of Direct Shear Test on Downstream

Sample 36F-765 . . . . . . .

3-11 Summary of Strength Parameters for Upstream and Downstream Slopewash • • . • . 66

4-1 Soil Properties Required by UNSATI • • • 75

4-2 Index Properties and Initial Suction Head Values 81

4-3 Measured and Calibrated Values of Saturated Permeability, Specific Storage and Porosity in the Slopewash

4-4 Summary of Material Properties Used in Analyses of the Response of the Slopewash 
Number

$\underline{\text { Page }}$

4-5 Piezometer Locations and Boundary Conditions .

4-6 Results of a Parametric study on the seepage Properties of the Slopewash . . .

5-1 Moist Unit Weights and Drained Shear Strength Parameters for the San Luis Dam Embankment and Foundation Materials $\quad . \quad$. $\quad . \quad$.

5-2 Calculated Factors of Safety for the Upstream Slope of San Luis Dam . . . .

6-1 Hyperbolic stress-strain Parameters for the Upstream and Downstream Slopewash .

6-2 Drained Hyperbolic Stress-Strain Parameters for the Embankment Materials . . .

7-1 Stress Conditions Used in the Cyclic Direct

7-2 Summary of Cyclic Direct Shear Test \#1 on Downstream Slopewash

7-3 Summary of Cyclic Direct shear Test \#2 on Upstream Slopewash . . . . .

8-1 Surface and Subsurface Movements Measured During the 1984 Drawdown . . . . .

8-2 Drained Hyperbolic Stress-Strain Parameters for the Slopewash and Slide Zone Materials

8-3 Drained Hyperbolic Stress-Strain Parameters for the Embankment and Berm Materials .

8-4 Drained Shear strength Parameters for the Slopewash and Embankment Materials used in Stability Analyses

8-5 Factors of Safety for the Upstream Slope During the 1984 Drawdown. 


\section{LIST OF SYMBOLS}

C

$C^{\prime}$

C p

$\mathrm{C}_{\mathrm{r}}^{\prime}$

$\mathrm{Cc}$

$\mathrm{C} \varepsilon \mathrm{C}$

$\mathrm{Kh}$

ko

$\mathrm{Kr}$

$\mathrm{KS}$

$\mathrm{KV}$

OCR

$\mathrm{Pp}$

PI

$r_{\mathrm{u}}$

Ss

$s_{r}$

$s_{f}^{\prime}$

$\sigma_{1}$

$\sigma_{3}$

$\sigma_{3 c}$

$\sigma^{\prime}$

$\sigma^{\prime} n$

$\phi$

Cohesion

Effective cohesion

Effective peak cohesion

Effective residual cohesion

Compression index

Modified compression index

Horizontal saturated permeability

Earth pressure coeffient

Relative permeability

Saturated permeability

Vertical saturated permeability

Overconsolidation ratio

Preconsolidation pressure

Plasticity index

Pore pressure ratio

Specific storage

Residual shear strength

Peak shear strength

Major principal stress

Minor principal stress

Confining pressure

Effective stress

Effective normal stress

Angle of internal friction 


$\begin{array}{ll}\phi^{\prime} & \begin{array}{l}\text { Effective angle of internal friction } \\ \phi^{\prime} \quad\end{array} \quad \begin{array}{l}\text { Effective residual angle of internal } \\ \text { friction }\end{array} \\ \phi^{\prime} p \quad \begin{array}{l}\text { Effective peak angle of internal } \\ \text { friction }\end{array} \\ \phi^{\prime} s \quad \begin{array}{l}\text { Effective fully softened angle of } \\ \text { internal friction }\end{array} \\ n \quad \text { Porosity } \\ \psi \quad \text { Pressure head } \\ \psi_{0} \quad \text { Initial pressure head } \\ \theta \quad \text { Volumetric moisture content }\end{array}$




\section{CHAPTER ONE - Introduction}

\section{The Slide at San Luis Dam}

On September 14, 1981 a major slide was discovered in the upstream slope of San Luis Dam, located about 100 miles southeast of San Francisco, California. A cross section through the slide is shown in Figure 1-1. It can be seen that the slide involved a major portion of the embankment at Station 135+00, extending from the upper scarp near elevation 550 feet, through the core of the dam, into the embankment foundation, and exiting at the toe of the embankment near elevation 400 feet. By January of 1982, the slide mass had moved about 30 feet, and the slide had grown to encompass a length of about 1700 feet along the upstream slope of the dam.

The slide occurred at the end of a period of rapid drawdown of the reservoir. In the months preceding the slide, the reservoir had been drawn down about 180 feet in 120 days. Although this was the longest and fastest drawdown in the life of the dam, there had been seven previous cycles of drawdown, some nearly as severe as the one that preceded the slide.

Unlike most slides that occur during drawdown, the slide at San Luis Dam was deep-seated and extended into the foundation beneath the upstream slope. Slope indicators 

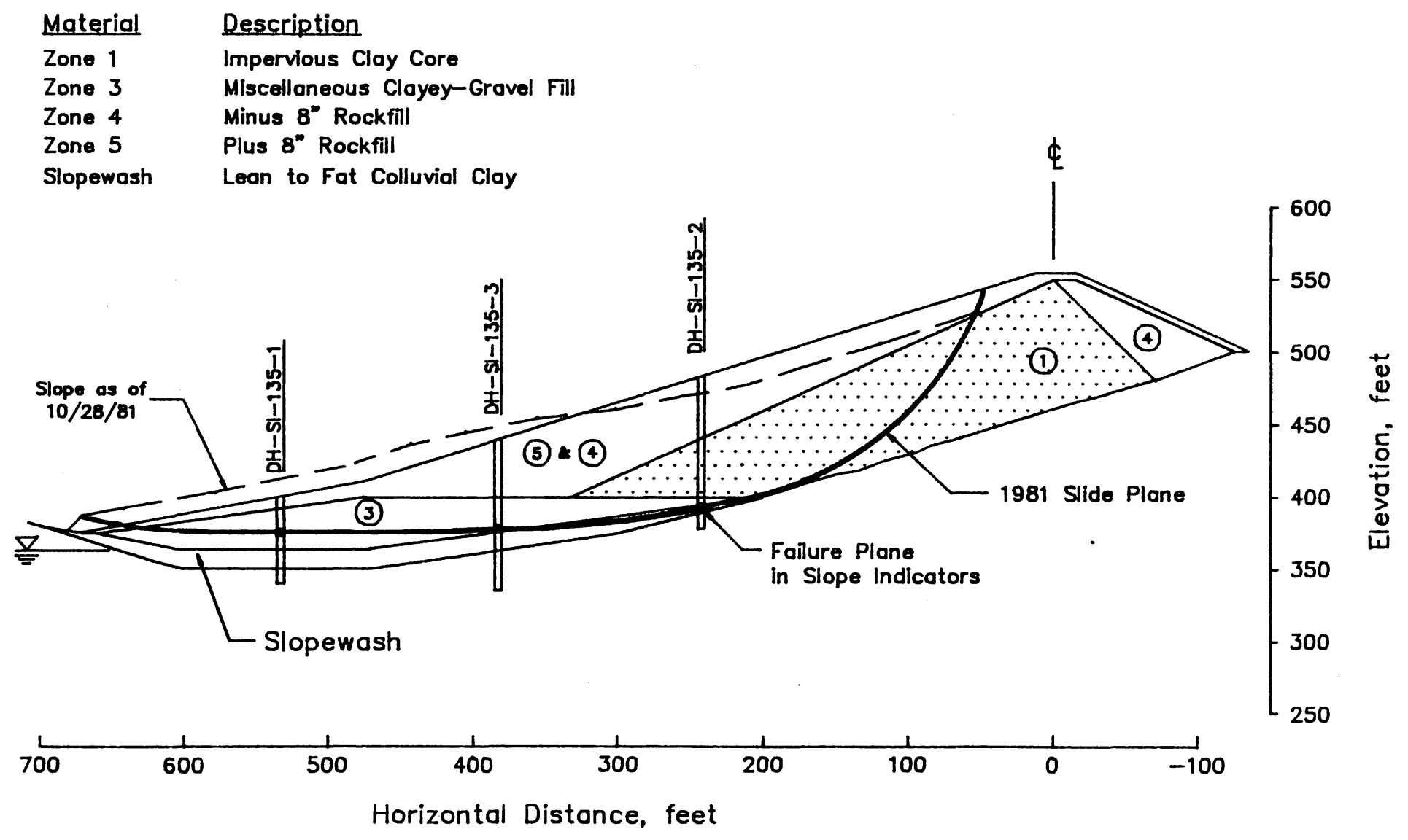

Figure 1-1 Estimated Upstream Slide Plane at Station 135+00 
installed through the slide mass showed a very sharply defined slide plane at a depth of five to ten feet below the top of the foundation. A record from one of these slope indicators is shown in Figure 1-2.

In the area where the slide occurred, the foundation material is a clayey slopewash. Its index properties are summarized in Table 1-1. This material, on which the dam was constructed, had been highly desiccated by drying in the arid climate of the Central valley. At the time the dam was constructed, it was undoubtedly very strong in its dried condition. The specification for stripping of the foundation was:

"C. Excavation for Dam Foundation. --

1. Stripping.--"..."On the abutments loose talus, fault gouge, topsoil and a fat clay layer", (the slopewash), "are to be removed to firm rock or to a horizon whose strength exceeds the overlying embankment. For estimate purposes an average depth of 2 feet was assumed."

Although the slopewash was dry and strong when the embankment was built, it apparently was weakened considerably when submerged beneath the reservoir and wetted thoroughly, and its strength may have been further degraded by cyclic loading effects as the reservoir level was raised and lowered during the 14 year period preceding the slide. 


\section{BOREHOLE DEFLECTIONS RESULTANT DISTANCE PLOTS}

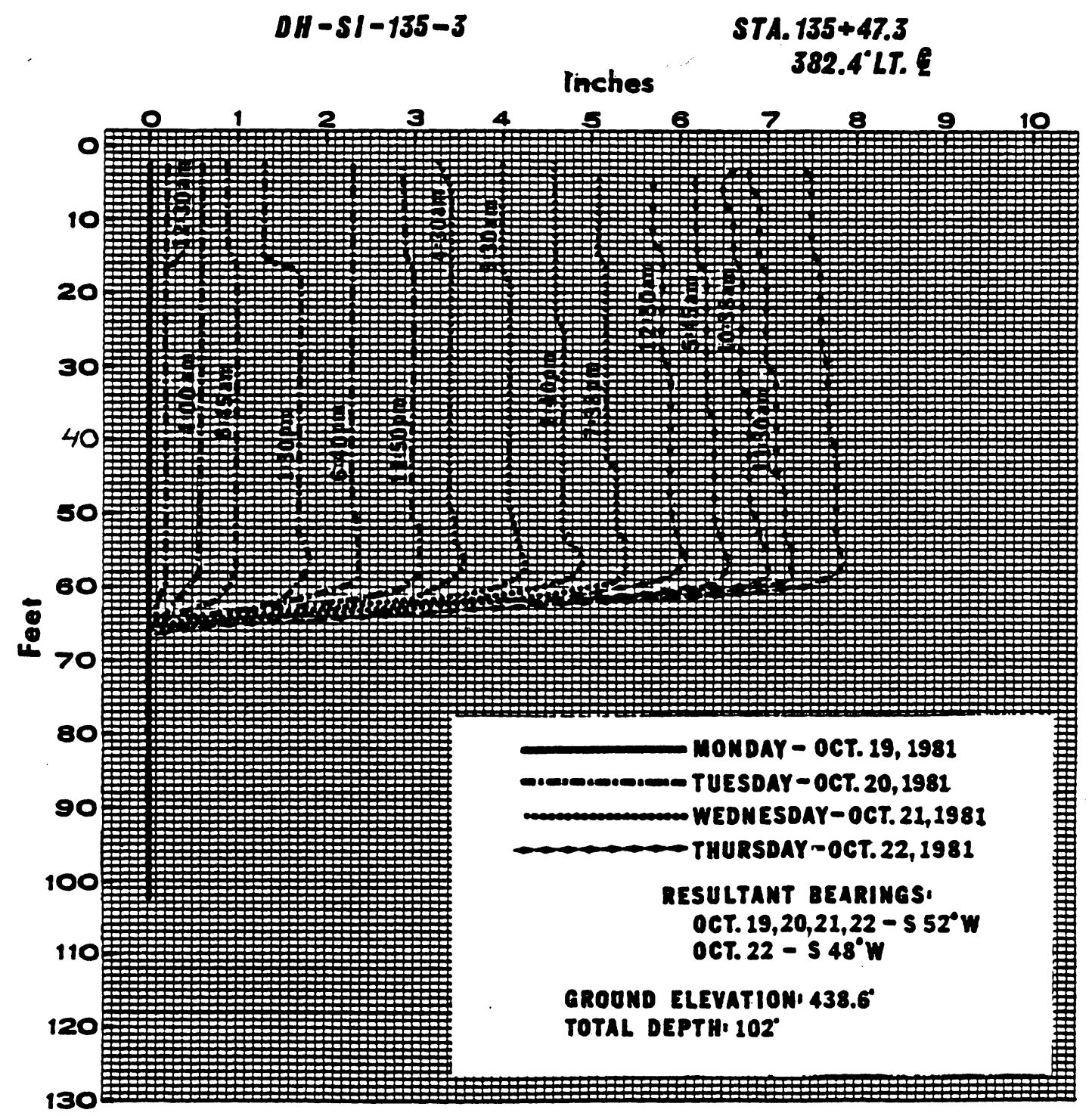

From Bureau of Reclamation (1981)

Figure 1-2 Typical Slope Indicator Data from Station $135+00$ 
TABLE 1-1 - Slopewash, Zone 1 and Zone 3 Characteristics

\begin{tabular}{|c|c|c|c|c|}
\hline \multirow[b]{2}{*}{ Soil Property } & \multicolumn{2}{|c|}{ SLOPEWASH } & \multirow{2}{*}{$\begin{array}{c}\star \\
\text { zoNE } 1 \\
\text { Material } \\
\end{array}$} & \multirow{2}{*}{$\begin{array}{c}* \\
\text { ZONE } 3 \\
\text { Material } \\
\end{array}$} \\
\hline & $\begin{array}{l}\text { Downstream } \\
\text { (Desiccated) }\end{array}$ & $\begin{array}{l}\text { Upstream } \\
\text { (Wetted) }\end{array}$ & & \\
\hline $\begin{array}{l}\text { Natural Water } \\
\text { Content, } 8\end{array}$ & $7-8$ & $18-22$ & 15 & 14 \\
\hline $\begin{array}{l}\text { Plastic } \\
\text { Limit, \& }\end{array}$ & $19-24$ & $20-25$ & 17 & 14 \\
\hline $\begin{array}{l}\text { Liquid } \\
\text { Limit, \& }\end{array}$ & $38-45$ & $37-43$ & $40-47$ & $28-35$ \\
\hline $\begin{array}{l}\text { Plasticity } \\
\text { Index, } q\end{array}$ & $19-21$ & $17-19$ & $23-30$ & $14-21$ \\
\hline
\end{tabular}

Effective Shear Strength Parameters**

$\begin{array}{lllll}\text { Cohesion, psf } & 5500 & 640 & 490 & 475\end{array}$

Friction

$\begin{array}{lllll}\text { Angle, degrees } & 39 & 21 & 26 & 28\end{array}$

* data from Bureau of Reclamation, (1983).

** from CU triaxial tests except downstream slopewash

from drained direct shear tests. 
It is clear that, at the time of the slide, the slopewash material was a weak link with respect to stability of the embankment. Analyses by the Bureau of Reclamation showed that the shear strength of the slopewash was very near its residual value at the time of the slide.

\section{Unanswered Questions}

Although the slide has been repaired and the dam has operated without further incident since 1982, the occurrence of the slide raises several important questions that remain unanswered:

(1) Why did the slide occur in 1981,14 years after construction, during the eighth cycle of drawdown of the reservoir?

(2) How was the strength of the slopewash beneath the upstream slope affected by its being wetted when the reservoir was filled? Was it also affected by the cycles of loading imposed when the reservoir was filled and emptied?

(3) Through what mechanism or mechanisms was the shear strength of the slopewash reduced to its residual value? Since no previous slide had occurred at the site, it would be expected that the shear strength of the slopewash would be at least equal to the fully softened peak strength. 
(4) What shear strength values should be used for design on future projects involving similar types of soils and similar loading conditions?

\section{Research Studies}

To answer these questions, a detailed investigation was undertaken, involving laboratọy tests on undisturbed samples of the slopewash material, analyses of seepage through the embankment and foundation, finite element analyses of stresses in the dam during construction and during operation of the reservoir, and limit equilibrium analyses of the stability. These studies and the results are described in detail in the following chapters.

In addition to the questions regarding shear strength and slope stability, which were the primary focus of these studies, the results of the seepage analyses were also evaluated for purposes of determining the probable rate of advancement of the phreatic surface through the embankment during the years preceding the slide. 


\section{CHAPTER TWO - Review of Literature on Stiff Clays}

In his Rankine Lecture, Skempton (1964) drew attention to the nature and engineering significance of the behavior of' stiff clays. During the twenty years since 1964 Skempton and his colleagues have been at the forefront of the continuing research on stiff clays. Although other

researchers have also contributed to the present state of knowledge regarding the behavior of stiff clays, skempton's research and his design recommendations define the state of the art in this area and this review therefore concentrates on his work.

\section{Shear Characteristics of Overconsolidated_Clay}

Overconsolidated clays commonly exhibit pronounced reduction in shearing resistance when sheared to large displacements in direct shear tests, as shown in Figure 21. As the clay is sheared, the shear stress usually reaches a peak value at a displacement of one-half to one inch. As the shear displacements are increased to larger values, the specimen undergoes softening, until a constant minimum or residual value is reached, usually at a displacement on the order of ten inches. In moving from the peak to the residual value the cohesion, c', decreases to zero and the friction angle also decreases, often by 


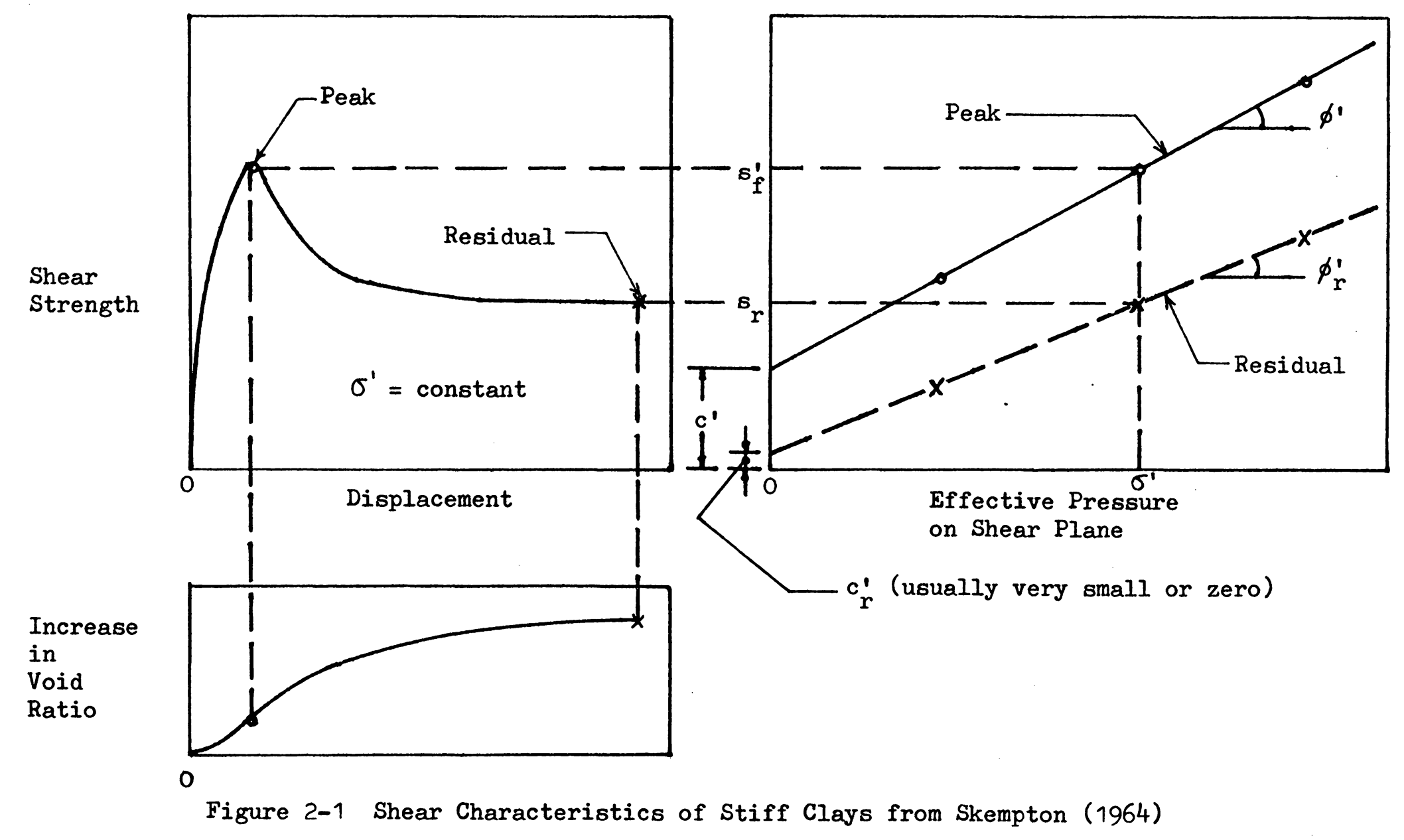


several degrees.

During the shearing process overconsolidated clays tend to dilate, and dilation continues beyond the peak. Part of the drop in strength from peak to residual is therefore due to an increase in void ratio, as shown in Figure 2-1. Of comparable importance is believed to be the reorientation of platy clay minerals parallel to the direction of shearing.

After analyzing a number of landslides in brown London clay, Skempton (1964) found: 1) the failures occurred 30 to 50 years after the slope was excavated and 2) back analyses of the delayed failures showed the shear strength of the clay at the time of failure to be greater than the residual shearing resistance but smaller than the peak strength. As a consequence of these findings Skempton concluded that slides in overconsolidated clays were preceded by a progressive development of a failure surface characterized by reduced shear strength.

\section{Progressive Failure in Stiff Fissured Clays}

Bjerrum (1967) and Skempton (1977) have provided the most widely accepted explanations of progressive failure in overconsolidated clays. Their explanations are similar in that fissures and joints in the clay act as stress concentrators and are essential for a progressive failure. 
Skempton stresses the importance of pore pressure equilibration as the reason for the delayed failures, while Bjerrum stresses the importance of a large recoverable strain energy in the clay as an essential condition for the failure to progress.

In general, the development of a sliding surface by progressive failure usually starts at a discontinuity in the clay mass, eg. a steep erosion slope or a cut at the toe of a larger slope, where failure can be initiated. The removal of load and the large lateral stresses typically found in stiff clays cause the clay to tend to expand laterally. This results in an immediate reduction in pore pressure. As water is absorbed into the clay, the pore pressures equilibrate and the clay softens. Eventually the clay softens to a point where the applied shear stresses equal the strength of the soil and local failure occurs. As the soil continues to deform and its shearing resistance decreases, the excess shear stresses are transferred to the adjacent soil, increasing the shear stresses there. The adjacent soil expands and absorbs water until it fails. Through this mechanism shear stresses are transferred along the slip surface and progressive failure continues until a continuous failure surface has developed, when global sliding and complete failure ensues.

It may thus be concluded that development of a sliding 
surface through progressive failure in a stiff fissured clay is possible if three conditions are satisfied. The first is that the lateral stresses in the clay are large enough to cause stress concentrations that exceed the peak drained shear strength of the clay. Secondly, the clay must expand and lose strength when subjected to shear stresses greater than or equal to the peak shear strength. Thirdly, the clay must exhibit a residual shear strength that is much smaller than the peak shear strength. Based on field piezometer data and back analyses, Skempton (1977) has concluded that the large time required for a failure to occur, usually 40 to 50 years, is due to the very slow rate of pore pressure equilibration.

\section{Design of Slopes in Stiff Clays}

Skempton (1964) concluded that the shear strength along pre-existing slide surfaces that have undergone large movements is equal to the residual value and any subsequent movements on the existing slide plane will be resisted only by the residual value. Prior to about 1970, however, it was not clear what magnitude of shearing resistance could be mobilized in a slope that had not failed previously, and was therefore not at residual.

Based on a number of case histories, Skempton (1970) concluded that in first-time slides the shear strength at 
the time of failure corresponded to a "fully softened condition". The fully softened condition occurs at displacements greater than those required to mobilize the peak strength, as shown in Figure 2-2. Using critical state soil mechanics concepts and back analysis of a number of landslides, Skempton concluded that the fully softened strength parameters were the same as the peak strength parameters for the same clay in a normally consolidated condition. As shown in Figure 2-2 the fully softened condition produces a failure envelope that lies between the peak and residual envelopes. The large strength loss from the peak to the fully softened condition is primarily due to increase in water content, the structural arrangement of the clay particles being similar for both conditions.

Consistent with this understanding of the strength behavior of stiff clays, Skempton (1977) proposed the following design criteria for slopes in stiff fissured clays. For first-time slides, i.e. slopes without preexisting slides or other shear surfaces, the fully softened strength parameters should be used. In slopes where movements greater than one to two meters have occurred along pre-existing shear surfaces, the residual strength parameters should be used. 

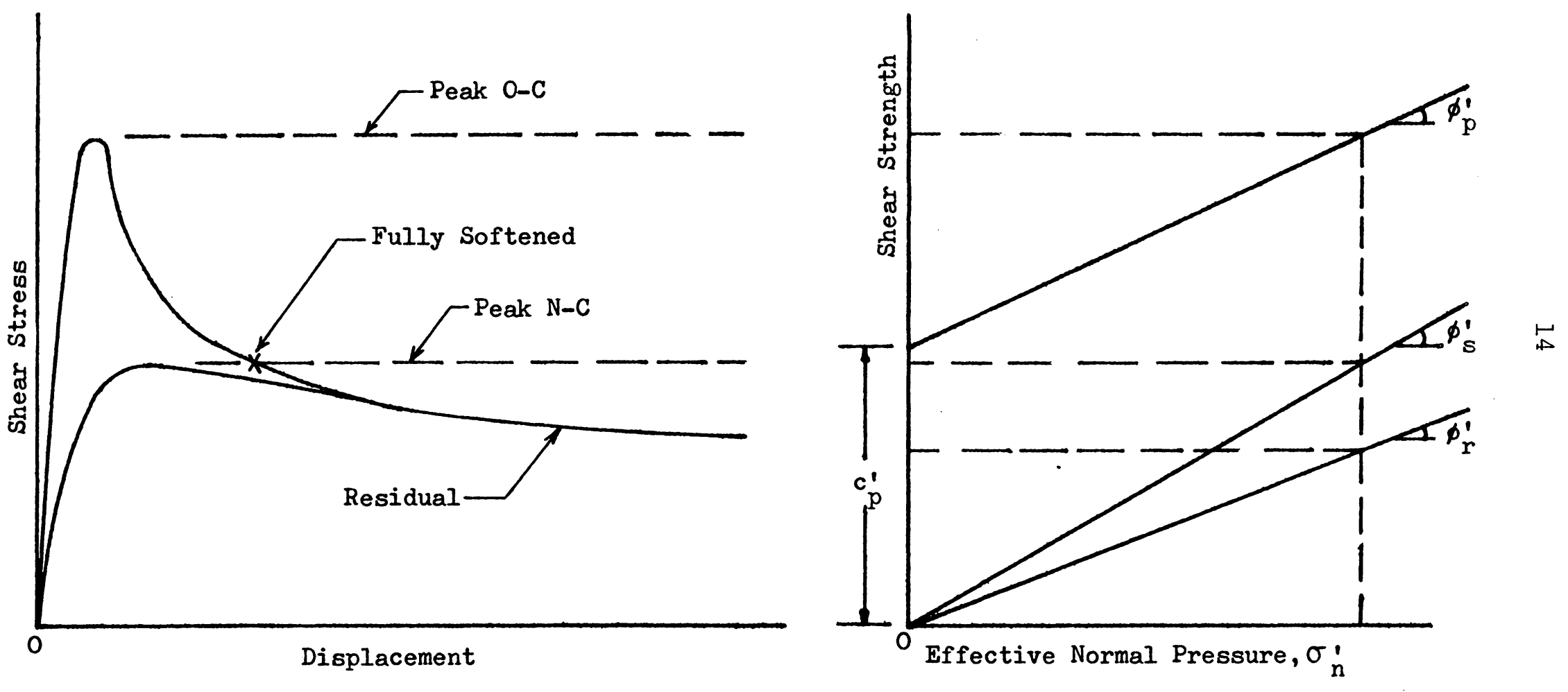

Figure 2-2 Fully Softened Condition in Stiff Clays from Skempton (1970) 


\section{General Summary of Previous Work}

The following conclusions from previous work afford a useful background for the studies described in subsequent chapters.

1) Overconsolidated clays suffer reduction in shearing resistance when subjected to shearing displacements exceeding the value required to mobilize the peak strength.

2) After a slide has taken place, the shear strength along the slip surface is equal to the residual value. The residual strength is associated with strong reorientation of the clay particles and is represented by essentially zero cohesion and a friction angle that is much smaller than the peak value.

3) First-time slides in stiff fissured clays correspond to strengths smaller than the peak value, with essentially zero cohesion.

4) Progressive failure reduces the strength of stiff fissured clay to the fully softened condition. Progressive failure is due to the progressive dilation and weakening of the clay as it absorbs water and initially negative pore pressures dissipate.

5) The shear strength of the clay at the time of 
first sliding in a slope corresponds to the fully softened condition. The fully softened strength is the same as the strength of the clay in a normally consolidated condition.

6) Slopes in previously unsheared material should be designed using the fully softened strength parameters. Slopes that have experienced movements as large as about one meter should be designed using residual strength parameters. 


\section{CBAPTER THREE - Compressibility and Shear Strength of the Slopewash Material}

\section{Introduction}

The laboratory tests described in this chapter were conducted to measure the compressibility and shear strength of the slopewash material in the foundation of San Luis Dam. This was accomplished by performing consolidation and direct shear tests on specimens trimmed from four undisturbed block samples from the site that were provided by the Bureau of Reclamation. Two of the block samples were taken from the foundation on the upstream side of the dam, and had been wetted by the reservoir during operation of the dam. The other two samples were taken from the slopewash on the downstream side of the dam, and were thus representative of the desiccated condition of the slopewash as it was during construction of the dam, before wetting by the reservoir.

The laboratory tests performed during this investigation included consolidation tests, direct shear tests, unconsolidated-undrained (UU) and consolidatedundrained ( $\mathrm{CU}$ ) triaxial tests. These were used to determine the compressibility, the strength and the stressstrain characteristics of the slopewash needed for the slope stability and finite element analyses described in subsequent chapters. 


\section{Slopewash Index Properties}

Table 3-1 lists the index properties of the slopewash ascertained from tests on the four block samples used in this study. Twenty-four of the 27 tests were performed on downstream sample $36 \mathrm{~F}-1103$ and upstream samples $36 \mathrm{~F}-1101$ and 36F-1102. These three samples had very similar index properties, as can be seen in Figure 3-1, and are believed to be representative of most of the foundation slopewash material. The slopewash in these samples is a grey fissured sandy clay containing rock fragments varying in size from coarse sand to cobbles. A gradation curve for slopewash from block $36 \mathrm{~F}-1102$ is shown in Figure 3-2.

The second downstream block sample, 36F-765, has properties that differ quite markedly from the other downstream sample and the two upstream samples. It is considerably more plastic, with a higher liquid limit and plasticity index, and is composed of a red sandy clay with fine gravel-size rock fragments. Due to the somewhat different composition of this sample, the results of the consolidation and direct shear tests performed on specimens from it will be discussed separately in subsequent sections of this chapter.

According to studies done by the Bureau of Reclamation in 1974, the dominant clay mineral in the slopewash is beidellite. Beidellite is a highly active clay mineral 
TABLE 3-1 Index Properties of the Upstream and Downstream Slopewash Samples

\begin{tabular}{|c|c|c|c|}
\hline \multirow[b]{2}{*}{ SOIL PROPERTY } & \multicolumn{2}{|c|}{$\begin{array}{l}\text { DOWNSTREAM } \\
\text { BLOCR SAMPLES }\end{array}$} & \multirow{2}{*}{$\begin{array}{c}\text { UPSTREAM } \\
\text { BLOCR SAMPLES } \\
\text { 36F-1101\& } 1102 \\
\text { (15 values) }\end{array}$} \\
\hline & $\begin{array}{c}36 \mathrm{~F}-1103 \\
(9 \text { values }) \\
\end{array}$ & $\begin{array}{c}36 \mathrm{~F}-765 \\
(3 \text { values }) \\
\end{array}$ & \\
\hline Natural Water Content & $7-88$ & $16-198$ & $18-228$ \\
\hline Plastic Limit & $19-248$ & $30-378$ & $20-258$ \\
\hline Liquid Limit & $38-458$ & $60-728$ & $37-438$ \\
\hline Plasticity Index & $19-218$ & $30-358$ & $18-208$ \\
\hline Degree of Saturation & $50-608$ & $74-778$ & $80-908$ \\
\hline Specific Gravity & 2.70 & 2.75 & 2.70 \\
\hline \multicolumn{4}{|c|}{ Preconsolidation Pressure, $P p$ (tsf) } \\
\hline Unsoaked & $25-30$ & 1.3 & $0.8-1.5$ \\
\hline Soaked & $0.6-1.0$ & 1.1 & $1.0-1.5$ \\
\hline
\end{tabular}

Overconsolidation Ratio, OCR

Unsoaked

Soaked

$$
50-60
$$

$1.2-2.0$
2.6

2.2
$1.6-3.0$

$2.0-3.0$ 


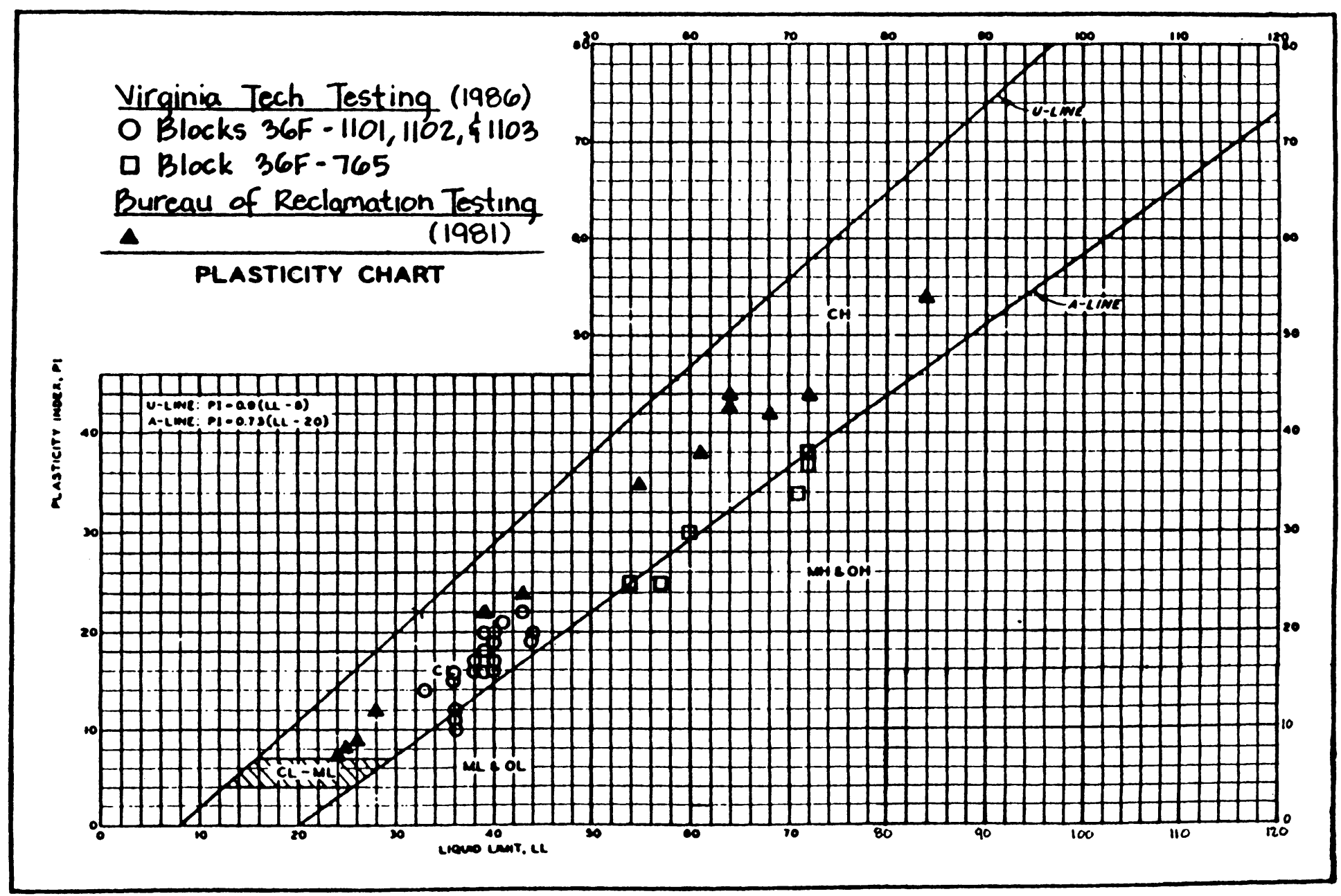

Figure 3-1 Comparison of Slopewash Samples Tested During the 1981 and the Current Investigations 


\section{GRAIN SIZE DISTRIBUTION CURVE}

U. S. STANDARD SIEVE SIZE

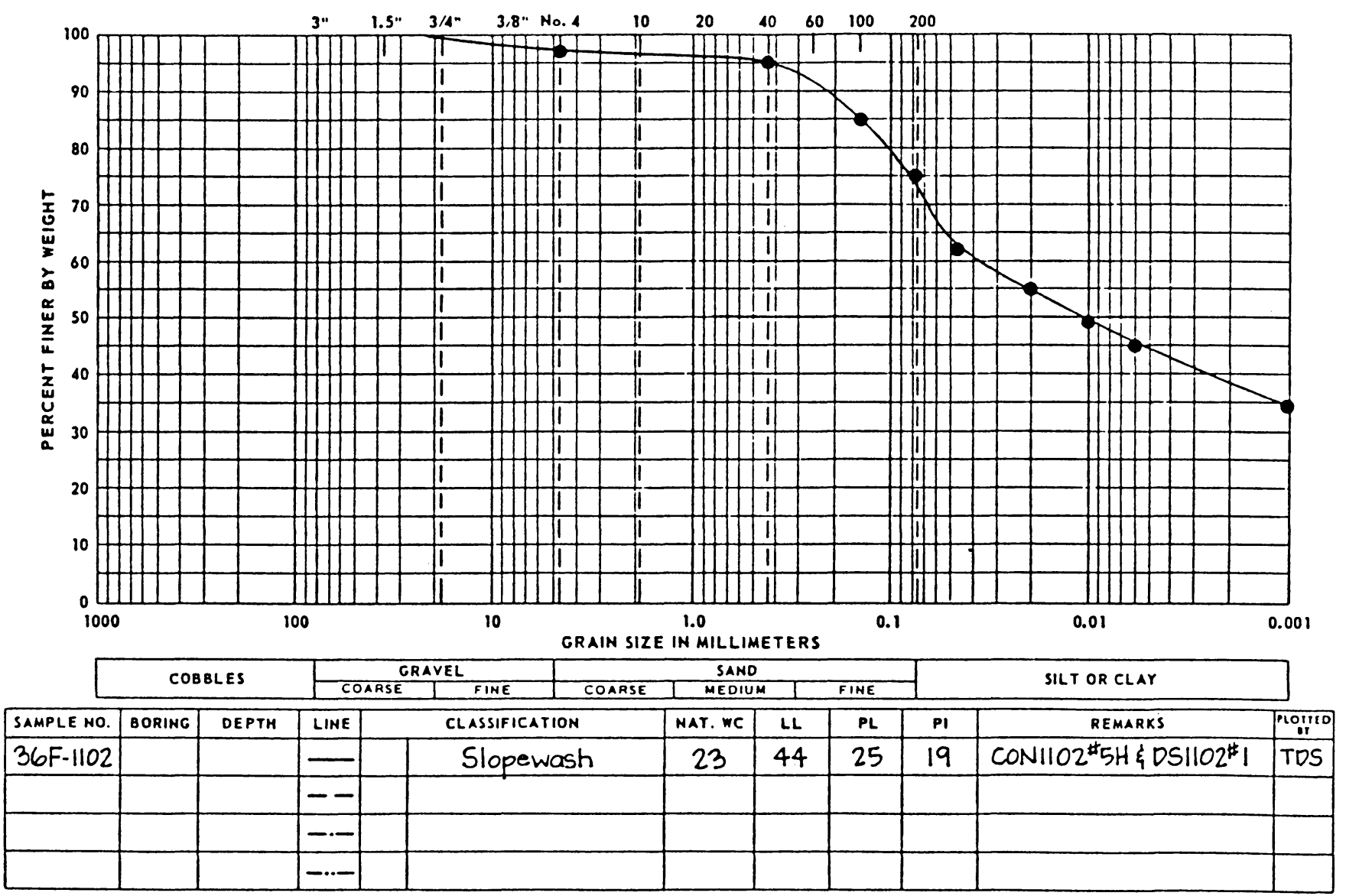

Figure 3-2 Typical Slopewash Gradation 
that exhibits swelling characteristics similar to montmorillonite.

Specimens from both downstream block samples slaked immediately when immersed in distilled water. The red slopewash appeared almost to explode when placed in water, releasing numerous air bubbles when submerged, while the grey slopewash slowly crumbled into a pile of dissociated soil particles. The difference in slaking response is probably due to soil composition, as indicated by the differing Atterberg limits. Neither of the grey upstream slopewash samples slaked noticeably, apparently because they had been previously wetted by the reservoir.

\section{Preparation of Test Specimens from the Opstream Block}

\section{Samples}

The consolidation and direct shear test specimens from the upstream samples were trimmed using a bow saw and single edged razor blades. A four inch square, 0.8 inch frame was used to confine the specimens during trimming. The specimens were extruded from this frame into the direct shear box and a series of 0.1 to 0.2 inch steel spacer plates were used to support the specimens at the elevation required for testing. The upstream consolidation test specimens were trimmed in a similar fashion using a 2.5 inch diameter by 1.0 inch high ring to confine the specimen before it was inserted into the consolidation ring for 
testing. About an hour was required to prepare each specimen for the consolidation tests, while the specimens for the direct shear tests generally required about three hours to prepare.

The triaxial specimens were trimmed to 1.4 inch diameter using a vertical soil lathe and 6.5 inch long surgical razor blades. Extreme care was necessary to prevent pulling the fissured soil apart during trimming, because the specimens had no confinement or support as they stood in the lathe during trimming. Trimming triaxial test specimens from the upstream slopewash typically required about five hours per specimen.

\section{Preparation of Test Specimens from the Downstream Block Samples}

Neither a carpenter's saw nor a bow saw could cut the extremely hard downstream slopewash material. As a result, all the test specimens were trimmed from the blocks using an electric drill with a $1 / 4$ inch carbide-tipped masonry drill bit.

The drill was used to excavate slowly around the frame used to confine the test specimen until about one inch of the slopewash material had passed through the frame. The test specimen was then removed from the block by drilling underneath the frame until enough soil had been removed for the specimen to be broken free from the remainder of the 
block. The ends of the specimen were then planed flush with the frame using the drill and razor blades. Three to four hours were required to trim a consolidation specimen, while the direct shear specimens usually required seven to eight hours. No triaxial specimens were trimmed from the downstream blocks.

\section{Preparation of Remolded Test Specimens}

The remolded consolidation and direct shear test specimens were comprised of soil from previously tested undisturbed specimens. The remolded specimens were mixed from material passing the 100 sieve and were carefully placed in the test apparatus to ensure no voids were present. After the direct shear or consolidation test apparatus was assembled and a testing load applied, the specimens were flooded.

\section{Consolidation Tests on Upstream Samples}

Altogether, twelve consolidation tests, nine using undisturbed test specimens, were performed on the upstream slopewash material. Tables $3-2$ and $3-3$ summarize the results of the tests.

The soaked and unsoaked specimens exhibited similar compressibility characteristics, as illustrated by the strain-log pressure curves shown in Figure 3-3. The 
Table 3-2 - Summary of Consolidation Tests on Upstream Sample 36F-1101

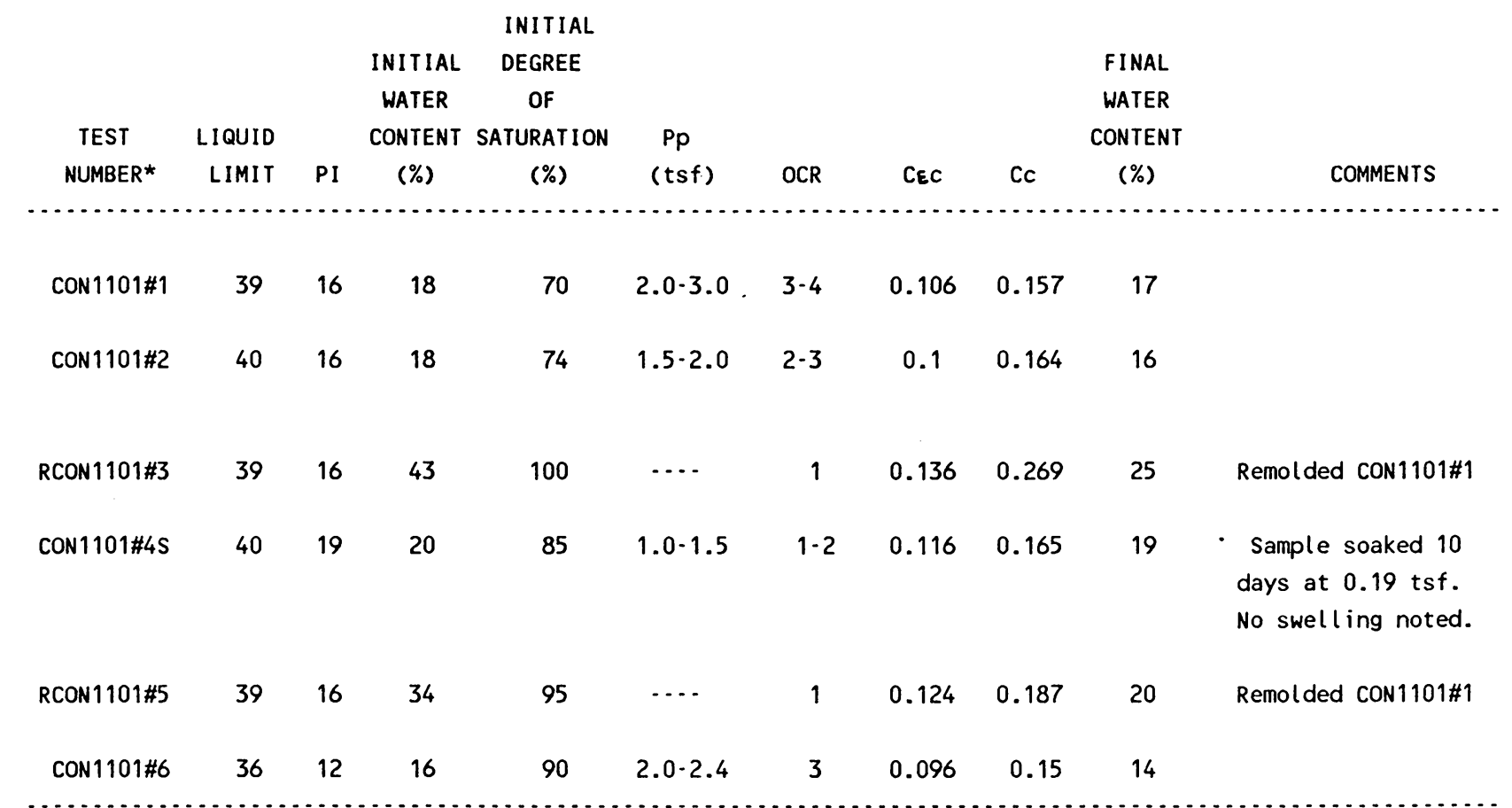

* $R=$ Remolded, otherwise Undisturbed

All specimens 2.50 " diameter, 1.00" initial thickness 
Table 3-3 - Sumary of Consolidation Tests on Upstream Sample 36F-1102

\begin{tabular}{|c|c|c|c|c|c|c|c|c|c|c|}
\hline & & & & INITIAL & & & & & & \\
\hline & & & INITIAL & DEGREE & & & & & FINAL & \\
\hline & & & WATER & OF & & & & & WATER & \\
\hline TEST & LIQUID & & CONTENT & SATURAIION & $\mathrm{Pp}$ & & & & CONTENT & \\
\hline NUMBER* & LIMIT & PI & $(\%)$ & $(\%)$ & $(t s f)$ & OCR & CहC & Cc & (\%) & COMMENTS \\
\hline CON1102\#1 & 39 & 20 & 21 & 84 & $1.4-1.6$ & $4-5$ & 0.130 & 0.220 & 24 & $\begin{array}{l}\text { Sample soaked } 7 \\
\text { days at } 0.06 \text { tsf. } \\
\text { No swell ing noted. }\end{array}$ \\
\hline CON1102\#2S & 41 & 20 & 17 & 66 & $0.8-1.0$ & $2 \cdot 3$ & 0.134 & 0.243 & 18 & $\begin{array}{l}\text { Sample Flooded } \\
\text { Some Disturbance }\end{array}$ \\
\hline CON1102\#3 & 39 & 20 & 19 & 89 & $0.6 \cdot 0.8$ & $1-2$ & 0.132 & 0.195 & 19 . & $\begin{array}{l}\text { Flooded Initially } \\
\text { Some Disturbance }\end{array}$ \\
\hline RCON1102\#4 & 39 & 20 & 49 & 100 & $\cdots$ & 1 & 0.140 & 0.302 & 29 & Remolded CON1102\#3 \\
\hline CON1102\#5H & 44 & 19 & 23 & 96 & $0.8-1.1$ & $2 \cdot 3$ & 0.125 & 0.172 & 12 & Trimmed Horizontally \\
\hline CON1102\#6 & 34 & 13 & 18 & 100 & $0.7 \cdot 1.0$ & $2-3$ & 0.127 & 0.205 & 11 & \\
\hline
\end{tabular}

* $R=$ Remolded, otherwise Undisturbed

All specimens 2.50" diameter, 1.00" initial thickness 


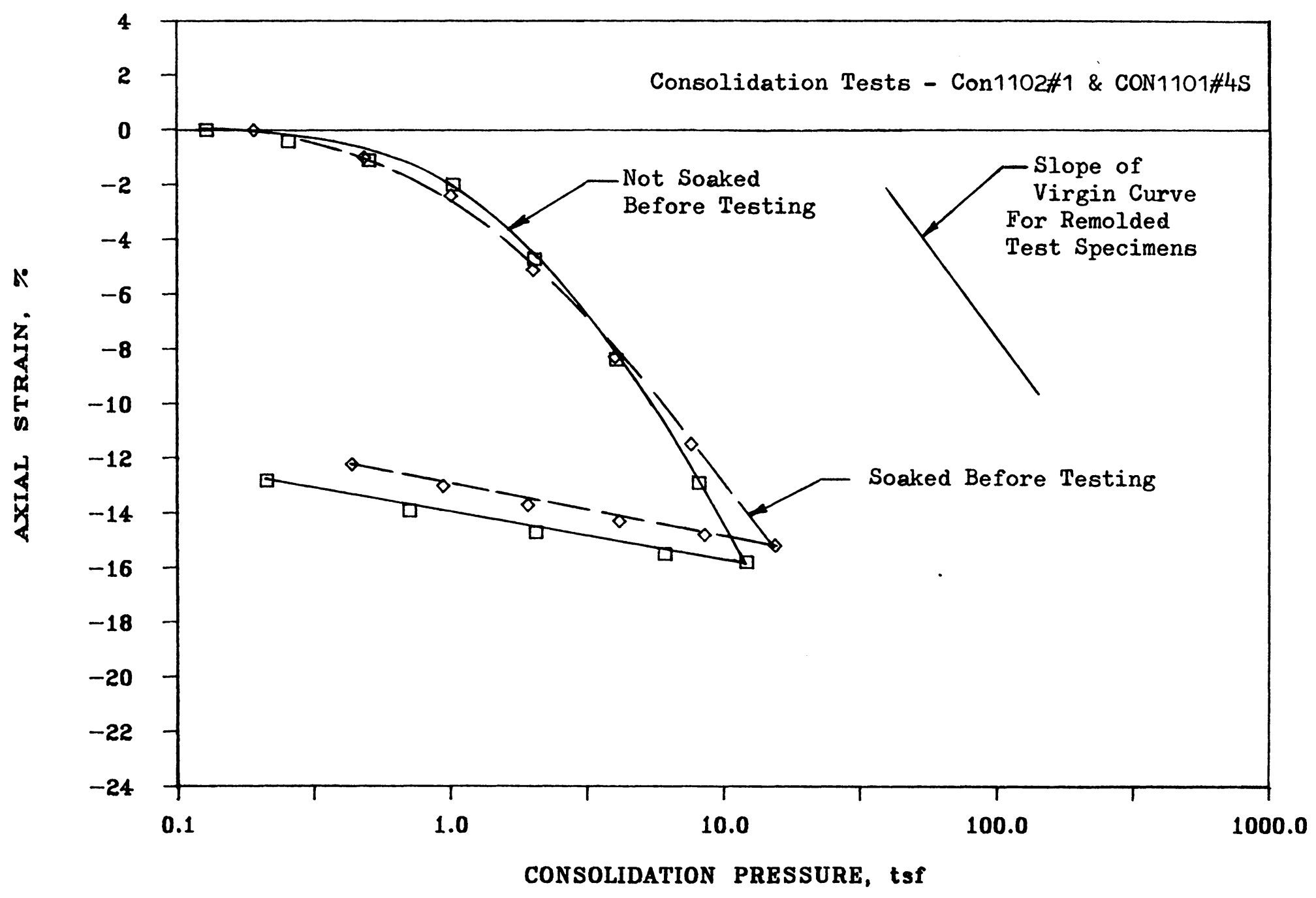

Figure 3-3 Consolidation Tests on Soaked and Unsoaked Upstream Slopewash Samples 
overconsolidation ratios, OCR, for the upstream specimens were found to range from 1.6 to 3.0 , as shown in Table $3-1$. These low values of $O C R$ indicate only slight overconsolidation. The slope of the virgin curve shown in Figure 3-3 was obtained from tests on remolded specimens of the slopewash. Strain-vertical stress curves for all of the consolidation tests on upstream and downstream specimens are shown in Appendix $B$.

\section{Consolidation Tests on Downstream Samples}

Nine consolidation tests, four using undisturbed test specimens, were performed on the downstream slopewash material. Tables 3-4 and 3-5 summarize the results of these tests.

The downstream samples were not saturated, and testing them therefore required the use of procedures different from those used for saturated specimens. Many of the specimens were loaded to high pressures before they were flooded, or submerged, and many were never flooded. Moist cotton batting was used to prevent wetting or drying of the specimens that were not flooded. Although the horizontal axes on which the compression test results are plotted are identified as "consolidation pressures", it is important to realize that there were probably significant negative pore pressures (suctions) within these specimens, and the actual 
Table 3-4 Summary of Consolidation Tests on Downstream Sample 36F-1103

\begin{tabular}{|c|c|c|c|c|c|c|c|c|c|c|}
\hline & & & & INITIAL & & & & & & \\
\hline & & & INITIAL & DEGREE & & & & & FINAL & \\
\hline & & & WATER & of & & & & & WATER & \\
\hline TEST & LIQUID & & CONTENT & SATURATION & $\mathrm{Pp}$ & & & & CONTENT & \\
\hline NUMBER* & LIMIT & PI & (\%) & $(\%)$ & $(t s f)$ & OCR & Cac & Cc & $(\%)$ & COMMENTS \\
\hline CON1103\#1S & 40 & 21 & 8 & 56 & $0.6-0.8$ & $1 \cdot 2$ & 0.132 & 0.172 & 19 & $\begin{array}{l}\text { Soaked at } 0.13 \text { tsf. } \\
\text { Sample swelled } 1.6 \% \text {. }\end{array}$ \\
\hline RCON1103\#2 & 40 & 21 & 33 & 100 & $\ldots$. & 1 & 0.124 & 0.184 & 29 & Remolded CON1103\#1S \\
\hline RCON1103\#3 & 40 & 21 & 28 & 98 & $\cdots \cdot$ & 1 & 0.146 & 0.272 & 20 & Remolded CON1103\#1S \\
\hline CON1103\#4 & 41 & 18 & 9 & 52 & $25 \cdot 30$ & $50-60$ & 0.138 & 0.203 & 11 & $\begin{array}{c}\text { Soaked after rebound. } \\
\text { Sample swelled } 5 \% .\end{array}$ \\
\hline
\end{tabular}

* $R=$ Remolded, otherwise Undisturbed

All specimens $2.50 "$ in diameter, $1.00 "$ initial thickness 
Table 3-5 Summary of Consolidation Tests on Downstream Sample 36F-765

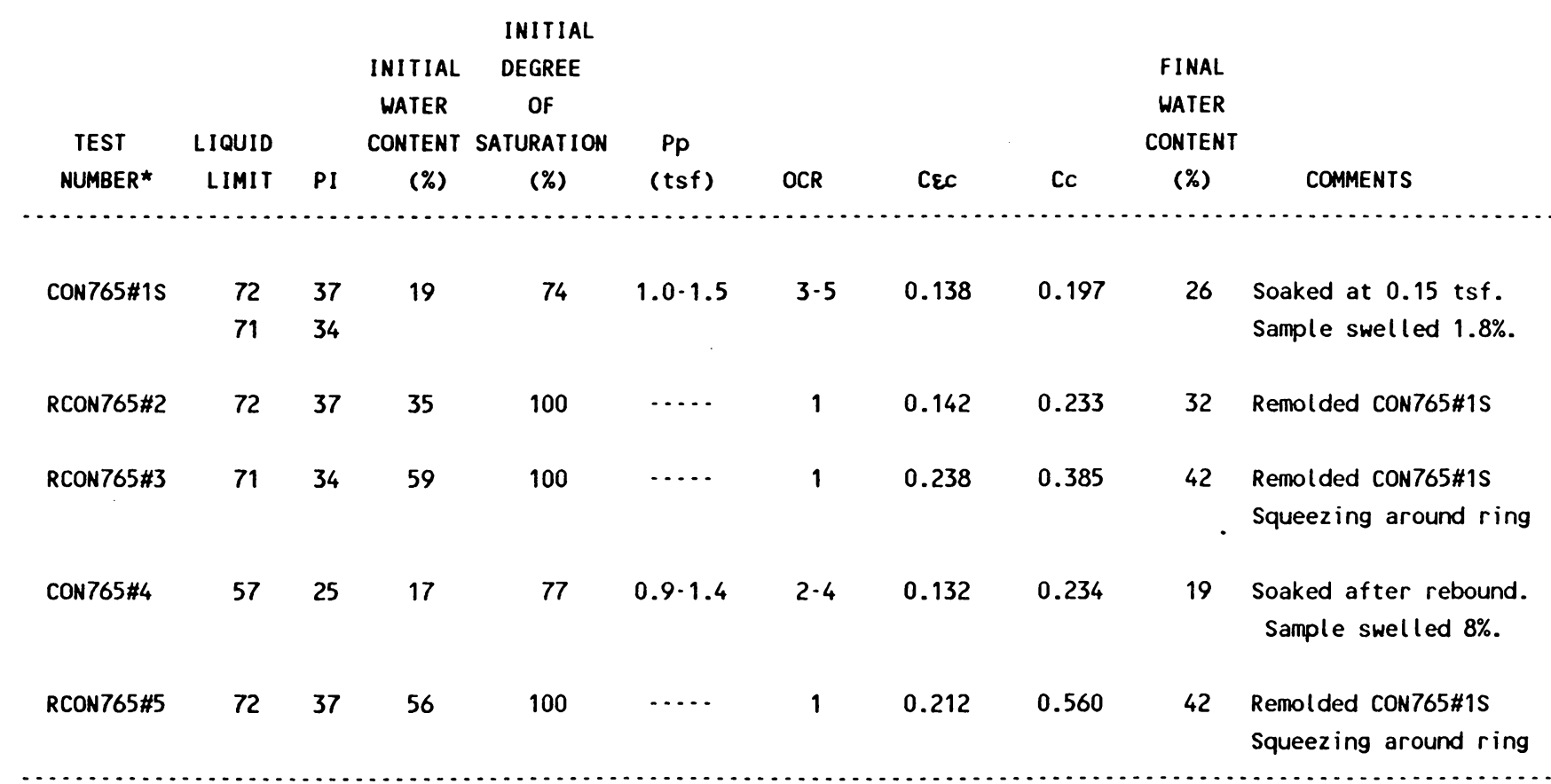

* $R=$ Remolded, otherwise Undisturbed

All specimens 2.50 " diameter, 1.00" initial thickness 
effective stresses may have been larger than indicated on the strain-log pressure plots. In spite of this difference between the flooded and the non-flooded test results, direct comparison of the results is of considerable interest, and provides a basis for some important conclusions regarding the properties and the behavior of the slopewash material, and the effects of desiccation and wetting •

As shown in Figure 3-4, the unsoaked slopewash was extremely stiff due to its desiccated state, and the values of OCR for these specimens were found to be approximately 50 to 60 . As illustrated by the test data shown in Figure 3-4, soaking resulted in considerable swell, followed by an increase in compressibility. The compressibility after soaking was essentially the same as for the remolded material.

As illustrated by the test data shown in Figure 3-5, downstream specimens that were soaked under a small load swelled considerably and subsequently compressed much the same as remolded test specimens, exhibiting only a small preconsolidation pressure. Thus, although the desiccated downstream samples exhibited very high preconsolidation pressures in their natural (unsoaked) states, soaking appeared to erase the effects of preconsolidation and the specimens behaved essentially as if they were normally 


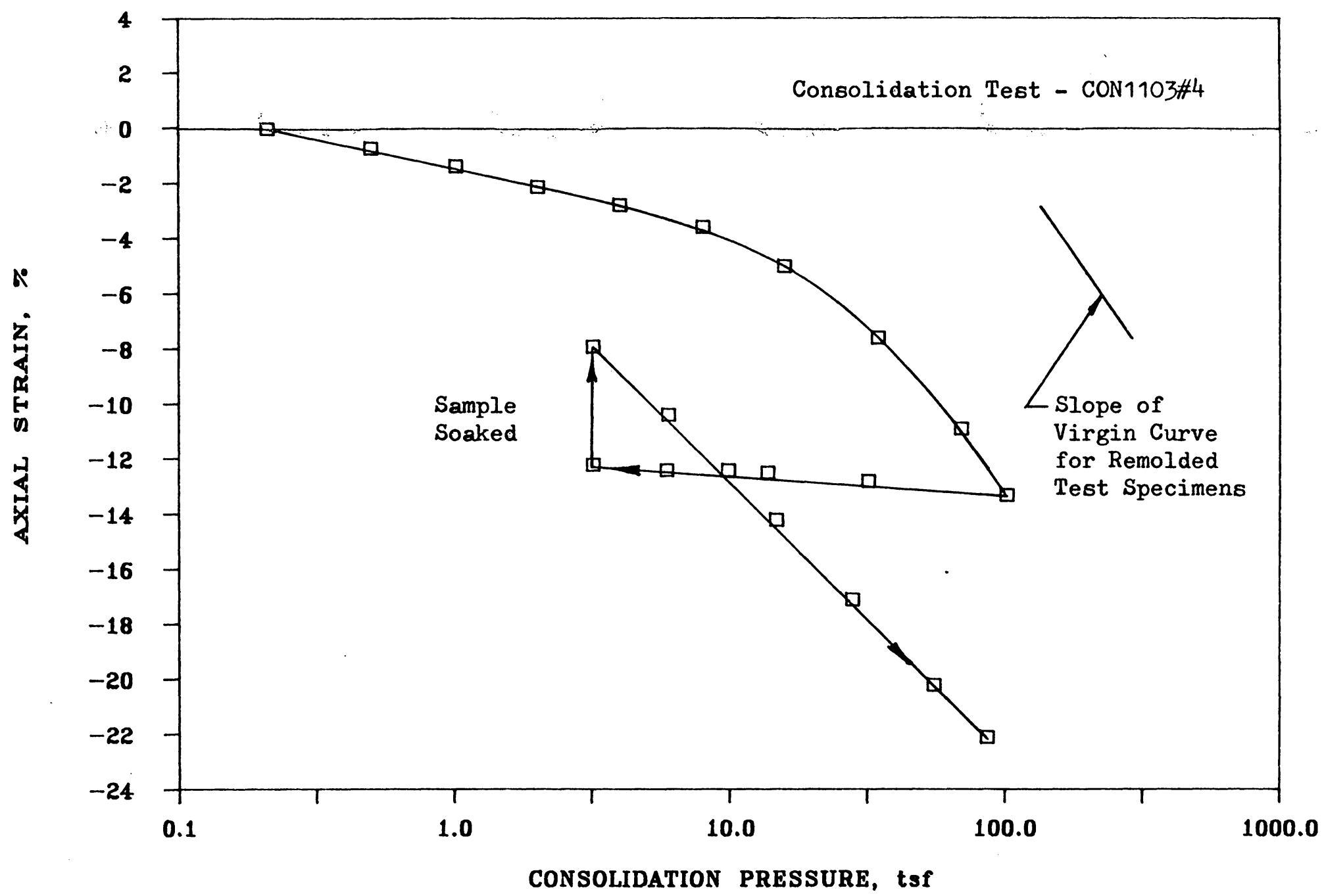

Figure 3-4 Consolidation Test on Unsoaked Downstream Sample 


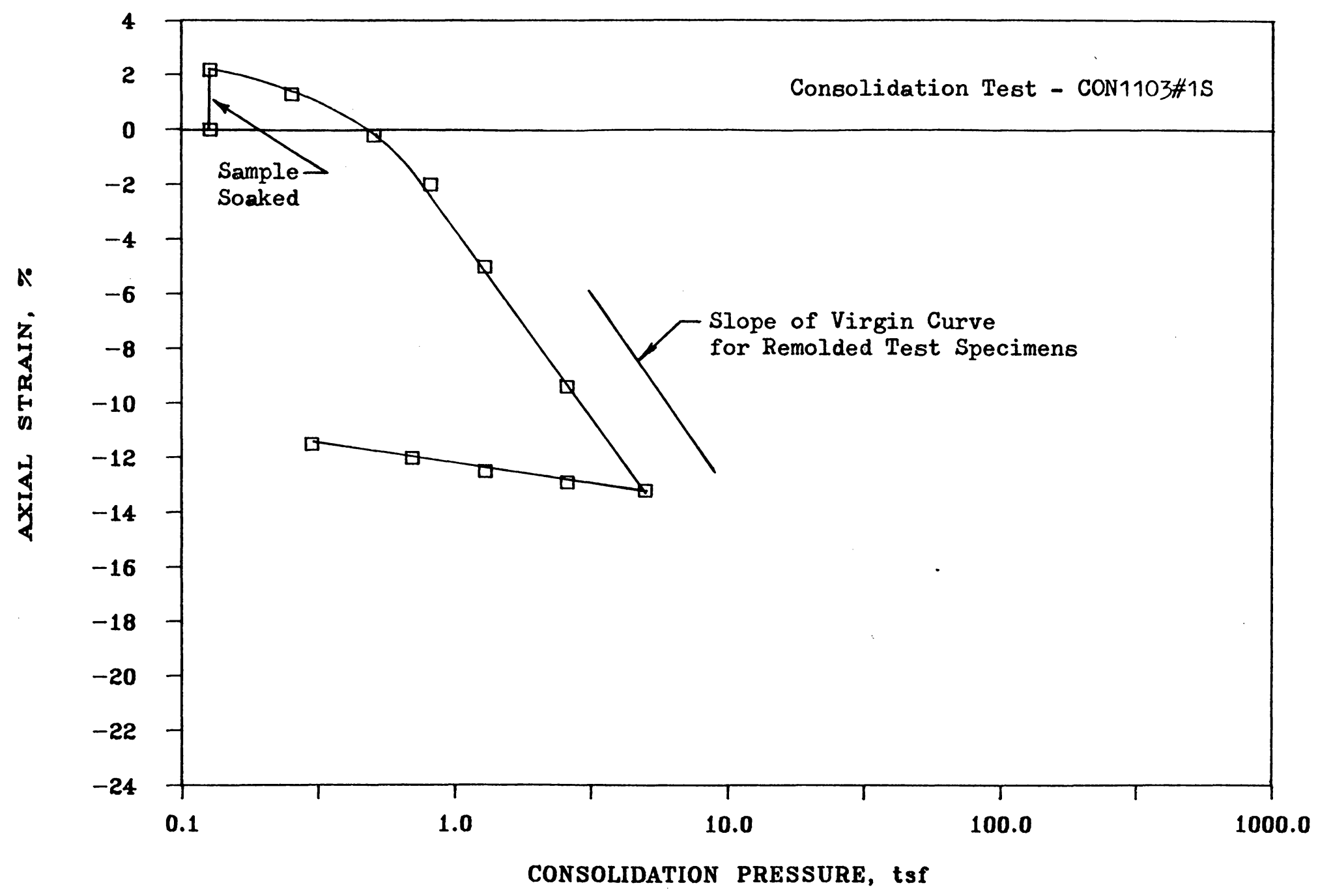

Figure 3-5 Consolidation Test on Soaked Downstream Slopewash Sample 
consolidated after soaking.

\section{Drained Direct Shear Tests}

Before direct shear tests were performed on undisturbed test specimens, a number of direct shear tests were conducted on remolded specimens to determine the optimal sample thickness and strain rate for accurate determination of drained strength parameters. Strengths measured in four of these test are shown in Figure 3-6. Based on these results, it was concluded that a sample thickness of 0.6 to 0.75 inches was suitable for tests on remolded specimens. Specimens 0.8 inches thick were used for tests on undisturbed material. A strain rate of 0.0096 inches per minute was found to be slow enough to ensure fully drained conditions during shear.

\section{Direct Shear Test Procedure}

The direct shear tests were performed using a motorized Wykeham Farrance direct shear apparatus and the procedure described by Lambe (1951). The horizontal and vertical displacements were measured using dial gages and the horizontal force was measured with a load cell.

A typical shear stress-displacement curve for a remolded direct shear sample is shown in Figure 3-7. (Stress-displacement curves for all tests are shown in 


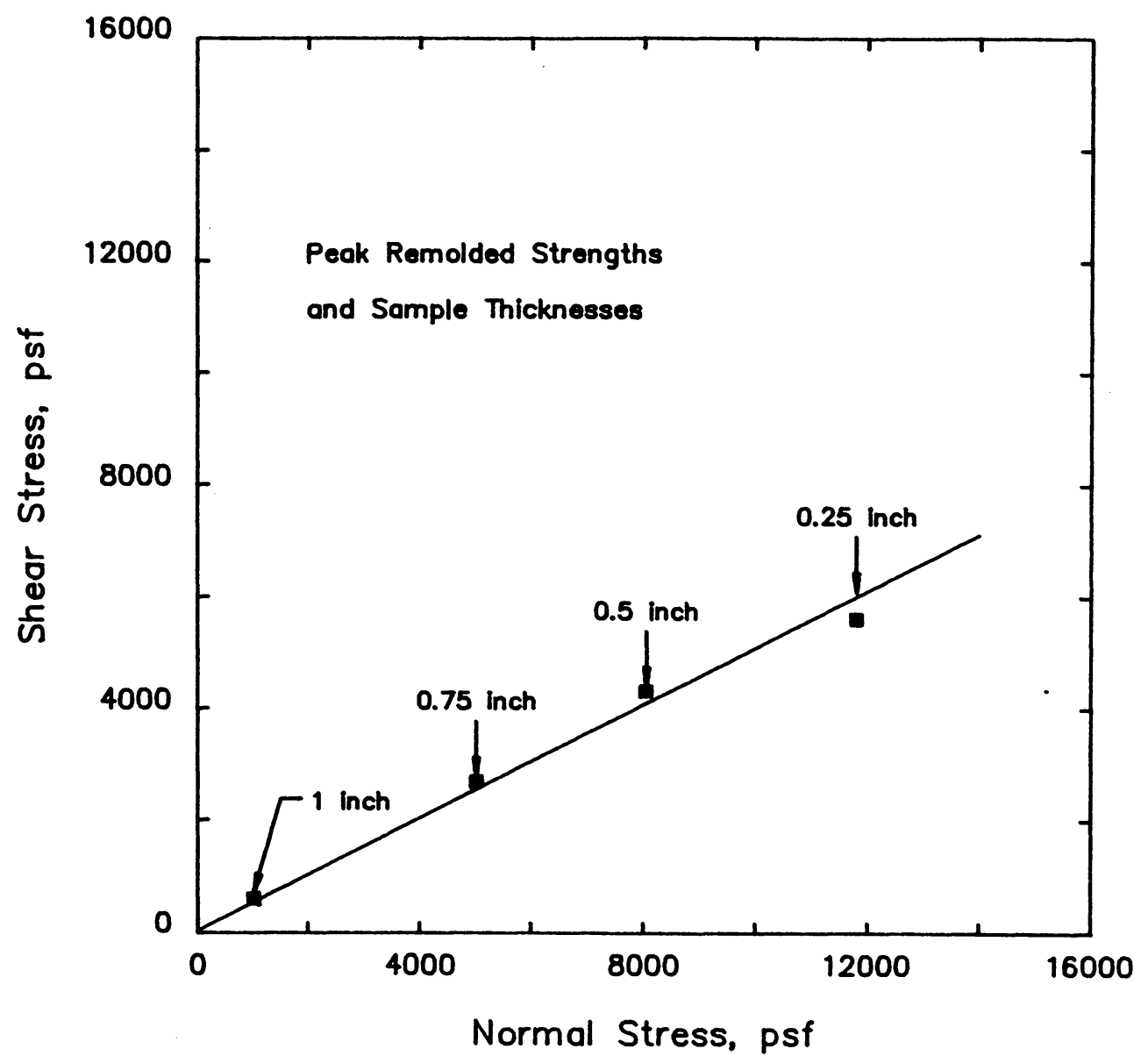

Figure 3-6 Effect of Direct Shear Sample Thickness 

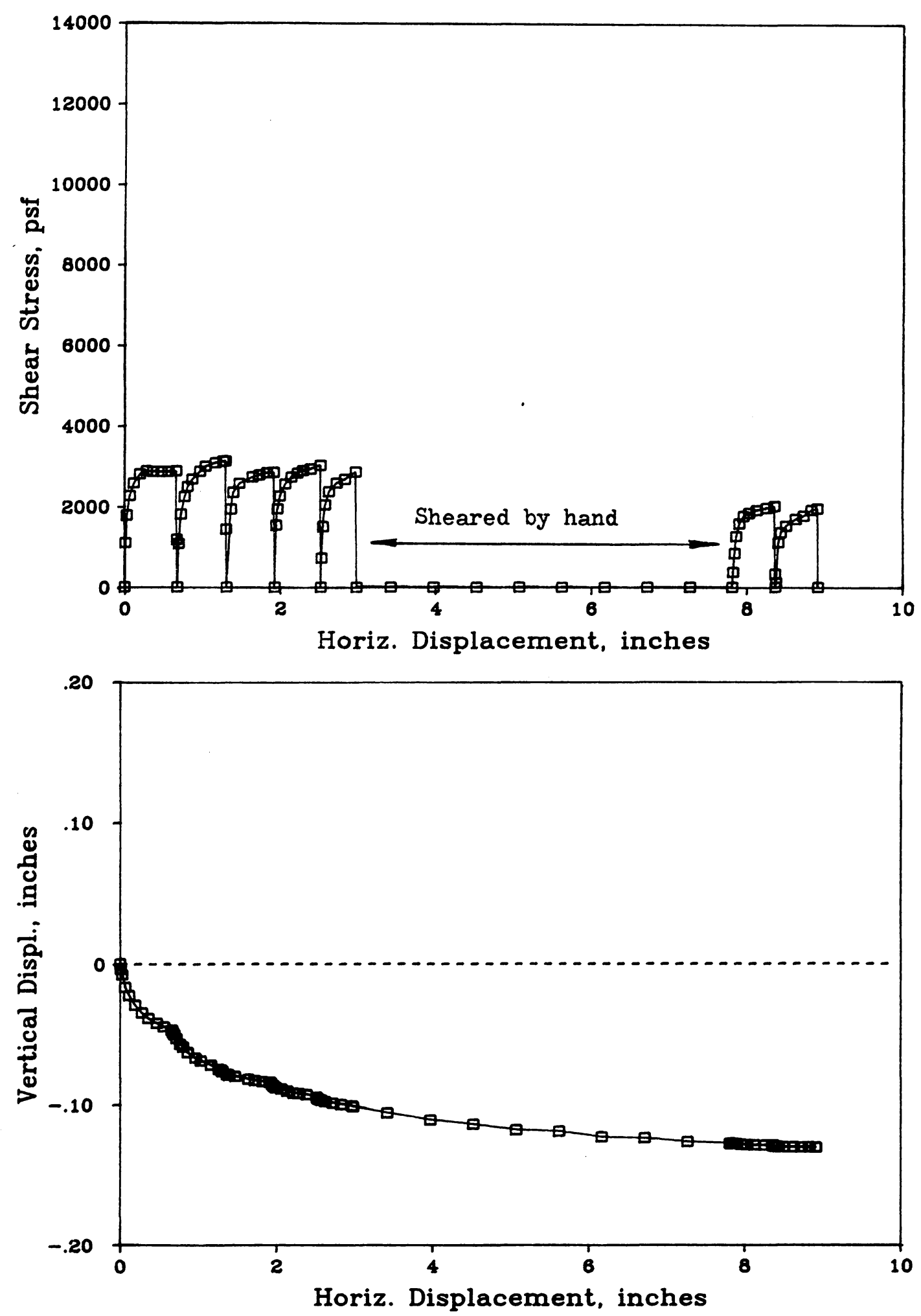

Figure 3-7 Shear Stress-Deformation Curves for Drained Direct Shear Tests on Remolded Slopewash 
Appendix C.) During the test the top half of the shear box, and the test specimen, is displaced horizontally relative to the bottom half. The first travel of the shear box corresponds to the first stress-displacement curve shown in Figure 3-7. At the end of each increment of travel, usually 0.55 inches, the direction of movement of the top half of the shear box was reversed. Successive segments of the stress-displacement curve in Figure 3-7 thus correspond to shear in the opposite direction, forward for the first, third, and fifth segments, and backward for the second, fourth and sixth segments.

At a strain rate of 0.0096 inches per minute, one hour was required for the shear box to complete one increment of travel. Typically it took 8 to 10 inches of horizontal displacement, (i.e. 14 to 18 hours), to reach a residual strength condition. In order to speed up the residual strength tests and to minimize the wear on the direct shear apparatus, the following procedure was adopted:

1) The specimen was sheared two to three inches (four to six increments of travel) at a strain rate of 0.0096 inches per minute.

2) The specimen was then sheared five to six inches (ten to twelve increments of travel) by hand at a strain rate of roughly 0.1 to 1.0 inches per minute. 
3) Excess pore pressures that might have been induced during the rapid shearing were allowed to dissipate for one to three hours.

4) The sample was sheared again at the normal strain rate until a constant residual value of shearing resistance was reached.

Figure 3-7 shows the results of a residual strength test performed using the procedure described above. The shear stress at the end of each travel was reduced to zero and the vertical displacements were recorded. The values of residual strengths obtained using this procedure were in good agreement with residual strength values obtained by cycling the sample back and forth at a slow strain rate. Skempton (1964, 1985) also found that the residual strength was unaffected by the rate of displacement.

The spacing used between the top and bottom halves of the shear box depended on the type of specimen being tested. The remolded specimens were mixed from soil that passed the No. 100 sieve, and a gap of 0.03 inches was used for these specimens. The undisturbed specimens contained numerous rock fragments of varying sizes and a spacing of 0.06 to 0.08 inches was therefore used for tests on undisturbed specimens.

As pointed out by Lambe (1951), sharp increases in shear stress during direct shear tests often indicate that 
the spacing between the top and bottom of the box is not large enough, and that sand grains or rock fragments are being caught between the top and bottom of the shear box. This condition was often observed in the direct shear tests on undisturbed slopewash specimens, as illustrated by the stress-displacement curve for an unsoaked downstream sample in $\mathrm{Figure} 3-8$.

If a test is conducted at a low normal stress and rock fragments are present in the shear plane, the upper part of the shear box may ride up on the rock fragment, producing expansion in sample volume in addition to an increase in shear stress. The test shown in Figure 3-8 was conducted at a normal stress of 6400 psf and it appears that the top of the shear box was riding up on rock fragments when the sample was being pushed away from its initial position and was moving back down as the top of the box was being pulled back toward its initial position. The sharp increases in shear stress and vertical displacement shown in the early part of the test finally decreased at a displacement of roughly seven inches, indicating that the large particles had finally been crushed or dislodged.

\section{Direct Shear Tests on Downstream Samples}

Fifteen direct shear tests, six using undisturbed test specimens, were conducted on the downstream slopewash 

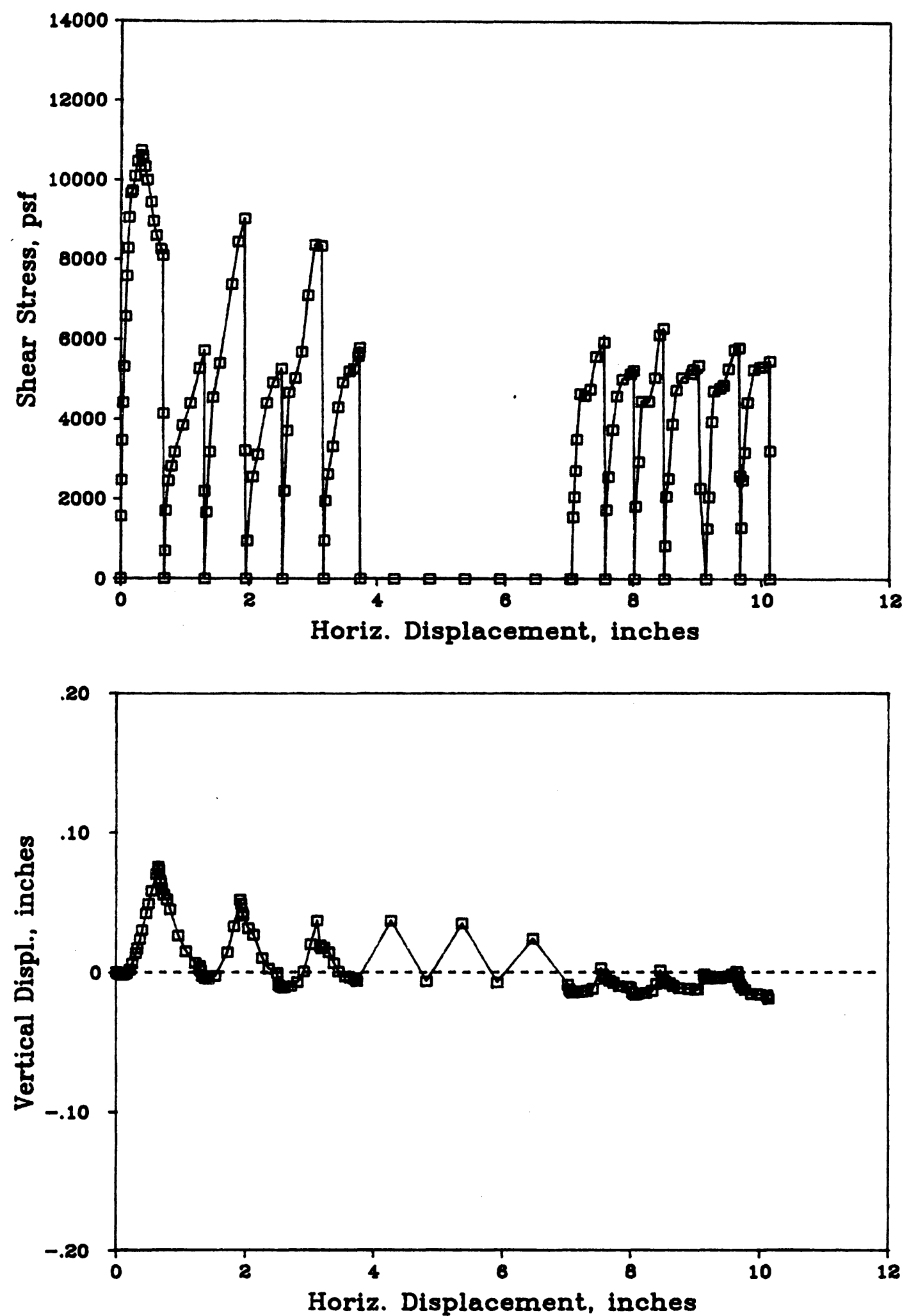

Figure 3-8 Shear Stress-Deformation Curves for Drained Direct Shear Tests on Unsoaked Downstream Slopewash 
material. A summary of these tests is given in Table 3-6. The first three successfully trimmed specimens were sheared without flooding the specimen until after a residual shear stress had been obtained. The unsoaked peak and unsoaked residual strength envelopes determined from these tests are shown in Figure 3-9. The uncharacteristically low peak strength value shown in Figure 3-9 was obtained from the test on the first specimen trimmed using an electric drill and is thought to be erroneous due to disturbance during trimming. After soaking for 1 day, these specimens were sheared again, eventually to a displacement of 8 to 10 inches, to obtain the soaked peak and soaked residual strengths shown in Figure 3-9.

A fourth test, see Figure 3-9, on the undisturbed downstream slopewash material was conducted at a normal stress of 2400 psf to confirm that the erratic peak strength value in the first test conducted at this normal stress was due to disturbance and was not representative. This test was also used to investigate the effect of soaking on the peak strength. The specimen was sheared to a displacement of 0.4 inches to reach the peak shear stress and was then soaked for 40 hours. The shear stressdisplacement curve for this test is shown in Figure 3-10. When the sample was sheared again after soaking its 
Table 3-6 Summary of Direct Shear Tests on Downstream Sample 36F-1103

\begin{tabular}{|c|c|c|c|c|c|c|c|c|c|c|c|c|}
\hline & & & & & DISPLACE- & & & $\begin{array}{l}\text { DISPLACE- } \\
\text { MENT AT }\end{array}$ & & $\begin{array}{l}\text { DISPLACE - } \\
\text { MENT AT }\end{array}$ & & \\
\hline & & & INITIAL & SAMPLE & MENT & & PEAK & PEAK & RESIDUAL & RESIDUAL & FINAL & \\
\hline & & & WATER & THICK- & RATE & NORMAL & SHEAR & SHEAR & SHEAR & SHEAR & WATER & \\
\hline $\begin{array}{c}\text { TEST } \\
\text { NUMBER* }\end{array}$ & LL & PI & $\begin{array}{c}\text { CONTENT } \\
(\%)\end{array}$ & $\begin{array}{c}\text { NESS } \\
\text { (inches) }\end{array}$ & $\begin{array}{l}\text { (inches/ } \\
\text { minute) }\end{array}$ & $\begin{array}{r}\text { STRESS } \\
(p s f)\end{array}$ & $\begin{array}{r}\text { STRESS } \\
(p s f)\end{array}$ & $\begin{array}{l}\text { STRESS } \\
\text { (inches) }\end{array}$ & $\begin{array}{r}\text { STRESS } \\
(p s f)\end{array}$ & $\begin{array}{l}\text { STRESS } \\
\text { (inches) }\end{array}$ & $\begin{array}{c}\text { CONTENT } \\
(\%)\end{array}$ & COMMENTS \\
\hline DS1103\#1S & 36 & 12 & 12 & 0.5 & 0.0032 & 9700 & 3510 & 0.57 & $\cdots$ & $\cdots$ & 17 & $\begin{array}{l}\text { Sample soaked and } \\
\text { disturbed. }\end{array}$ \\
\hline DS1103\#2 & 36 & 11 & 12 & 0.65 & 0.0032 & 9700 & 3690 & 0.06 & $\cdots$ & $\cdots$ & $\cdots$ & $\begin{array}{l}\text { Sample unsoaked and } \\
\text { disturbed. }\end{array}$ \\
\hline DS1103\#2S & 36 & 11 & $\cdots$ & 0.60 & 0.0032 & 9700 & $\cdots$ & $\cdots$ & 2690 & 6.97 & $\cdots$ & Soaked \\
\hline DS1103\#2S & 36 & 11 & $\ldots$ & 0.59 & 0.0032 & 6515 & $\cdots$ & $\ldots$ & 1780 & 3.21 & $\ldots$ & Soaked \\
\hline DS1103\#2S & 36 & 11 & $\cdots$ & 0.56 & 0.0032 & 3145 & $\cdots$ & $\cdots$ & 930 & 6.22 & 27 & Soaked \\
\hline RDS1103\#3 & 36 & 12 & 37 & 0.75 & 0.0048 & 6505 & 2680 & 0.53 & $\ldots$ & $\cdots$ & $\ldots$ & $\begin{array}{l}\text { Remolded } \\
\text { DS1103\#1S }\end{array}$ \\
\hline RDS1103\#4 & 36 & 12 & 37 & 0.70 & 0.0048 & 3530 & 1550 & 0.53 & $\cdots$ & $\cdots$ & 17 & $\begin{array}{l}\text { Remolded } \\
\text { DS1103\#1S }\end{array}$ \\
\hline
\end{tabular}

$* R=$ Remolded, otherwise Undisturbed

All specimens 4.00 inches square 
Table 3-6 Continued

\begin{tabular}{|c|c|c|c|c|c|c|c|c|c|c|c|c|}
\hline & & & & & DISPLACE - & & & $\begin{array}{l}\text { DISPLACE- } \\
\text { MENT AT }\end{array}$ & & $\begin{array}{l}\text { DISPLACE- } \\
\text { MENT AT }\end{array}$ & & \\
\hline & & & INITIAL & SAMPLE & MENT & & PEAK & PEAK & RESIDUAL & RESIDUAL & FINAL & \\
\hline & & & WATER & THICK- & RATE & NORMAL & SHEAR & SHEAR & SHEAR & SHEAR & WATER & \\
\hline TEST & & & CONTENT & NESS & (inches/ & STRESS & STRESS & STRESS & STRESS & STRESS & CONTENT & \\
\hline NUMBER* & LL & PI & $(\%)$ & (inches) & minute) & $(p s f)$ & $(p s f)$ & (inches) & $(p s f)$ & (inches) & $(\%)$ & COMMENTS \\
\hline DS1103\#5 & 33 & 14 & 9 & 1.00 & 0.0019 & 3200 & 4025 & 0.44 & 3100 & 9.17 & … & Unsoaked Peak \& Residual \\
\hline DS1103\#5S & 33 & 14 & $\cdots$ & 0.81 & 0.0048 & 3200 & 1650 & 0.48 & 1050 & 9.51 & 14 & Soaked Peak \& Residual \\
\hline DS1103\#6 & 36 & 15 & 7 & 0.79 & 0.0048 & 9600 & 13190 & 0.31 & 8075 & $9: 18$ & $\cdots$ & Unsoaked Peak \& Residual \\
\hline DS1103\#6S & 36 & 15 & $\cdots$ & 0.72 & 0.0096 & 9600 & 4050 & 0.26 & 2700 & 9.11 & 15 & Soaked Peak \& Residual \\
\hline DS1103\#7 & 39 & 20 & 8 & 0.79 & 0.0048 & 6400 & 10670 & 0.31 & 5406 & 10.52 & $\cdots$ & Unsoaked Peak \& Residual \\
\hline DS1103\#7S & 39 & 20 & $\cdots$ & 0.74 & 0.0096 & 6400 & 2950 & 0.66 & 1940 & 8.81 & 11 & Soaked Peak \& Residual \\
\hline DS1103\#8 & 38 & 16 & 9 & 0.72 & 0.0096 & 2385 & 7290 & 0.29 & $\cdots$ & $\cdots$ & $\cdots$ & Unsoaked Peak \\
\hline DS1103\#8S & 38 & 16 & $\cdots$ & 0.61 & 0.0096 & 2385 & 995 & 1.29 & 700 & 7.24 & 22 & Soaked Peak \& Residual \\
\hline
\end{tabular}

* $R=$ Remolded, otherwise Undisturbed

All specimens 4.00 inches square 


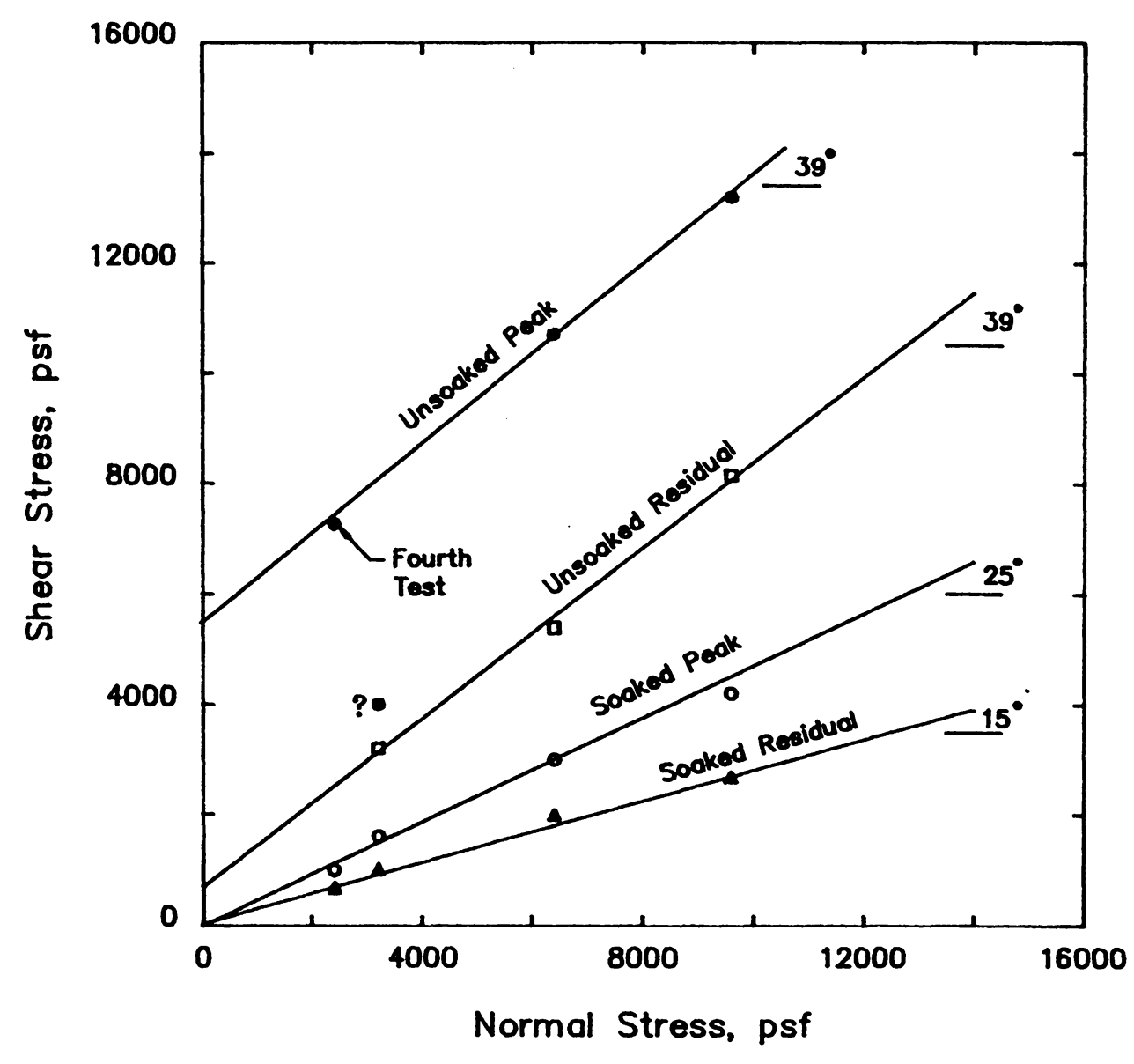

$\stackrel{\Delta}{\Delta}$

Figure 3-9 Direct Shear Tests on Downstream Slopewash 

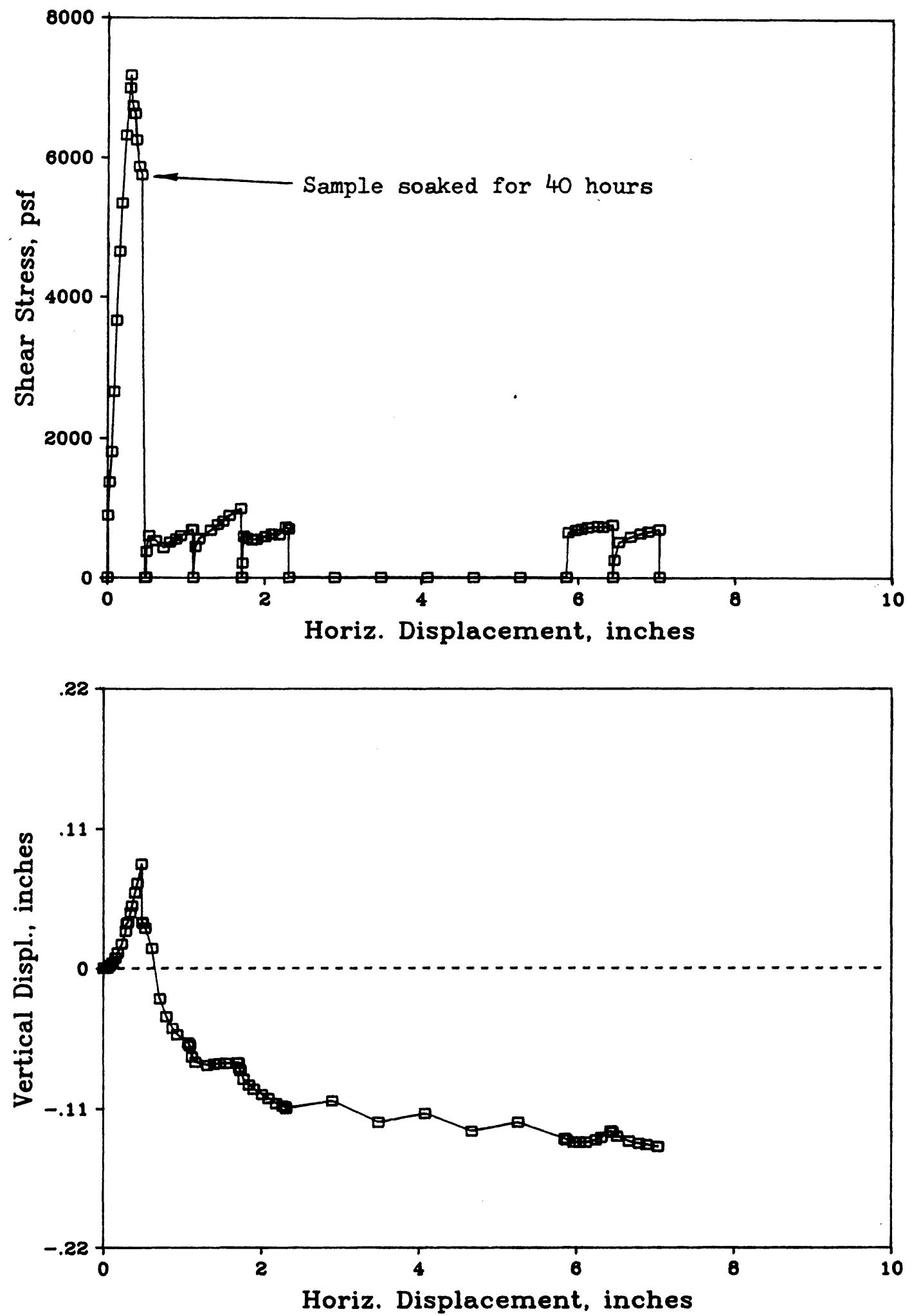

Figure 3-10 Effect of Soaking on Downstream Slopewash in Direct Shear 
shearing resistance had dropped from the unsoaked peak value, 7300 psf, to the soaked peak envelope, 1100 psf, as shown in Figure $3-10$.

The strength loss upon soaking shown by the results in Figure 3-9 is quite remarkable. Upon soaking, the peak strength of the desiccated slopewash material decreased immediately to a value considerably below the unsoaked residual strength. With continued shear displacement, the samples suffered a further drop in shearing resistance to the soaked residual value.

Peak and residual strengths obtained from tests on remolded specimens are plotted in Figure 3-1l with the peak strengths for unsoaked and soaked undisturbed downstream specimens. As shown, the remolded peak strengths are the same as those for the soaked undisturbed specimens. Similarly, the residual strength values are also the same for the remolded and the soaked undisturbed specimens. Thus it can be seen that the shear strength of the highly desiccated slopewash material decreases to the remolded (or fully softened) value as soon as the material is soaked. Thus soaking immediately destroys the effects of desiccation by removing essentially all of the suction and/or particle cementation present in the natural slopewash. Upon soaking the slopewash reverts to the fully softened strength, exhibiting no lasting effect of having 


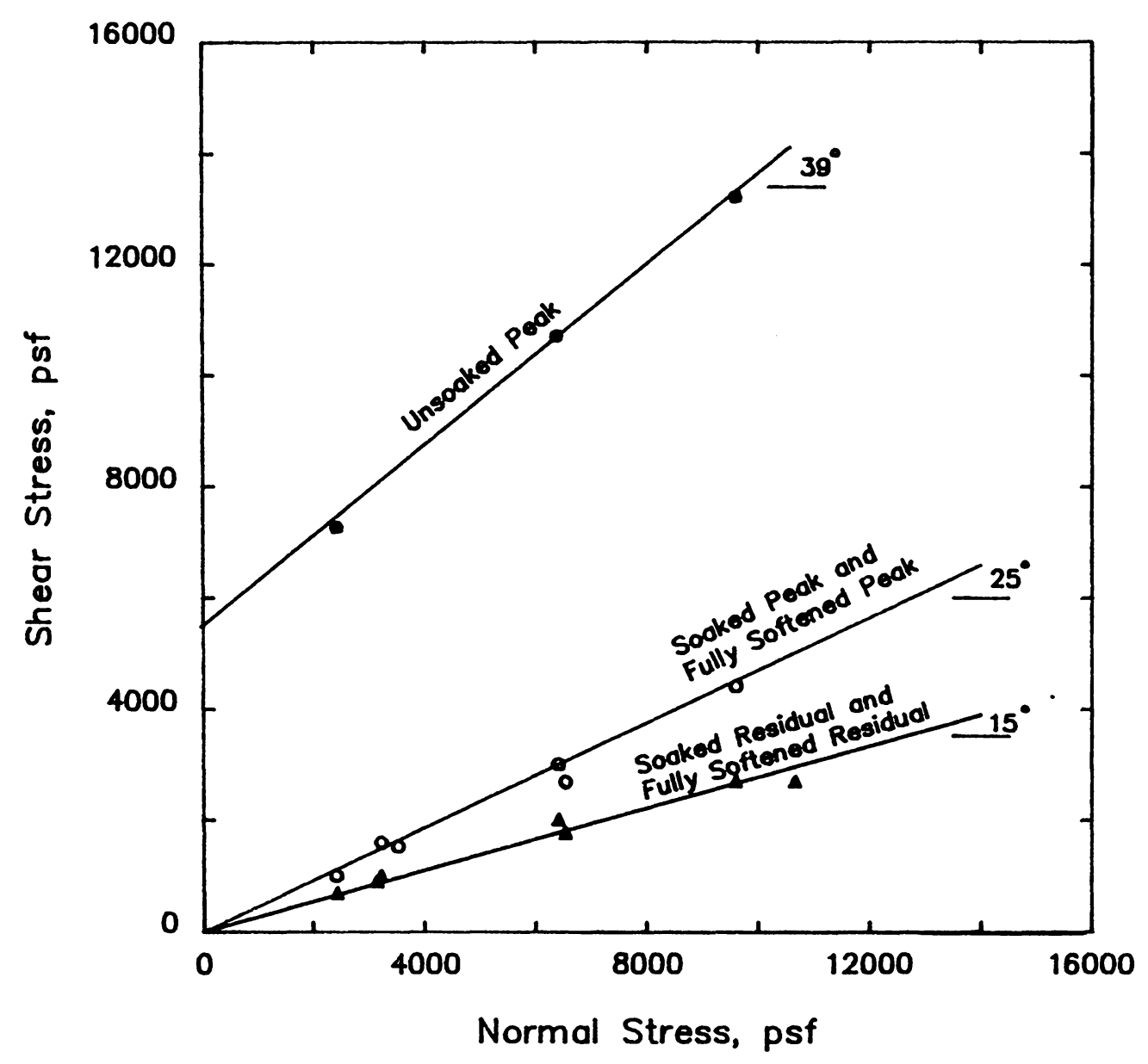

Figure 3-11 Downstream Slopewash Failure Envelopes 
been overconsolidated by desiccation.

\section{Direct Shear Tests on Opstream Samples}

Eighteen direct shear tests, seven using undisturbed test specimens, were conducted on the upstream slopewash material. Tables $3-7$ and 3-8 provide a summary of these tests.

The drained failure envelopes shown in Figure 3-12 indicate that the undisturbed and remolded samples have very similar peak strengths. Only for normal stresses smaller than 4000 psf was the undisturbed peak strength larger than the remolded peak, and even then the difference was small. The residual strengths were obtained after 8 to 10 inches of displacement had accumulated, by which time the shearing resistance had decreased to a stable minimum value. As shown in Figure 3-12, the residual shearing resistance was the same for undisturbed and remolded specimens.

In summary, soaking of the desiccated slopewash in the laboratory or the field appears to destroy the effects of desiccation, and the slopewash reverts to the fully softened strength, exhibiting no lasting effect of having been overconsolidated by desiccation. This behavior is quite different from that exhibited by mechanically overconsolidated clays (Skempton, 1964). To explore the 
Table 3-7 Summary of Direct Shear Tests on Upstream Sample 36F-1101

\begin{tabular}{|c|c|c|c|c|c|c|c|c|c|c|c|c|}
\hline $\begin{array}{l}\text { TEST } \\
\text { NUMBER* }\end{array}$ & LL & PI & $\begin{array}{c}\text { INITIAL } \\
\text { WATER } \\
\text { CONTENT } \\
(\%)\end{array}$ & $\begin{array}{l}\text { SAMPLE } \\
\text { THICK- } \\
\text { NESS } \\
\text { (inches) }\end{array}$ & $\begin{array}{l}\text { DISPLACE- } \\
\text { MENT } \\
\text { RATE } \\
\text { (inches/ } \\
\text { minute) }\end{array}$ & $\begin{array}{r}\text { NORMAL } \\
\text { STRESS } \\
(p s f)\end{array}$ & $\begin{array}{c}\text { PEAK } \\
\text { SHEAR } \\
\text { STRESS } \\
\text { (psf) }\end{array}$ & $\begin{array}{l}\text { DISPLACE- } \\
\text { MENT AT } \\
\text { PEAK } \\
\text { SHEAR } \\
\text { STRESS } \\
\text { (inches) }\end{array}$ & $\begin{array}{c} \\
\text { RESIDUAL } \\
\text { SHEAR } \\
\text { STESS } \\
\text { (psf) }\end{array}$ & $\begin{array}{l}\text { DISPLACE- } \\
\text { MENT AT } \\
\text { RESIDUAL } \\
\text { SHEAR } \\
\text { STRESS } \\
\text { (inches) }\end{array}$ & $\begin{array}{c}\text { FINAL } \\
\text { HATER } \\
\text { CONIENT } \\
(\%)\end{array}$ & COMMENTS \\
\hline DS1101\#1S & 40 & 20 & 19 & 1.0 & 0.00096 & 3200 & 1750 & 0.42 & $\cdots$ & $\cdots \cdot$ & 20 & $\begin{array}{l}\text { First four } \\
\text { soaked }\end{array}$ \\
\hline DS1101\#2S & 41 & 21 & 21 & 1.0 & 0.00096 & 800 & 750 & 0.31 & $\cdots$ & $\cdots$ & 20 & $\begin{array}{l}\text { tests to } \\
\text { establish }\end{array}$ \\
\hline DS1101\#3S & 38 & 26 & 21 & 1.0 & 0.00096 & 9610 & 5000 & 0.33 & $\cdots$ & $\cdots$ & 19 & $\begin{array}{l}\text { dislace- } \\
\text { ment rates. }\end{array}$ \\
\hline DS1101\#4S & 38 & 26 & 21 & 0.5 & 0.00096 & 9610 & 4960 & 0.35 & $\cdots$ & $\cdots$ & 20 & \\
\hline RDS1101\#5 & 40 & 20 & 36 & 1.0 & 0.00096 & 1000 & 520 & 0.52 & $\cdots$ & $\cdots$ & 28 & $\begin{array}{c}\text { Four } \\
\text { Remolded }\end{array}$ \\
\hline RDS1101\#6 & 40 & 20 & 26 & 0.75 & 0.00096 & 5000 & 2650 & 0.61 & $\cdots$ & $\cdots$ & 21 & $\begin{array}{l}\text { tests to } \\
\text { establish }\end{array}$ \\
\hline RDS1101\#7 & 40 & 20 & 32 & 0.5 & 0.00096 & 8050 & 4240 & 0.55 & $\cdots$ & $\cdots$ & 21 & $\begin{array}{l}\text { sample } \\
\text { height. }\end{array}$ \\
\hline RDS1101\#8 & 40 & 20 & 35 & 0.5 & 0.0096 & 11760 & 5690 & 0.67 & $\cdots$ & $\cdots$ & 17 & \\
\hline DS1101\#9 & 39 & 17 & 20 & 0.80 & 0.0096 & 1790 & 1210 & 0.30 & $\cdots$ & $\cdots$ & $\cdots$ & Unsoaked Peak \\
\hline DS1101\#9S & 39 & 17 & $\cdots$ & 0.75 & 0.0096 & 1790 & $\cdots$ & $\cdots$ & 670 & 9.06 & $\cdots$ & Soaked Residual \\
\hline DS1101\#9S & 39 & 17 & $\cdots$ & 0.70 & 0.0096 & 4006 & $\cdots$ & $\cdots$ & 1510 & 8.41 & $\cdots$ & Soaked Residual \\
\hline DS1101\#9S & 39 & 17 & $\cdots$ & 0.60 & 0.0096 & 6011 & $\cdots$ & $\cdots$ & 2050 & 9.81 & 26 & Soaked Residual \\
\hline DSC1101\#2S & $\cdots$ & $\cdots$ & 18 & 0.79 & 0.0096 & 11140 & 5800 & 0.29 & $\cdots$ & $\cdots \cdot$ & 18 & $\begin{array}{c}\text { Second Cyclic Direct } \\
\text { Shear Test }\end{array}$ \\
\hline
\end{tabular}

* $R=$ Remolded, otherwise Undisturbed

All specimens 4.00 inches square 
Table 3-8 Summary of Direct Shear Tests on Upstream Sample 36F-1102

\begin{tabular}{|c|c|c|c|c|c|c|c|c|c|c|c|c|}
\hline $\begin{array}{l}\text { TEST } \\
\text { NUMBER* }\end{array}$ & $\mathrm{LL}$ & PI & $\begin{array}{c}\text { INITIAL } \\
\text { WATER } \\
\text { CONTENT } \\
(\%)\end{array}$ & $\begin{array}{l}\text { SAMPLE } \\
\text { THICK- } \\
\text { NESS } \\
\text { (inches) }\end{array}$ & $\begin{array}{l}\text { DISPLACE- } \\
\text { MENT } \\
\text { RATE } \\
\text { (inches/ } \\
\text { minute) }\end{array}$ & $\begin{array}{r}\text { NORMAL } \\
\text { STRESS } \\
\text { (psf) }\end{array}$ & $\begin{array}{c}\text { PEAK } \\
\text { SHEAR } \\
\text { STRESS } \\
\text { (psf) }\end{array}$ & $\begin{array}{l}\text { DISPLACE- } \\
\text { MENT AT } \\
\text { PEAK } \\
\text { SHEAR } \\
\text { STRESS } \\
\text { (inches) }\end{array}$ & $\begin{array}{c}\text { RESIDUAL } \\
\text { SHEAR } \\
\text { STRESS } \\
\text { (psf) }\end{array}$ & $\begin{array}{l}\text { DISPLACE- } \\
\text { MENT AT } \\
\text { RESIDUAL } \\
\text { SHEAR } \\
\text { STRESS } \\
\text { (inches) }\end{array}$ & $\begin{array}{c}\text { FINAL } \\
\text { WATER } \\
\text { CONTENT } \\
(\%)\end{array}$ & COMMENTS \\
\hline DS1102\#1 & 44 & 19 & 21 & 0.79 & 0.0048 & 175 & 350 & 0.35 & $\cdots$ & $\cdots$ & $\cdots$ & Unsoaked \\
\hline DS1102\#1S & 44 & 19 & $\cdots$ & 0.75 & 0.0048 & 5505 & $\cdots$ & $\cdots$ & 2500 & 7.08 & $\cdots$ & Soaked Residual \\
\hline DS1102\#1S & 44 & 19 & $\cdots$ & 0.67 & 0.0048 & 11100 & $\cdots$ & $\cdots$ & 4590? & $7: 00$ & $\cdots$ & $\begin{array}{l}\text { Soaked Residual } \\
\text { (Test rerun) }\end{array}$ \\
\hline DS1102\#1S & 44 & 19 & $\cdots$ & 0.64 & 0.0096 & 11100 & $\cdots$ & $\cdots$ & 3950 & 4.35 & $\cdots$ & Soaked Residual \\
\hline DS1102\#1S & 44 & 19 & $\cdots$ & 0.60 & 0.0096 & 8505 & $\cdots$ & $\cdots$ & 2480 & 6.73 & 26 & Soaked Residual \\
\hline
\end{tabular}

* $R=$ Remolded, otherwise Undisturbed

All specimens 4.00 inches square 


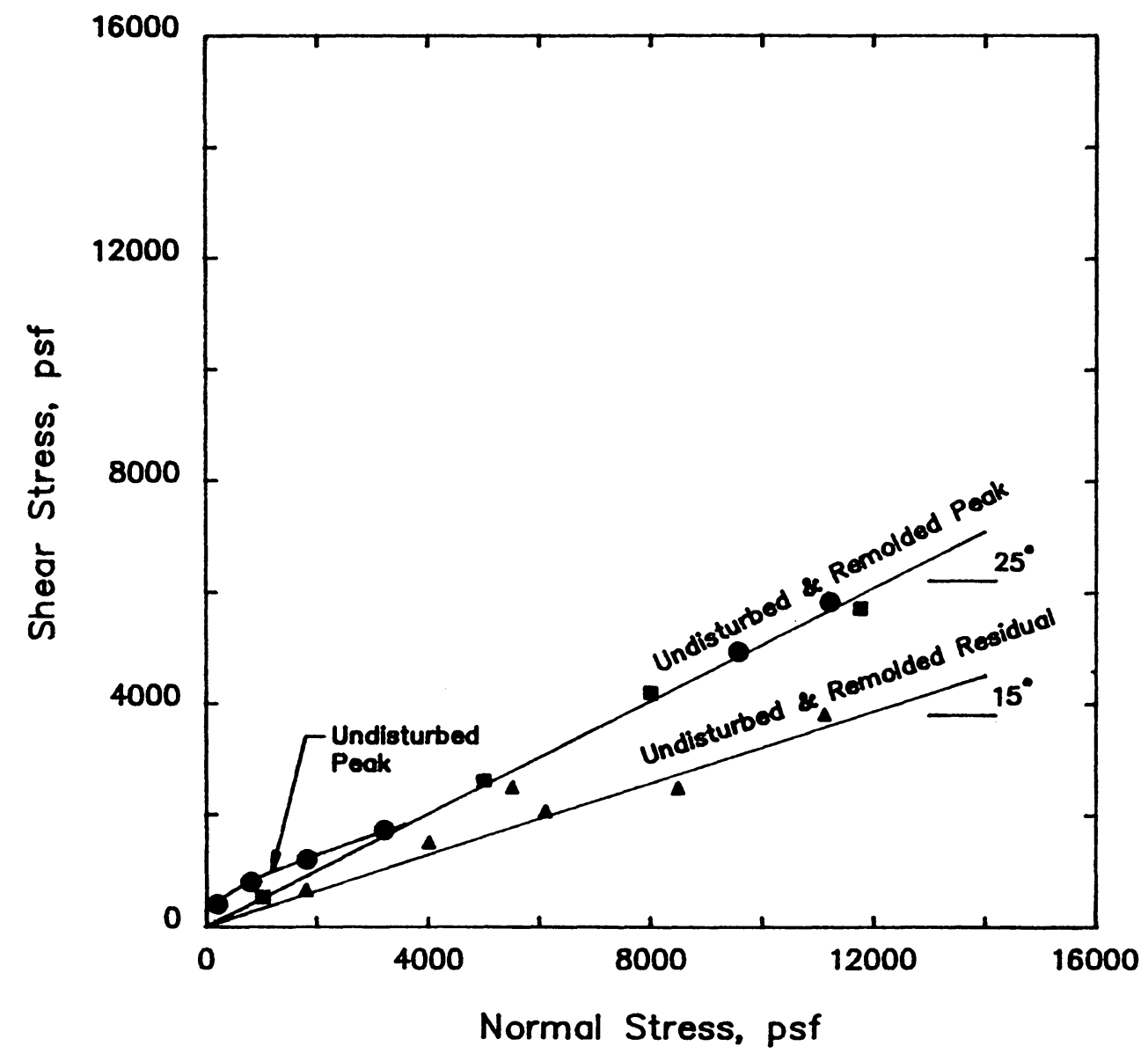

Figure 3-12 Upstream Slopewash Failure Envelopes 
difference in behavior between samples overconsolidated by desiccation and samples overconsolidated by applied pressure (mechanically overconsolidated) the tests described in the following sections were performed.

\section{Strength of Mechanically overconsolidated Specimens}

Four remolded specimens were consolidated to the same void ratio as the undisturbed desiccated slopewash under a consolidation pressure of 11 tsf. These tests are summarized in Table 3-9. The results of these tests highlighted four differences between the behavior of samples overconsolidated by desiccation and external pressures.

As shown in Figure $3-13$, the peak strengths of the remolded specimens were much lower than the peak strengths of the dry undisturbed specimens, even though they were consolidated to the same void ratio. In addition, the strengths of the mechanically overconsolidated specimens were unaffected by soaking, while the strengths of the dry desiccated sample were reduced to the fully softened condition upon soaking.

A horizontal displacement of about six-tenths of an inch was required to reduce the strength of the mechanically overconsolidated specimens at normal stresses of 2400 and 6400 psf to their fully softened peak strength 
Table 3-9 Summary of Mechanically Overconsolidated Direct Shear Tests

\begin{tabular}{|c|c|c|c|c|c|c|c|c|c|c|c|c|}
\hline & & & & & DISPLACE - & & & $\begin{array}{l}\text { DISPLACE- } \\
\text { MENT AT }\end{array}$ & & $\begin{array}{l}\text { DISPLACE- } \\
\text { MENT AT }\end{array}$ & & \\
\hline & & & INITIAL & SAMPLE & MENT & & PEAK & PEAK & RESIDUAL & PEAK & FINAL & \\
\hline & & & WATER & THICK- & RATE & NORMAL & SHEAR & SHEAR & SHEAR & SHEAR & WATER & \\
\hline TEST & & & CONTENT & NESS & (inches/ & STRESS & STRESS & STRESS & STRESS & STRESS & CONTENT & \\
\hline NUMBER & LL & PI & $(\%)$ & (inches) & minute) & $(p s f)$ & $(p s f)$ & (inches) & (psf) & (inches) & $(\%)$ & COMMENTS \\
\hline OCDS\#1 & 38 & 16 & 34 & 0.80 & 0.0096 & 2400 & 2170 & 0.29 & 800 & 17.08 & 24 & Remolded DS1103\#8 \\
\hline OCDS\#2 & 39 & 20 & 38 & 1.27 & 0.0096 & 6400 & 4050 & 0.24 & 1700 & 7.61 & 22 & Remolded DS1103\#7 \\
\hline OCDS\#3 & 36 & 15 & 37 & 1.10 & 0.0096 & 13930 & 5500 & 0.37 & 4000 & 7.43 & 19 & Remolded DS1103\#6 \\
\hline OCDS\#4 & 36 & 15 & 33 & 0.95 & 0.0096 & 10720 & 4800 & 0.38 & $\cdots$ & $\cdots$ & 20 & Remolded DS1103\#6 \\
\hline
\end{tabular}

All specimens are remolded downstream Slopewash \& 4.00 inches square. 


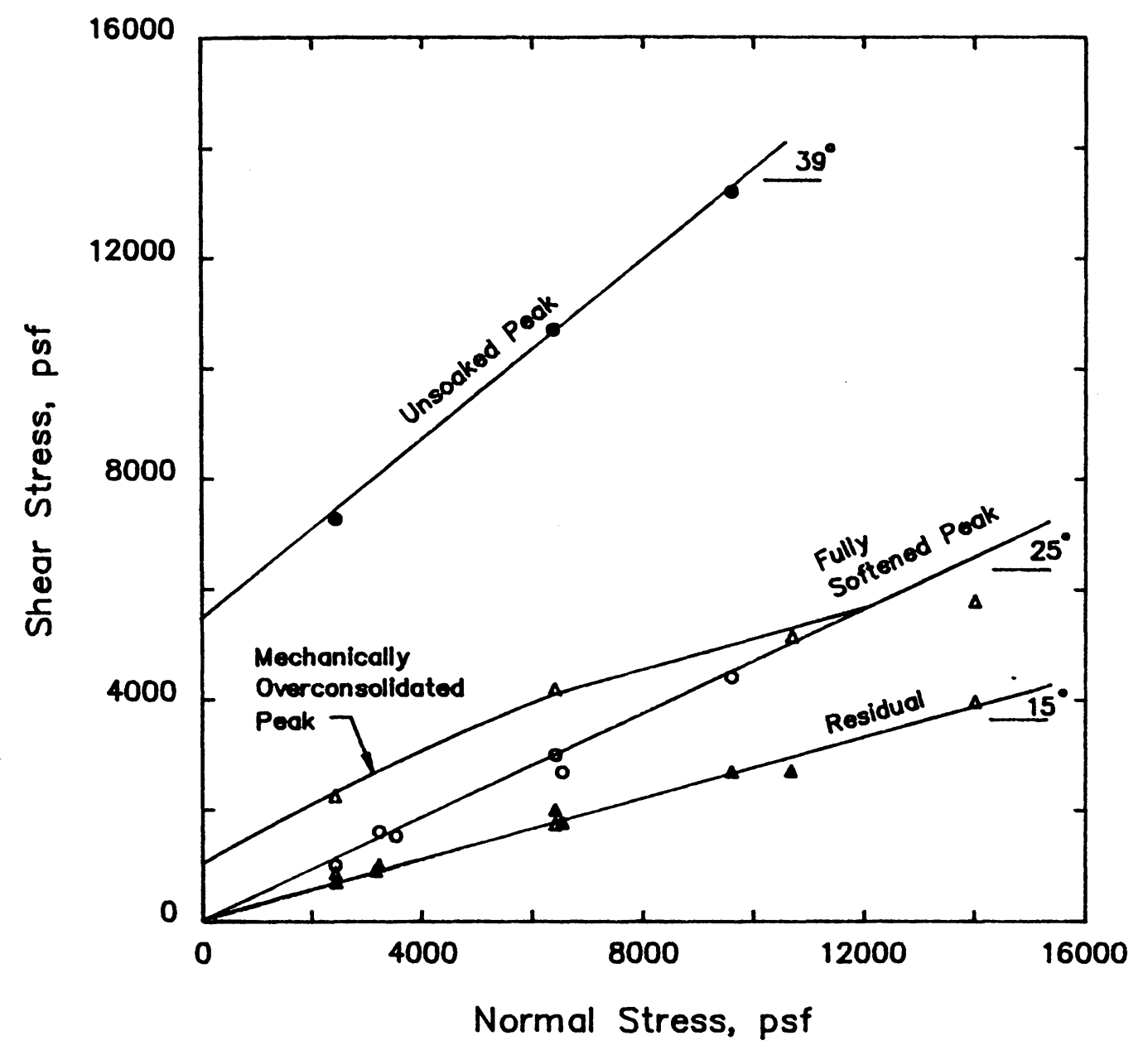

Figure 3-13 Direct Shear Tests on Mechanically Overconsolidated Slopewash 
values, as shown in Figure 3-14. Conversely, the desiccated samples underwent a much larger strength loss upon soaking, and did not require any displacement to reach the fully softened condition.

Finally, the time required for mechanically overconsolidated clays to reach a fully softened condition is much larger than for desiccated clays. Skempton (1970, 1977) has reported a number of case histories of stiff fissured clays in which the time required for a fully softened condition to develop varied from 16 to 80 years. Skempton also suggested that stiff intact clays may never reach a fully softened condition. In contrast, it seems likely that the strength of the desiccated slopewash in the foundation of San Luis Dam was reduced to its fully softened condition within days or weeks after the reservoir filled.

Studies by Delage and Lefebvre (1984) indicated that specimens consolidated by desiccation have a denser microstructure than samples that are consolidated to similar void ratios by external loads. This difference in structure may be responsible for the very different strength behavior of mechanically overconsolidated and desiccated samples.

Thus it is clear that mechanical overconsolidation and desiccation produce materials with very different modes of 


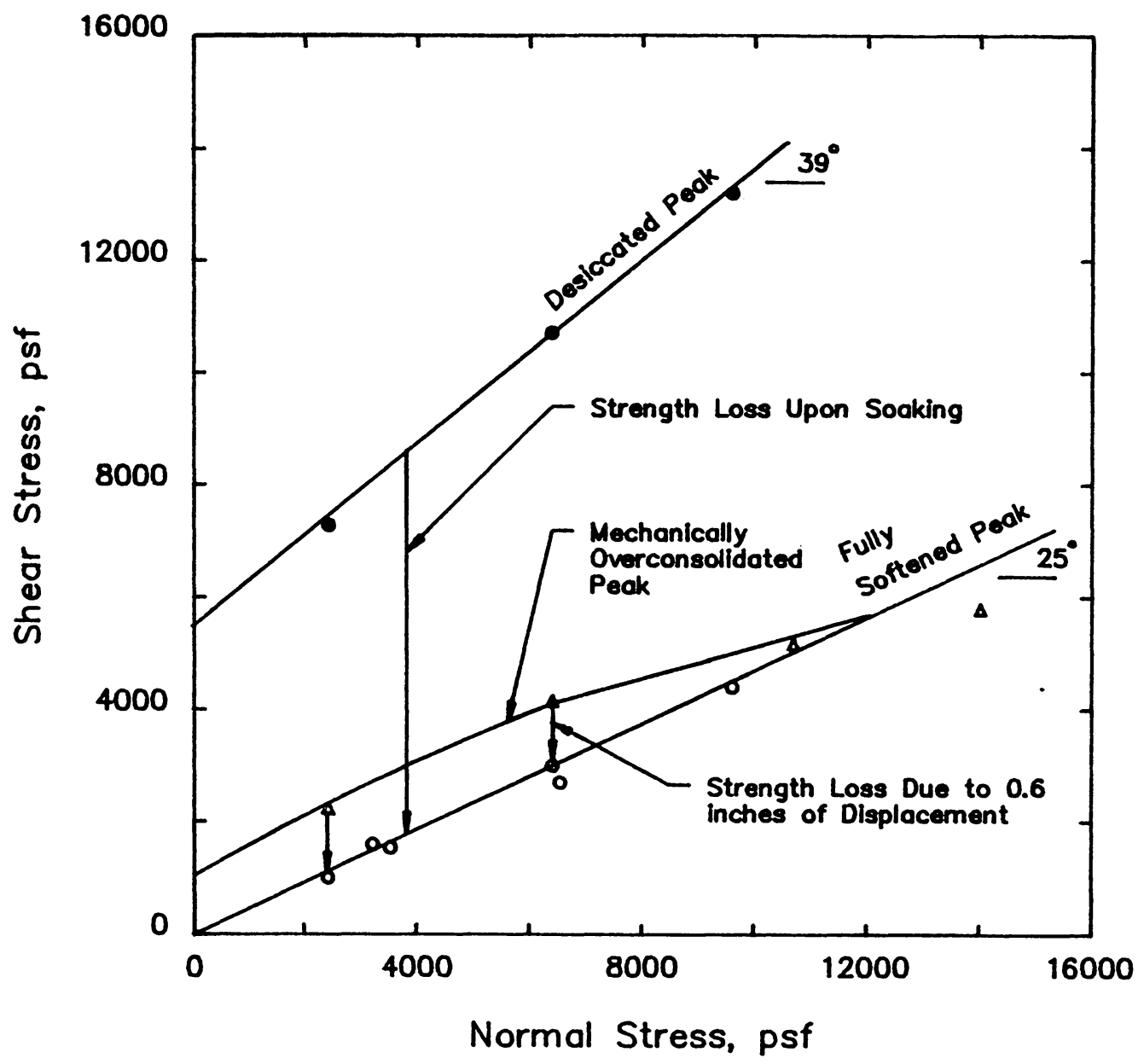

Figure 3-14 Comparison of Overconsolidation by Desiccation and External Pressure 
behavior. Peak strengths developed through mechanical overconsolidation are not as great as those developed through desiccation. However, strengths developed through mechanical consolidation are more persistent. All or most of the strength developed by desiccation disappears as soon as the material is soaked.

\section{Tests on Downstream Block Sample $36 \mathrm{~F}-765$}

During their investigation of the 1981 slide, the Bureau of Reclamation tested samples with a range of Atterberg limit values, as shown in Figure 3-1. The tests discussed previously were all performed on specimens of the grey slopewash, which was less plastic than the red slopewash, as discussed previously and shown in Table 3-1. Only a partial block (36F-765) containing the red slopewash was available for testing.

Five consolidation tests, summarized in Table 3-5, and one direct shear test, summarized in Table 3-10, were performed on specimens of the red slopewash. Due to its higher plasticity, it showed a greater tendency to swell and to slake when wetted. The red clay had a higher compressibility than the grey slopewash, as shown in Table 3-1. It also had a lower peak unsoaked shear strength than the grey slopewash, as shown in Figure 3-15. However, upon soaking the strength of the red slopewash was reduced to 
Table 3-10 Summary of Direct Shear Test on Downstream Sample 36F-765

\begin{tabular}{|c|c|c|c|c|c|c|c|c|c|c|c|c|}
\hline $\begin{array}{c}\text { TEST } \\
\text { NUMBER* }\end{array}$ & LL & PI & $\begin{array}{c}\text { INITIAL } \\
\text { WATER } \\
\text { CONTENT } \\
(\%)\end{array}$ & $\begin{array}{l}\text { SAMPLE } \\
\text { THICK- } \\
\text { NESS } \\
\text { (inches) }\end{array}$ & $\begin{array}{l}\text { DISPLACE- } \\
\text { MENT } \\
\text { RATE } \\
\text { (inches/ } \\
\text { minute) }\end{array}$ & $\begin{array}{r}\text { NORMAL } \\
\text { STRESS } \\
\text { (psf) }\end{array}$ & $\begin{array}{c}\text { PEAK } \\
\text { SHEAR } \\
\text { STRESS } \\
(p s f)\end{array}$ & $\begin{array}{l}\text { DISPLACE- } \\
\text { MENT AT } \\
\text { PEAK } \\
\text { SHEAR } \\
\text { STRESS } \\
\text { (inches) }\end{array}$ & $\begin{array}{c}\text { RESIDUAL } \\
\text { SHEAR } \\
\text { STRESS } \\
\text { (psf) }\end{array}$ & $\begin{array}{l}\text { DISPLACE- } \\
\text { MENT AT } \\
\text { RESIDUAL } \\
\text { SHEAR } \\
\text { STRESS } \\
\text { (inches) }\end{array}$ & $\begin{array}{c}\text { FINAL } \\
\text { WATER } \\
\text { CONTENT } \\
(\%)\end{array}$ & COMMENTS \\
\hline DS765\#1 & 68 & 31 & 19 & 0.79 & 0.0096 & 2405 & 4310 & 0.25 & $\cdots$ & $\cdots$ & $\cdots$ & $\begin{array}{l}\text { Red Slopewash } \\
\text { Unsoaked Peak }\end{array}$ \\
\hline DS765\#1S & 68 & 31 & $\cdots$ & 0.73 & 0.0096 & 2405 & 1145 & 0.52 & 790 & 10.27 & 30 & $\begin{array}{c}\text { Soaked Peak \& } \\
\text { Residual }\end{array}$ \\
\hline
\end{tabular}

* $R=$ Remolded, otherwise Undisturbed

All specimens 4.00 inches square 


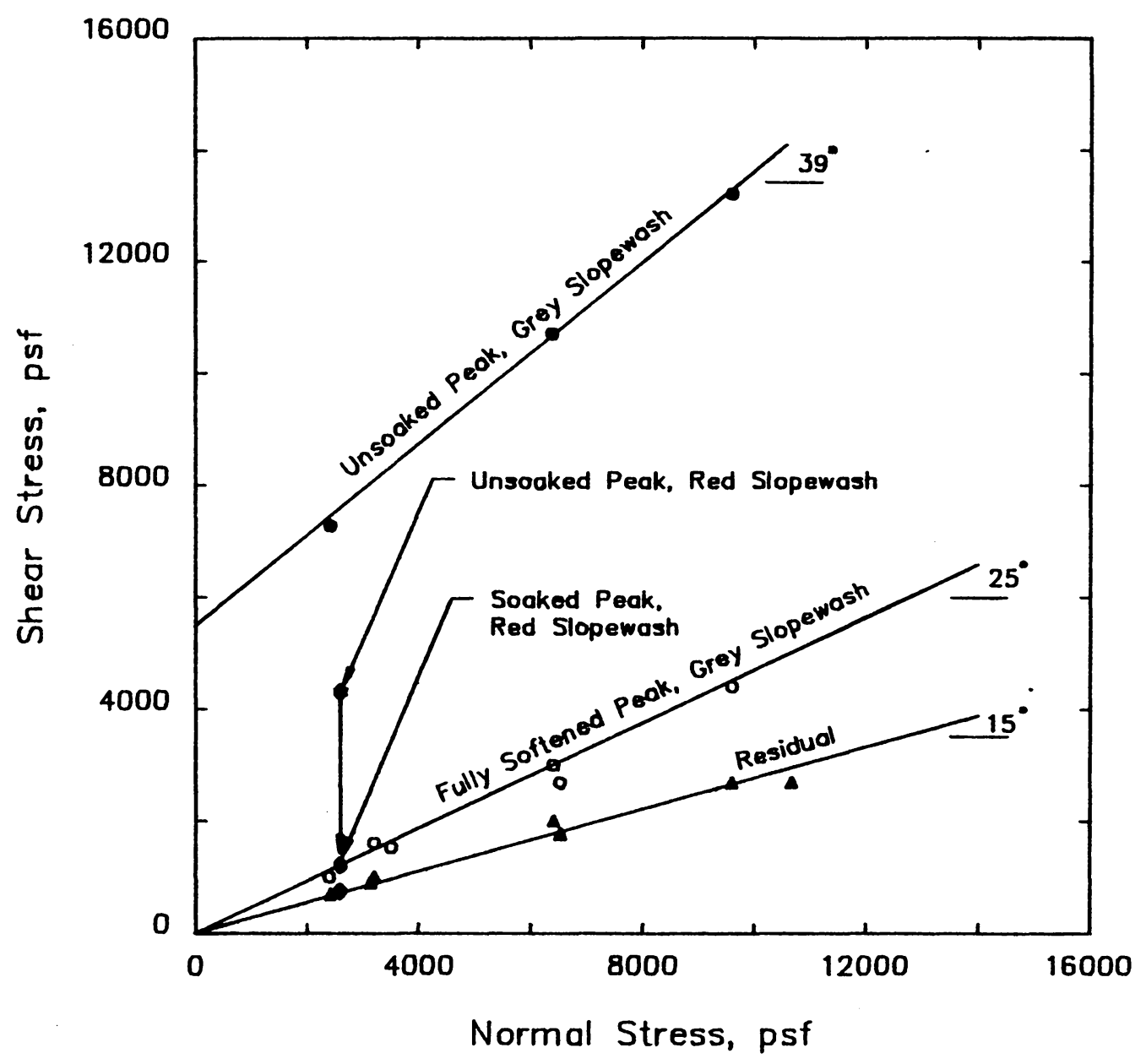

Figure 3-15 Comparison of Direct Shear Test on Red Slopewash with Results for Grey Slopewash 
essentially the same peak strength as the grey slopewash, as shown in Figure 3-15. The red and grey slopewash samples also had similar residual strengths.

\section{Ud Triaxial Tests}

Four unconsolidated-undrained (UU) triaxial tests were performed on upstream samples of the slopewash to determine its undrained stress-strain and strength characteristics for use in slope stability and finite element analyses. The stress-strain curves for these tests are shown in Figure 3-16 and the UU failure envelope is shown in Figure 3-17. The degrees of saturation of the four samples varied from 668 to $98 \%$, the average being 838 . Since the samples were not fully saturated, the total stress friction angle is greater than zero.

\section{CO Triaxial Tests}

Three consolidated-undrained (CU) triaxial tests with pore pressure measurements were performed on upstream samples of the slopewash to determine the effective stressstrain and strength characteristics for use in slope stability and finite element analyses. The stress-strain and pore pressure-strain curves for these tests are shown in Figure 3-18. The effective stress failure envelope from the $\mathrm{CU}$ tests is shown in Figure 3-19. It may be seen that 


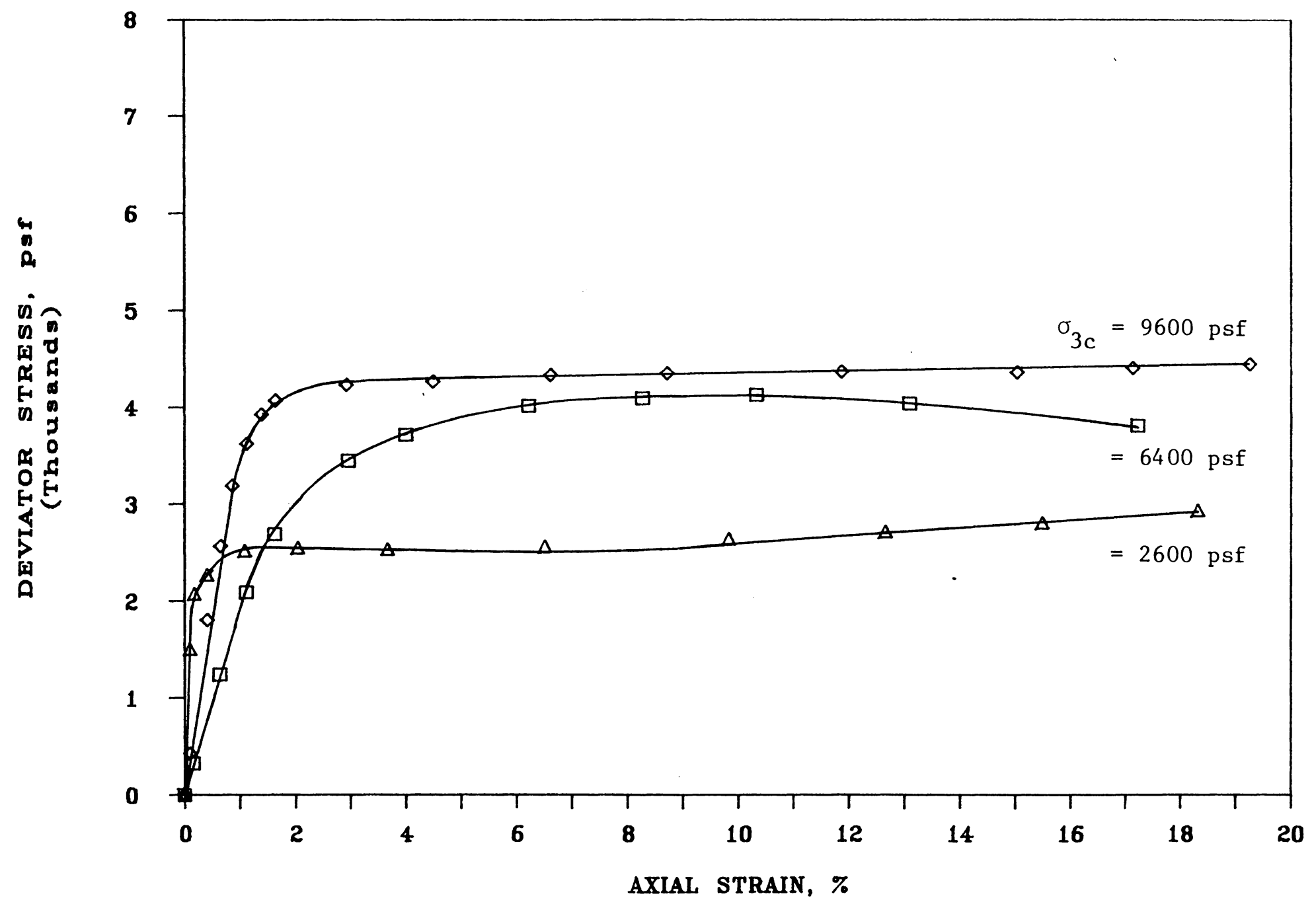

운

Figure 3-16 Stress-Strain Curves for UU Triaxial Tests on Upstream Slopewash Samples 


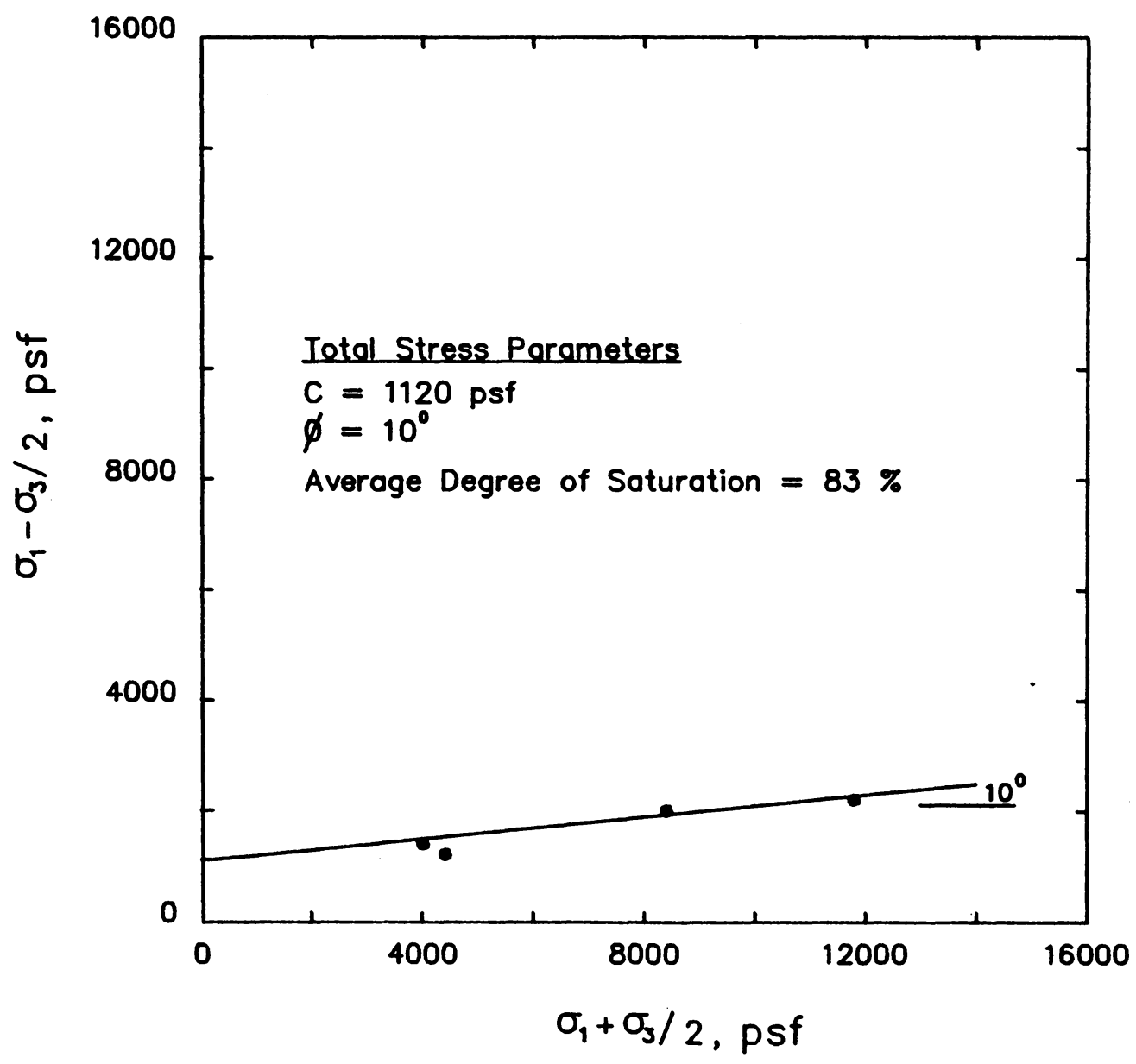

Figure 3-17 UU Triaxial Tests on Upstream Slopewash 

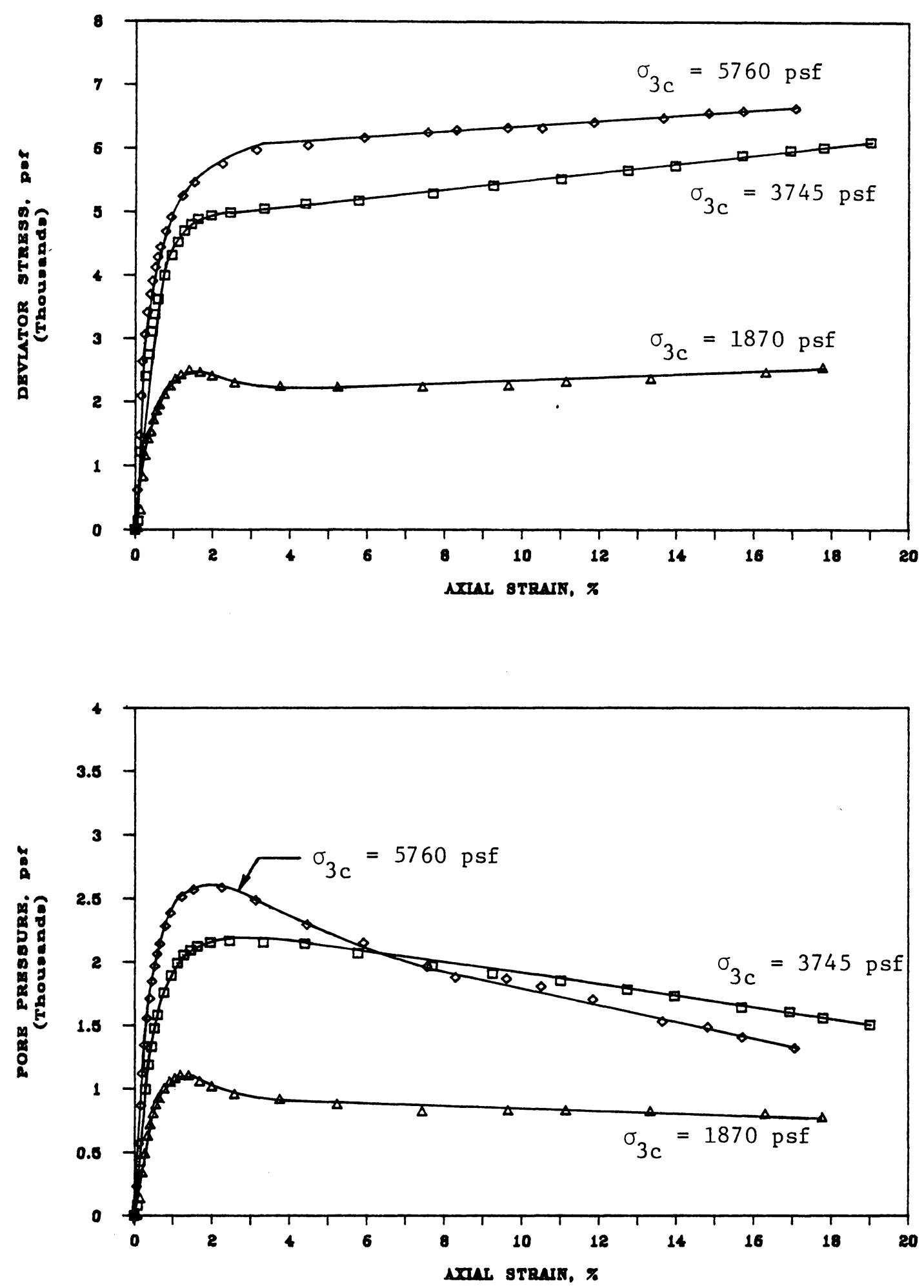

Figure 3-18 Stress-Strain and Pore Pressure-Strain Curves for CU Triaxial Tests on Upstream Slopewash Samples 


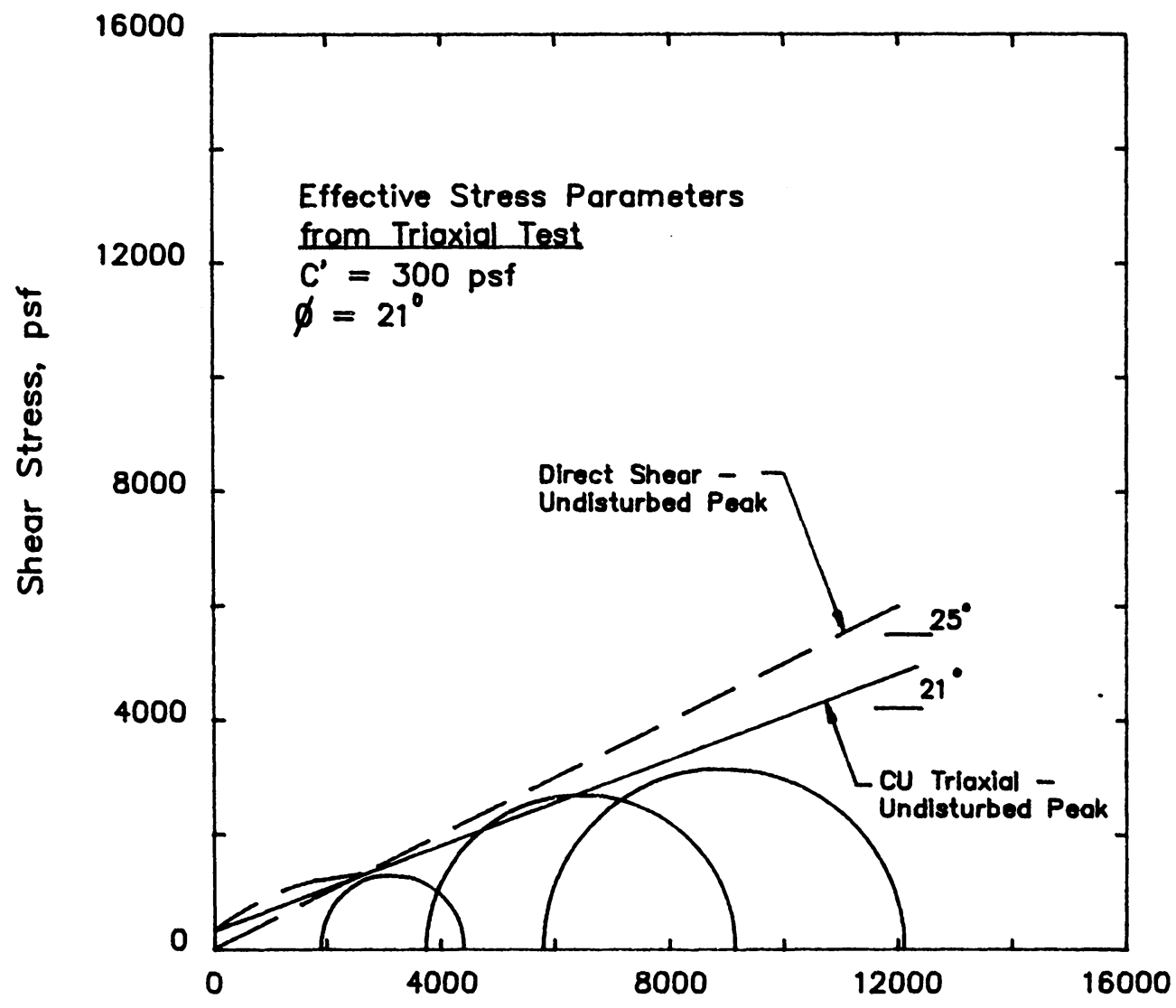

Figure 3-19 Effective Stress-Strength Envelope from CU Triaxial Tests on Upstream Slopewash 
the effective stress strength envelope from the triaxial tests is in quite close agreement with the peak strength envelope from direct shear tests.

\section{Súmmary}

Table 3-11 summarizes the shear strength parameters determined from the direct shear tests on the upstream and downstream samples of the slopewash.

The total and effective shear strength parameters from UU and CU triaxial tests are also shown in Table 3-11.

Soaking of the desiccated slopewash material resulted in essentially a complete loss of the suction and/or particle cementation resulting from desiccation. After soaking, the slopewash behaved as a slightly overconsolidated material, with a shear strength corresponding very closely to the fully softened condition.

The peak shear strength of mechanically overconsolidated samples at the same void ratio, although much lower than the strength of desiccated specimens, was unaffected by soaking. Studies by Delage and Lefebvre (1984) show desiccation produces a denser microstructure than mechanical overconsolidation. This difference in structure may explain the very different strength behavior of mechanically consolidated and desiccated specimens. 
TABLE 3-11 - Summary of Strength Parameters for Upstream and Downstream Slopewash

Material

\section{Upstream Slopewash}

Direct Shear Peak Undisturbed

Direct Shear Peak Remolded

(Fully Softened)

Direct Shear Residual

CU Triaxial

UU Triaxial

\section{Downstream Slopewash}

Direct Shear Peak Undisturbed (Unsoaked)

Direct Shear Residual Undisturbed 700 (Unsoaked)

Direct Shear Peak Undisturbed (Soaked)

Direct Shear Peak Remolded (Fully Softened)

Residual Undisturbed \& Remolded (Soaked)

$\begin{array}{cccc}C^{\prime} & C & \phi^{\prime} & \varnothing \\ (\text { psf }) & (\text { psf }) & (0) & (0)\end{array}$

0

26

0

26

0

15

300

21

1120 
The grey slopewash samples exhibit a larger strength before soaking than the red slopewash, but both have the same peak strength after soaking, and both have the same residual strength. 


\section{CHAPTER FOUR - Analysis of Time Lag in Pore Pressures During Drawdown}

\section{Introduction}

Piezometers installed in the slopewash beneath the upstream slope of San Luis Dam after the 1981 slide showed that changes in the pore pressures in the slopewash did not keep pace with changes in reservoịr level during episodes of rapid drawdown. After the reservoir was drawn down completely, some excess pore pressures remained in the slopewash, and these dissipated with time, eventually reaching equilibrium with the reservoir level.

These measurements indicated that there would have been excess pore pressures in the slopewash during the 1981 slide, which followed a period of rapid drawdown. However, since the slopewash piezometers were installed after the slide, measured pore pressures at the time of the slide were not available.

The analyses described in this chapter were performed to estimate the excess pore pressures at the time of the 1981 slide. This was accomplished using finite element analyses of the transient seepage during the drawdown cycles preceding the slide. The finite element model was calibrated using field data obtained from piezometer measurements made after the slide.

The finite element analyses also provided estimates of 
the pore pressures in the Zone 1 material at the time of the slide, which were also needed for stability analyses. In addition, the analyses indicated the rate of progression of the phreatic surface through the dam during the first years of operation of the reservoir.

\section{Geologic Conditions}

A geologic section at Station $135+00$ is shown in Figure 4-1. The bedrock at the site is interbedded sandstone, shale and conglomerate. The bedding strikes $\mathrm{N}$. $200 \mathrm{~W}$. t the strike direction making an angle of 42 degrees with the cross section shown in Figure 4-1. The true dip of the beds is about 45 degrees easterly, and the apparent dip in cross section considered here varies from 45 to 60 degrees. The Gonzaga Fault System dissects the bedrock near the toe of the slope, the fault system trending N. 500 W. and dipping 80-90 degrees.

The clayey slopewash blankets the bedrock in the lower part of the hill on which the embankment was constructed at Station $135+00$, covering an area that extends from the toe of the dam about halfway to the centerline. Its thickness varies from zero at the upstream and downstream ends to a maximum of about 15 feet in the center of the area it covers.

In the section at Station $135+00$, the original 


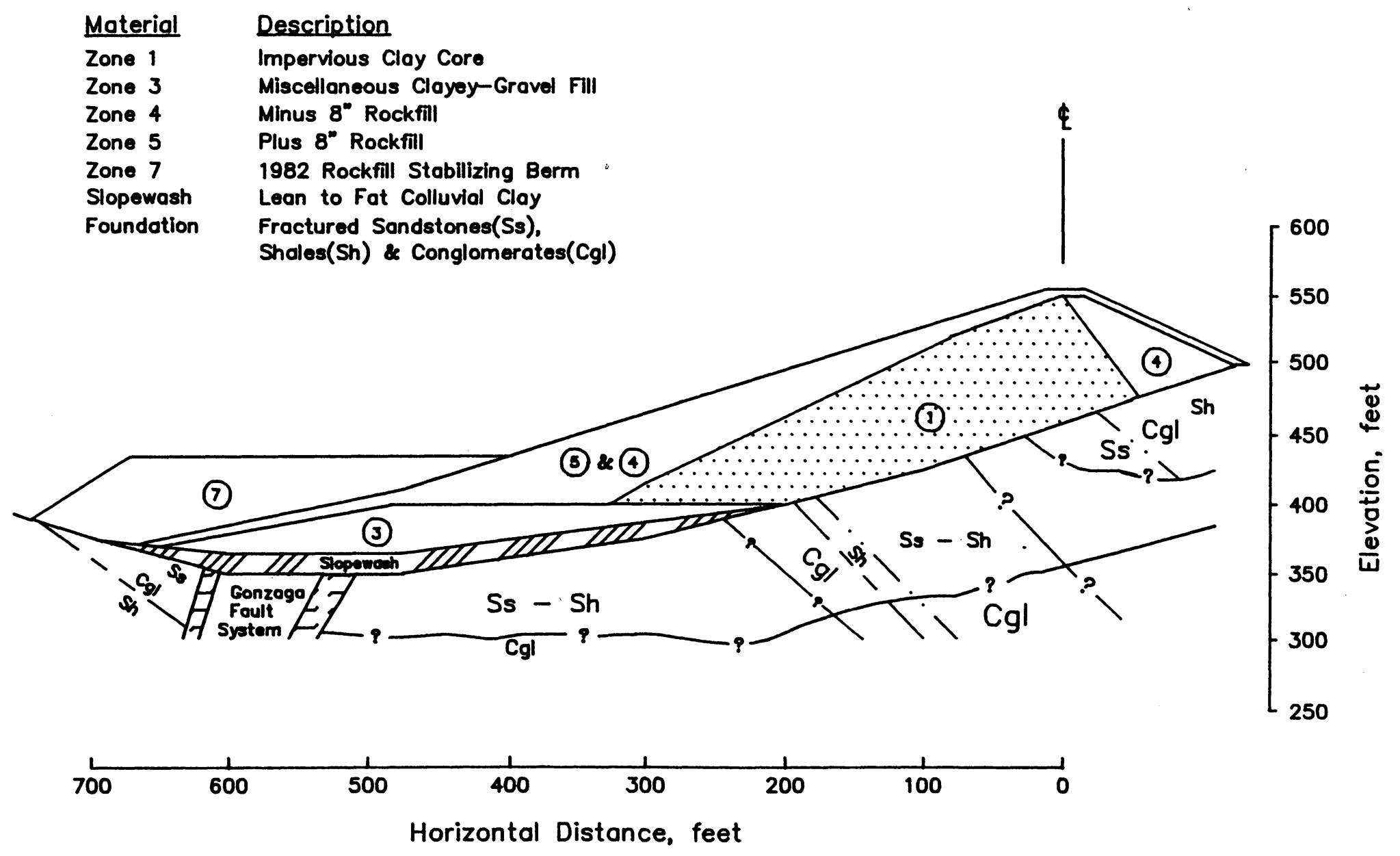

Figure 4-1 Cross Section at Station $135+00$ 
embankment contained four zones: the clay core, a miscellaneous clayey gravel fill over the top of the slopewash, and two zones of rockfill. After the 1981 slide, a stabilizing rockfill berm was constructed at the toe of the slope.

From a hydraulic point of view it is important to note that the upper portion of the foundation rock was more permeable than the slopewash, the'miscellaneous clayey gravel fill, or the clay core of the dam. Thus when the reservoir rises or falls, the changes in head are transmitted more rapidly through the foundation than the embankment. This fact, deduced from analysis of the responses of piezometers installed in the dam and the foundation, was important in establishing the seepage boundary conditions discussed in a subsequent section of this chapter.

\section{Piezometer Locations}

A total of thirteen piezometers were installed in five holes at Station $135+00$, as shown in Figure 4-2. Five of the piezometers were in the bedrock, three were in the slopewash, and five were within the embankment. Twelve of these appeared to perform well and provide reliable data.

As indicated previously, pore pressures measured using these piezometers were used to establish the seepage 


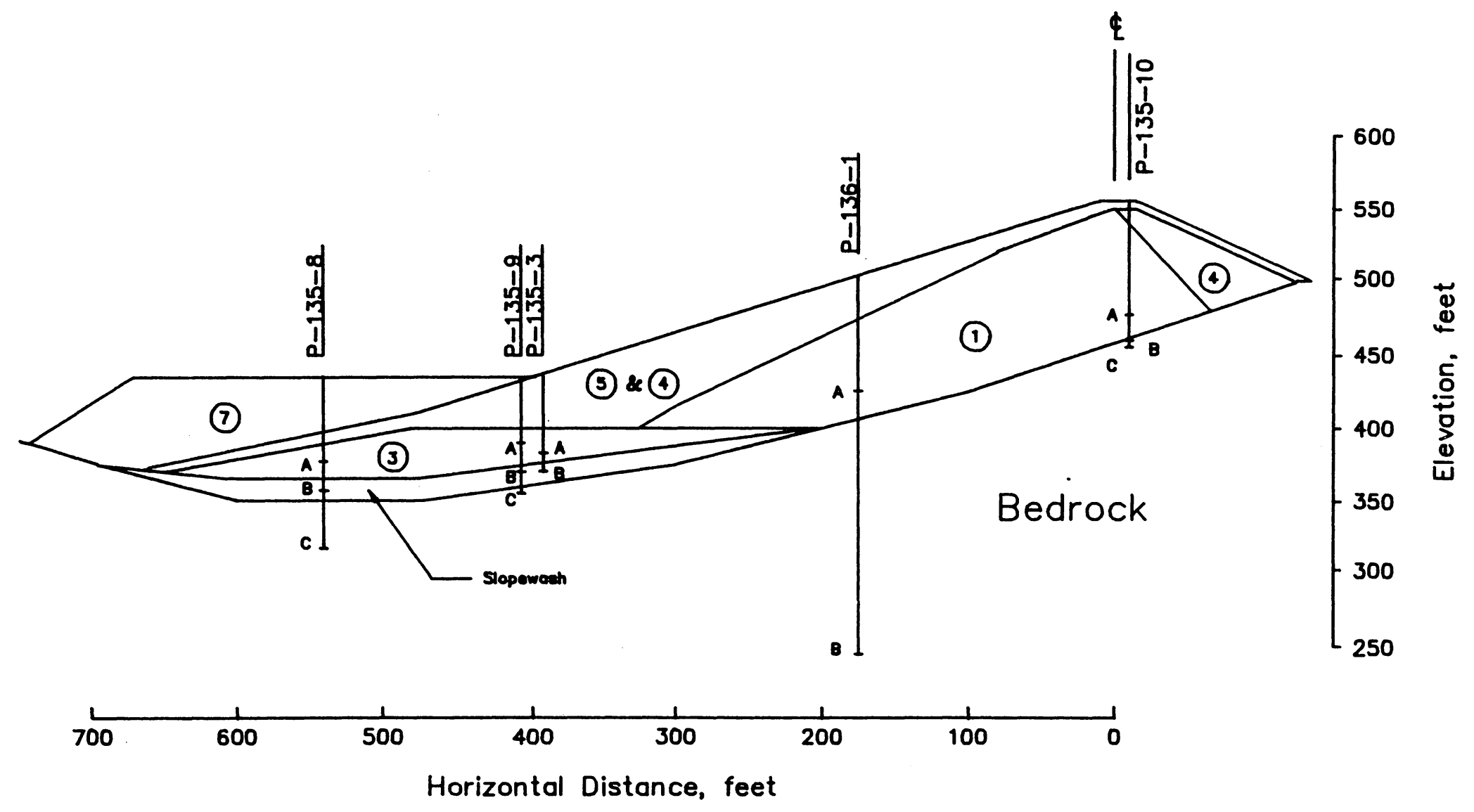

Figure 4-2 Location of Vibrating Wire Piezometers at Station $135+00$ 
boundary conditions for analysis, and to adjust the values of the parameters used in the analysis, to achieve the best possible agreement between analysis and observed field behavior.

\section{Reservoir History}

During the 13 years preceding the 1981 slide, the level of the San Luis Reservoir rose and fell a number of times, as shown in Figure 4-3. During the first five years, from 1969 to 1974, the reservoir level was kept at or near capacity. After 1974 the reservoir fell and rose each year, the lowest level being reached during the drought of 1977. The drawdown that preceded the 1981 slide was the largest, and among the fastest that the reservoir and the dam experienced.

The actual reservoir levels are shown by the solid line in Figure 4-3. The dotted line shows the simplified approximation of the actual reservoir levels that was used in the analyses described in this chapter.

\section{Soil Properties for Analysis}

The properties required for analysis of non-steady seepage through soil are listed in Table 4-1. These include ( 1 ) the variation of pressure head $(\psi)$ with volumetric water content (product of degree of saturation 
SAN LUIS DAM

RESERVOIR HISTORY

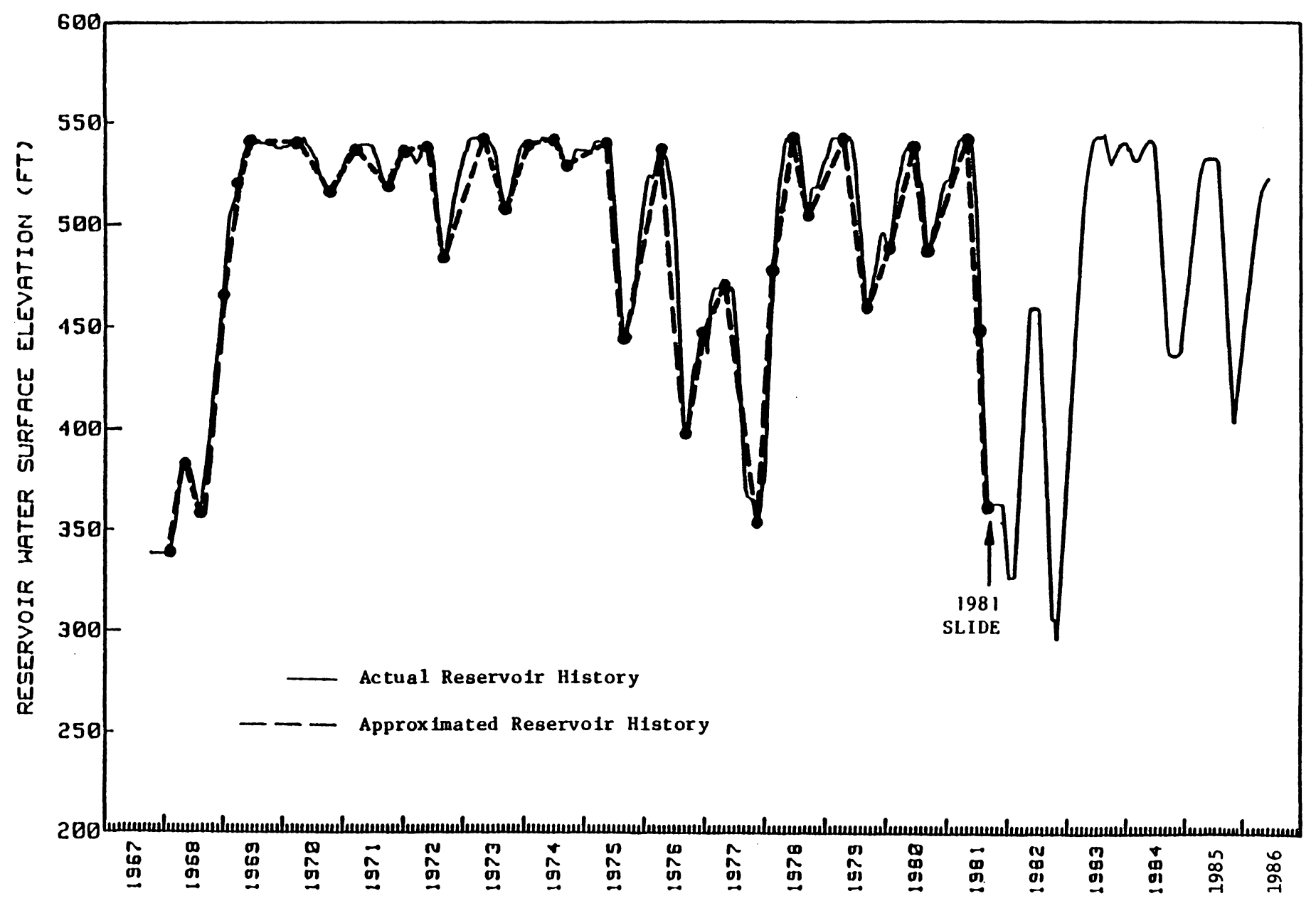

Figure 4-3 Actual and Approximated Reservoir History (Bureau of Reclamation, 1981) 
TABLE 4-1 - Soil Properties Required by UNSATl

Parameter

Soil Property

$\psi$

$\mathrm{Kr}_{r}$

Ks

$\eta$

Ss

$\psi_{0}$

\author{
Pressure Head \\ Relative Permeability \\ Saturated Permeability \\ Porosity
}

Specific Storage

Initial Pressure Head
Input Required by by UNSATI

$\psi=f(\theta)$
$k_{r}=f(\theta)$
$K_{s}$
$\eta$
Ss
$\psi_{0}$


and porosity, $\theta$ ); (2) the variation of relative permeability (ratio of unsaturated to saturated permeability, $\mathrm{Kr}$ ); (3) the porosity ( $\mathrm{n})$; (4) the specific storage (rate of change in water volume with change in head, Ss); and (5) initial suction or pressure head $\left(\psi_{0}\right)$. Variations of pressure head with volumetric moisture content for four different soils are shown in Figure 4-4. These curves, obtained from measurements by Mitchell, et al., (1965) and Olsen and Langfelder (1965), were used to estimate the variations needed for analysis, which are shown in Figure 4-5. Based on their Unified System classifications, it was estimated that the weathered rock materials in the foundation, the slopewash, zone 1 and $z$ one 3 had variations of pressure head with $\theta$ as shown in Figure 4-5. Subsequent analyses, performed using these and other variations, indicated that the calculated results were insensitive to the assumed variations. Virtually identical results were obtained regardless of what variation was assumed, the values of all other parameters being the same. The variation of relative permeability with volumetric moisture content used in the analyses is shown in Figure 46. This variation, estimated using data from Mitchell, et al., (1965), was used for the slopewash material, which had a porosity (maximum possible volumetric water content) equal to 0.29 . Similar curves, scaled to match their 


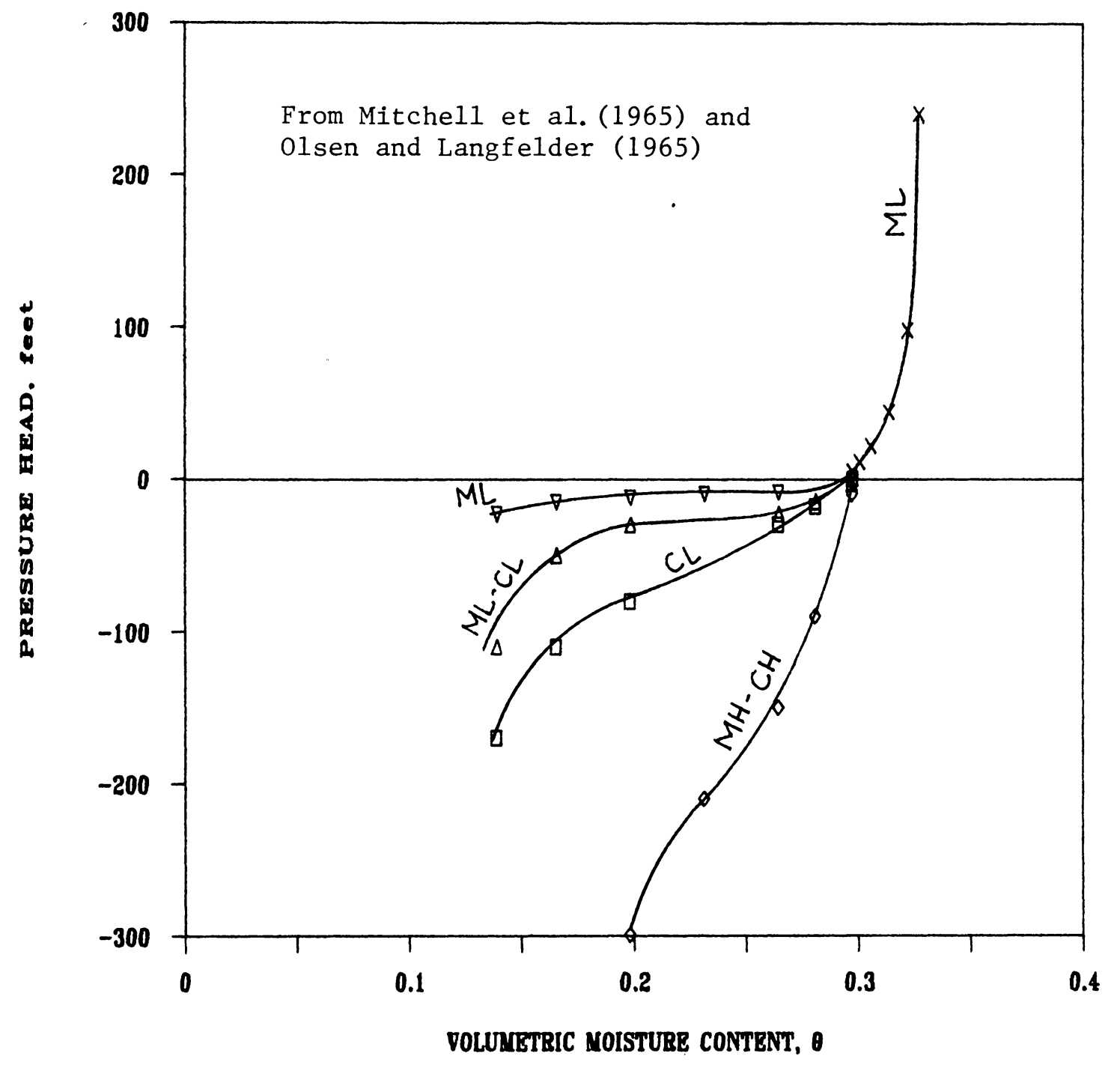

Figure 4-4 Variations of Pressure Head with Volumetric Moisture Content 


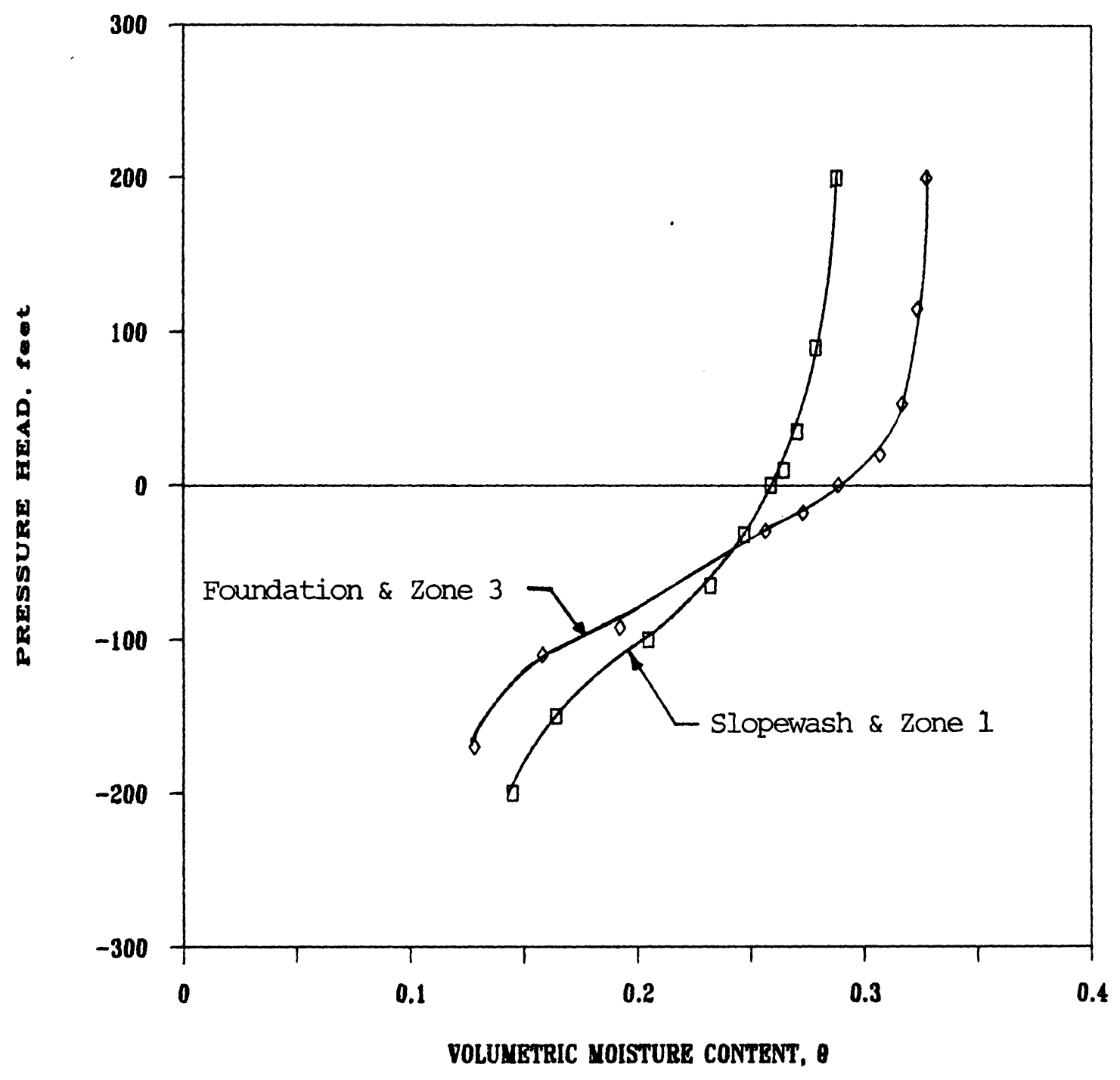

Figure 4-5 Variations of Pressure Head with Volumetric Moisture Content used in Seepage Analyses 


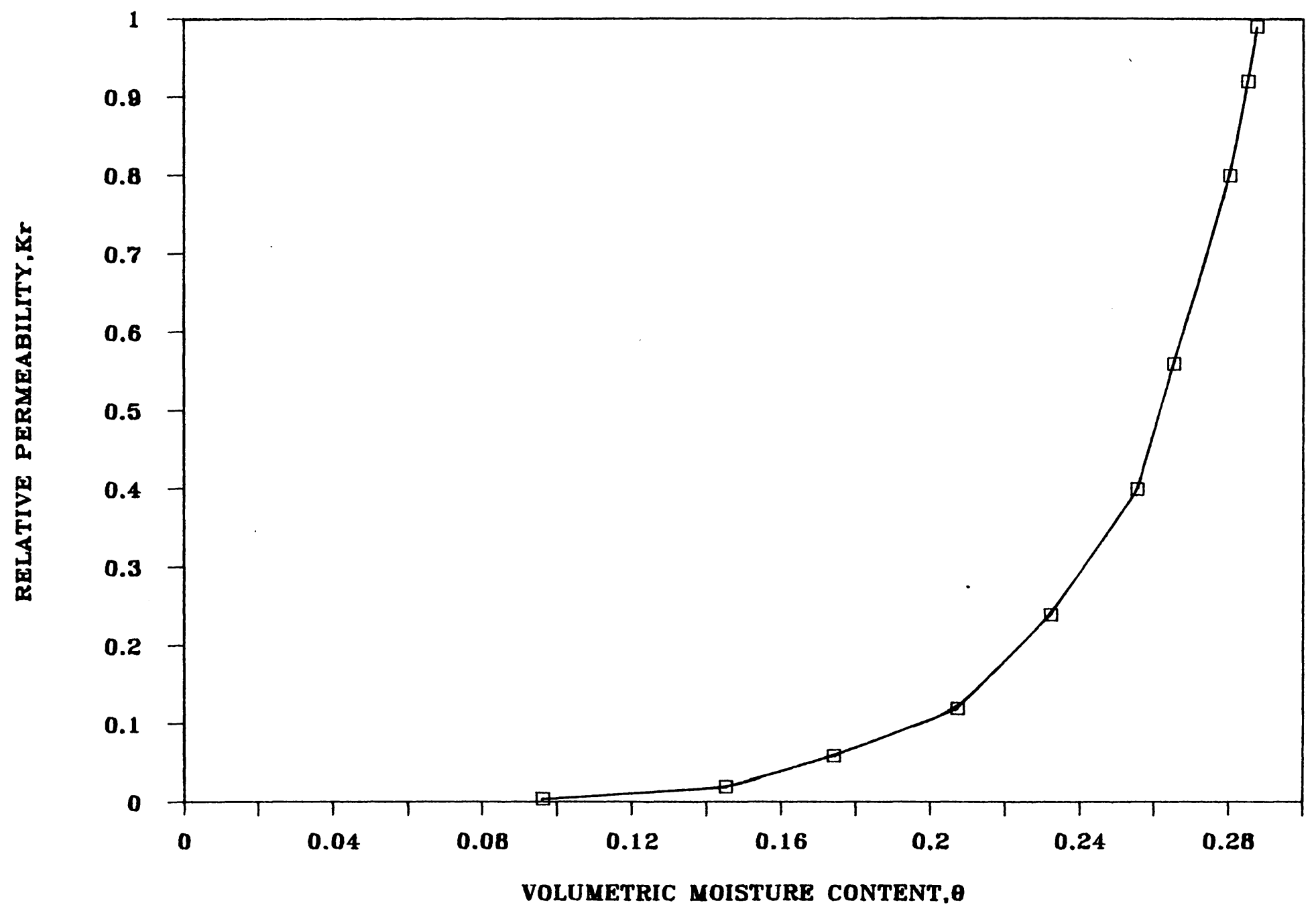

Figure 4-6 Variation of Relative Permeability with Volumetric Moisture Content after Mitchell et al. (1965) 
porosities, were used for the weathered rock foundation and embankment materials.

The initial pressure heads before first reservoir filling are shown in Table 4-2, together with the characteristics of the various zones that were used as the basis for estimating these values. The calculated heads changed quickly once the reservoir was filled and the assumed initial heads had no significant affect on the calculated time lag in the slopewash pore pressures, or on the estimated rate of movement of the phreatic surface through the embankment.

The ranges of permeabilities, specific storage, and porosity values for the slopewash are shown in Table 4-3. Also shown in Table 4-3 is the "calibrated value" of each of these quantities, found to result in the best achievable agreement between the calculated pore pressures and those measured after the 1981 slide. It can be seen that all of the calibrated values fall in the range of the measured values, indicating that the results are reasonable.

Table 4-4 gives a summary of the values of the material properties for the embankment and foundation materials used in the seepage analyses. The values of permeability shown for the Zone 1, Zone 3 and the rock foundation were provided by the Bureau of Reclamation (1983). The other properties for these materials were 
TABLE 4-2 - Index Properties and Initial suction Head Values

\section{MATERIAL TYPE}

\section{Soil \\ Property}

Plastic Limit

Liquid Limit

Plasticity Index

Water Content,W.C.
17

40-47

23-30

15

Optimum W.C.

Ave. Place. W.C. -1.3

Initial Degree of

Saturation, \& 90

Pore Pressure

Ratio, $r_{u}$

Porosity

0.29

0.1

0.1

0.33

Volumetric Moisture Content

14
$28-35$
$14-21$
14

16

$-1.4$

$80-85$
**

Slopewash
Rock

Foundation

Initial suction

Head, ft.

$-25$

$-20$

$-40$

0.0

* data from Bureau of Reclamation, (1983)

** data from laboratory testing at Virginia Tech, (1986)

$\star \star *$ permeabilities from Bureau of Reclamtion, others estimated 

TABLE 4-3 - Measured and Calibrated Values of Saturated Permeability, Specific storage and Porosity in the slopewash

Slopewash Property

Vertical

Saturated

Permeability.

feet/year

(15 values)

Horizontal

Saturated

Permeability.

feet/year

(Estimated)
Measured Range

Minimum

Average

Maximum

Calibrated

Value

0.001

0.0039

0.068

0.011

0.0156

0.272

0.044

0.004

0.272

0.044

Specific

storage,

$1 /$ feet

$0.000068 \quad 0.0003$

0.002

0.000068

(15 values)

Porosity

0.28

0.35

0.45

0.35 
TABLE 4-4 - Summary of Material Properties Used in Analyses of the Response of the Slopewash

\section{MATERIAL TYPE}

\section{Soil Property}

Vertical

Saturated

Permeability,

feet/year

Horizontal

Saturated

Permeability,

feet/year

Porosity

Specific

Storage,

1 /feet

Relative

Permeability

Relationship

Pressure Head

Relationship

Initial

Suction Head, feet
Zone 1 Zone 3

Slopewash Foundation

Rock

$0.07 * \quad 0.37 * \quad \begin{aligned} & \text { Initial: } 0.02 \\ & \text { Final: } 0.011 \quad 1.0 *\end{aligned}$

I: 0.08

$\mathrm{F}: 0.044$

$4.0 *$

0.28 * 1.48 *

$0.33 *$

0.29

$0.05 *$

$0.29 *$

$0.33 *$

0.0000250 .00001

I: 0.00001

F : 0.000068

0.00005

$\begin{array}{llll}\text { Figure } 6 & \text { Figure } 6 & \text { Figure } 6 & \text { Figure } 6\end{array}$

Figure 5 Figure 5 Figure $5 \quad$ Figure 5

* data from Bureau of Reclamation, (1983)

Final (F) values are the calibrated values 
estimated and then calibrated using measured pore pressures. The initial and final values of permeability and specific storage used in the calibration of the slopewash properties are also included.

\section{Analysis Procedure}

The 1981 slide is believed to have originated in the vicinity of Station $135+00$ and thus the seepage analyses concentrated on this cross section. Figure 4-7 shows the UNSATI finite element mesh used for analysis of the full cross section at station $135+00$. The analyses were conducted on an IBM-PC XT and other smaller meshes were also used to reduce computation time, as explained in the following paragraphs.

Figure 4-8 shows a partial mesh that was used for analysis of time lag in the slopewash material. This mesh is the same as the full mesh except that it extends only about 550 feet downstream from the upstream toe of the dam. Pore pressures were calculated using the same soil properties in the meshes shown in Figures $4-7$ and 4-8, with the reservoir at an elevation of 540 feet. The calculated values of elevation head at nodes 35 and 65 are plotted in Figure 4-9. Both of these nodes are located at the top of the slopewash material. From Figure 4-9 it can be seen that the meshes gave identical results, the symbols for 


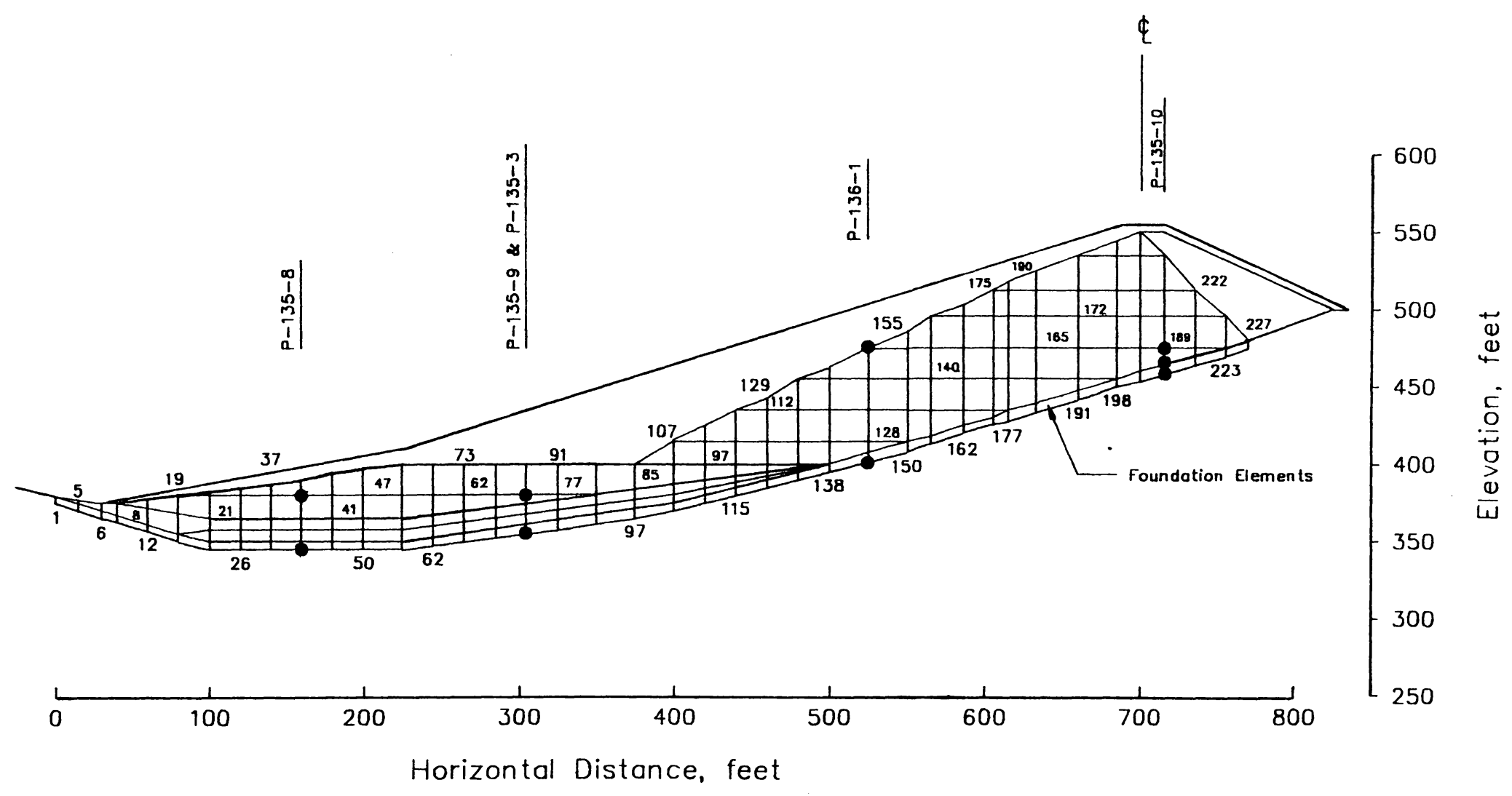

Figure 4-7 Full Seepage Analysis Mesh at Station $135+00$ 


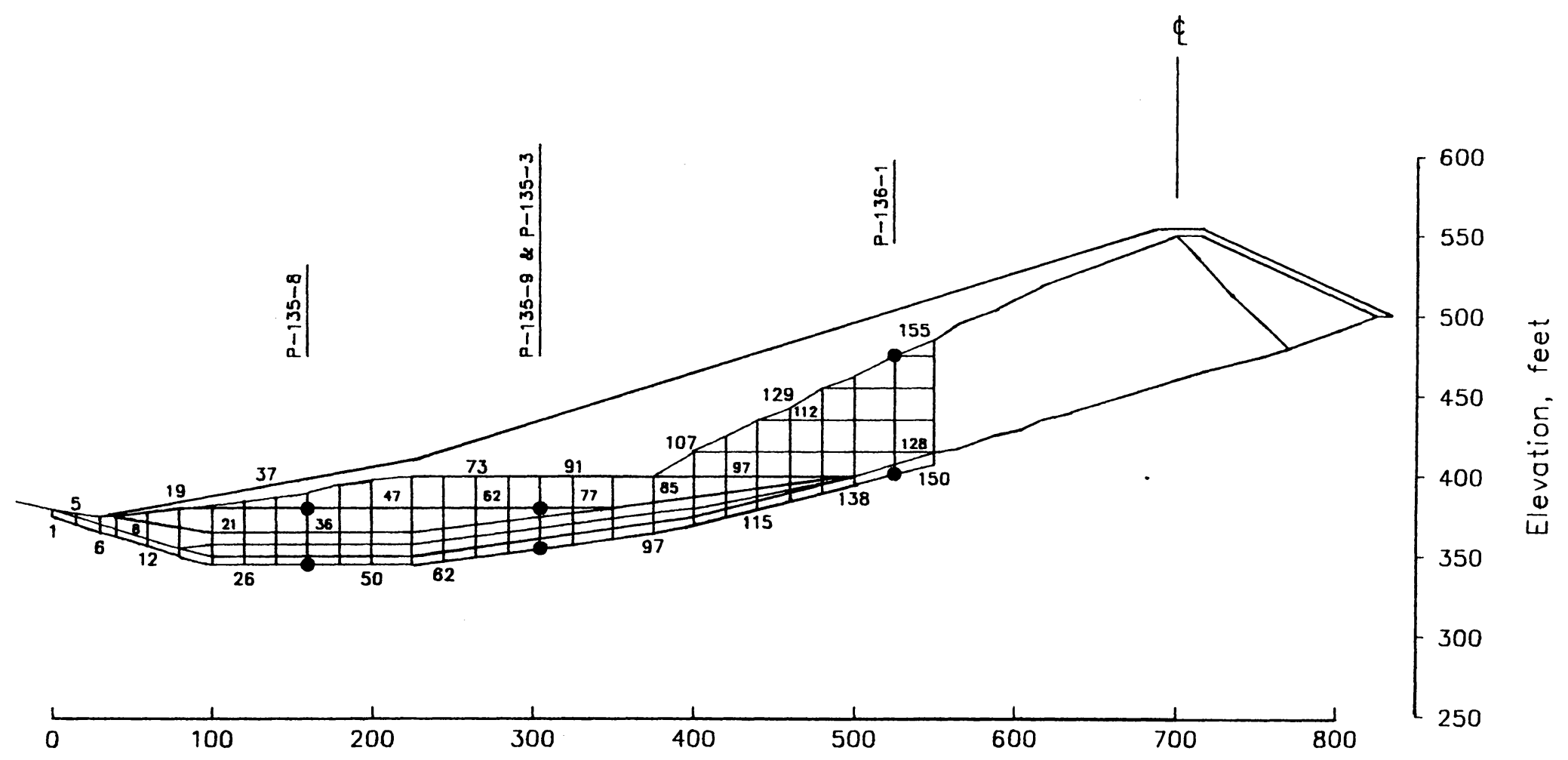

Horizontal Distance, feet

Figure 4-8 Slopewash Seepage Analysis Mesh at Station 135+00 


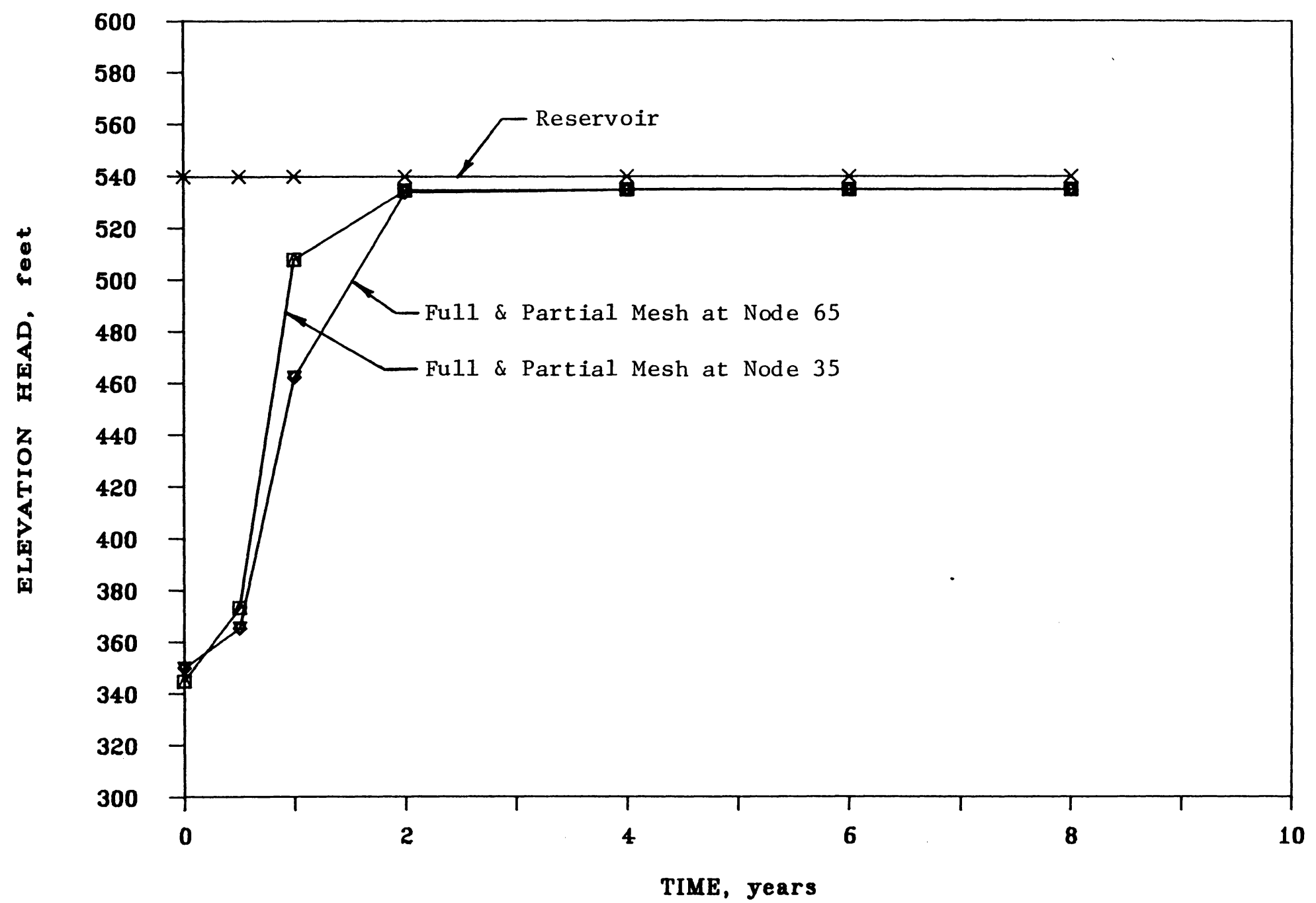


both nodes overlying each other. It was therefore concluded that the slopewash could be modeled using the partial mesh shown in Figure 4-8.

A similar analysis was conducted to determine whether the Zone 1 material could be approximated using the partial mesh shown in Figure 4-10 instead of the full mesh shown in Figure 4-7. Values of elevation head calculated using the two meshes with the reservoir at elevation 540 feet are shown in Figure 4-11. It can be seen that the results are identical. Therefore, seepage in Zone 1 was modeled using the mesh shown in Figure 4-10.

This process of mesh simplification was carried further by investigating the possibility of analyzing seepage through the slopewash using a one dimensional column mesh. Figure 4-12 shows the full mesh for station $135+00$ and a one dimensional column mesh located about 225 feet downstream from the upstream toe. The results of two analyses performed using these meshes are shown in Figure 4-13, where it can be seen that the one dimensional column mesh gave the same results as comparable nodes in the full mesh. Going one step further, a similar one dimensional column mesh with a width of one foot was found to give the same results as the 25 foot wide column mesh and was subsequently used for analyses of head changes at 


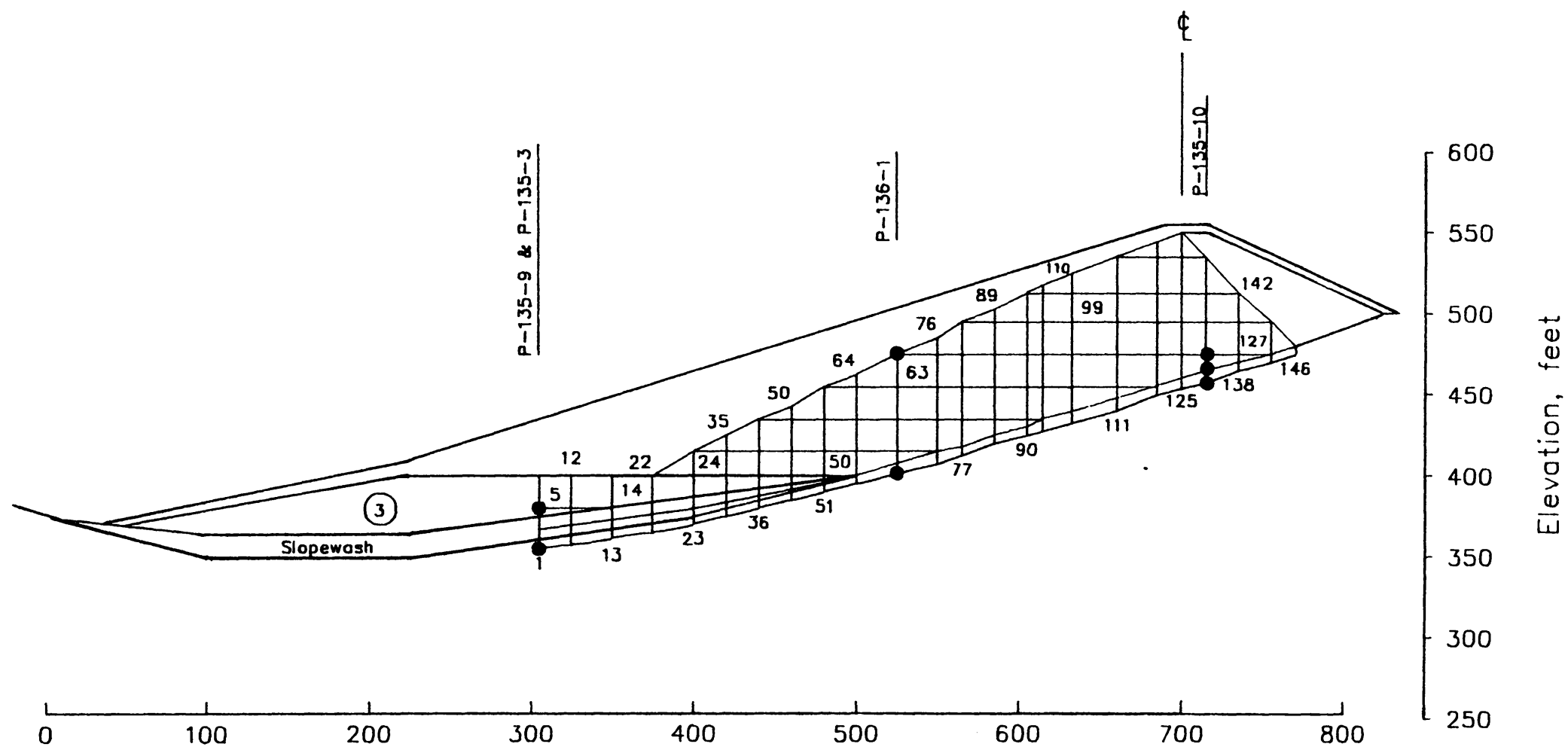

Horizontal Distance, feet

Figure 4-10 Zone 1 Seepage Analysis Mesh at Station 135+00 


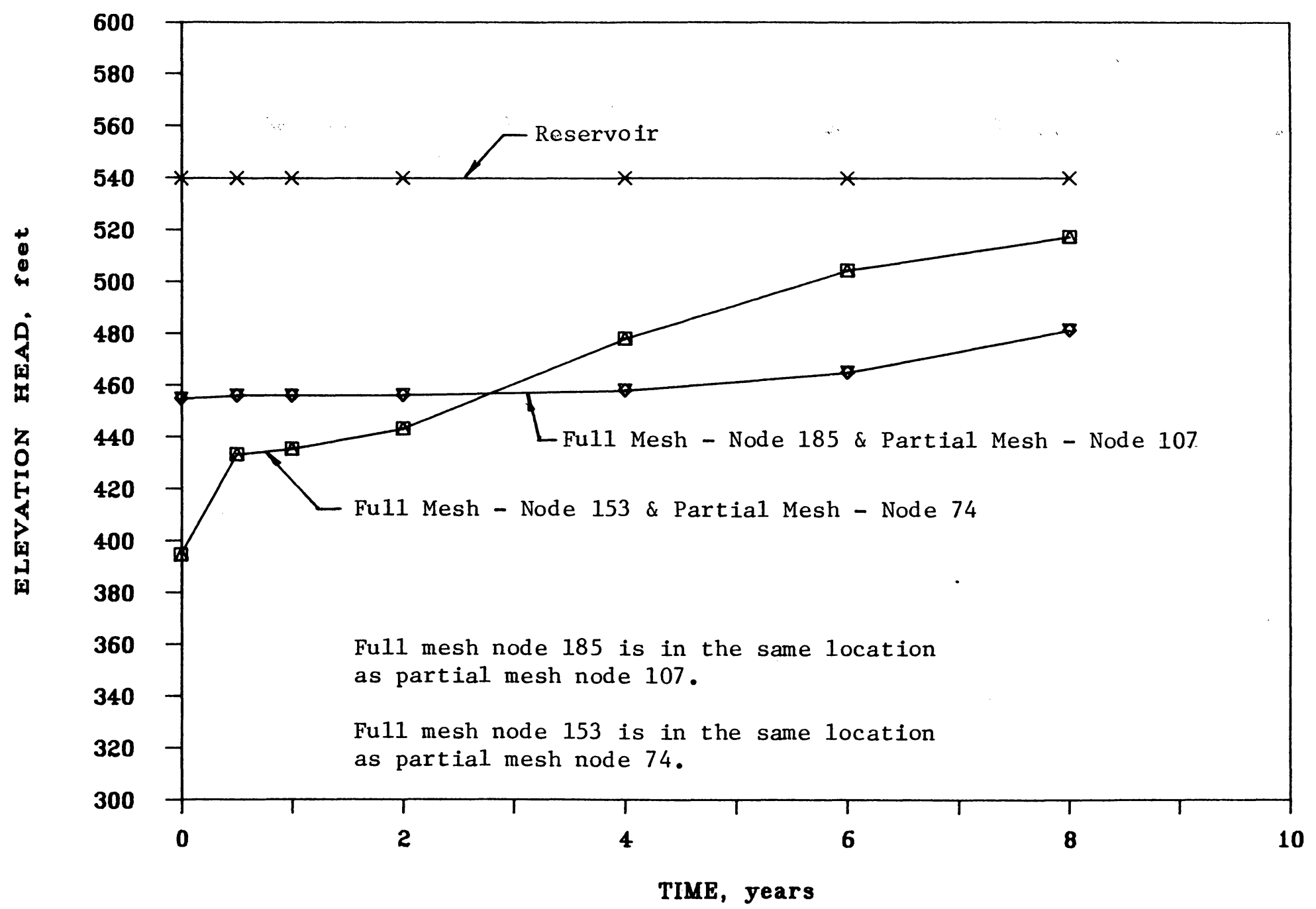

Figure 4-11 Comparison of Results Calculated Using Fu11 and Zone 1 Meshes 


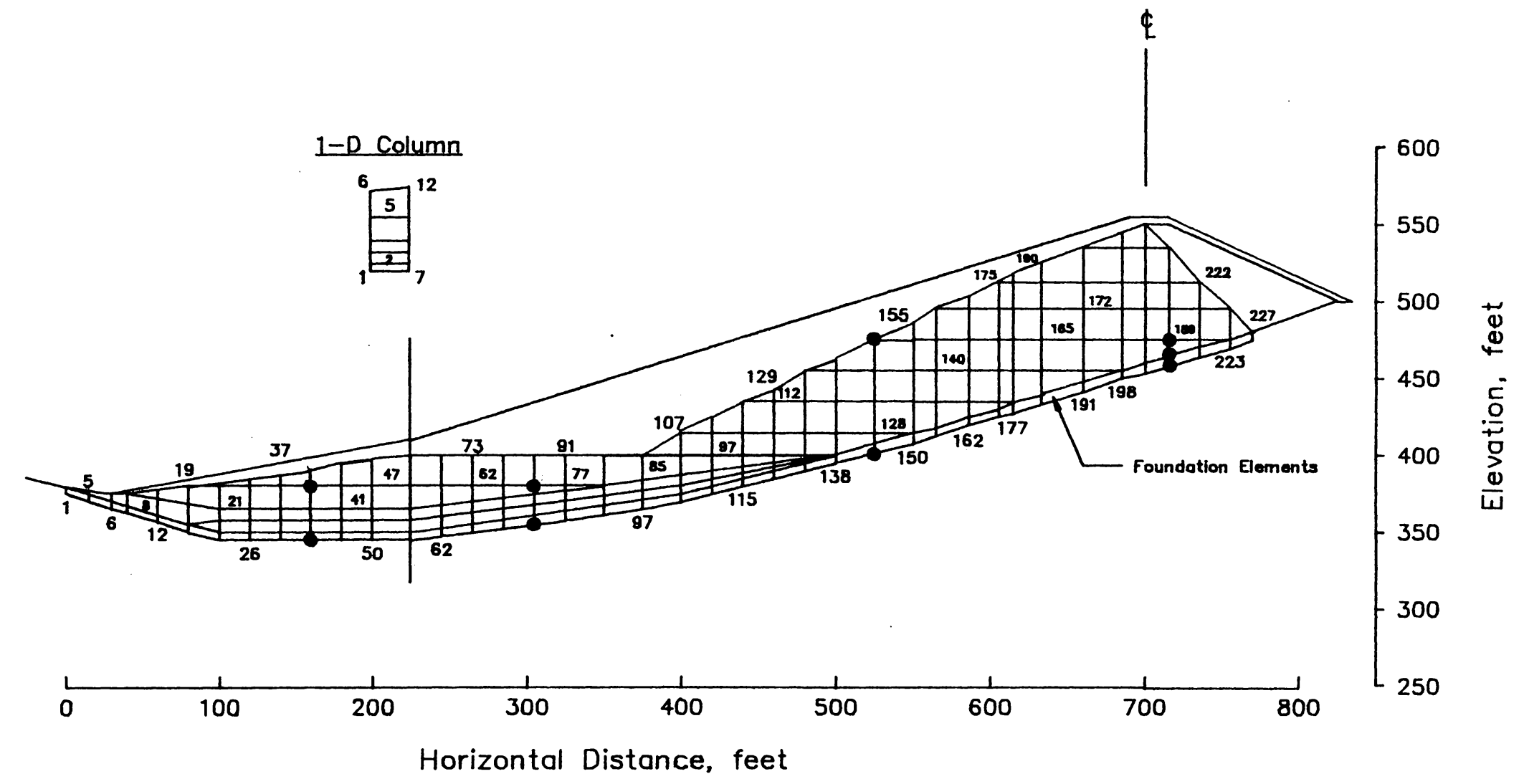

Figure 4-12 Full Seepage Analysis Mesh and One Dimensional Column at Station $135+00$ 


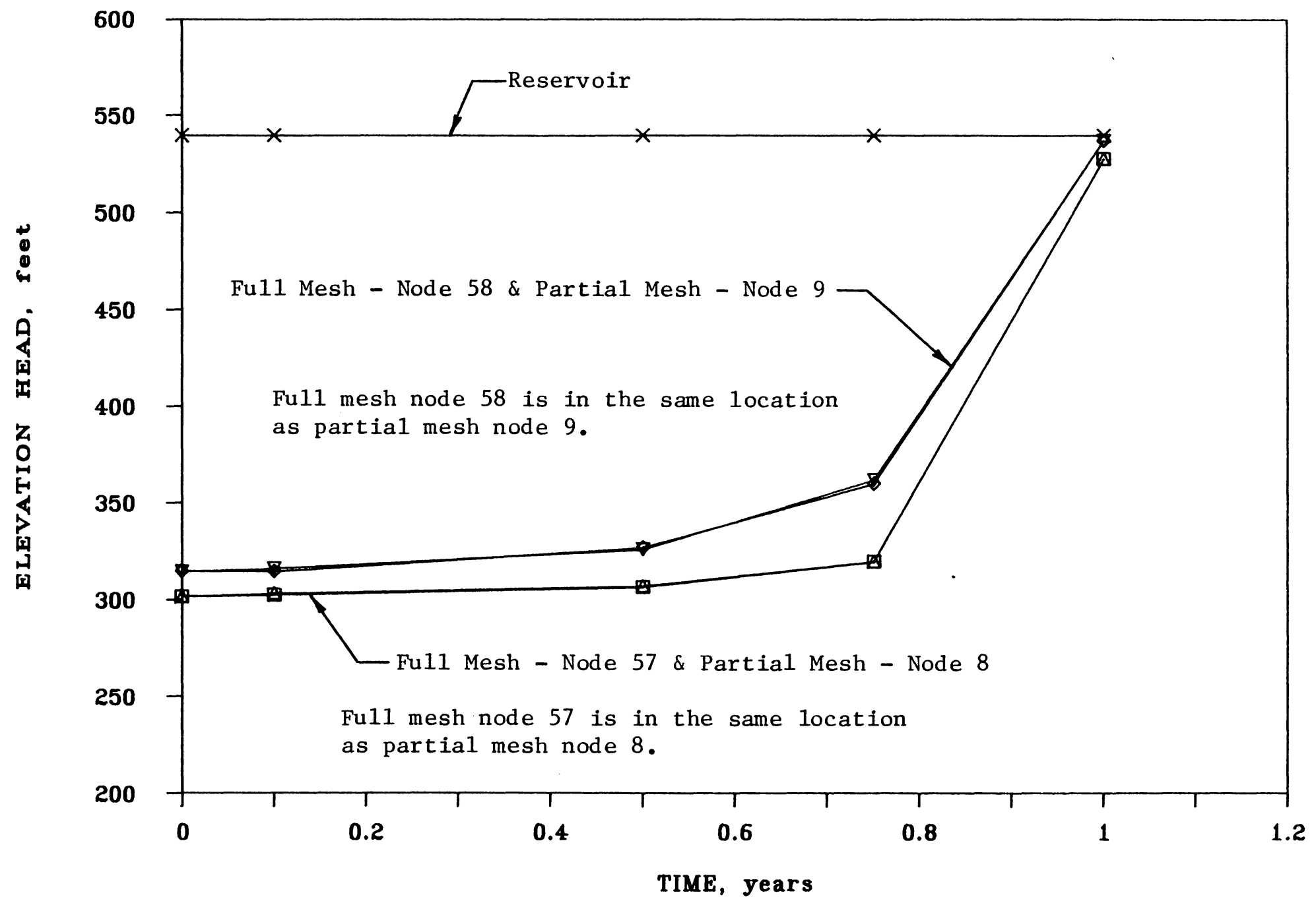

Figure 4-13 Comparison of Results Calculated Using Full Mesh and a One Dimensional Column Mesh 
piezometer locations.

\section{Boundary Conditions}

Piezometer data from January, 1983 to March, 1986, provided by the California Department of Water Resources, was used to establish the seepage boundary conditions. During that time period the reservoir underwent three distinct movements: a 102 foot drawdown in 1984, a 93 foot refilling in 1984-85, and a 125 foot drawdown in 1985. These drawdowns are similar to, although not as large as, the 1981 drawdown. These measured pore pressures provide a good basis for establishing the seepage boundary conditions and refining the material properties for the seepage analyses.

Figure 4-14 shows the pore pressure responses measured in the foundation piezometers, 135-9C, 135-8C and 136-1B, from February, 1984 to February, 1986. From Figure 4-14 it may be seen that the foundation pore pressures varied directly with the reservoir, but at pressures lower than hydrostatic. Piezometers $8 \mathrm{C}$ and $9 \mathrm{C}$ show piezometric levels that are consistently about $20 \mathrm{ft}$. below the reservoir level, while piezometer $1 B$ shows heads roughly $70 \mathrm{ft}$. below reservoir level. Piezometers $8 \mathrm{C}$ and $9 \mathrm{C}$ are located at elevation 345 and 355 feet, respectively, while $1 \mathrm{~B}$ is located approximately 110 feet below the other two, at 


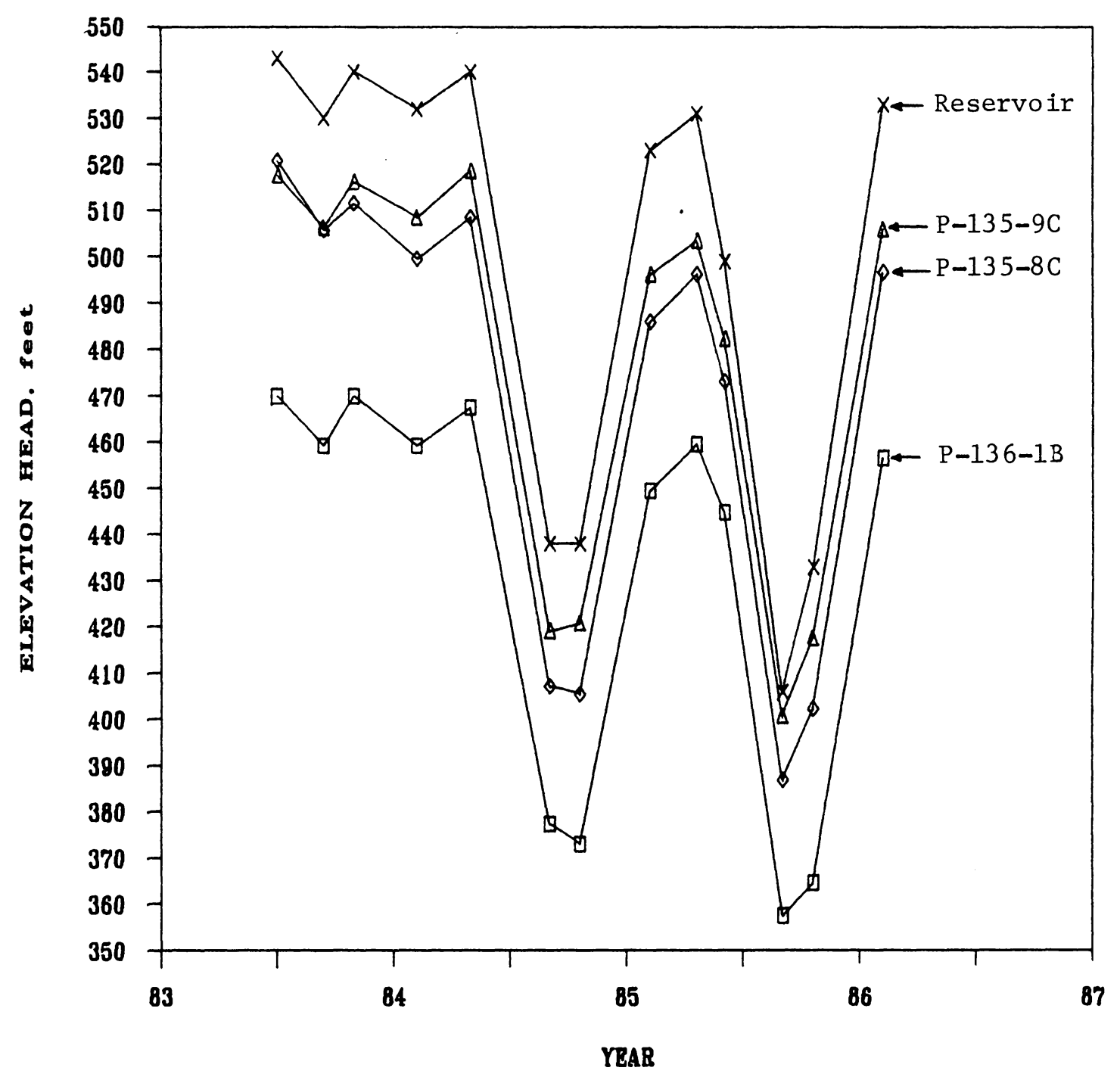

Figure 4-14 Foundation Piezometer Measurements 
elevation 243 feet. The observed decrease in pore pressure with depth indicates flow into the foundation. Since modeling the pore pressure response in the slopewash was the main objective of the analyses, it was decided to represent the foundation seepage as a boundary condition, using pressure heads 20 feet below the reservoir head at the location of piezometers $8 \mathrm{C}$ and $9 \mathrm{C}$, and a head 70 feet below reservoir at the location of piezometer $1 \mathrm{~B}$.

The heads measured at the other piezometers were also compared to the reservoir levels, as shown in Figure 4-15. It was found that the heads at piezometers 135-3A, 135-8A, and $135-9 A$ (in Zone 3 ) maintained constant differences from the reservoir level, and so the heads at the locations of these piezometers were specified as boundary conditions in the seepage analyses, as shown in Table 4-5.

The head measured at piezometer 136-1A (in Zone 1) did not maintain a constant difference from the reservoir level. It evidenced a time lag, and a consequent variable difference from reservoir level. Therefore the head at this location was not specified as a boundary condition. Instead, the lag in response was used to determine the best value of specific storage for the Zone 1 material.

No response was measured at piezometer 135-10A, and a head boundary condition of $0 \mathrm{ft}$. above the piezometer tip elevation was used at this location. At piezometer 135-10B 


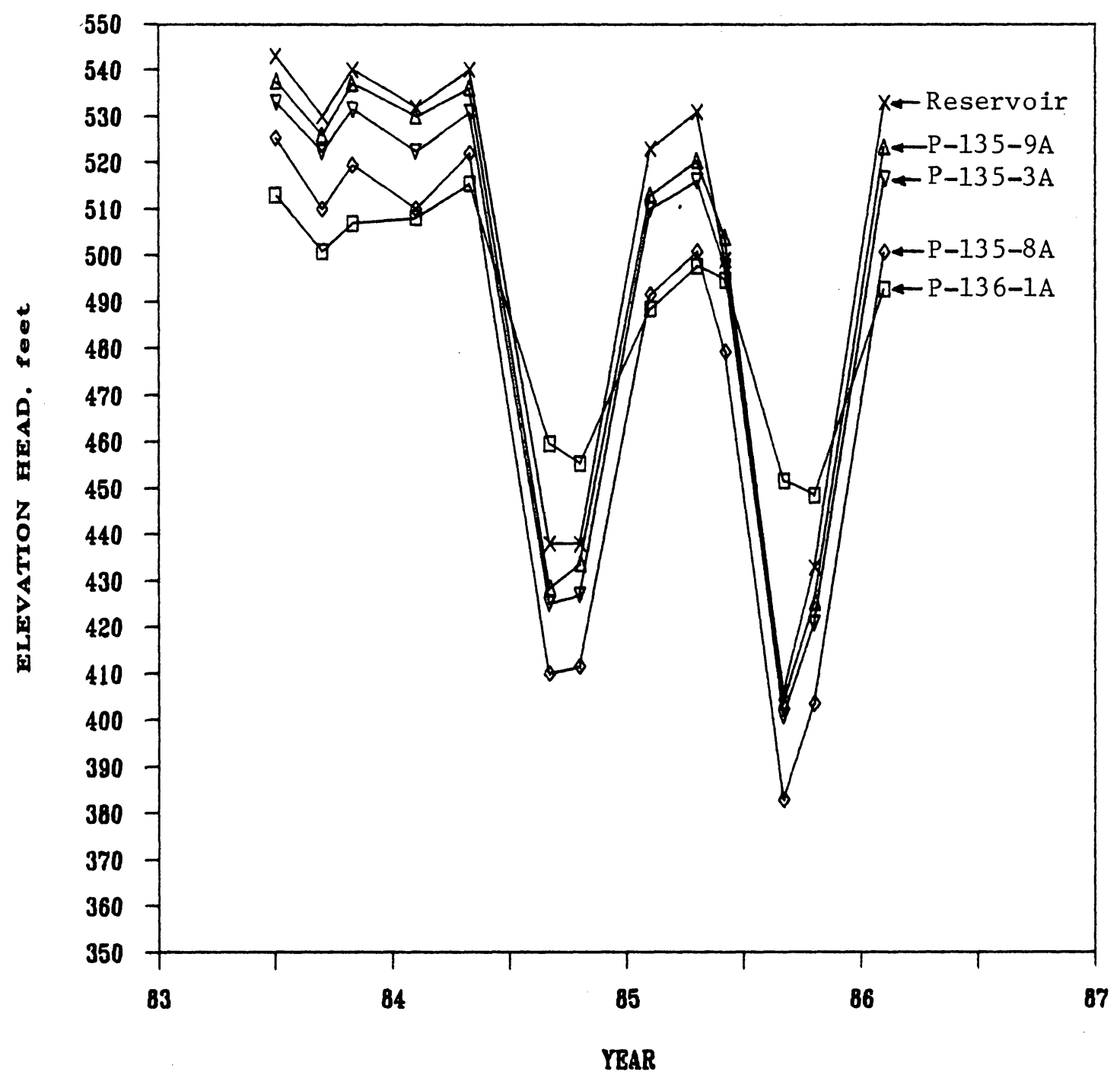

Figure 4-15 Zone 1 and 3 Piezometer Measurements 
TABLE 4-5 - Piezometer Locations and Boundary Conditions

\begin{tabular}{|c|c|c|c|c|}
\hline Piezometer & Location & $\begin{array}{c}\text { Tip } \\
\text { Elevation }\end{array}$ & Material & $\begin{array}{l}\text { Boundary * } \\
\text { Condition }\end{array}$ \\
\hline $\begin{array}{r}P-135-9 A \\
-9 B \\
-9 C\end{array}$ & & $\begin{array}{l}380^{\prime} \\
373^{\prime} \\
355^{\prime}\end{array}$ & $\begin{array}{l}\text { Zone } 3 \\
\text { Slopewash } \\
\text { Foundation }\end{array}$ & $\frac{8^{\prime}}{20^{\prime}}$ \\
\hline $\begin{array}{c}P-135-3 A \\
-3 B \\
9 C \text { applied }\end{array}$ & $\begin{array}{c}391 ! \\
n\end{array}$ & $\begin{array}{l}383^{\prime} \\
375^{\prime} \\
360\end{array}$ & $\begin{array}{l}\text { Zone } 3 \\
\text { Slopewash } \\
\text { Foundation }\end{array}$ & $\frac{10^{\prime}}{20^{\prime}}$ \\
\hline $\begin{array}{r}P-135-8 A \\
-8 B \\
-8 C\end{array}$ & $\begin{array}{c}538 ! \\
n \\
n\end{array}$ & $\begin{array}{l}380^{\prime} \\
358^{\prime} \\
345^{\prime}\end{array}$ & $\begin{array}{l}\text { Zone } 3 \\
\text { Slopewash } \\
\text { Foundation }\end{array}$ & $\frac{25^{\prime}}{30^{\prime}}$ \\
\hline $\begin{array}{r}P-135-10 \mathrm{~A} \\
-10 \mathrm{~B} \\
-10 \mathrm{C}\end{array}$ & $\begin{array}{c}-8 ! \\
n \\
n\end{array}$ & $\begin{array}{l}475^{\prime} \\
464^{\prime} \\
458^{\prime}\end{array}$ & $\begin{array}{l}\text { Zone } 1 \\
\text { Foundation } \\
\text { Foundation }\end{array}$ & $\begin{array}{l}0^{\prime} \text { ** } \\
0^{\prime}-20^{\prime} \\
0^{\prime}-20^{\prime}\end{array}$ \\
\hline $\begin{array}{c}\mathrm{P}-136-1 \mathrm{~A} \\
-1 \mathrm{~B} \\
\text { Calibrated }\end{array}$ & $\begin{array}{c}176 ! \\
n \\
n\end{array}$ & $\begin{array}{l}475^{\prime} \\
243^{\prime} \\
400^{\prime}\end{array}$ & $\begin{array}{l}\text { Zone } 1 \\
\text { Foundat ion } \\
\text { Foundation }\end{array}$ & $\begin{array}{l}-\overline{65} \\
15\end{array}$ \\
\hline
\end{tabular}

* Values are in feet below reservoir level.

* No response was observed in piezometer $10 \mathrm{~A}$, so $0 \mathrm{ft}$. was applied at all times. At piezometers 10B \& 10C a response between 0 and $-20 \mathrm{ft}$. was observed. 
and $10 \mathrm{C}$, head boundary conditions from zero to $20 \mathrm{ft}$. below reservoir level were used.

\section{Adjustment of Soil Properties}

Figure 4-16 shows the slopewash pore pressures recorded by piezometers 135-3B, 135-8B and 135-9B from February, 1984 to February, 1986. Of special interest is the pore pressure lag observed in piezometer 135-9B during drawdown and refilling. A similar, even larger, lag was observed in the Zone 1 material (piezometer 136-1A in Figure 4-15) as mentioned previously. These measurements confirm that the pore pressures in the slopewash and the clay core lagged behind the falling reservoir during the 1981 drawdown and the pore pressures in these zones were thus higher than would be estimated assuming no lag. The measured responses in piezometers $3 \mathrm{~B}, 8 \mathrm{~B}$ and $9 \mathrm{~B}$ were used to calibrate the properties of the slopewash for use in the seepage analyses. The calibration process initially concentrated on the response of piezometer 135-9B because of its location at the middle of the slopewash and its noteworthy pore pressure lag. The calibration of piezometer $135-9 \mathrm{~B}$ involved a lengthy iterative process in which the six soil properties given in Table 4-1 were varied until the best possible agreement between the measured and calculated pore pressures was obtained. 


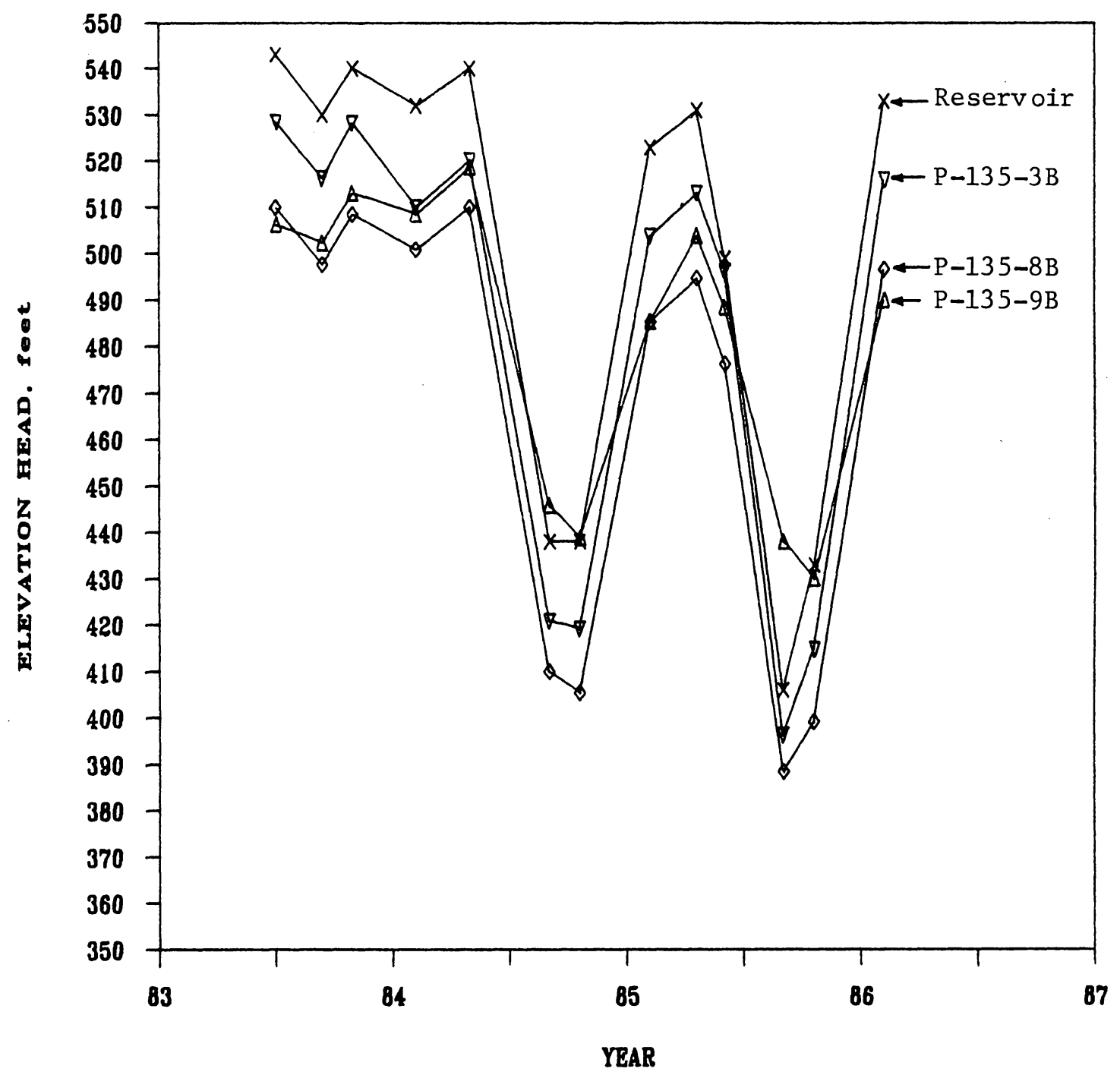

Figure 4-16 Slopewash Piezometer Measurements 
Figures $4-17,4-18$ and $4-19$ show the results of the first calculation of the response of piezometer 135-9B using the initial soil property values. Table 4-4 summarizes the soil properties used in the first analysis and Figure 4-20 shows the one foot wide column mesh used to represent piezometer 135-9. Figure 4-17 shows the calculated and measured pore pressures for the 1984 summer drawdown. The measured values are shown as solid points and the calculated values are shown as open points. The calculated pore pressures at the center of the slopewash underestimated the values measured in September, 1984 by about 20 feet. Similarly, the analysis performed using the initial soil properties overestimated the pore pressures during refilling of the reservoir, as shown in Figure 4-18, and underestimated the pore pressure lag by about 40 feet during the 1985 drawdown, as shown in Figure 4-19.

The next step in the calibration process was to change the values of the slopewash soil properties to achieve better agreement between the calculated and measured pore pressures. To facilitate the matching process a parametric study was conducted to determine the effect each of the six soil properties used in UNSATI had on the calculated pressure heads. The parametric study was conducted using the mesh for piezometer $135-9$ and the reservoir history from February, 1984 to March, 1986. The results of the 


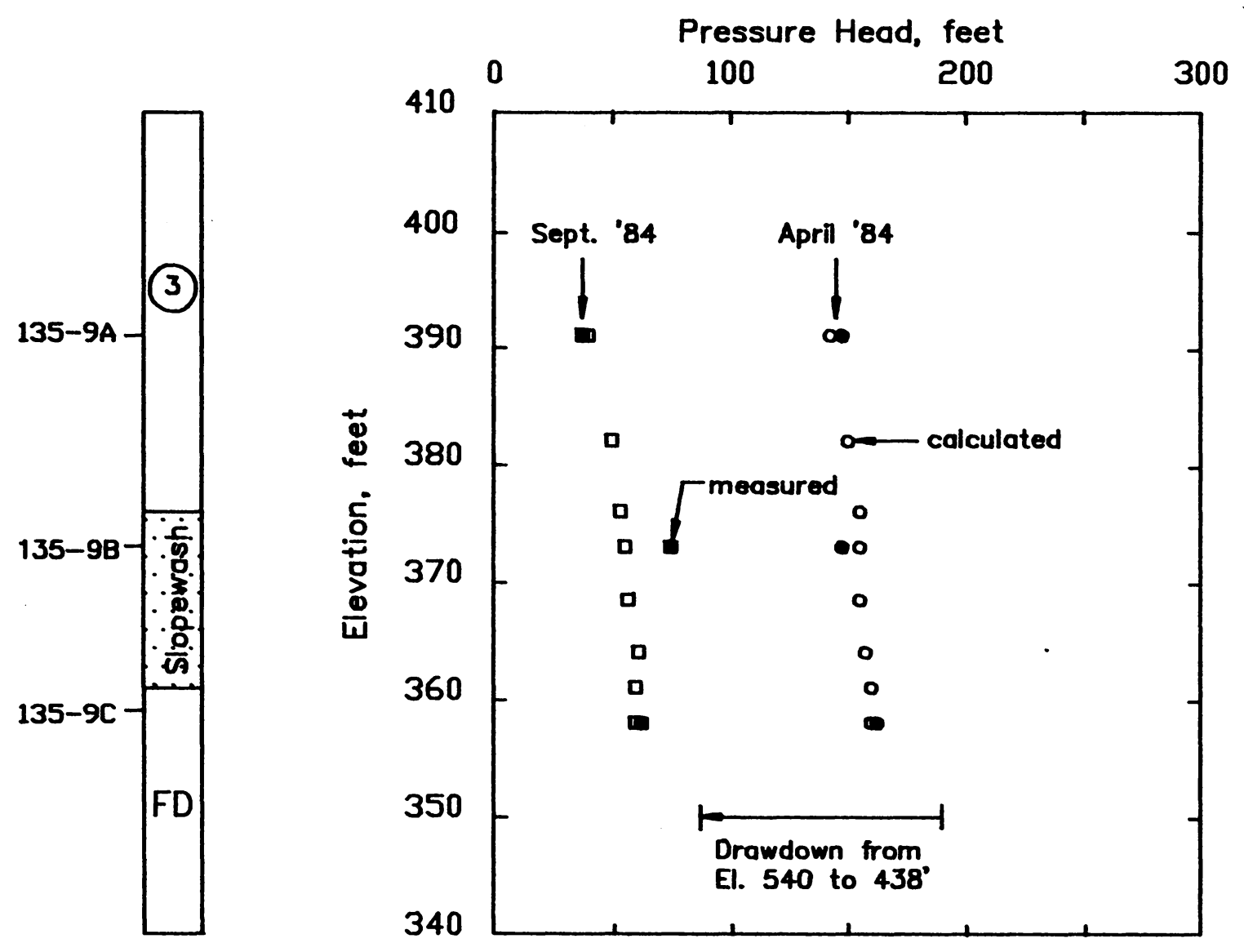

Figure 4-17 Comparison of Measured Heads at Piezometer 135-9 During 1984 Drawdown, with Values

Calculated Using Initial Soil Properties 


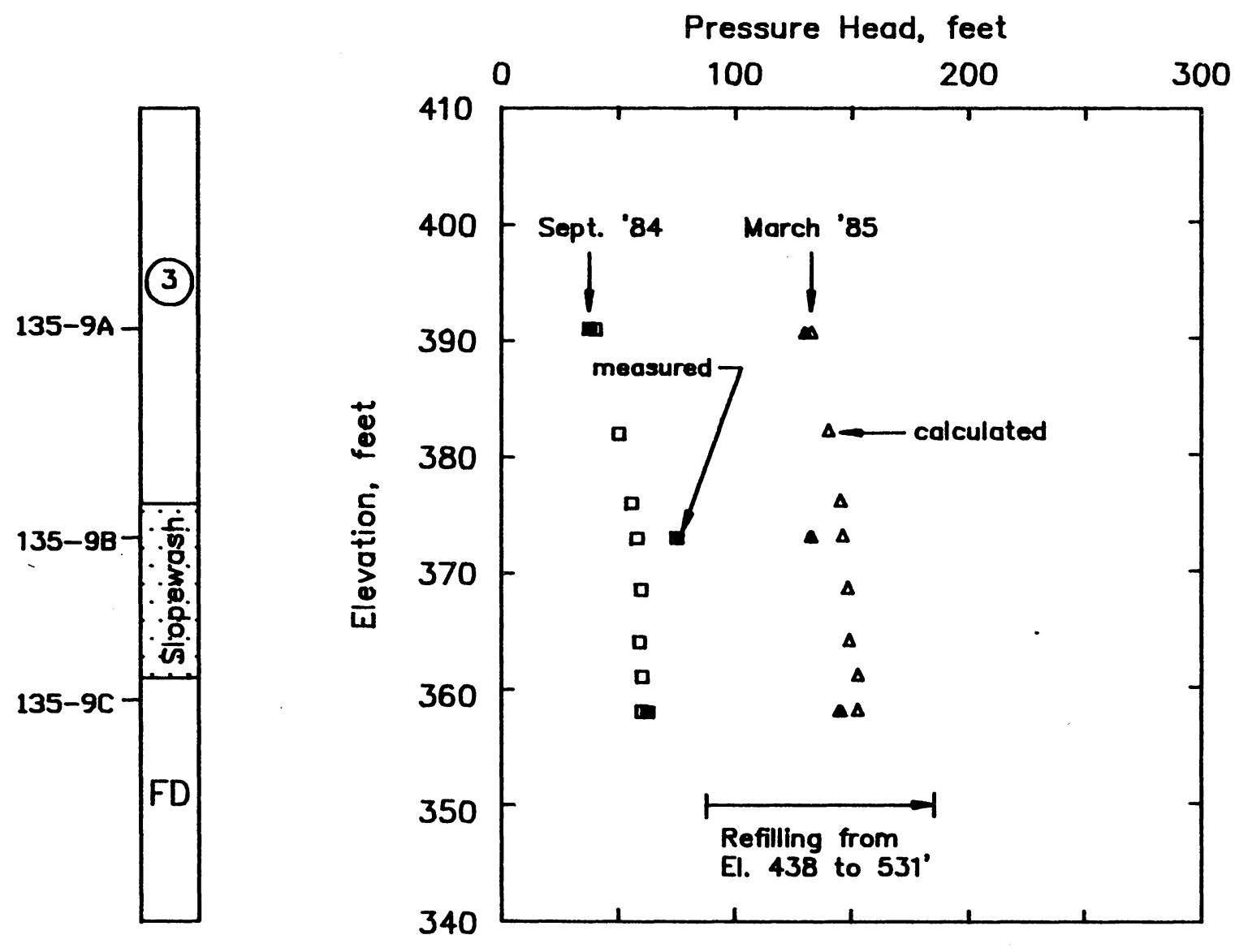

Figure 4-18 Comparison of Measured Heads at Piezometer 135-9 During 1984-85 Filling, With Values

Calculated Using Initial Soil Properties 


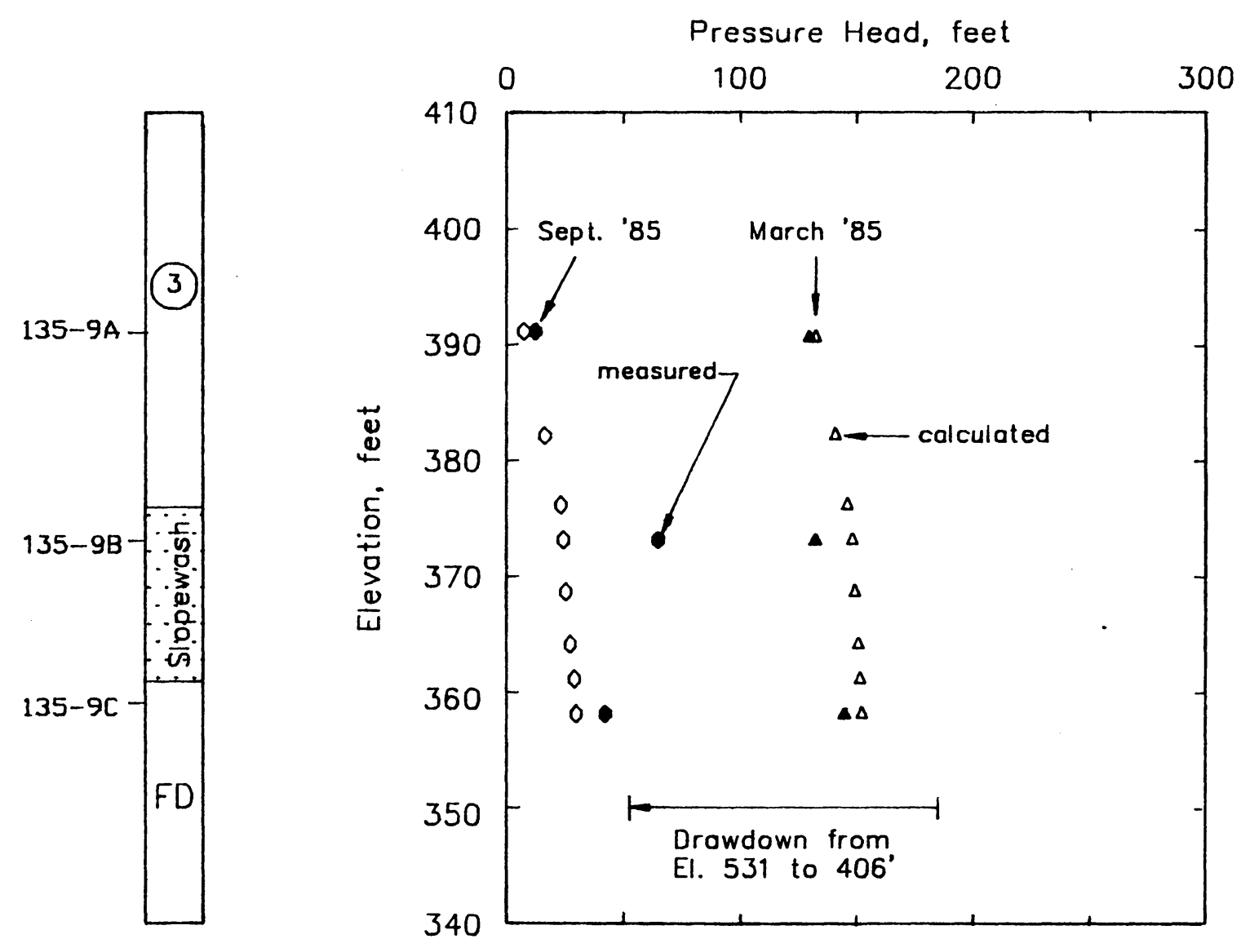

Figure 4-19 Comparison of Measured Heads at Piezometer 135-9 During 1985 Drawdown, with Values

Calculated Using Initial Soil Properties 


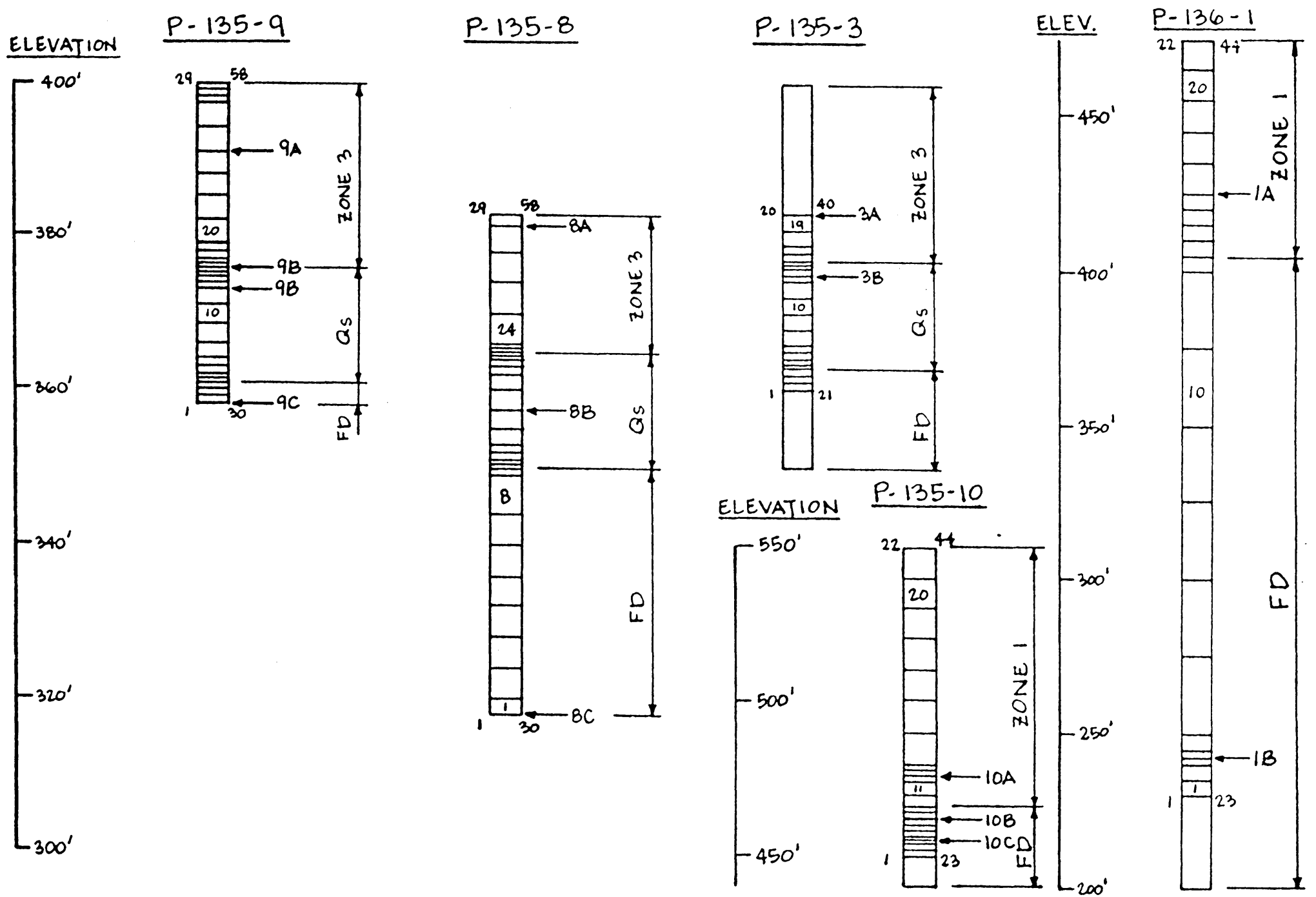

$\stackrel{\leftrightarrow}{\circ}$

Figure 4-20 One Dimensional Finite Element Meshes used for Analyses of Seepage at Piezometer Locations 
study are shown in Table 4-6.

From Table 4-6 it can be seen that only the vertical saturated permeability, $\mathrm{Kv}$, and the specific storage, Ss, significantly influenced the pore pressures calculated using UNSATl. Sixteen different combinations of $\mathrm{Ss}$ and $\mathrm{KV}$ were examined to achieve good agreement between the calculated and measured pore pressures during the 1984 drawdown, the 1984-85 filling and the 1985 drawdown. The degree of agreement finally achieved is shown in Figures 421, 4-22 and 4-23. The soil properties used in the final analyses, referred to as the calibrated soil properties, are listed in Table 4-4.

Piezometers $135-8 \mathrm{~B}$ and $135-3 \mathrm{~B}$ were also located in the slopewash. The soil properties determined from the calibration analyses for piezometer 135-9B were used for analyses of the conditions at these other two piezometers to determine if the same properties and boundary conditions would provide agreement between calculated and measured heads at these locations. The column meshes used to represent the piezometers are shown in Figure 4-20. The calculated and measured responses for piezometers 135-8 and 135-3 are shown in Figures 4-24 and 4-25. From Figure 4-24 it may be seen that the pressure heads calculated using the calibrated soil properties and boundary conditions were in excellent agreement with the measured values. It was 
TABLE 4-6 - Results of a Parametric Study on the Seepage Properties of the Slopewash

\section{Soil Property}

Vertical Saturated Permeability, Kv

feet/year

Horizontal Saturated Permeability, $\mathrm{Kh}$

feet/year

Porosity

Specific

Storage, Ss

$1 /$ feet

Relative Permeability Relationship

Pressure Head

Relationship

Initial Suction

Head

feet
Effect on Calculated Pore Pressures

Decreasing $\mathrm{KV}$ increased the pore pressure lag

No effect; predominantly vertical flow

No effect

Increasing Ss increased the pore pressure lag

No effect

No effect

No effect 


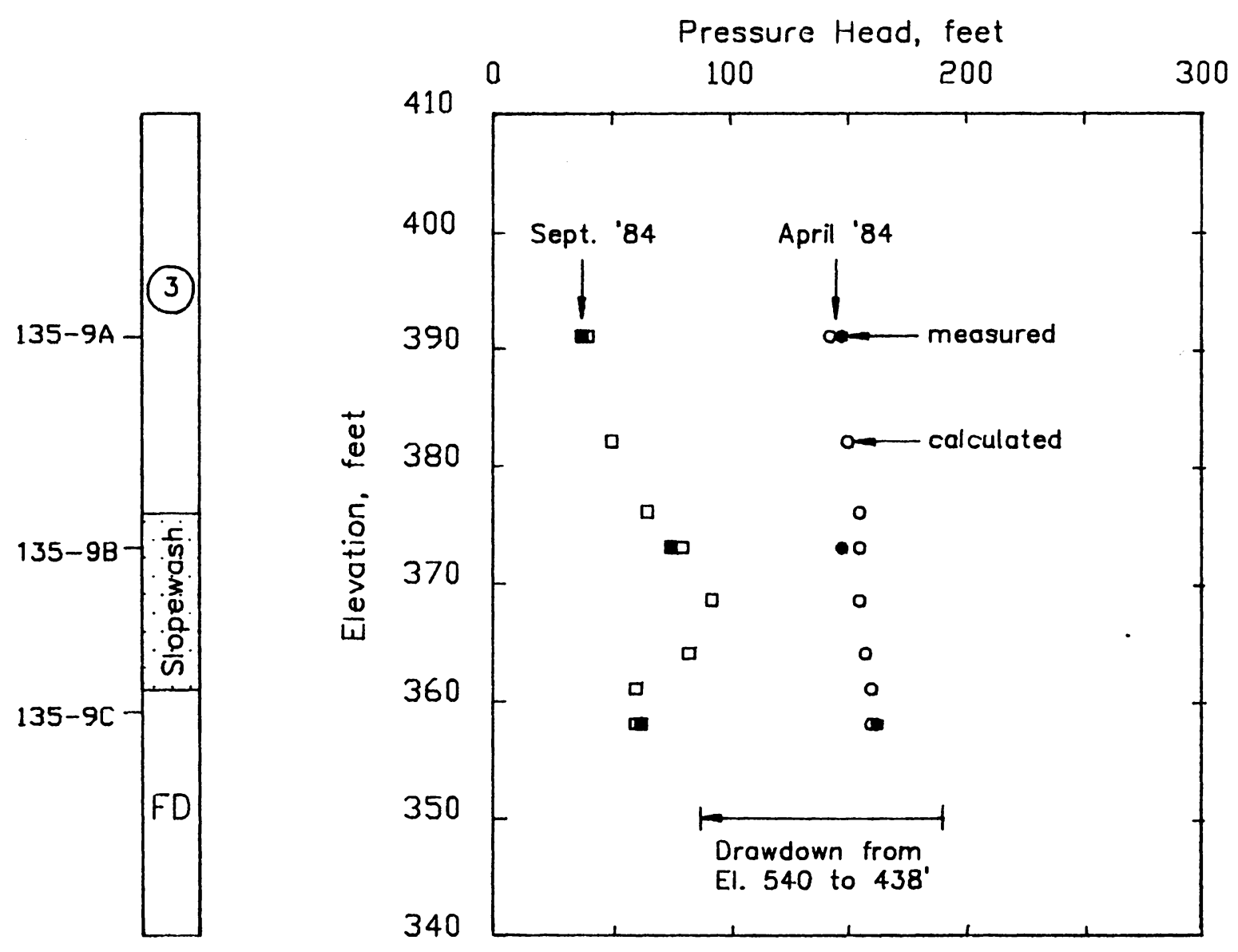

Figure 4-21 Comparison of Measured Heads At Piezometer 135-9 During 1984 Drawdown, with Values

Calculated Using Calibrated Soil Properties 

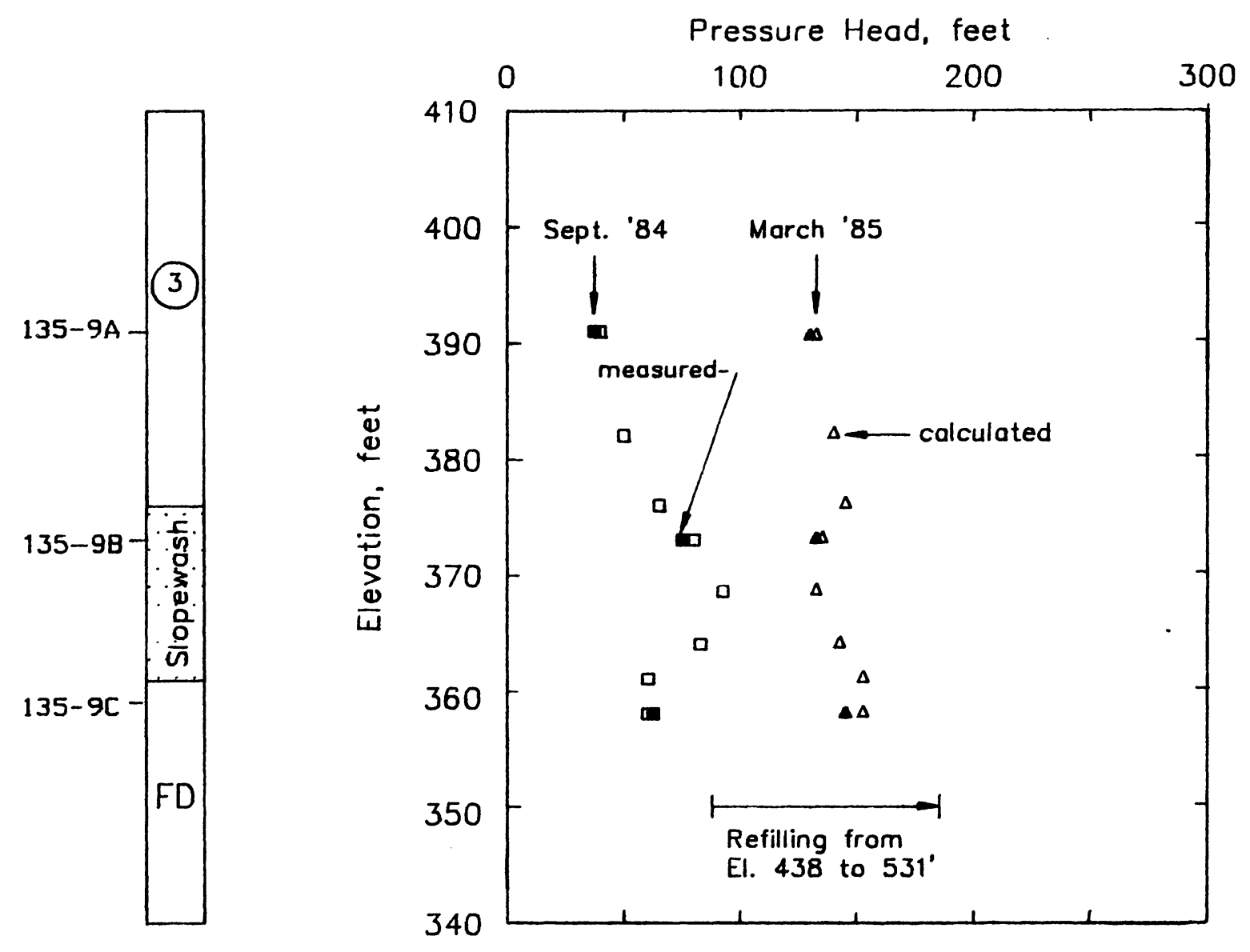

$\stackrel{\bullet}{\infty}$

Figure 4-22 Comparison of Measured Heads at Piezometer 135-9 During 1984-85 Filling, with Values Calculated Using Calibrated Soil Properties 


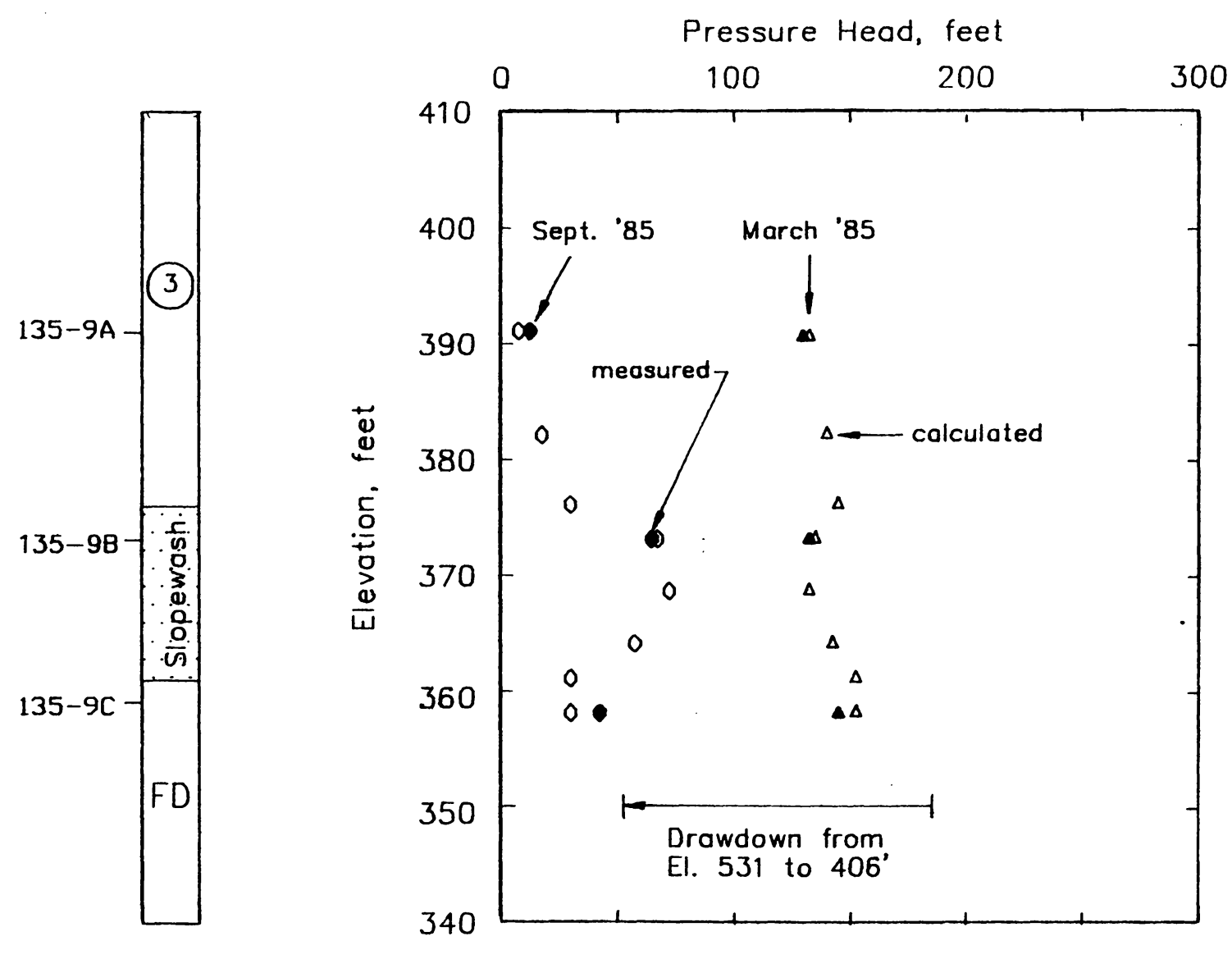

Figure 4-23 Comparison of Measured Heads at Piezometer 135-9 During 1985 Drawdown, with Values

Calculated Using Calibrated Soil Properties 


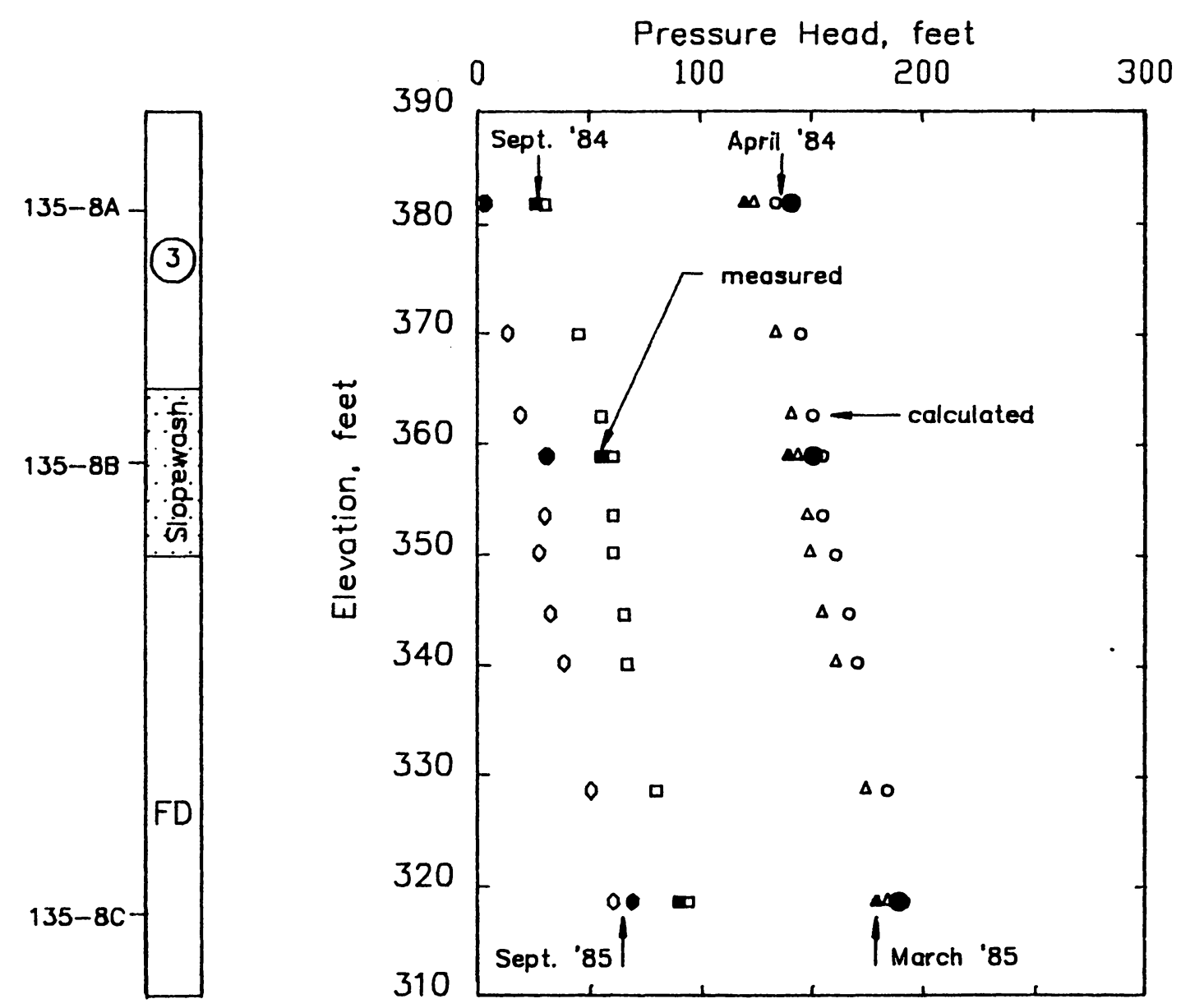

Figure 4-24 Comparison of Measured Heads at Piezometer 135-8 with Values Calculated Using Calibrated Soil Properties 


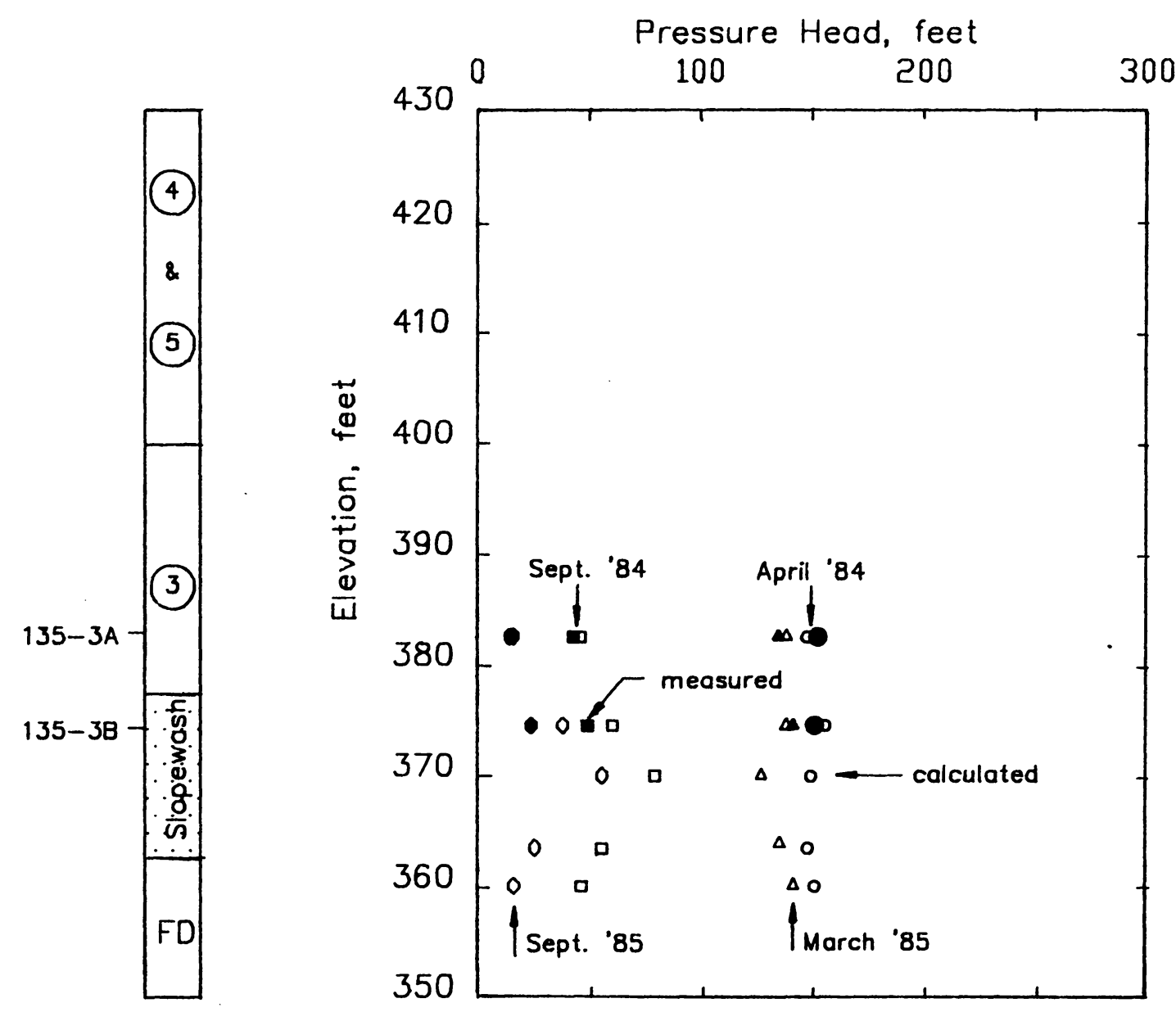

占

Figure 4-25 Comparison of Measured Heads at Piezometer 135-3 with Values Calculated Using Calibrated Soil Properties 
therefore concluded that these properties and boundary conditions were appropriate for analysis of time lag in the slopewash.

The analysis of piezometer $135-3$ performed using the calibrated soil properties overestimated the pore pressures by a maximum of 10 to 15 feet at the end of the 1984 and 1985 drawdowns as shown in Figure 4-25. No piezometer had been installed in the foundation at $135-3$, so the foundation boundary condition at 135-9, the closest piezometer, was used in the input. In an effort to improve the match the foundation boundary condition was varied from the piezometer 9C value of 20 feet below reservoir to 30 , 40, and 50 feet below the reservoir. The calculated pore pressures were not significantly affected by this change. Therefore the boundary condition at 135-9C was applied in the foundation at $135-3$ and it was concluded that the results obtained previously were as good as could be achieved.

Piezometer $136-1 \mathrm{~A}$ is located in the Zone 1 material. The Bureau of Reclamation had measured the value of $\mathrm{KV}$ for this material and only the specific storage had been varied to obtain a match between the observed and measured pore pressures. A specific storage of 0.000025 per foot produced excellent agreement between the calculated and measured values, as shown in Figure 4-26. 


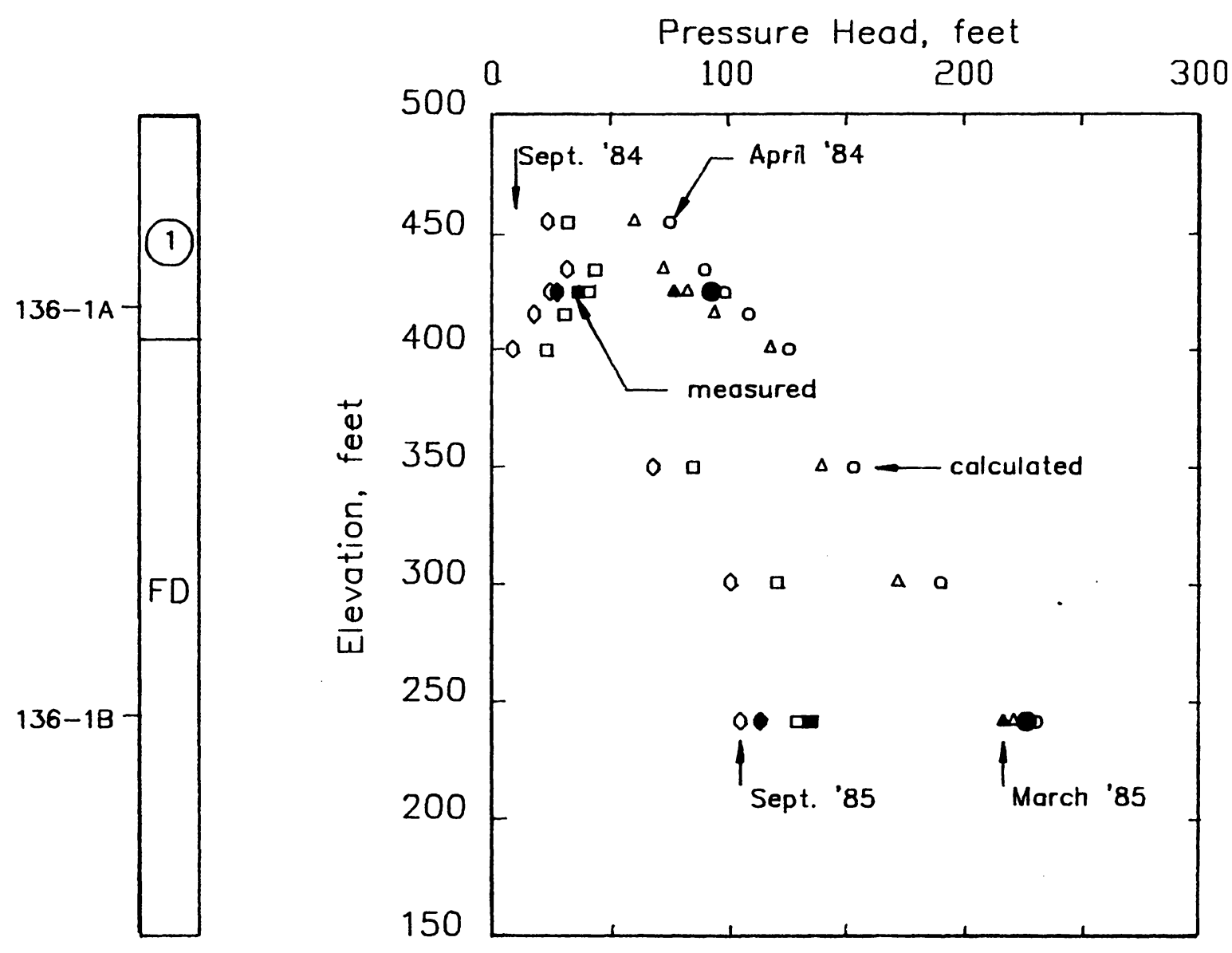

Figure 4-26 Comparison of Measured Heads at Piezometer 136-1 with Values Calculated Using Calibrated Soil Properties 
In summary, the soil properties that resulted in agreement between calculations and field data for piezometer $135-9 B$ also resulted in good agreement for the other piezometers located in the slopewash. As a result, the calibrated properties shown in Table 4-4 and the boundary conditions shown in Table 4-5 were used to calculate the pore pressures in the slopewash during the 1981 drawdown and at the time of the slide.

\section{Calculated Pore Pressures in the Slopewash}

The pore pressures in the slopewash were calculated using UNSATI and the finite element mesh shown in Figure 48. The boundary conditions determined from the piezometer measurements were applied at the locations of the solid dots. Since piezometers $135-3$ and $135-9$ were located only 13 feet apart and their boundary conditions were nearly identical, the 135-9 boundary conditions were used to represent both piezometers. The actual reservoir history leading up to the 1981 slide was approximated using 36 points as shown in Figure 4-3. Head boundary conditions corresponding to this history were applied at each of the upper nodes of the finite element mesh.

The 1981 slide plane passed through the slopewash at a depth of 1 to 5 feet. The pore pressures calculated at the middle and top of the slopewash thus provided an upper and 
lower bound on the pore pressures at failure. Figures 4-27 and 4-28 show the reservoir history employed in the analyses together with the pore pressures calculated at the top of the slopewash (node 83) and middle of the slopewash (node 82) at piezometer 135-9. The pore pressures at the top of the slopewash change quickly with reservoir fluctuations and are slightly lower than the reservoir except during long and rapid drawdowns. At the time of the 1981 slide the calculated pore pressures at the top of the slopewash are about 20 feet higher than the reservoir. At the middle of the slopewash, Figure 4-28, the pore pressures at the time of the slide are about $80 \mathrm{ft}$. higher than the reservoir.

The calculated pore pressures at the time of the 1981 slide at the top and middle of the slopewash are plotted in Figures 4-29 and 4-30. It may be noted that there is an area of exceptionally high pore pressures at the downstream end of the slopewash, where the slopewash is covered by the Zone 1 material. This region of high pore pressure is probably due to the pore pressures being trapped underneath the impermeable core and only being able to drain into the foundation. By comparing Figures 4-29 and 4-30, the difference between the calculated pore pressures at the top and middle of the slopewash is seen to be about 25 to 30 feet on the average, with the difference increasing sharply 


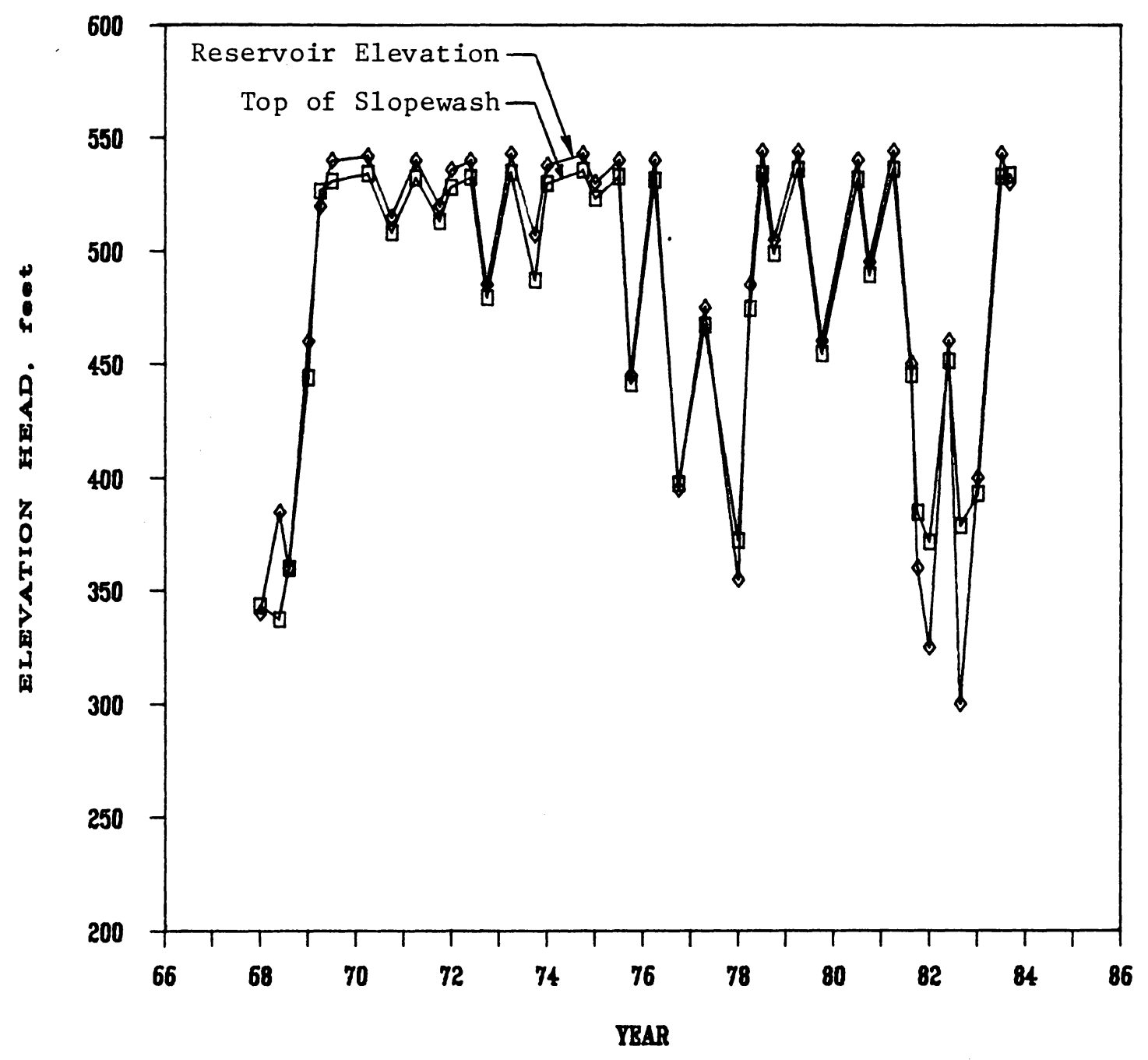

Figure 4-27 Calculated Pore Pressures at Top of Slopewash 


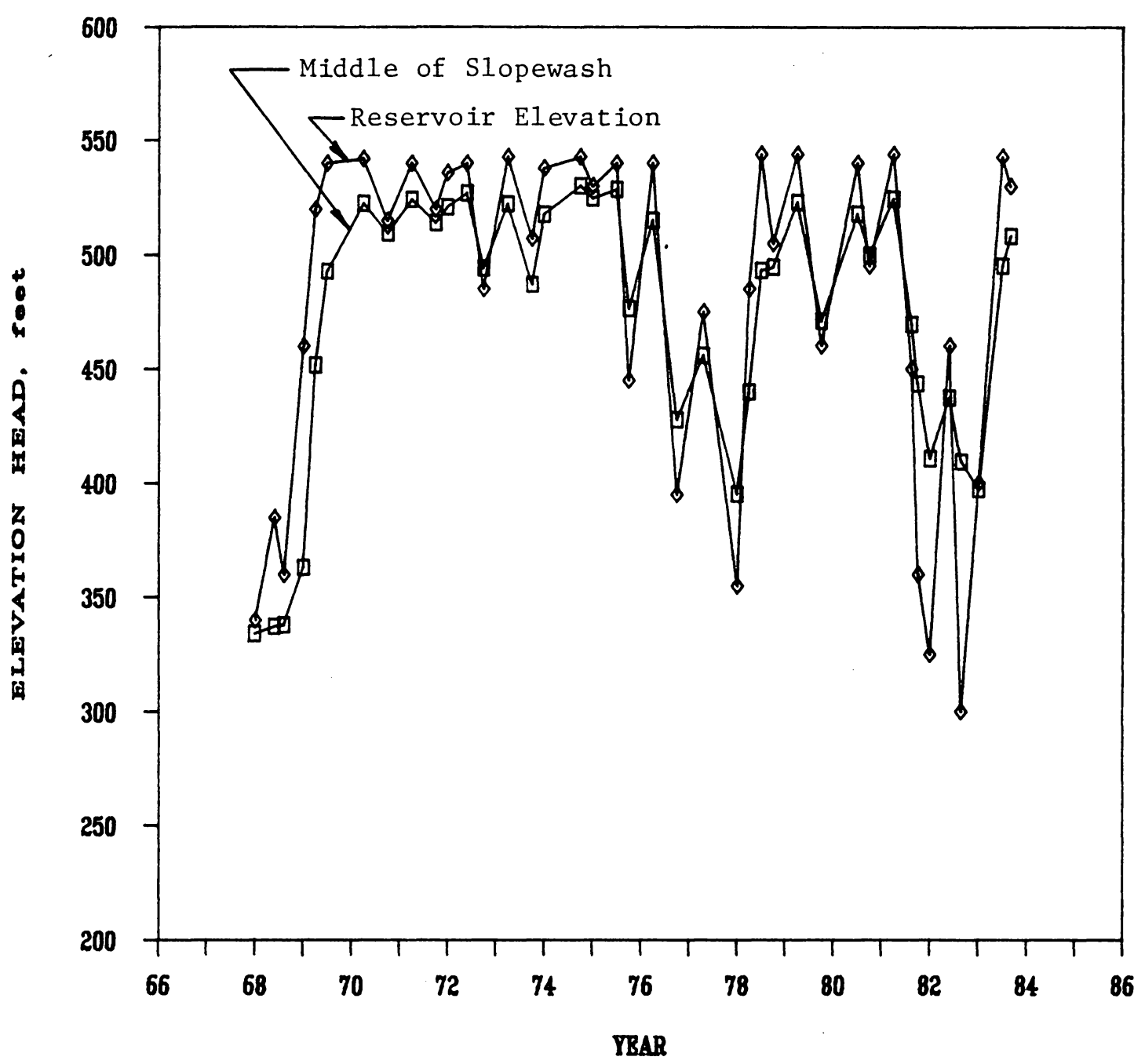

Figure 4-28 Calculated Pore Pressures at Middle of Slopewash 


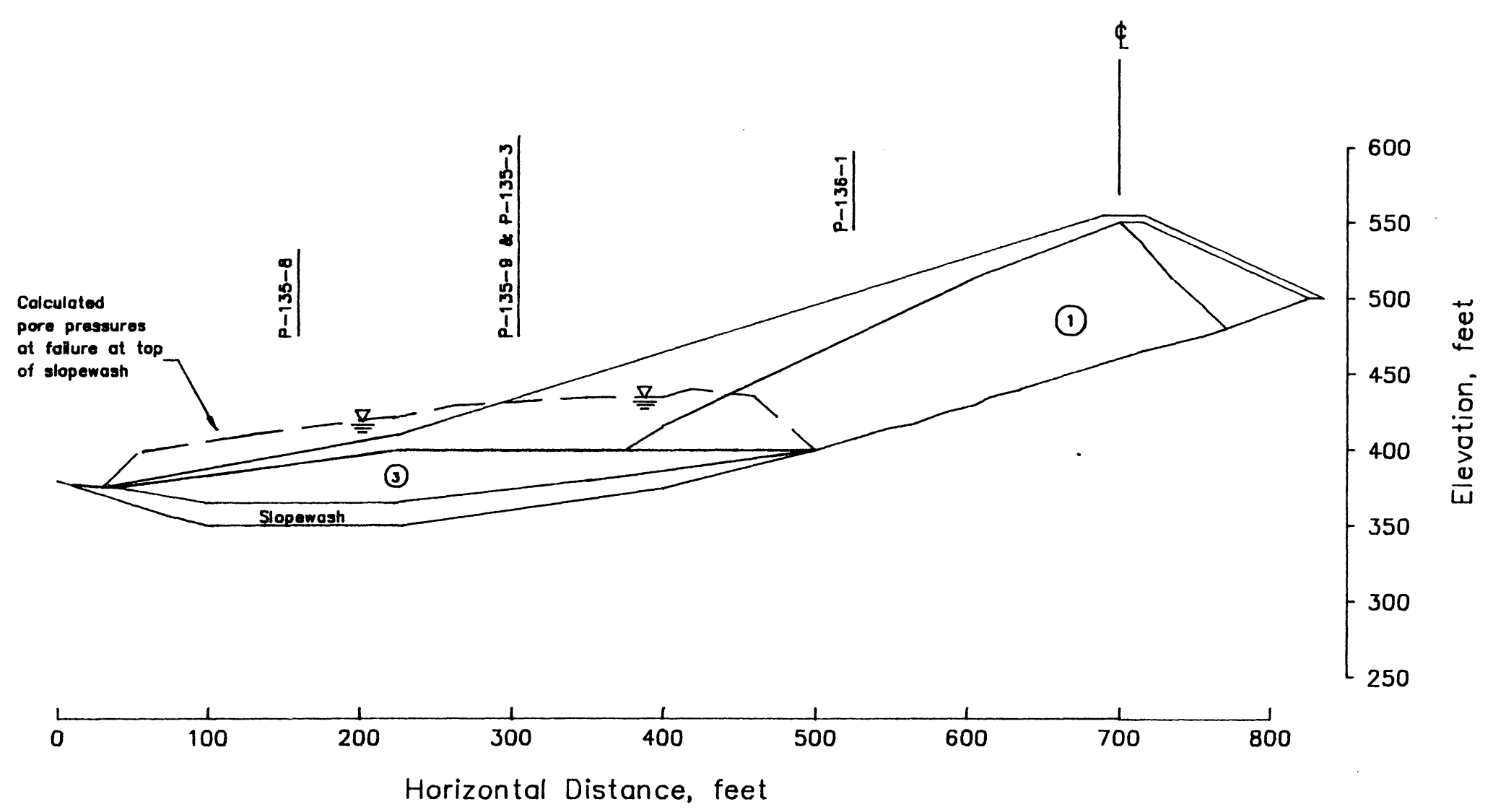

Figure 4-29 Calculated Pore Pressures at Top of Slopewash At the Time of the 1981 Slide 


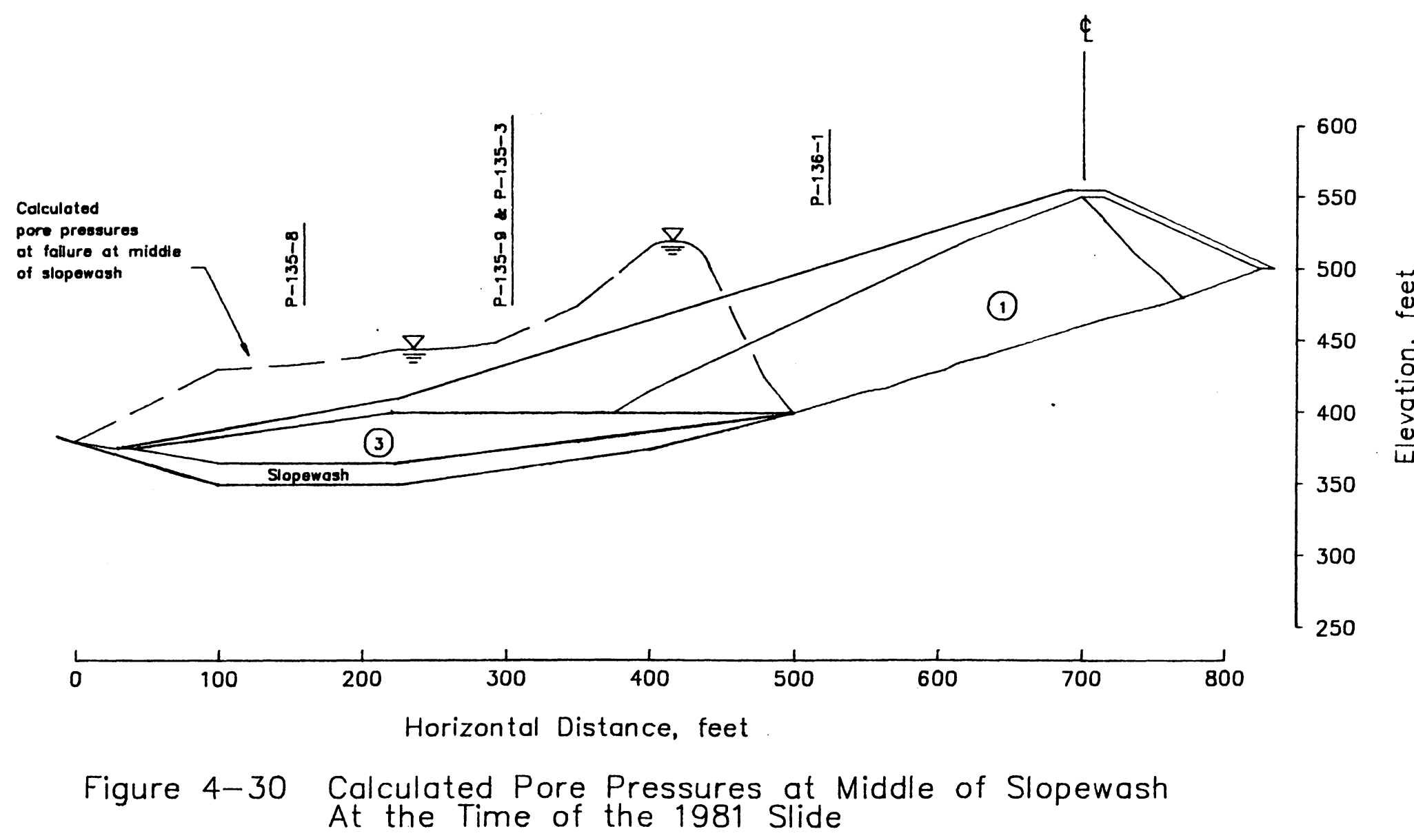


to as much as 80 to 90 feet as the slopewash tapers out under the clay core.

During the design of the stabilizing berm, the Bureau of Reclamation, (1984), used three different pore pressure assumptions in their slope stability analyses. These are shown in Figure 4-31. The Bureau's maximum and intermediate pore pressure assumptions correspond roughly to the pore pressures calculated at the middle and the top of the slopewash, discussed in the preceding paragraphs. Although no pore pressures that low were calculated, the Bureau's minimum pore pressure assumption was adopted to extend the range of pore pressures considered for reanalysis of the 1981 slide. The three pore pressure distributions used in these reanalyses are shown in Figure 4-32. The upper two are based on the seepage analyses described above and the lower one corresponds to the Bureau's minimum pore pressure assumption.

A fairly large part of the slide plane passed through the Zone 1 material and the pore pressures on the slide plane in this location are also important. The pore pressures in this area at the time of the 1981 slide were calculated using the $z$ one 1 mesh and the calibrated soil properties. The calculated pore pressures in the core, which were used for the reanalysis of stability, are shown 


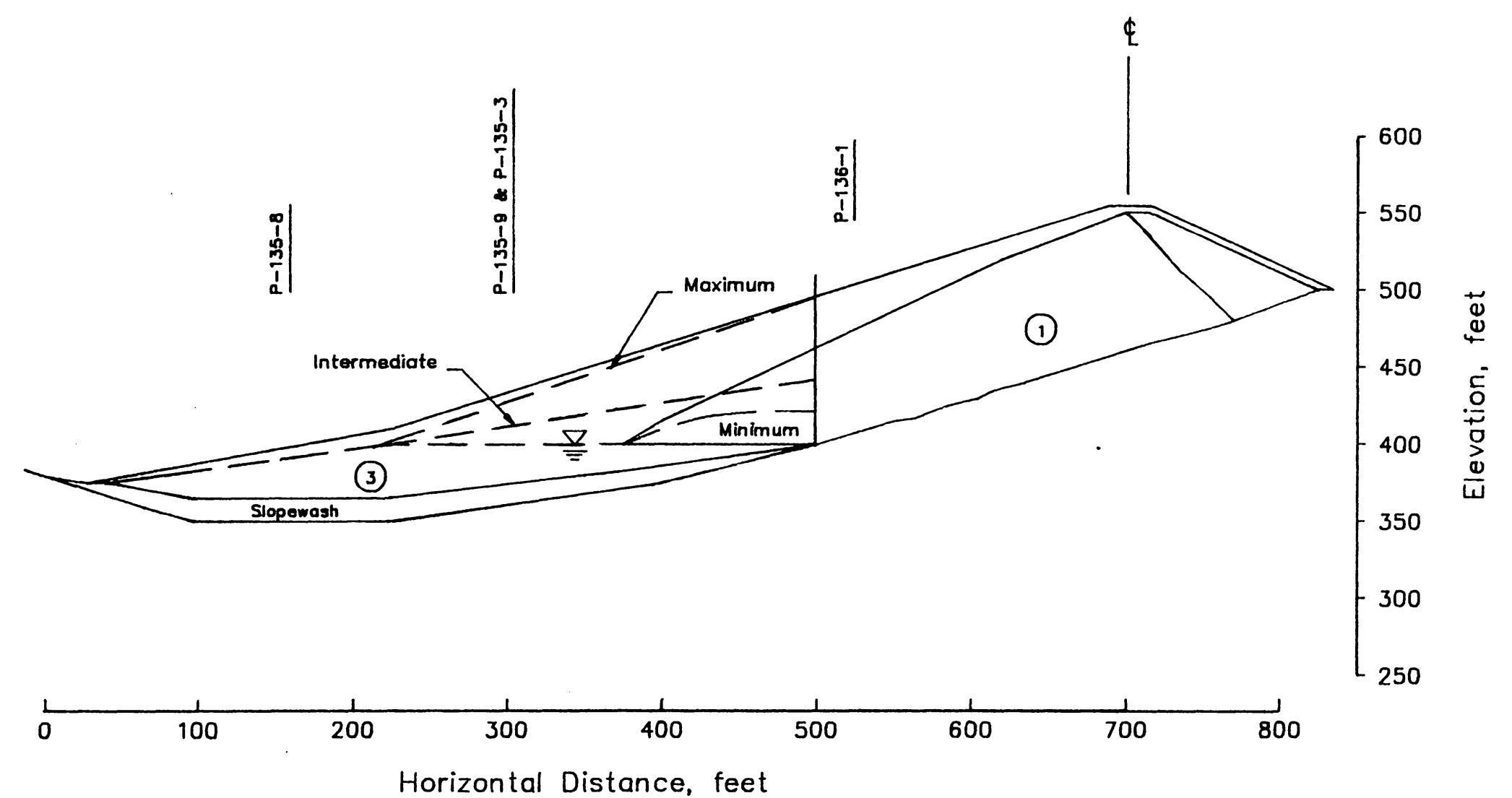

Figure 4-31 Pore Pressure Distributions in the Slopewash Used by the Bureau of Reclamation (1984) for Analysis of the 1981 Slide 


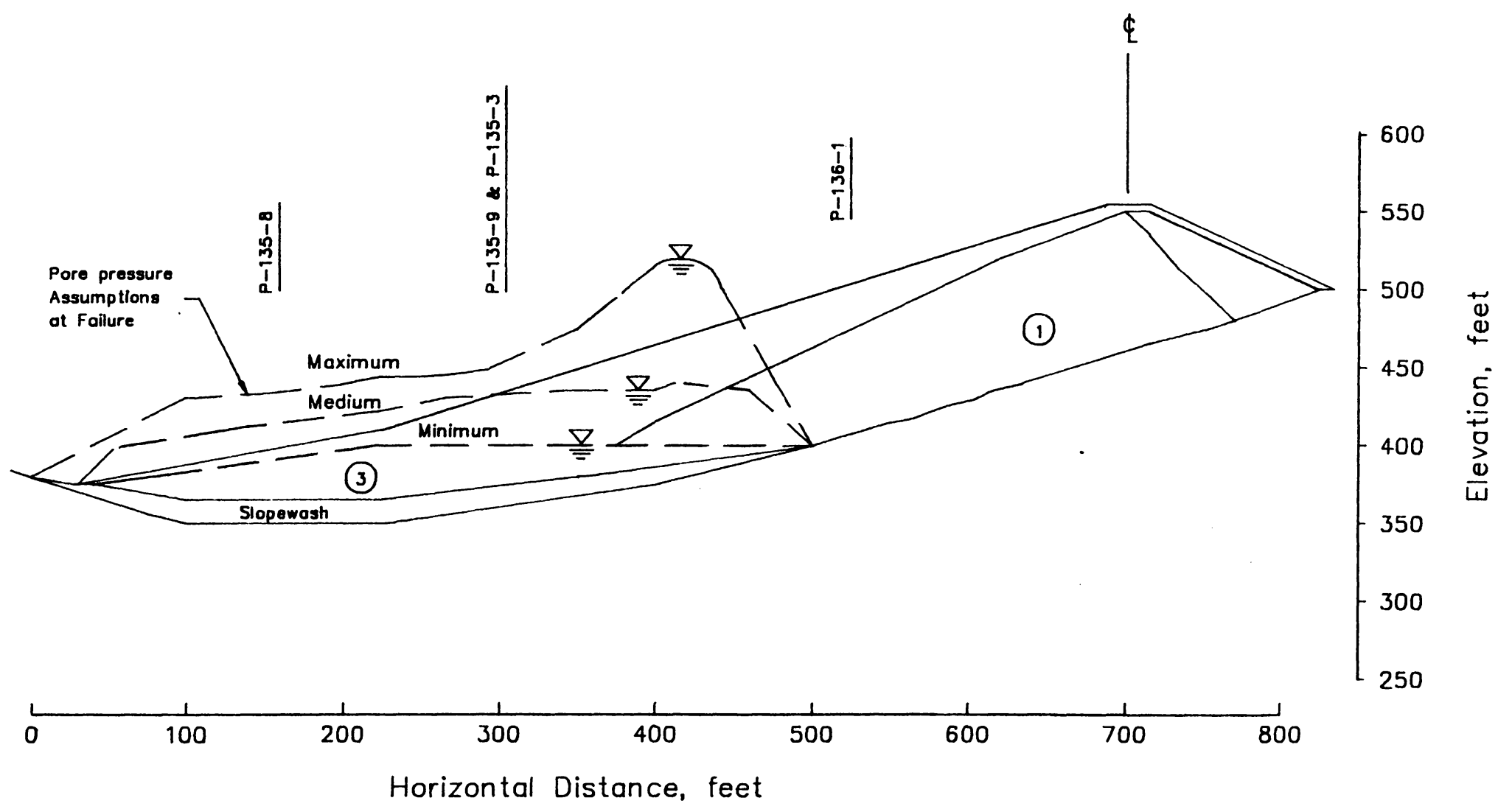

Figure 4-32 Pore Pressures in the Slopewash Used for Reanalyses of Stability 
in Figure $4-33$.

\section{Migration of Phreatic Surface}

A second objective of the seepage analyses was to determine the rate of advancement of the phreatic surface through the clay core. To achieve this objective the seepage through the core was analyzed using UNSATl together with the calibrated soil properties listed in Table 4-4, the boundary conditions listed in Table 4-5, and the zone 1 mesh shown in Figure 4-10. The appropriate boundary conditions were applied at the solid dots shown in the mesh and at the nodes along the upstream face of the mesh.

An interesting set of boundary conditions was applied at piezometer 135-10. The response at this location during the 1984 and 1985 drawdowns is shown in Figure 4-34. Piezometers $135-10 \mathrm{~B}$ and $10 \mathrm{C}$ are both located in the foundation and show a pressure head varying from 0 to -20 ft. From these values it appears the foundation drains all pore pressures when the reservoir is at or above the level of the piezometer. Also, it appears the piezometers can only function to a suction of $20 \mathrm{ft} .$, at which time cavitation occurs. A boundary condition varying from 0 to -20 feet, depending on the elevation of the reservoir, was applied at the corresponding nodes 132 and 133 to represent this response. 


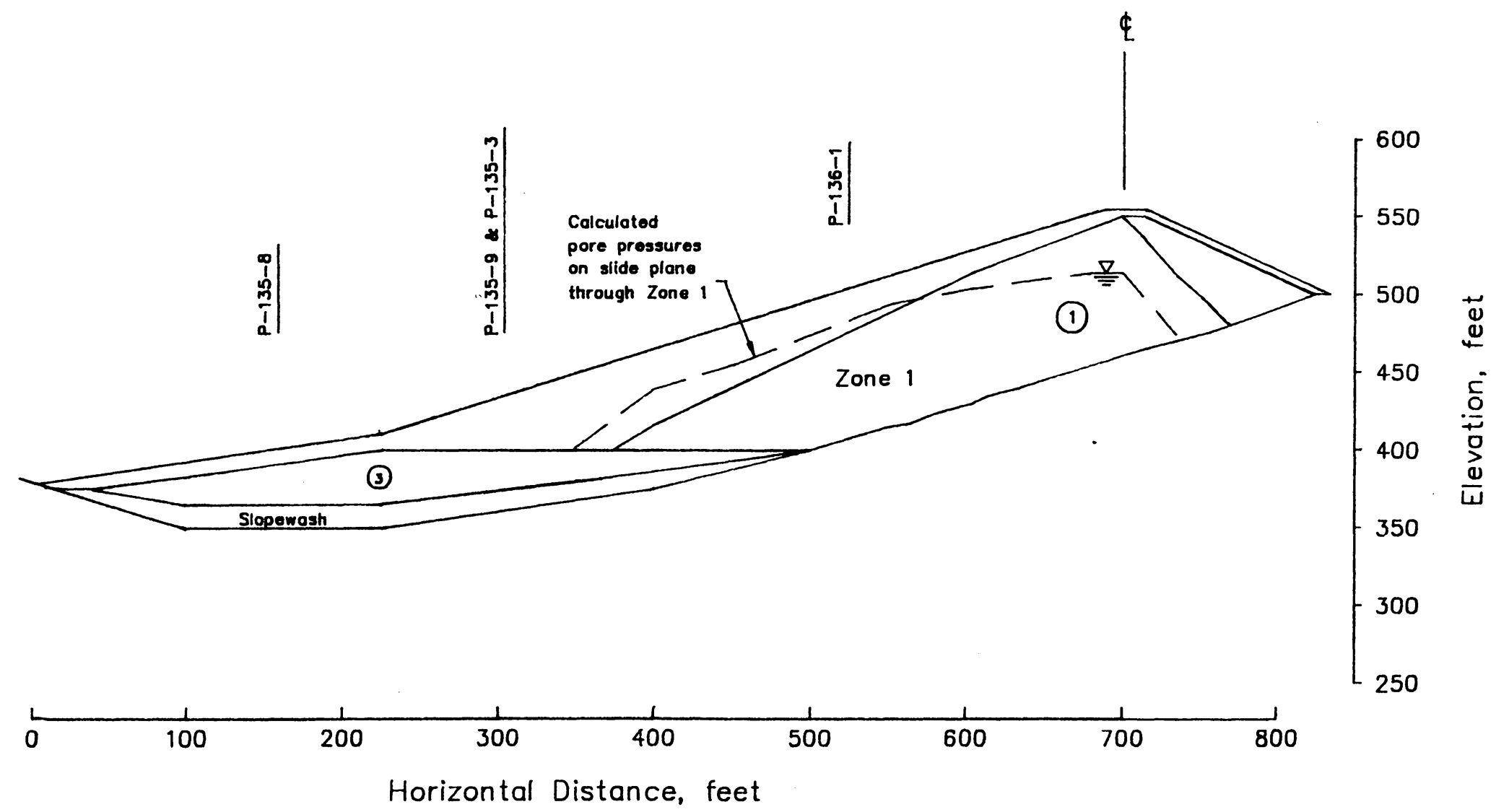

Figure 4-33 Pore Pressures in Zone 1 Used for Reanalyses of Stability 


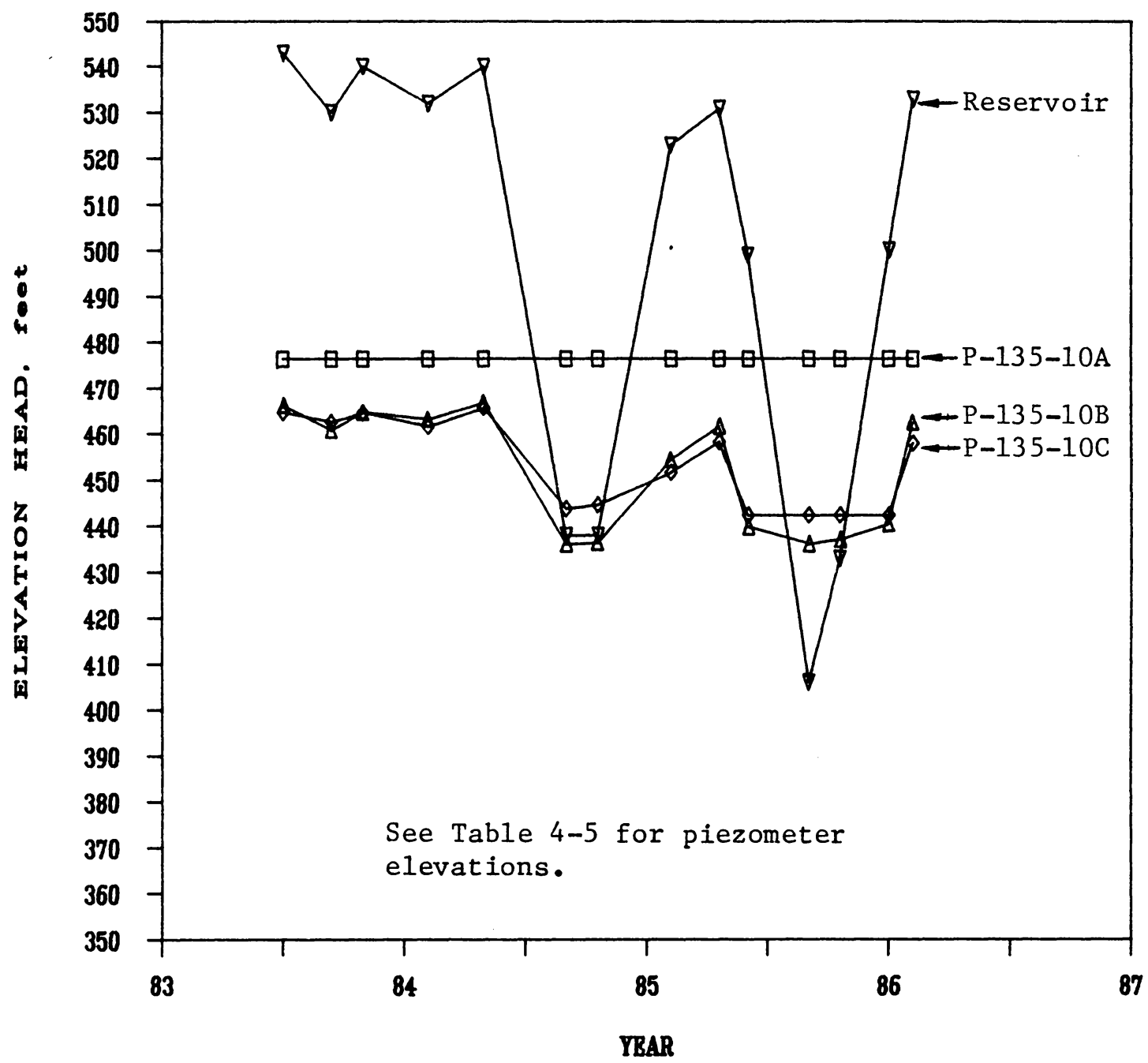

Figure 4-34 Variations of Heads with Time at Piezometers 135-10A, B, and C 
Piezometer 135-10A showed no response. It is believed that this is due to one of the following: 1) the piezometer is not functioning or 2) positive pore pressures have not yet developed at the piezometer location. Initially, it was assumed that positive pore pressures had not developed at the location of 135-10A. Therefore, in the analyses a boundary condition of zero pressure head was applied at all times at the corresponding node 134 .

The migration of the phreatic surface through the embankment is shown by the zero-pressure contours (the phreatic surfaces) in Figure 4-35. It may be seen that the phreatic surface advanced quickly through the clay core during the first few years the reservoir was full. The high permeability of the foundation materials and the reservoir being maintained at or near capacity during the first seven years were the main factors contributing to the rapid advancement.

From Figure 4-35, it appears that piezometer 135-10A might have been malfunctioning because the seepage in the core appears to have reached a nearly steady condition very quickly. To determine what effect this would have, the analysis was rerun with no boundary condition applied at node 134, i.e. piezometer 135-10A. This change did not affect the results.

In most soils a steady flow condition can be reached 


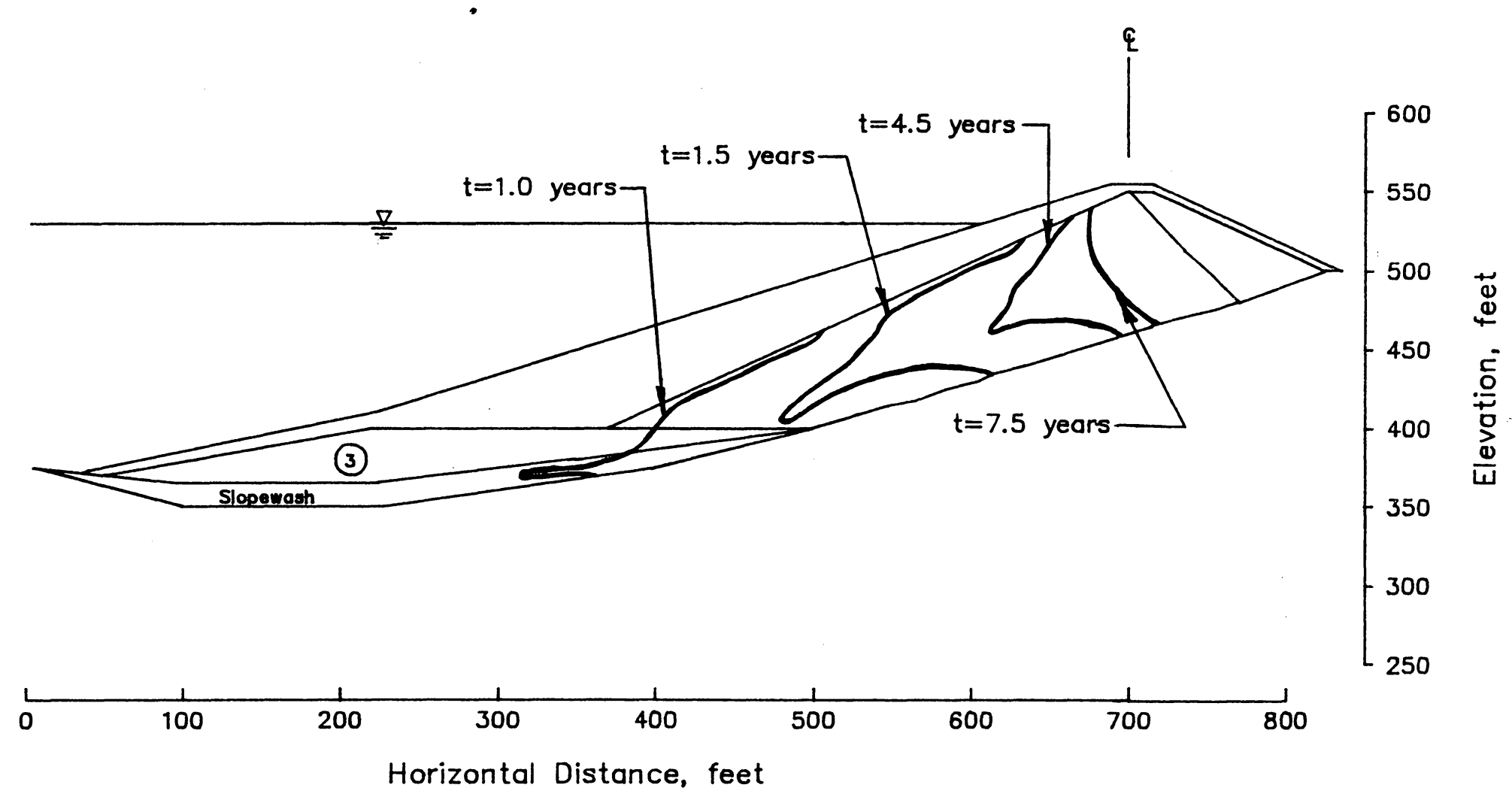

Figure 4-35 Migration of Phreatic Surface at Station $135+00$ 
before a soil is completely saturated. Based on the results in Figure 4-35, it appears a nearly steady flow condition developed during the first 8 years the reservoir was in operation and only the lower portions of the core, if any, became completely saturated during the 14 year history of the reservoir.

\section{Summary}

The main objectives of the transient seepage analyses were to determine 1) the pore pressures in the slopewash and clay core at the time of the 1981 slide and 2) the rate of migration of the phreatic surface through the core. These objectives were attained using finite element analyses of the non-steady seepage in the embankment. The parameters and boundary conditions used in the analyses were calibrated using piezometer data recorded from February, 1984 to February, 1986.

Because the slide plane passed through the top half of the slopewash deposit, the pore pressures calculated at the middle and top of the slopewash were used together with the minimum pore pressure assumptions of the Bureau of Reclamation to establish maximum, medium and minimum slopewash pore pressures at the time of the 1981 slide. The resulting range of pore pressures in the slopewash at failure is shown in Figure 4-32. These pore pressures were 
used in the slope stability and stress-deformation finite element analyses.

A second objective of the seepage analyses was to determine the rate of advancement of the phreatic surface through the embankment. These results, shown in Figure 435 , indicate that the phreatic surface advanced quickly and that the core reached a nearly steady flow condition within 8 years. The time to reach a neatly steady state was reduced by the high foundation permeability and by the reservoir being maintained at or close to capacity during its first 8 years. It is believed that only the lower portion of the core became completely saturated during this period. 


\section{CHAPTER FIVE - Analyses of the Stability of the Opstream Slope of San Luis Dam}

As shown in Chapter 3 , the drained shear strength of the slopewash material beneath the upstream slope of San Luis Dam was reduced very significantly when the material was wetted. This reduction in shear strength of the slopewash would be accompanied by a reduction in the factor of safety of the upstream slope, and it is thus of considerable interest to know the factor of safety of the upstream slope before and after wetting.

The laboratory testing program has shown that the slopewash undergoes a further reduction in strength when subjected to large shearing deformations. At large shear displacements, the shearing resistance is reduced from the fully softened peak strength to the residual shear strength. The current state-of-the-art of design of slopes in stiff fissured clays and shales, based on the pioneering work of Skempton $(1964,1977)$ indicates that slopes in stiff fissured clays should be designed using the fully softened peak strength for conditions where there has been no previous slide, as at San Luis Dam. It is therefore of considerable interest to determine whether the use of the fully softened peak strength for the drawdown condition would have resulted in a factor of safety equal to one for the upstream slope of San Luis Dam, or whether a further 
decrease in strength below the fully softened peak in fact was responsible for the failure.

The stability analyses described in this chapter were performed to investigate these questions. A considerable number of analyses of the upstream slope, for a great variety of conditions, have been performed previously by Morfitt (1982) and Von Thun, et al. (1984), in connection with the Bureau of Reclamation study of the slide and the design of the berm that was built to stabilize it. Insofar as the conditions analyzed were the same, the results described in this chapter are in good agreement with the results of these previous analyses by the Bureau of Reclamation.

\section{Cross Section Analyzed}

The analyses described herein were performed for the principal section through the slide, Station $135+00$, which is shown in Figure 5-1. The slip surface shown in Figure 5-1 was established in the field by slope indicator measurements, and by surface observations at the top and the bottom of the slide.

It may be noted that the slip surface passes through the core of the dam (zone 1) and down into the underlying slopewash material within the foundation, and then outward toward the toe of the dam. Measurements in slope 

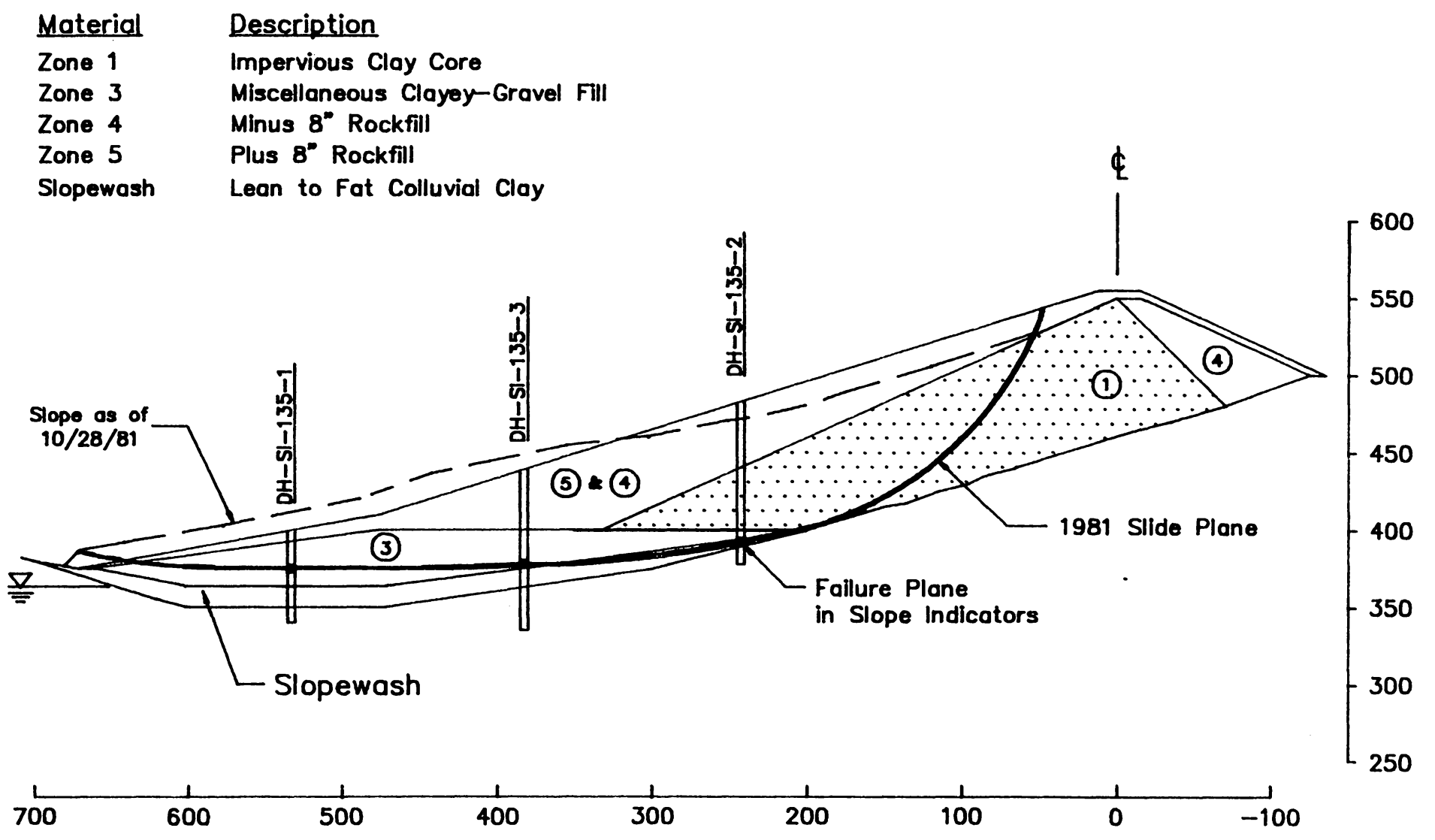

Horizontal Distance, feet

Figure 5-1 Estimated Upstream Slide Plane at Station $135+00$ 
Indicators DH-SI-135-1 and DH-SI-135-3 indicated that the slip plane passed through the miscellaneous clayey gravel zone rather than the slopewash at those locations. Because the boundary between the slopewash and the overlying clayey gravel undulates somewhat, it seems possible that the length of the slip surface located within the slopewash might be somewhat more or less than shown in Figure 5-1. Even so, since the shear strength.of the clayey gravel is very nearly equal to the fully softened shear strength of the slopewash, the calculated value of the factor of safety for the fully softened condition is not very sensitive to the length of the slip surface within the slopewash or the clayey gravel. The factors of safety discussed in subsequent sections were all calculated using the slip surface shown in Figure $5-1$.

\section{Shear Strength Parameters}

The shear strength parameter values used in the stability analyses are shown in Table 5-1. The values shown for the embankment zones $1,3,4$, and 5 are the same as those used by Von Thun, et al. (1984) for their analyses of the embankment, and were determined from the results of tests performed on materials from the $\mathrm{z}$ one 1 borrow area at the time the embankment was designed.

The strength parameters shown for the slopewash 
TABLE 5-1 - Moist Unit Weights and Drained Shear Strength Parameters for the San Luis Dam Embankment and Foundation Materials

Material

Zone 1

(Core)

Zone 3

(Miscellaneous)

Zones 4 and 5

(Rockfill shell)

Dry Slopewash

(Peak strength)

Soaked Slopewash

(Fully softened peak)

Soaked Slopewash

(Residual strength)
Unit Weight

130 pcf

$135 \mathrm{pcf}$

$140 \mathrm{pcf}$

$150 \mathrm{pcf}$

550 psf

390

125 pcf

0

250

125 pcf

0

150 
material are those determined from the tests described in Chapter 3. As discussed in that chapter, it may be seen that the peak shear strength of the slopewash is reduced very considerably by wetting, from $c^{\prime}=5500$ psf, $\phi^{\prime}=390$, to $c^{\prime}=0, \phi^{\prime}=250$. The latter value is the same as the "fully softened" peak, the peak strength of the slopewash when remolded.

When the slopewash is subjected to large shearing deformations, its shear strength is further reduced. As shown in Table 5-1, the residual shear strength of the slopewash measured at shear displacements of eight to ten inches corresponds to $c^{\prime}=0, \phi^{\prime}=150$.

\section{Calculated Factors of Safety}

The safety factor values for the upstream slope that were calculated using these shear strength parameters are shown in Table 5-2. The values shown in Table 5-2 were calculated using Spencer's (1967) procedure and stresses calculated by finite element analyses, both of which satisfy all conditions of equilibrium.

For the end of construction condition, with the slope still dry, the calculated value of the factor of safety was 4.0. With the reservoir full, and the slopewash fully wetted by the reservoir, the calculated value of factor of safety was 2.0 , only one-half of its value at the end of 
TABLE 5-2 - Calculated Factors of Safety for the Upstream Slope of San Luis Dam

Condition

End of Construction (Slopewash dry)

Reservoir Full (Slopewash wetted)

Reservoir Drawn Down (Fully softened peak strength in slopewash)

Reservoir Drawn Down (Fully softened peak strength in slopewash)

Reservoir Drawn Down (Residual strength in slopewash)
Method of Analysis

Spencer's method

Spencer's method

Finite Element Stresses

Spencer's method

1.31

Spencer's method

0.98
1.42

Factor of

Safety

3.98

2.01

Note: All factors of safety were calculated using the "medium" pore pressure condition determined from the transient seepage analyses described in Chapter 4. As shown in Chapter 4, this distribution is slightly higher than the maximum distribution considered by the Bureau of Reclamation, and is considered the best estimate of the actual pore pressures during the 1981 drawdown. 
construction. This large reduction in the calculated value of factor of safety illustrates the great importance of the strength of the slopewash to the stability of the upstream slope.

During the rapid drawdown of the reservoir that preceded the 1981 slide, there was insufficient time for complete dissipation of excess pore pressures within the slopewash. The studies described.in Chapter 4 indicated that the most likely distribution of excess pore pressures at the end of drawdown, called the "medium" distribution, was slightly higher than the maximum distribution used by Morfitt (1984) in previous studies of upstream slope stability. The values of factor of safety shown in Table 5-2 for the reservoir drawn down condition were calculated using this "medium" pore pressure distribution within the slopewash and $\mathrm{Z}$ one 3 .

It can be seen that the factor of safety calculated for the reservoir drawn down condition using spencer's method was 1.3 , and the value calculated using the shear and normal stresses from finite element analyses was 1.4. Although these two values of factor of safety are not in precise agreement, they do fall within \pm 5 percent from a central value, as Wright and Duncan (1980) indicated should be the case for methods that satisfy all conditions of equilibrium. 
It may thus be concluded that the best estimate of the factor of safety for the rapid drawdown condition, using the fully softened shear strength in the slopewash, is about 1.35. This is considerably greater than unity, and would likely be considered a fully acceptable value of safety for the severe rapid drawdown condition. In spite of the fact that the calculated factor of safety was considerably greater than unity, the upstream slope failed. This indicates that there was some significant difference between the conditions or the properties considered in the analyses and those that actually existed in the field. The most likely difference is believed to be that the shear strength of the slopewash material was smaller than the fully softened peak value, in spite of the fact that no previous slide had occurred at this location.

From Table 5-2 it can also be seen that the factor of safety calculated for the drawdown condition using residual strength in the slopewash was 0.98. Thus it is clear that the slide should have occurred only if the shear strength of the slopewash material was reduced below its fully softened value. What is not clear is why this should happen, since the studies performed by Skempton (1964, 1977) indicate that the shear strength mobilized in firsttime slides in stiff fissured clays should be the peak 
fully softened shear strength.

\section{Summary}

Analyses of the stability of the upstream slope of San Luis Dam show that the reduction of shear strength accompanying wetting of the slopewash by filling the reservoir caused a 50 percent decrease in the factor of safety, from 4.0 to 2.0 .

During rapid drawdown the factor of safety decreased further, as a result of removal of the stabilizing external water pressures on the slope, combined with incomplete dissipation of the excess pore pressures within the slope. The factor of safety calculated for this condition, using the fully softened peak strength within the slopewash, was about 1.35. Only by using a strength for the slopewash close to the residual value would it be possible to calculate a factor of safety equal to unity for the condition where failure actually occurred. Thus the failure of the upstream slope of San Luis Dam cannot be explained in terms of the previous finding by skempton (1964, 1977) that it is appropriate to use the fully softened peak strength for analyses of slope stability in stiff fissured clays where there has been no previous slide.

This finding is inconsistent with current 
understanding of the state-of-the-art regarding the shear strengths of stiff fissured clays, and required further investigation. The studies performed to investigate this seemingly anomalous result are explained in subsequent chapters. 


\section{CHAPTER SIX - Finite Element Analysis of Stresses}

in the Embankment and Foundation

\section{Introduction}

The finite element analyses described in this chapter were performed to determine the stresses in San Luis Dam at the end of construction and during operation with the reservoir empty and full. These stresses were used to determine the sequence of cyclic loading to which laboratory direct shear samples were subjected to simulate the stress changes leading up to the 1981 slide.

To accomplish this objective, finite element analyses were conducted using the hyperbolic model developed by Duncan, et al. (1980) to represent the stress-strain and strength characteristics of the slopewash and the embankment materials.

\section{Soil Properties for Analysis}

The values of the hyperbolic stress-strain parameters used to describe the upstream and downstream slopewash, which are shown in Table 6-1, were determined from the results of the laboratory tests described in previous chapters. The hyperbolic parameters used for the embankment materials were provided by the Bureau of Reclamation, (1985), and are shown in Table 6-2. 
TABLE 6-1 - Hyperbolic Stress-Strain Parameters for the Upstream and Downstream Slopewash

\begin{tabular}{|c|c|c|c|}
\hline $\begin{array}{l}\text { Hyperbolic } \\
\text { Parameter }\end{array}$ & $\begin{array}{c}\star \\
\text { Dry } \\
\text { Slopewash }\end{array}$ & $\begin{array}{c}\star \star \star \\
\text { Drained } \\
\text { Soaked } \\
\text { Slopewash } \\
\end{array}$ & $\begin{array}{r}\text { Undrained } \\
\text { Upstream } \\
\text { Slopewash } \\
\end{array}$ \\
\hline $\begin{array}{l}\text { Density } \\
(1 \mathrm{~b} / \mathrm{cu} \mathrm{ft})\end{array}$ & 150 & 125 & 125 \\
\hline $\begin{array}{l}\text { Cohesion } \\
(1 b / s q f t)\end{array}$ & 5500 & 0 & 1125 \\
\hline $\begin{array}{l}\text { Friction Angle } \\
\text { (degrees) }\end{array}$ & 39 & 25 & 10 \\
\hline $\begin{array}{l}\text { Modulus Numbers } \\
\text { Loading } \\
\text { Unloading }\end{array}$ & $\begin{array}{l}2000 \\
4500\end{array}$ & $\begin{array}{l}200 \\
450\end{array}$ & $\begin{array}{l}250 \\
500\end{array}$ \\
\hline Modulus Exponent & 0.6 & 0.6 & 0.09 \\
\hline Failure Ratio & 0.85 & 0.85 & 0.91 \\
\hline $\begin{array}{l}\text { Bulk Modulus } \\
\text { Number } \\
\text { Exponent }\end{array}$ & $\begin{array}{r}1950 \\
0.5\end{array}$ & $\begin{array}{l}195 \\
1.0\end{array}$ & $\begin{array}{l}350 \\
0.09\end{array}$ \\
\hline $\begin{array}{l}\text { Earth Pressure } \\
\text { Coefficient, } k_{0}\end{array}$ & 0.1 & 0.65 & 0.65 \\
\hline
\end{tabular}

* End of construction condition

** Reservoir full and reservoir drawn down conditions 

TABLE 6-2 - Drained Hyperbolic Stress-Strain Parameters
for the Embankment Materials *

Hyperbolic

parameter

Density

( $\mathrm{lb} / \mathrm{cu} \mathrm{ft}$ )

Cohesion

( $1 \mathrm{~b} / \mathrm{sq} \mathrm{ft}$ )

Friction Angle

(degrees)

Modulus Numbers

$$
\begin{aligned}
& \text { Loading } \\
& \text { Unloading }
\end{aligned}
$$

Modulus Exponent

Failure Ratio

Bulk Modulus

Number

Exponent

Earth Pressure

Coefficient, $k_{0}$
Drained

Zone 1

130

500

28.5

17

Drained

Zone 3

135

360

0

40

250

2000

0.2

0.78

223

0.03

99

200

450

900

0.7

0.37

0.86

0.61

$\begin{array}{rl}45 & 225 \\ 0 & 0.18\end{array}$

0.8

0.67

* Parameter values were supplied by the Bureau of Reclamation (1985). 
Drained parameters were used for all of the zones within the embankment for the analyses simulating construction of the embankment. It was decided to use drained parameters because 1) the slopewash was partly saturated and it was considered that any excess pore pressures within it would dissipate rapidly, 2) the clay core was compacted on the dry side of optimum and it was expected that pore pressures during construction would be very small, and 3) all of the other zones in the embankment and the foundation were sufficiently permeable so that they would be expected to drain rapidly.

\section{Analysis Procedures}

Figure 6-1 shows the finite element mesh used for the analyses of stresses and movements at Station 135+00. It may be noted that the slopewash was modeled using a single row of elements. To confirm the accuracy of this representation of the slopewash, a one dimensional analysis using one and five elements to represent the slopewash was conducted. The calculated stresses and displacements for the two meshes were very nearly equal and it was therefore concluded that the slopewash could be modeled with a single row of elements, using the mesh shown in Figure 6-1.

Drained analyses were used to calculate the stresses in the slopewash for the end of construction, the reservoir 


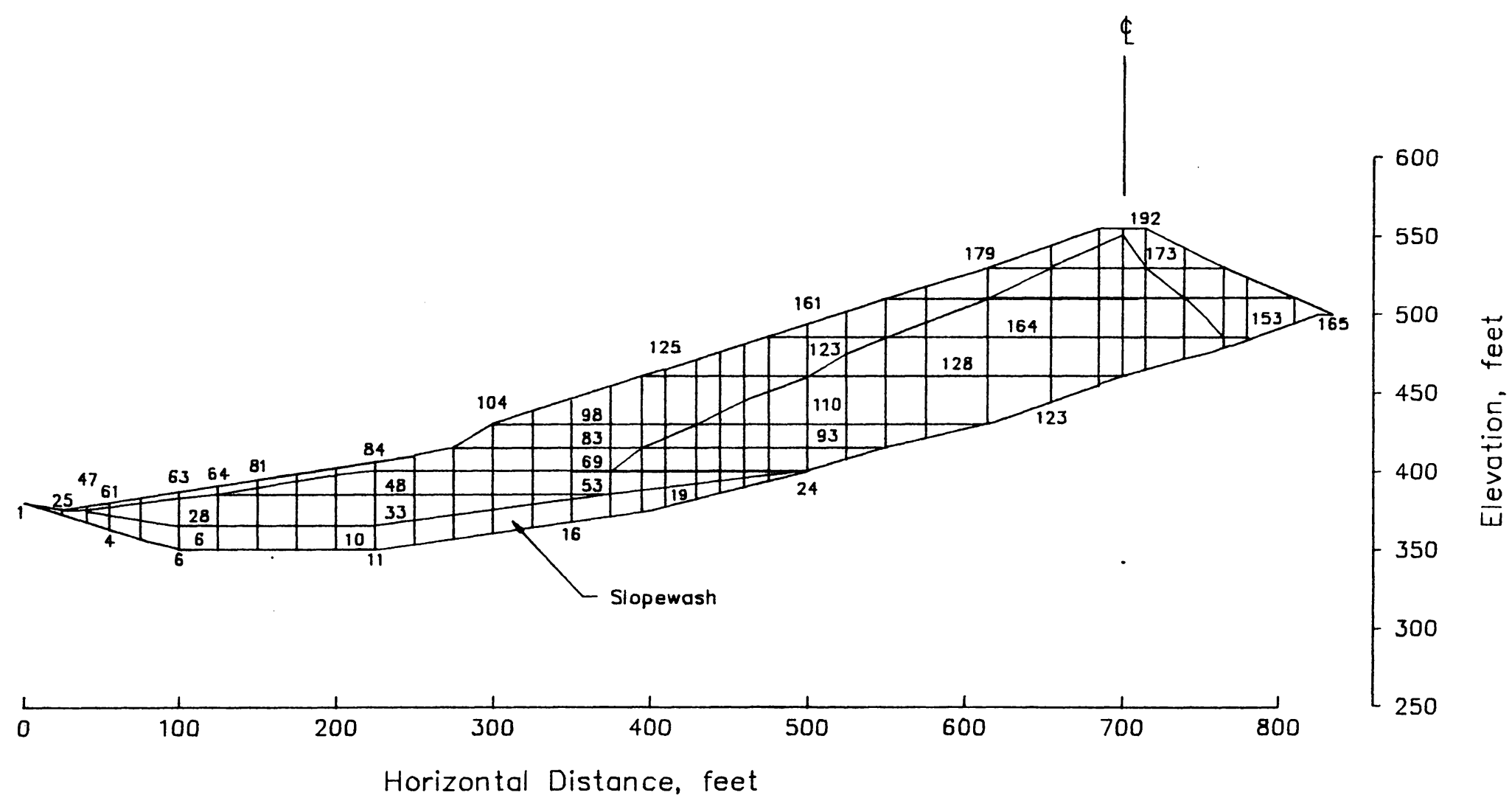

Figure 6-1 Finite Element Mesh at Station 135+00 
full and the reservoir drawn down conditions. The dry slopewash parameters, shown in Table 6-1, and total unit weights for all materials were used to analyze the end of construction condition. The soaked slopewash parameters were used for the reservoir full and the reservoir drawn down conditions. Bouyant unit weights were used for all materials in the reservoir full condition, while only the slopewash had bouyant unit weight'in the reservoir down condition.

In each of the analyses, construction of the embankment was simulated using nine layers using the plane strain finite element computer program FEADAM, developed by Duncan et al. (1984), running on an IBM-PC XT. The use of this type of analysis to establish stresses for the end of construction condition is a faithful simulation of the actual events involved in construction of the embankment. However, using "build-up" analyses to establish stresses for the reservoir full and the reservoir empty conditions does not model the actual events (embankment construction, followed by reservoir filling and emptying) that are involved in establishing these conditions. Previous studies (Duncan, personal communication) have shown, however, that these "build-up" analyses lead to accurate values of the stresses in the embankment. Although these analyses cannot be used to determine displacements because 
they do not follow the actual loading sequence, they do satisfy equilibrium for the final condition, and therefore provide a reasonable means of evaluating stress conditions. This method of analysis has been used for many dams to establish long-term static stresses for use in seismic safety evaluations.

\section{Calculated Stresses on the 1981 slide Plane}

Using the calculated stresses from the finite element analyses, the shear stresses acting on the 1981 slide plane were computed for three conditions: 1) the end of construction, 2) the reservoir full and 3 ) the reservoir empty with three different distributions of pore pressure in the slopewash. The magnitude of the shear and normal stresses on the 1981 slide plane were determined using Mohr's circles to resolve the stresses to the slide plane. In places where the slide plane did not pass through the center of an element, the stresses on the slide plane were interpolated between those in the elements above and below the slide plane.

The shear and normal stresses in the slopewash at the end of construction were computed using the parameters determined for the dry slopewash and total unit weights for all materials. As shown in Figure 6-2, the calculated shear and normal stresses increase gradually with distance 

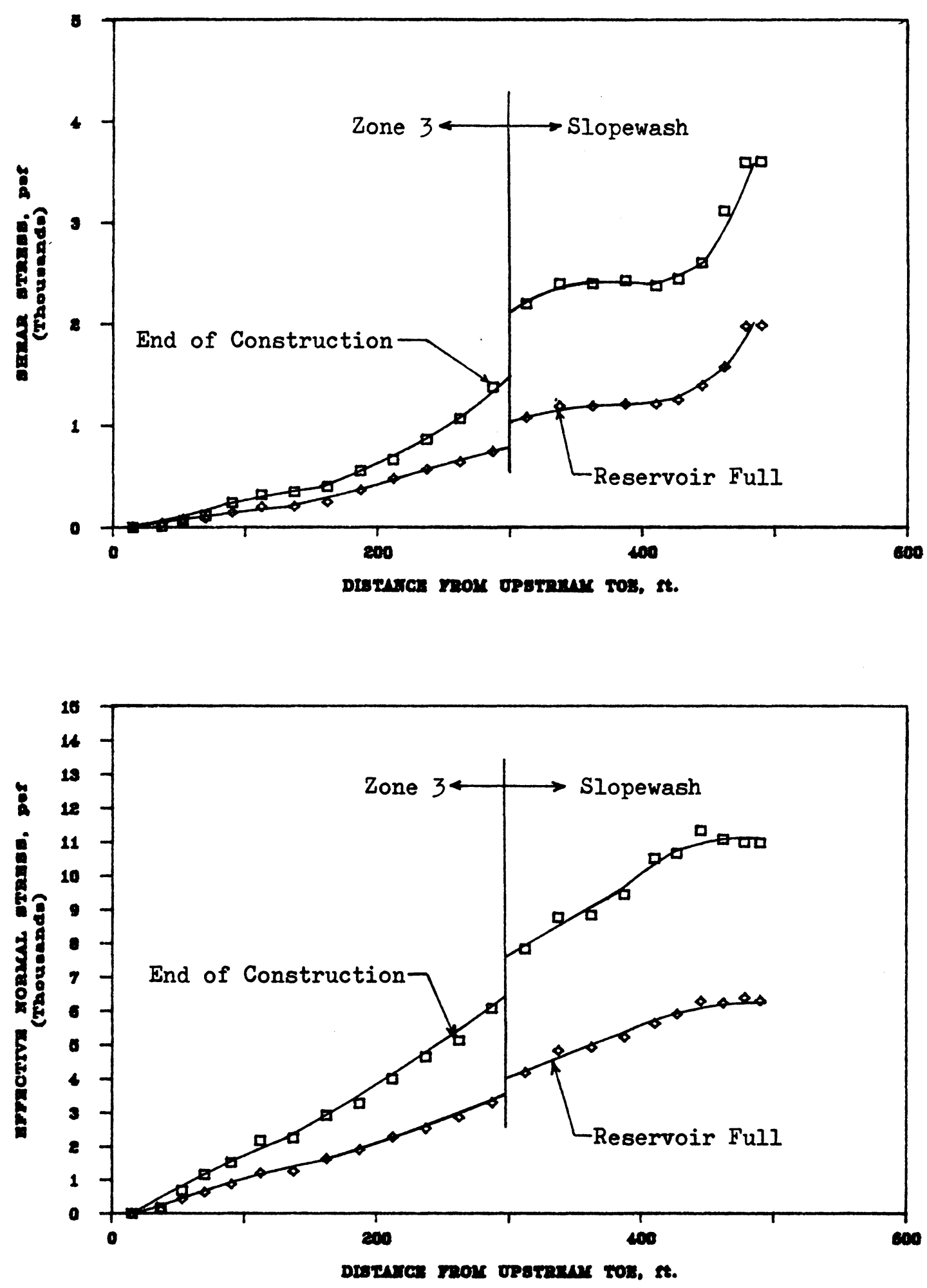

Figure 6-2 Calculated Shear and Normal Stresses at End of Construction and with Reservoir Full 
from the upstream toe to the point where the shear plane crossed into the slopewash material. The calculated shear stresses increase sharply at the boundary between the slopewash and the $\mathrm{Z}$ one 3 material, and increase with distance downstream, reaching their maximum value at the downstream end of the slopewash layer.

The shear stresses on the 1981 slide plane for the reservoir full condition were calculated using the drained upstream slopewash parameters and bouyant unit weights for all materials in the zones beneath the phreatic surface. As shown in Figure 6-2, the calculated shear and normal stresses for the reservoir full condition show a pattern similar to those for the end of construction shear stresses, but are about half as large.

The seepage analyses discussed in Chapter Four showed that fairly large excess pore pressures existed in the slopewash during drawdown, due to time lag in their dissipation. Two techniques were used to represent the pore pressures in the analyses of the reservoir down condition. The first technique involved applying nodal point forces along the top of the slopewash to represent the effects of the pore pressure in reducing the effective normal stresses. The second technique used reduced unit weights in the slopewash and the overlying zone 3 materials to model the reduction in effective normal stress caused by 
the pore pressures. As would be expected, both procedures gave essentially identical answers, and both were the same as the effective normal stresses determined by subtracting the pore pressures from the total normal stresses calculated in the finite element analyses.

As shown in Figure 6-3, using vertical nodal point loads to represent excess pore pressures in the slopewash had a minimal effect on the calculated values of shear stress. Based on the results, it was concluded that it would be appropriate to use the same shear stress distribution for any of the three pore pressure distributions to be considered (high, medium, or low). The effective normal stresses were affected, however, decreasing with increasing pore pressure, the decrease in effective normal stress being equal to the increase in pore pressure, as shown in Figure 6-3.

The shear and normal stresses calculated for the reservoir down condition were very similar to those calculated at the end of construction, as shown in Figure $6-4$.

\section{Stress Path for Laboratory Direct Shear Specimens}

The shear and normal stresses shown in Figures 6-2 and 6-3 were used to determine the stress paths to which laboratory direct shear test specimens would be subjected 

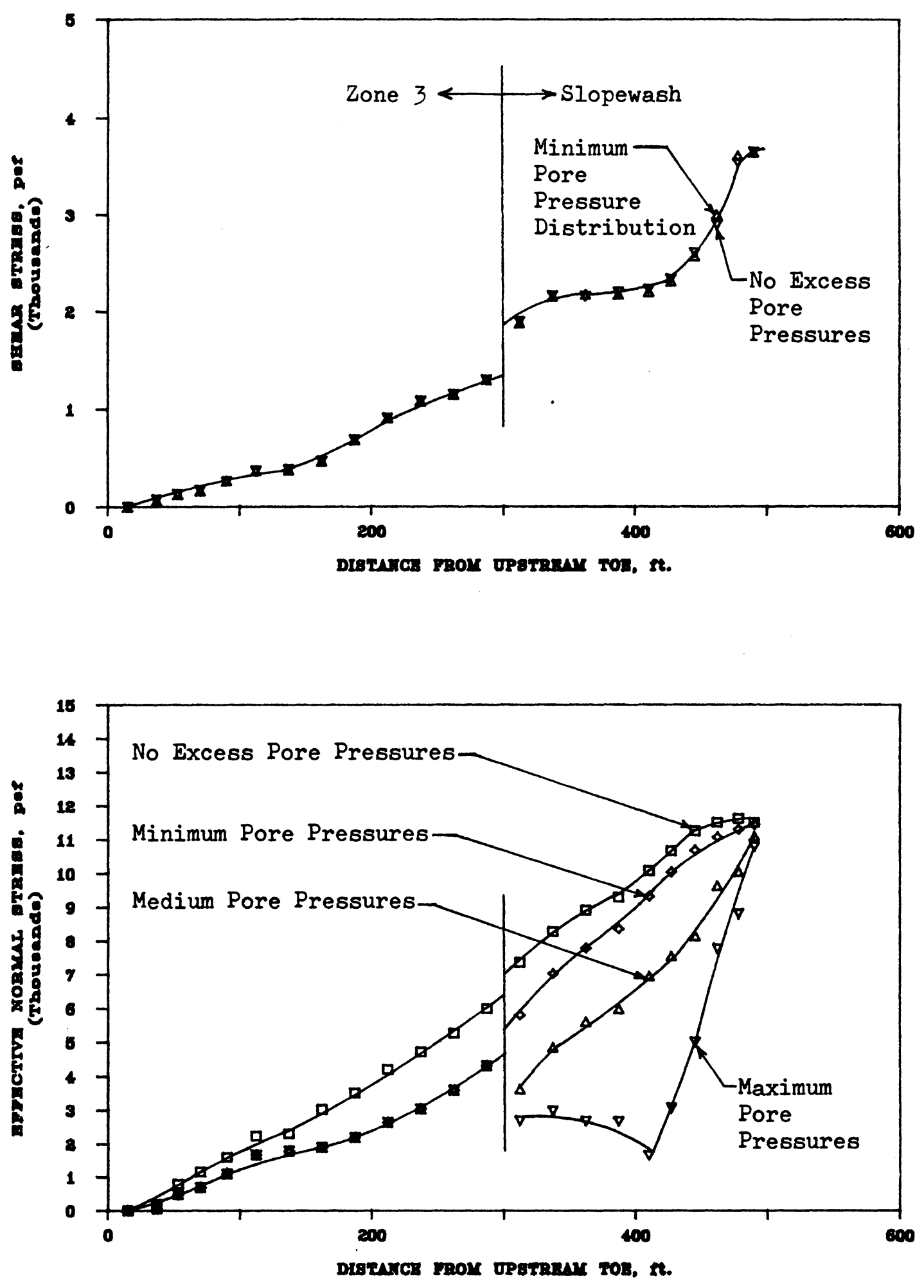

Figure 6-3 Effect of Pore Pressures on the Shear and Normal Stresses for the Reservoir Down Condition 

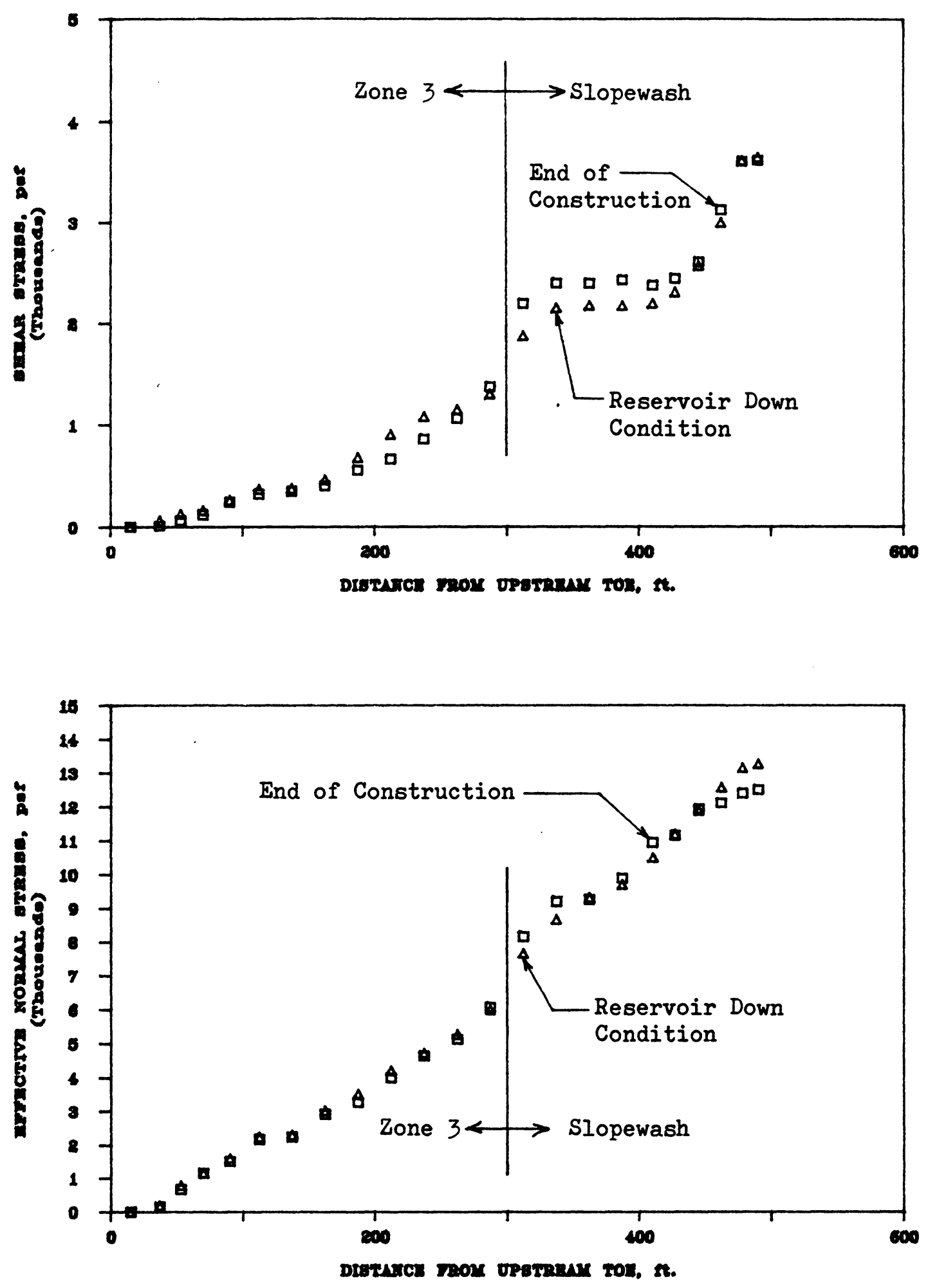

Figure 6-4 Shear and Normal Stresses for the End of Construction and Reservoir Down Conditions 
to simulate the events preceding the 1981 failure.

As shown in Figure 6-5, the slopewash was divided into two zones, A and $B$, and stress paths for each zone were determined. The shear and effective normal stresses in zones $A$ and $B$ for each condition (end of construction, reservoir full and reservoir down) are plotted on Mohr's diagrams in Figures 6-6 and 6-7 together with the direct shear failure envelopes. Three points corresponding to the reservoir down condition are plotted at different values of effective normal stress corresponding to the three pore pressure distributions (minimum, medium and maximum) discussed previously. As shown in Figure 6-6, most of the stresses in zone $A$ are at or below the residual condition. As a result, the shear and normal stresses in zone $B$, which lie between the residual strength and peak fully softened strength envelopes, were used in the direct shear tests.

As described in the next chapter, laboratory direct shear specimens were subjected to the zone B stress path shown in Figure 6-7 to simulate these conditions in the field: 1) end of construction, 2) reservoir full and 3) reservoir down with the medium pore pressures. After the third increment, the stresses were cycled back and forth between the reservoir full and reservoir down conditions to simulate annual reservoir cycles. 

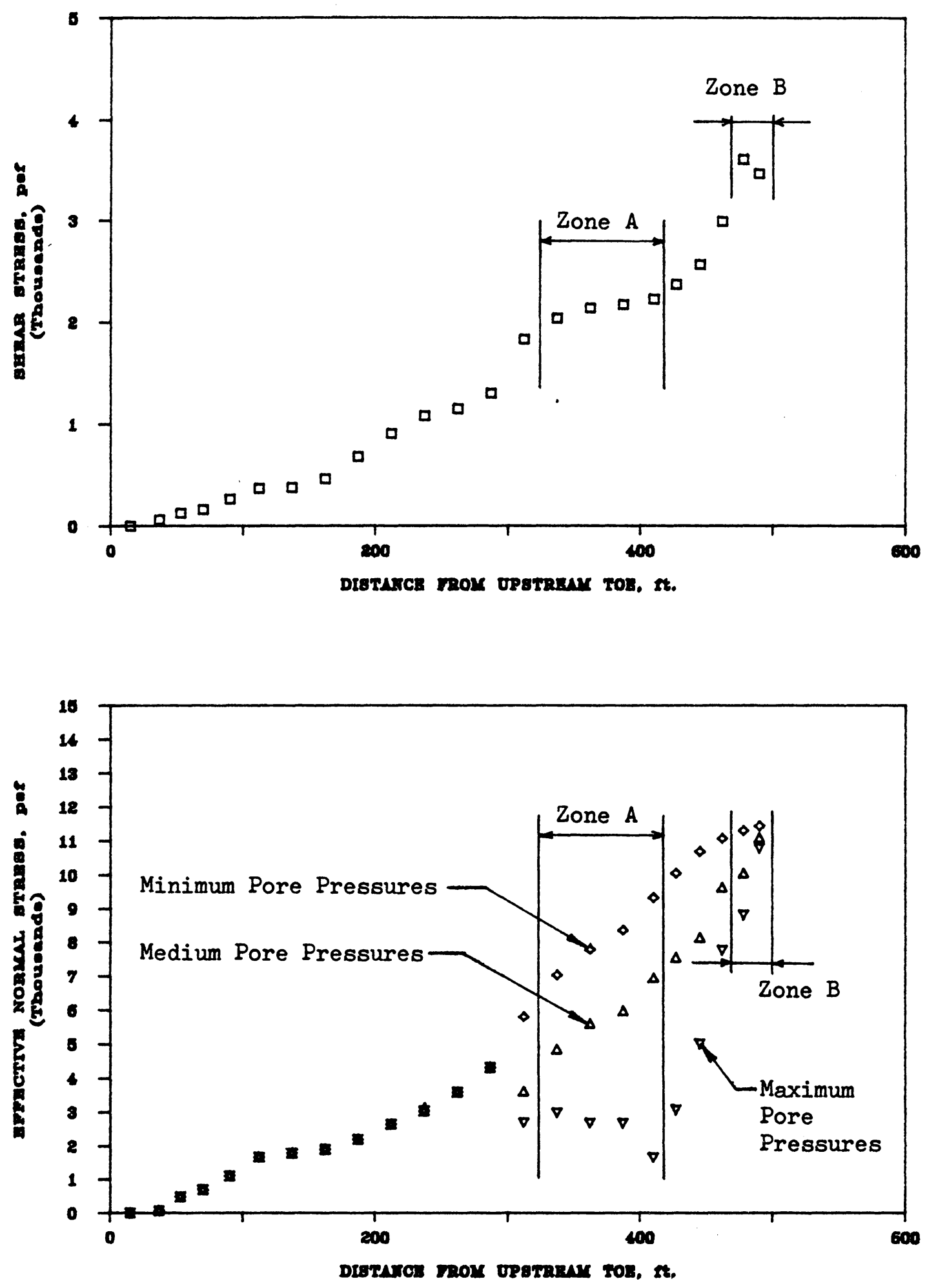

Figure 6-5 Reservoir Down Stress Conditions for Use in the Cyclic Direct Bhear Tests 


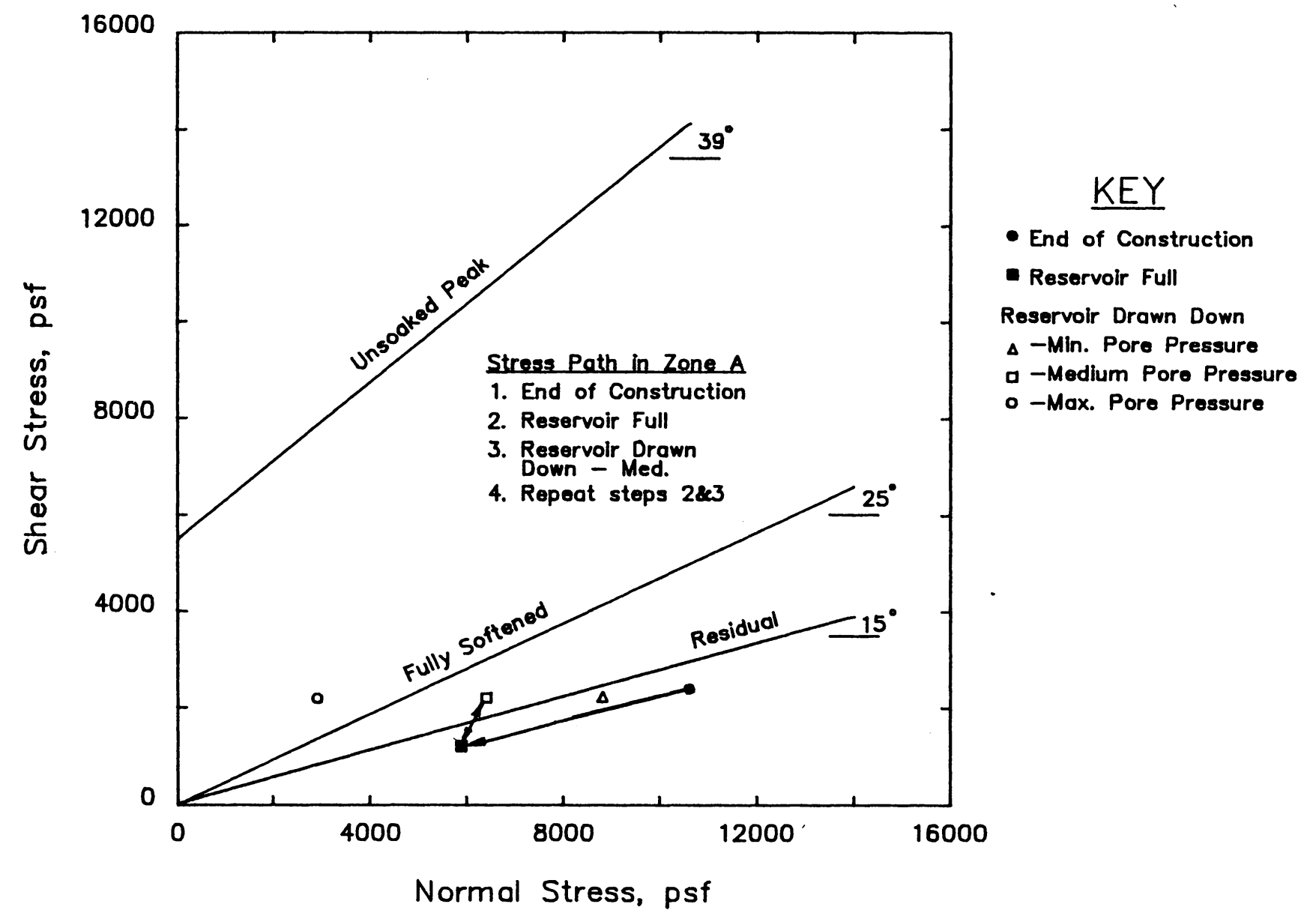

Figure 6-6 Stress Path in Zone A for Cyclic Direct Shear Tests 


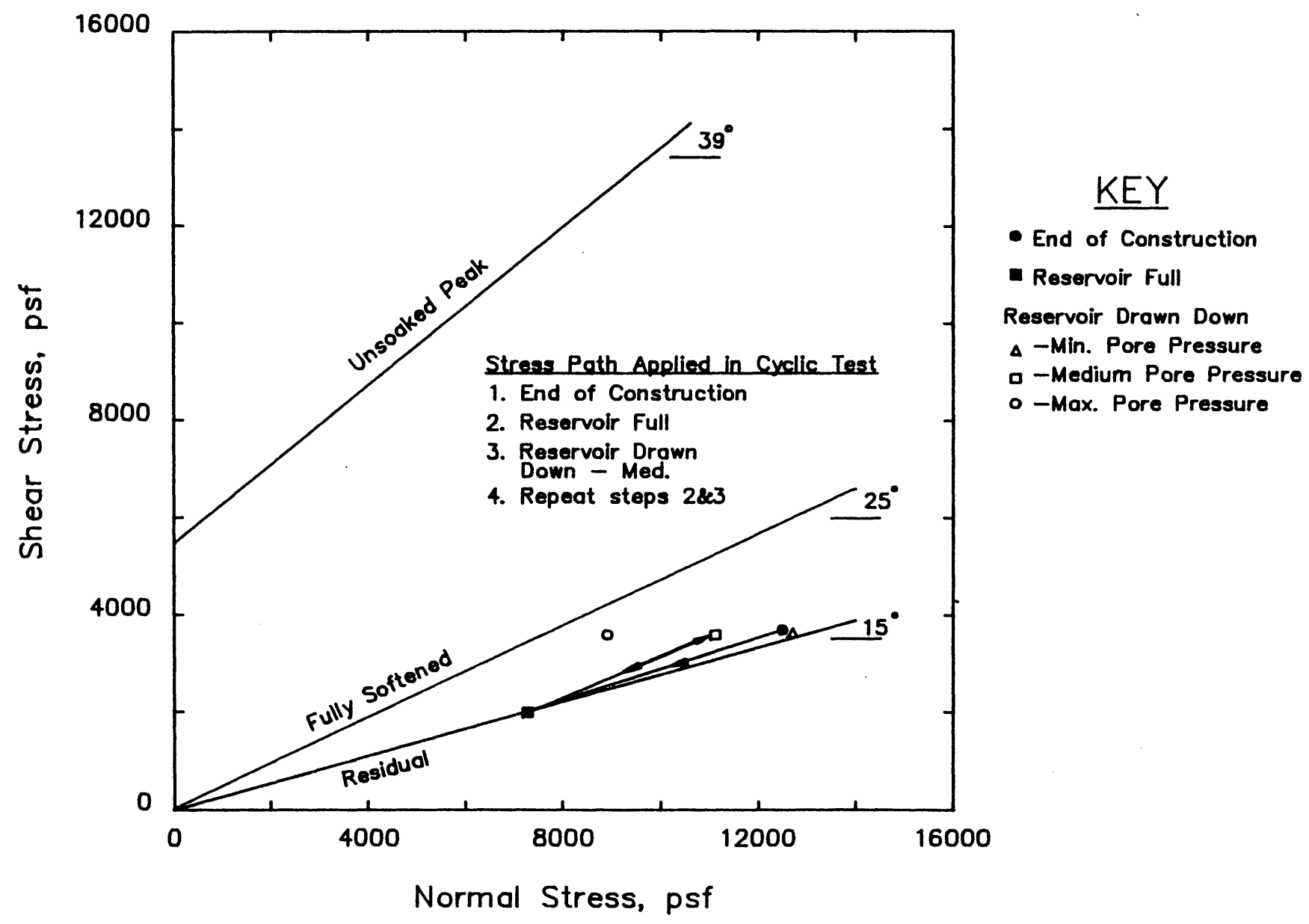

Figure 6-7 Stress Path in Zone B for Cyclic Direct Shear Tests 


\section{Summary}

The stress paths to be used in laboratory direct shear tests were determined by means of finite element analyses of the stresses in San Luis Dam and its foundation. The stress conditions are shown in Figure 6-7. 


\section{CHAPTER SEVEN - Strength Loss Due to Cyclic Loading}

\section{Introduction}

The drained direct shear tests described in this chapter were conducted to investigate the effects of cyclic shear stresses on the shear strength of the slopewash material.

This was accomplished by performing cyclic direct shear tests in which the slopewash was subjected to shear and normal stresses that simulated the rise and fall of San Luis reservoir. The stress path employed in these tests determined using the results of the finite element analyses of San Luis Dam described in Chapter Six is shown in Figure $6-7$.

\section{Cyclic Direct Shear Test Procedure}

Two drained cyclic direct shear tests were conducted on undisturbed test specimens. The first was conducted on an initially dry specimen of the slopewash from downstream, and the second was performed on an initially wet specimen of the slopewash from upstream. Each specimen was four inches square and approximately 0.8 inches thick. The test specimens were prepared using the procedures described in Chapter Three.

The first specimen was subjected to stress states that 
represented the end of construction condition, the reservoir full condition and the 1981 drawdown condition. Table 7-1 gives the shear and normal stresses that were used to represent each condition. These were determined from the finite element analyses using the "medium" or most probable pore pressures during drawdown. The second test was a continuation of the first, used to reach larger shear displacements.

\section{First Cyclic Direct Shear Test}

The first cyclic direct shear test was conducted using an undisturbed downstream slopewash specimen from block sample 36F-1103. The test specimen was consolidated to an effective normal stress of 12,440 psf and was then sheared until a shear stress of 3610 psf was reached, as shown in Figure 7-1. This represented the stresses on an average element of the slopewash at the end of construction.

After the end of construction stresses had been applied, the test was stopped and the sample was soaked for one day to simulate the filling of the reservoir. Immediately after adding water to the shear box the sample was seen to compress and the shear stress dropped from 3610 to 2100 psf with no change in shear displacement. After reducing the effective normal stress to 7240 psf to simulate the reservoir full condition, additional shear 
TABLE 7-1 - Stress Conditions Used in the Cyclic Direct Shear Tests

Condition

End of Construction

Reservoir Full

1981 Drawdown Condition Medium Pore Pressures
Shear Stress (psf)

3610

1980

3600

Effective Normal Stress (psf)

12,440

7240

11,140 

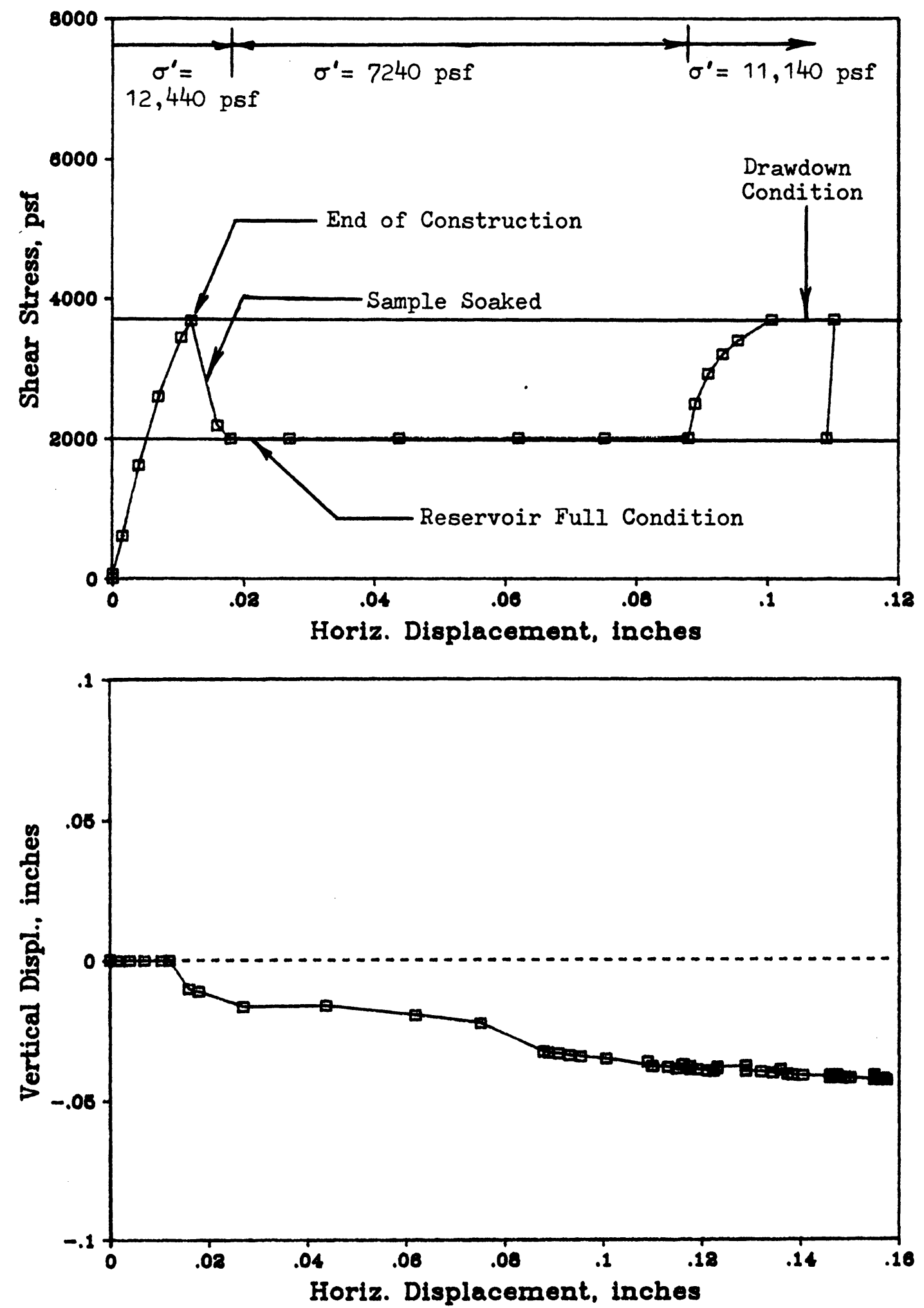

Figure 7-1 End of Construction and Reservoir Full Conditions in First Cyclic Direct Shear Test 
displacement was required to maintain a shear stress near the desired 1980 psf.

The displacement rate was varied over a period of three hours, until a rate of 0.0000384 inches per minute was found to maintain the desired shear stress of 1980 psf on the specimen. As shown in Figure 7-1, the displacements increased to about 0.09 inches during the 24 hour period while the reservoir full stress condition was maintained.

After the reservoir full stress condition had been maintained for 24 hours, the normal stress was increased to 11,140 psf and the shear stress was increased to 3600 psf to represent the 1981 drawdown condition. The horizontal displacement rate was varied until a rate of 0.000192 inches per minute was found to maintain the desired shear stress for the drawdown condition, 3600 psf. During the three hours that the drawdown stress condition was applied, the slopewash had to be sheared continuously to maintain the shear stress.

To simulate rise and fall of the reservoir, the slopewash specimen was subjected to repeated cycles of stress, alternating between the reservoir full and the drawdown stress conditions. Figure 7-2 shows the displacements resulting from application of seven reservoir cycles. During each reservoir cycle the reservoir full condition was maintained for only an hour, since the 

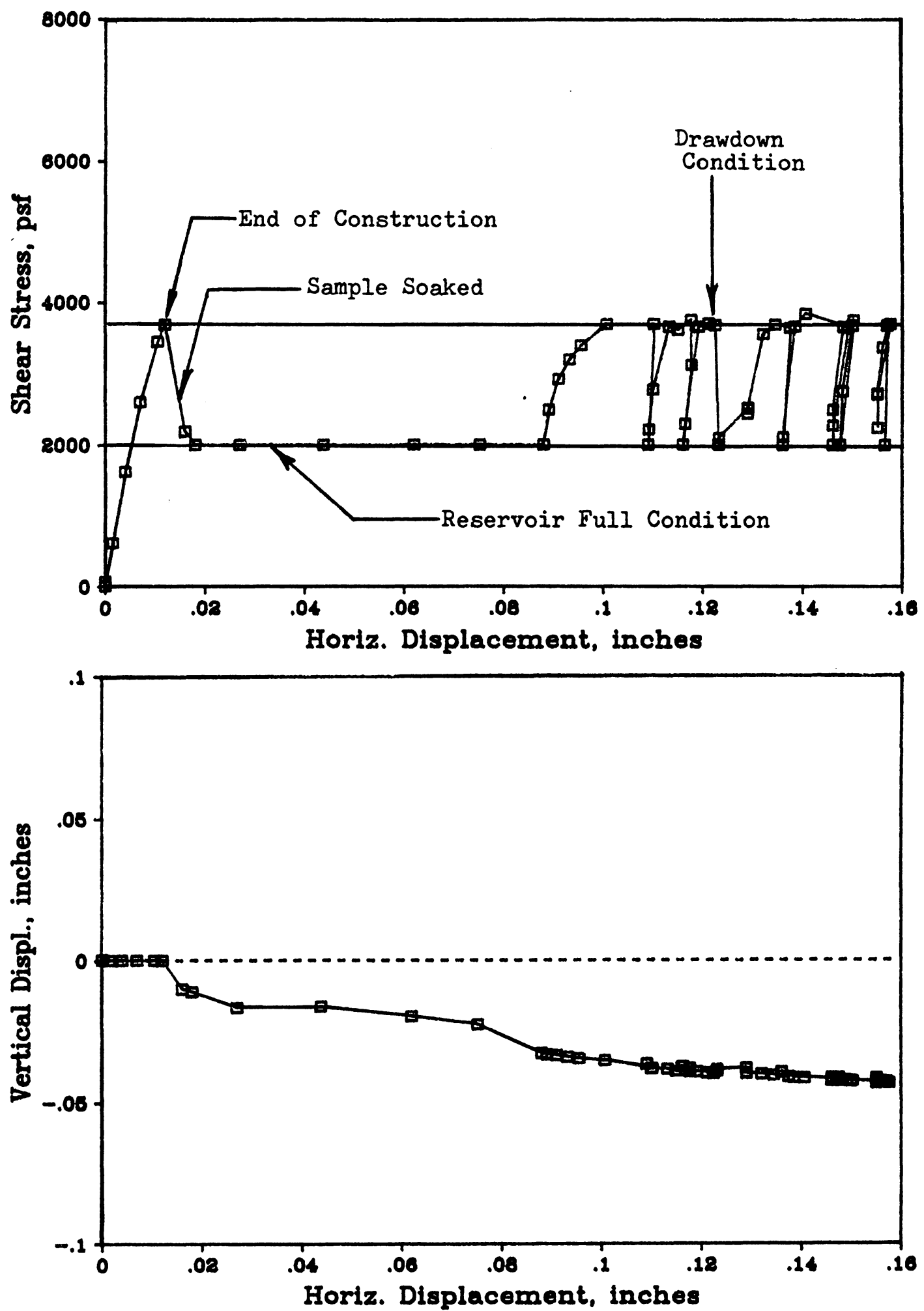

Figure 7-2 First Seven Reservoir Cycles in First Cyclic Direct Shear Test 
specimen was able to maintain this value of shear stress with very little displacement.

It can be seen from Table 7-2 that the rate of horizontal displacement decreased from $0.000109 \mathrm{in} / \mathrm{min}$ during the first cycle to $0.000006 \mathrm{in} / \mathrm{min}$ during the seventh cycle. Upon review of the data obtained during the first seven loading cycles, it appeared likely that some interference was developing between the upper and lower halves of the shear box. Similar occurrences had been noted in earlier phases of the testing and were described in Chapter 3.

To eliminate this interference, the top of the shear box was raised 0.06 inches prior to the eighth load cycle. As expected, the shear deformation rate increased, reaching $0.000041 \mathrm{in} / \mathrm{min}$ during this cycle. As shown in Figure 7-3, the displacement during the eighth cycle greatly exceeded that during the seventh cycle. However, the shear displacement decreased to $0.000001 \mathrm{in} / \mathrm{min}$ during the ninth cycle, indicating the likelihood that interference had again developed.

On the basis of this experience it was concluded that rock fragments were causing some additional apparent shearing resistance which was obscuring the behavior of the soil. To remedy the situation the top of the shear box was raised approximately 0.03 inches before the start of each 
TABLE 7-2 - Summary of Cyclic Direct Shear Test \#l on Downstream Slopewash

\begin{tabular}{|c|c|c|c|c|c|}
\hline \multicolumn{2}{|c|}{$\begin{array}{l}\text { Reservoir } \\
\text { Cycle }\end{array}$} & \multirow{2}{*}{$\begin{array}{l}\text { Length } \\
\text { of Cycle } \\
\text { (min) } \\
1405\end{array}$} & \multirow{2}{*}{$\begin{array}{l}\text { Horizontal } \\
\text { Displacement } \\
\text { Per Cycle } \\
\text { (inches) } \\
0.072\end{array}$} & \multirow{2}{*}{$\begin{array}{c}\text { Average } \\
\text { Horizontal } \\
\text { Displacement } \\
\text { Rate } \\
\text { (in/min) } \\
0.000051\end{array}$} & \multirow{2}{*}{ 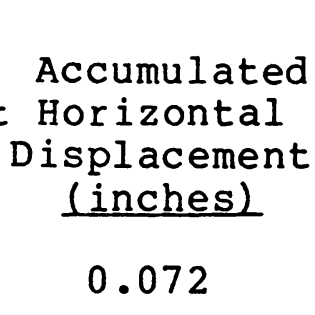 } \\
\hline * & 0 & & & & \\
\hline & 1 & 202 & 0.022 & 0.000109 & 0.094 \\
\hline & 2 & 322 & 0.007 & 0.000022 & 0.101 \\
\hline & 3 & 916 & 0.013 & 0.000014 & 0.114 \\
\hline & 4 & 510 & 0.007 & 0.000014 & 0.121 \\
\hline & 5 & 967 & 0.008 & 0.000008 & 0.129 \\
\hline & 6 & 516 & 0.005 & 0.000010 & 0.134 \\
\hline & 7 & 1057 & 0.006 & 0.000006 & 0.140 \\
\hline * * & 8 & 1547 & 0.064 & 0.000041 & 0.204 \\
\hline & 9 & 1313 & 0.001 & 0.000001 & 0.205 \\
\hline * * & 10 & 2010 & 0.016 & 0.000008 & 0.221 \\
\hline ** & 11 & 1165 & 0.025 & 0.000021 & 0.246 \\
\hline ** & 12 & 1390 & 0.049 & 0.000035 & 0.295 \\
\hline ** & 13 & 1131 & 0.056 & 0.000050 & 0.351 \\
\hline * * & 14 & 1576 & 0.071 & 0.000045 & 0.422 \\
\hline * * & 15 & 1493 & 0.154 & 0.000098 & 0.576 \\
\hline * * & 16 & 1097 & 0.307 & 0.000280 & 0.883 \\
\hline * * & 17 & 1465 & 0.492 & 0.000336 & 1.375 \\
\hline ** & 18 & 1325 & 0.657 & 0.000496 & 2.032 \\
\hline
\end{tabular}

* Sample flooded to simulate reservoir filling. * Raised top of shear box before start of cycle. Water contents: Initial $=10 \%$ and Final $=18 \%$. 


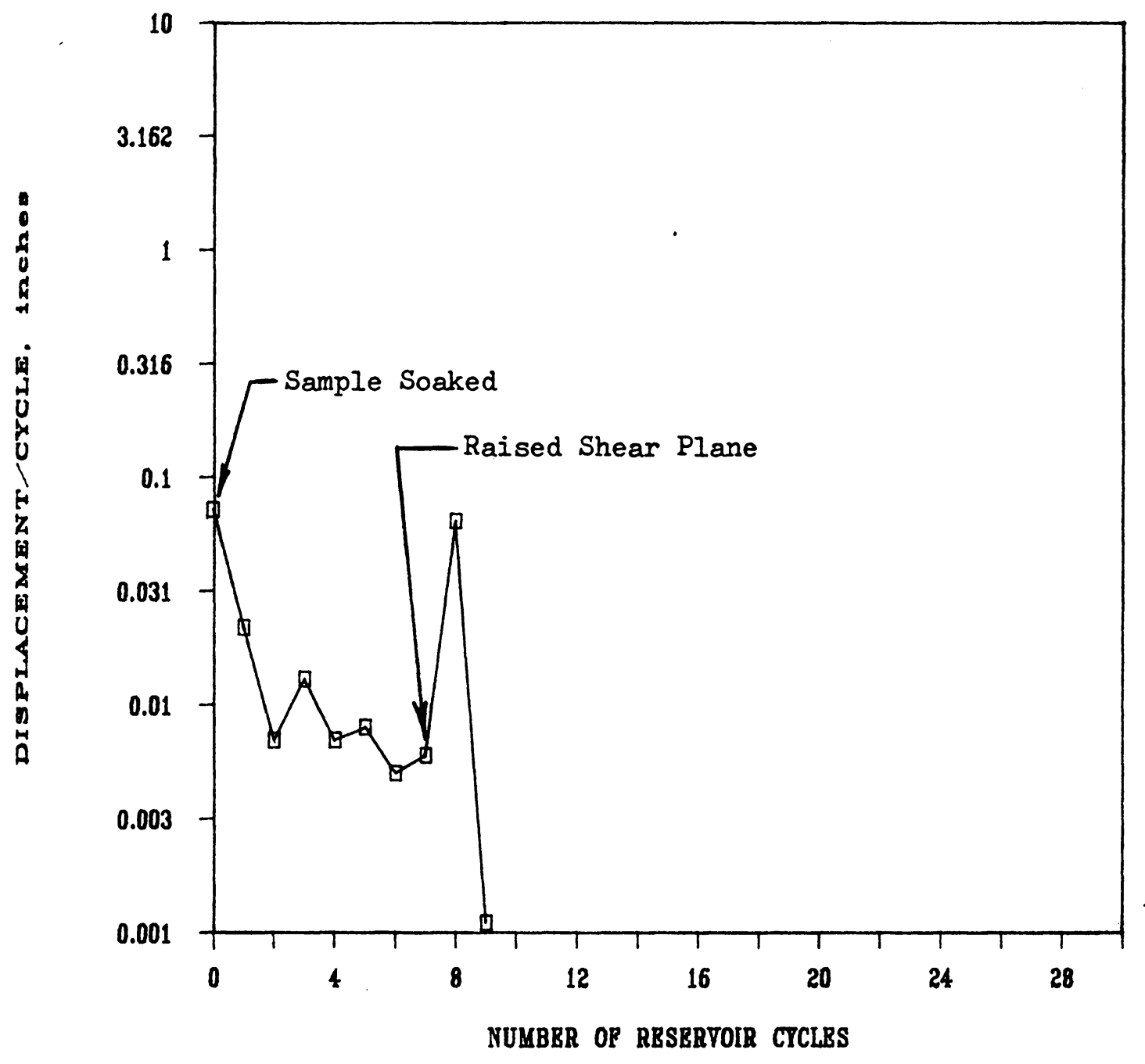

Figure 7-3 Horizontal Displacement During First Nine Reservoir Cycles in First Cyclic Direct Shear Test 
of the next nine cycles. The displacements measured were found to increase with each cycle when this was done. As shown in Figure 7-4, the horizontal displacement per cycle increased exponentially with the number of cycles. During each of the last nine cycles the drawdown stress condition was applied for approximately 21 hours.

A total of 18 reservoir cycles were applied before the majority of the test specimen was'lost through the gap between the top and bottom of the shear box and the test could not be continued. From Figure 7-5 it can be seen that the horizontal displacement accumulated throughout the test increased steadily with the number of stress cycles applied. These results suggest that the slopewash in the foundation of San Luis Dam was continually deforming during the annual reservoir cycles, even though the shear stresses were smaller than the fully softened shear strength and the factor of safety calculated using conventional procedures was greater than unity.

Slope stability analyses discussed in Chapter Five indicate the shear strength of the slopewash was close to residual at the time of the 1981 slide. In laboratory direct shear tests a residual strength condition was reached after nine to ten inches of displacement had occurred. It is therefore of interest to estimate how many drawdown cycles in the field might have been required to 


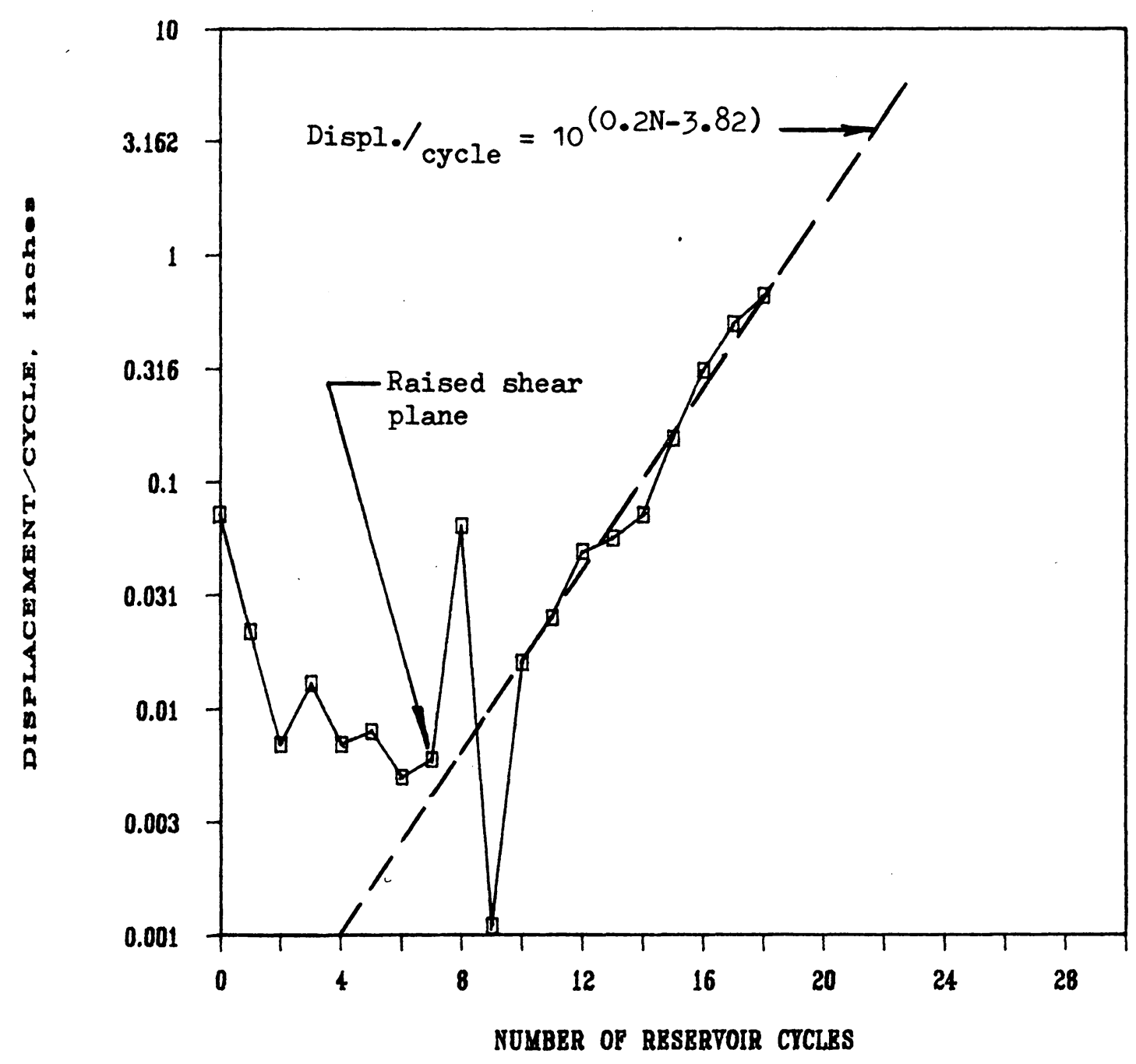

Figure 7-4 Horizontal Displacement per Reservoir Cycle in First Cyclic Direct Shear Test 


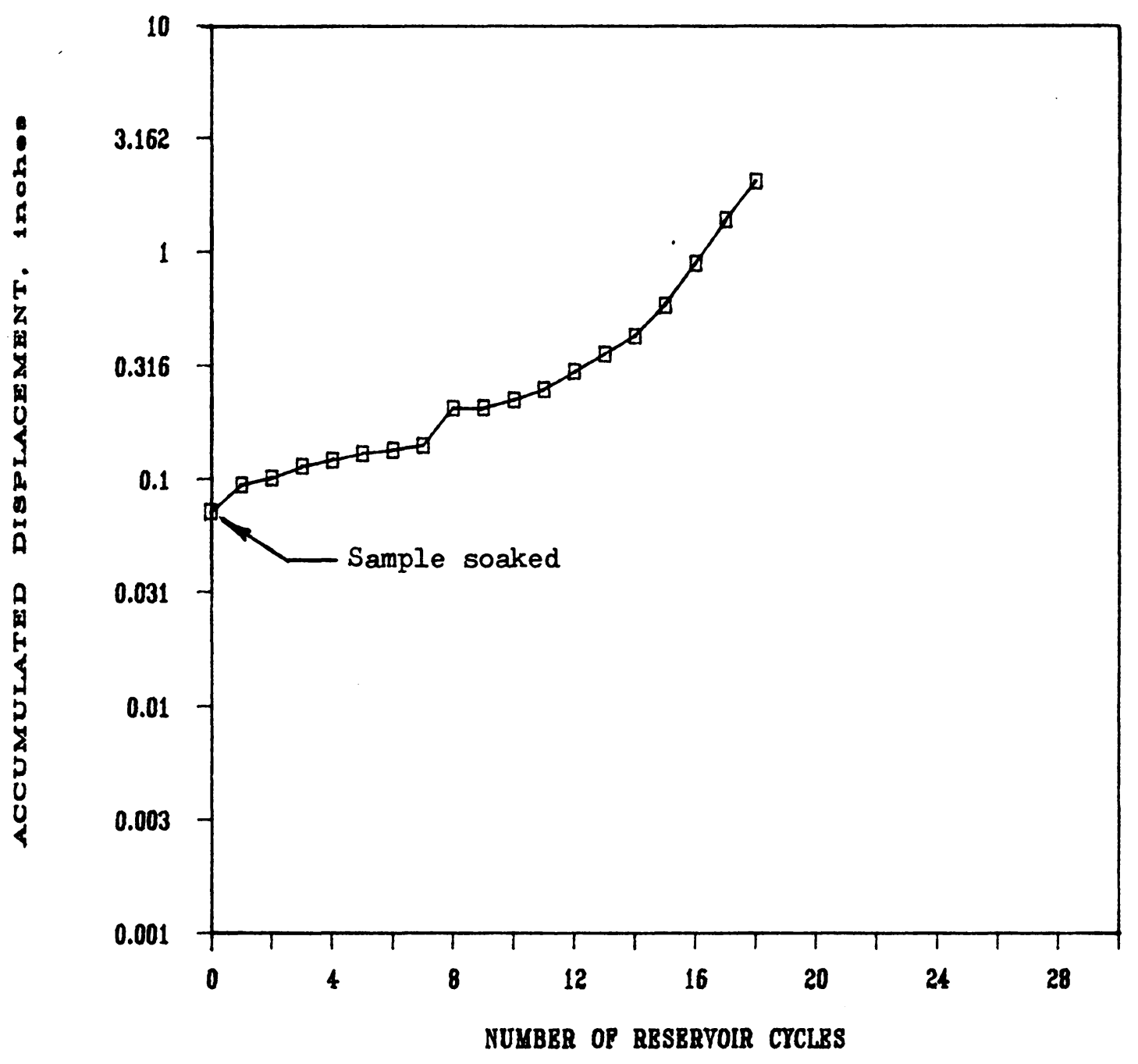

Figure 7-5 Total Displacement per Reservoir Cycle in First Cyclic Direct Shear Test 
accumulate eight to ten inches of displacement.

To estimate the required number of cycles, the total time the drawdown stresses were applied was plotted against the cumulative displacement, as shown in Figure 7-6. Each reservoir cycle lasted approximately 24 hours, with the drawdown condition being applied for 20 to 21 hours per cycle. From Figure 7-6, it appears that a displacement of ten inches would occur if the drawdown condition was applied for a total of approximately 500 hours or 20 days. It seems possible that the slopewash was subjected to a total of 20 to 30 days of severe drawdown during the rapid drawdowns of 1976, 1977 and 1981, as may be seen in Figure $4-3$.

This approximate analysis thus indicated that the 1981 slide was the end result of cyclic loading during many years of drawdown in the reservoir, most notably the largest and most rapid cycles which occurred in 1976, 1977, and 1981. The results help to explain why the slide occurred in 1981, some 14 years after construction of the dam. It is interesting to note that the slide would probably have occurred even later if the 1981 drawdown had been less severe.

Thus it appears the shear strength of the slopewash was reduced from the fully softened condition to a value near residual by the cyclic variations of the shear and 


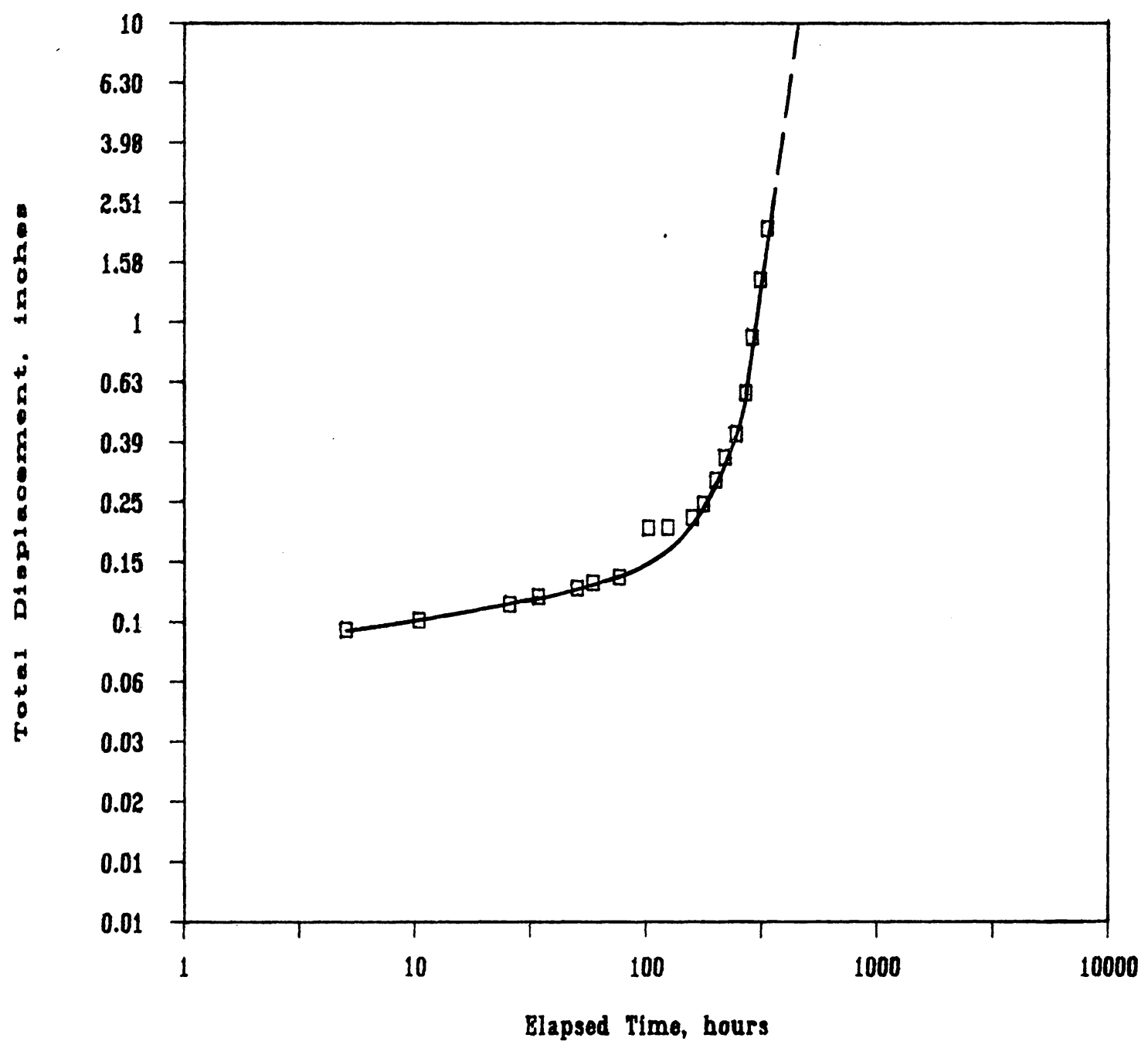

Figure 7-6 Total Displacement During the Drawdown Condition in the First Cyclic Direct Shear Test 
normal stresses in the foundation during the cycles of reservoir filling and emptying that preceded the 1981 slide. In addition, it appears the extent and duration of each drawdown condition influenced the time required for reduction of the strength to its residual value. The following paragraphs describe a second cyclic direct shear test which was conducted to examine further the strength loss resulting from cyclic loading.

\section{Second Cyclic Direct Shear Test}

A second cyclic direct shear test was conducted on an undisturbed upstream slopewash sample to continue applying stress cycles where the first test had been stopped. The upstream sample was sheared 1.9 inches, approximately the final displacement of the first test, and was then subjected to eight stress cycles, as shown in Figure 7-7.

As shown in Table 7-3, the displacement during the second reservoir cycle was quite small compared to that measured during the first cycle. The top of the shear box was raised 0.03 inches before the third cycle, and, as can be seen in Figure 7-8, the displacement per cycle increased considerably. This reconfirmed the conclusion that some additional shearing resistance, probably due to small rock fragments being caught between the top and bottom of the shear box, was reducing the horizontal displacement rate. 

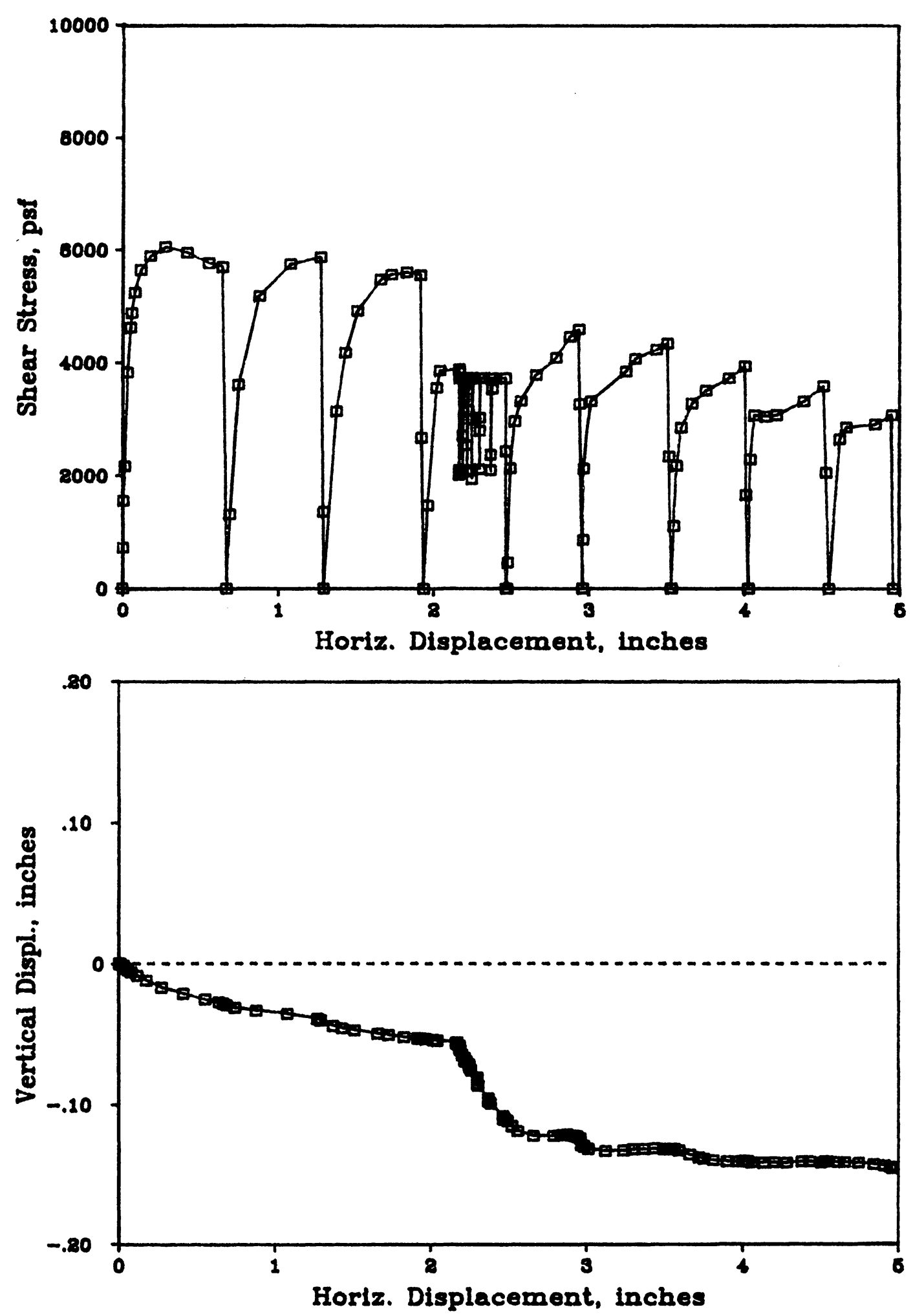

Figure 7-7 Second Cyclic Direct Shear Test 
TABLE 7-3 - Summary of Cyclic Direct Shear Test \#2 on Upstream Slopewash

$$
\text { Average }
$$

Horzontal

$\begin{array}{ccccc}\begin{array}{c}\text { Reservoir* } \\ \text { Cycle }\end{array} & \begin{array}{c}\text { Length } \\ \text { Of Cycle } \\ \text { (min) }\end{array} & \begin{array}{c}\text { Displacement } \\ \text { Per Cycle } \\ \text { (inches) }\end{array} & \begin{array}{c}\text { Displacement } \\ \text { Rate } \\ \text { (in/min) }\end{array} & \begin{array}{c}\text { Accumulated } \\ \text { Displacement } \\ \text { (inches) }\end{array} \\ * * * * 1 & 205 & 1.917 & 0.0094 & 1.917 \\ 2 & 795 & 0.239 & 0.00030 & 2.156 \\ * * * 3 & 1050 & 0.002 & 0.000002 & 2.158 \\ * * * 4 & 1390 & 0.021 & 0.000015 & 2.179 \\ * * * 5 & 1280 & 0.029 & 0.000023 & 2.208 \\ * * * 6 & 1775 & 0.031 & 0.000017 & 2.239 \\ * * * 7 & 1440 & 0.051 & 0.000035 & 2.290 \\ * * * 8 & 1500 & 0.071 & 0.000047 & 2.361 \\ & 1440 & 0.095 & 0.000066 & 2.456\end{array}$

* One cycle consists of reducing the stresses to the reservoir full condition and then increasing them to the drawdown condition.

* Displacement at which the first cyclic direct shear test was stopped.

*** Raised top of shear box.

Water contents: Initial $=188$ and $\mathrm{F}$ inal $=188$. 


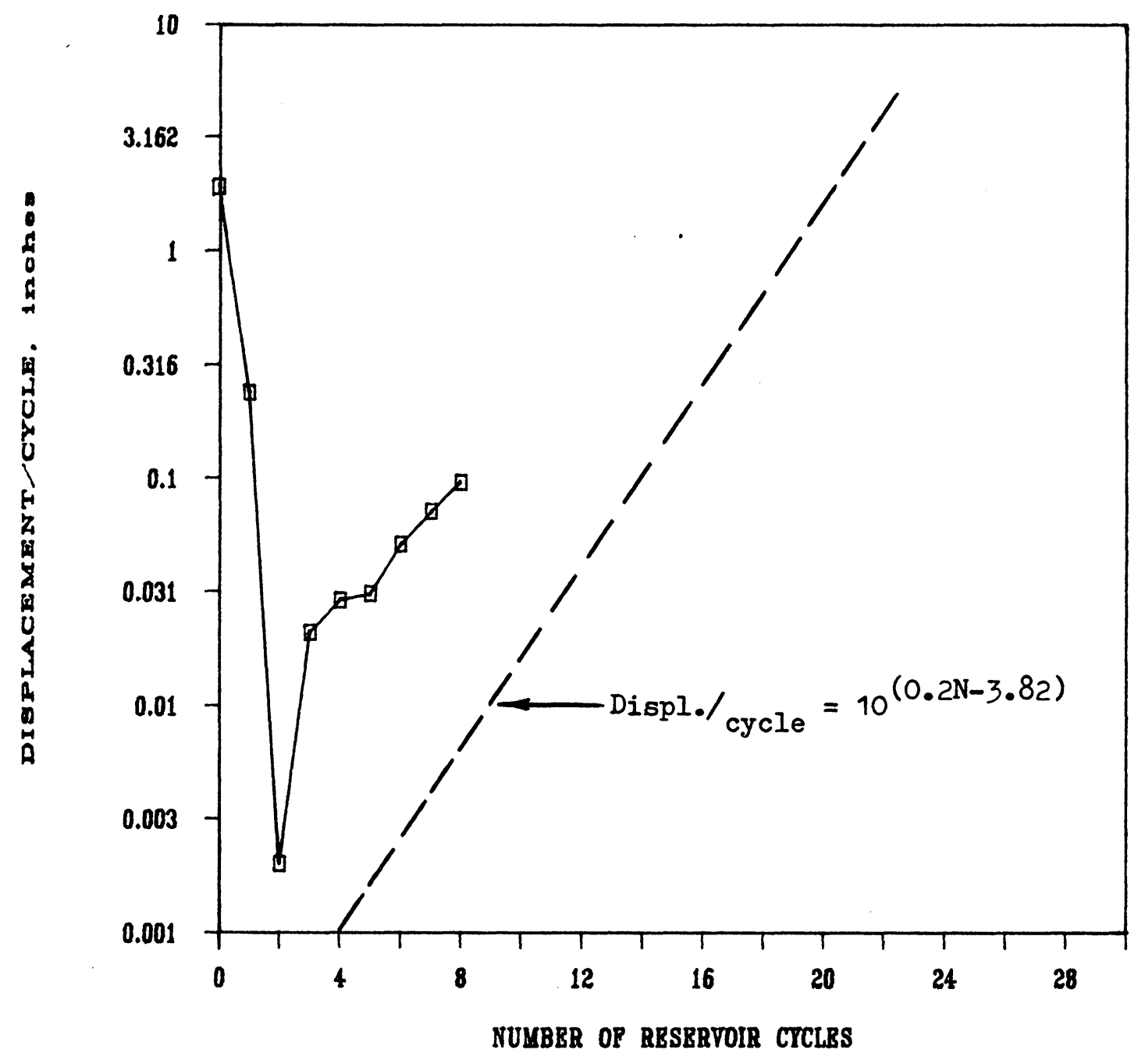

Figure 7-8 Horizontal Displacement per Reservoir Cycle in Second Cyclic Direct Shear Test 
The equation shown in Figure $7-4$, which relates horizontal displacement to the number of cycles, was used to construct the line shown in Figure 7-8. It can be seen that the slope of this line is nearly the same as the trend observed during the second test. In addition, the data in Figures 7-9 and 7-10 show that the displacements accumulated during the second test are similar to those observed in the first test. Initially, the curves in both figures are offset vertically by about 0.2 inches of displacement, which is due to raising the top of the shear box before the first reservoir cycle was applied in the second test. However, the curves have similar slopes which indicates the displacements per reservoir cycle and the time required for ten inches of displacement to occur were in good agreement.

From these results it appears that the slopewash probably underwent shear deformations during each significant reservoir drawdown cycle. To determine the effect of these deformations on the shear strength of the slopewash, the test specimen from the second test was sheared using the procedure described in Chapter Three after the eighth reservoir cycle had been applied.

As can be seen in Figure 7-7, the maximum shear stress measured during the first travel of the shear box was approximately 1300 psf lower than the fully softened peak 


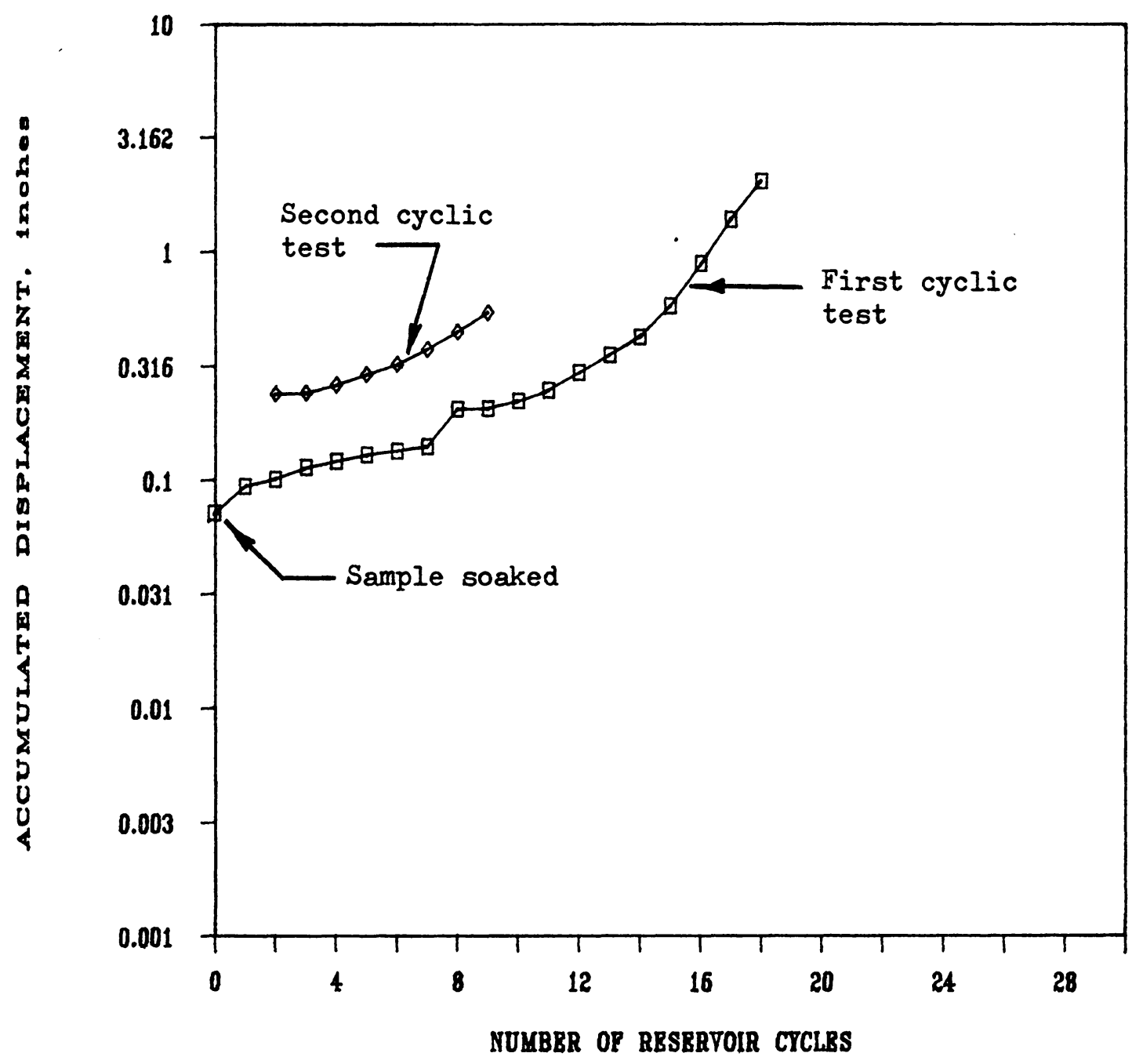

Figure 7-9 Total Displacement per Reservoir Cycle in Both Cyclic Direct Shear Tests 


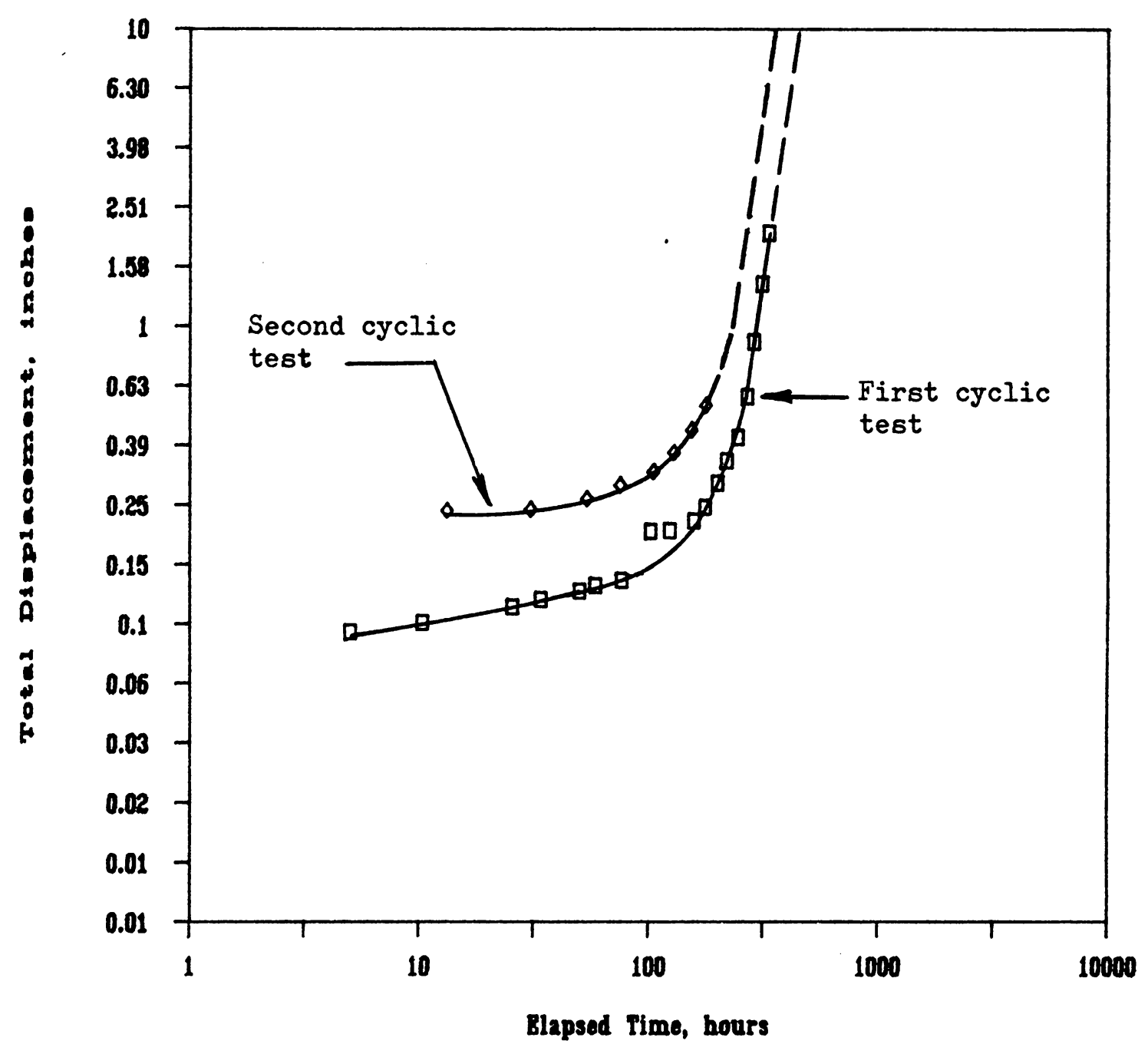

Figure 7-10 Total Displacement During the Drawdown Condition in Both Cyclic Direct Shear Tests 
shear stress. After 2.0 inches of displacement (four travels of the shear box) the measured shear stress had been reduced to the shear stress during the drawdown condition ( $3600 \mathrm{psf})$. This indicates that the specimen would undergo large shear displacements if it were subjected to the drawdown stress condition. As the displacements increased the shear strength of the specimen continued to decrease, until eventually a residual strength condition was obtained.

\section{Summary}

The results of the cyclic direct shear tests show that the slopewash deforms continuously when subjected to cycles of stress that simulate the filling and emptying of the reservoir. In the laboratory the cumulative deformations reached about two inches after eight cycles of loading, each of which was applied for about 24 hours.

Extrapolating these displacements to ten inches, it appears that the application of 20 to 30 days of severe drawdown conditions would produce a residual strength condition in the slopewash material. The large drawdowns in 1976, 1977 and 1981 appear to have caused enough shearing displacement to reduce the strength of the slopewash from its fully softened peak value to its residual value. 
Thus the accumulation of shear displacements under the cyclic loading imposed by the drawdown cycles appears to have been a key factor in the occurrence of the slide in San Luis Dam in September, 1981. 


\section{CHAPTER EIGHT- Stability and Performance of San Luis Dam After Construction of Stabilizing Berm}

\section{Introduction}

The 1981 slide in the upstream slope of San Luis Dam was repaired by reconstructing the crest and constructing a rockfill berm at the toe of the upstream slope between Stations $122+00$ and 139+00. Due to time and cost constraints, most of the material displaced by the slide was not removed during the repair. A cross-section of the repaired embankment at station $135+00$ is shown in Figure 8-1.

The reservoir was refilled in the spring of 1982 and did not undergo a significant drawdown until the summer of 1984; Figure 4-3 shows the history of reservoir operations. In 1984, following about 100 feet of drawdown at a rate of 1-1/3 feet per day, cracks approximately half an inch wide developed in the newly resurfaced crest road over a period of about 20 days. The cracks extended longitudinally, in a discontinuous pattern, between Stations $134+00$ and $136+00$.

The finite element and stability analyses described in this chapter were performed to evaluate the significance of the 1984 movements in San Luis Dam and to estimate the possible movements during future large drawdown cycles. slope stability analyses were also performed. 


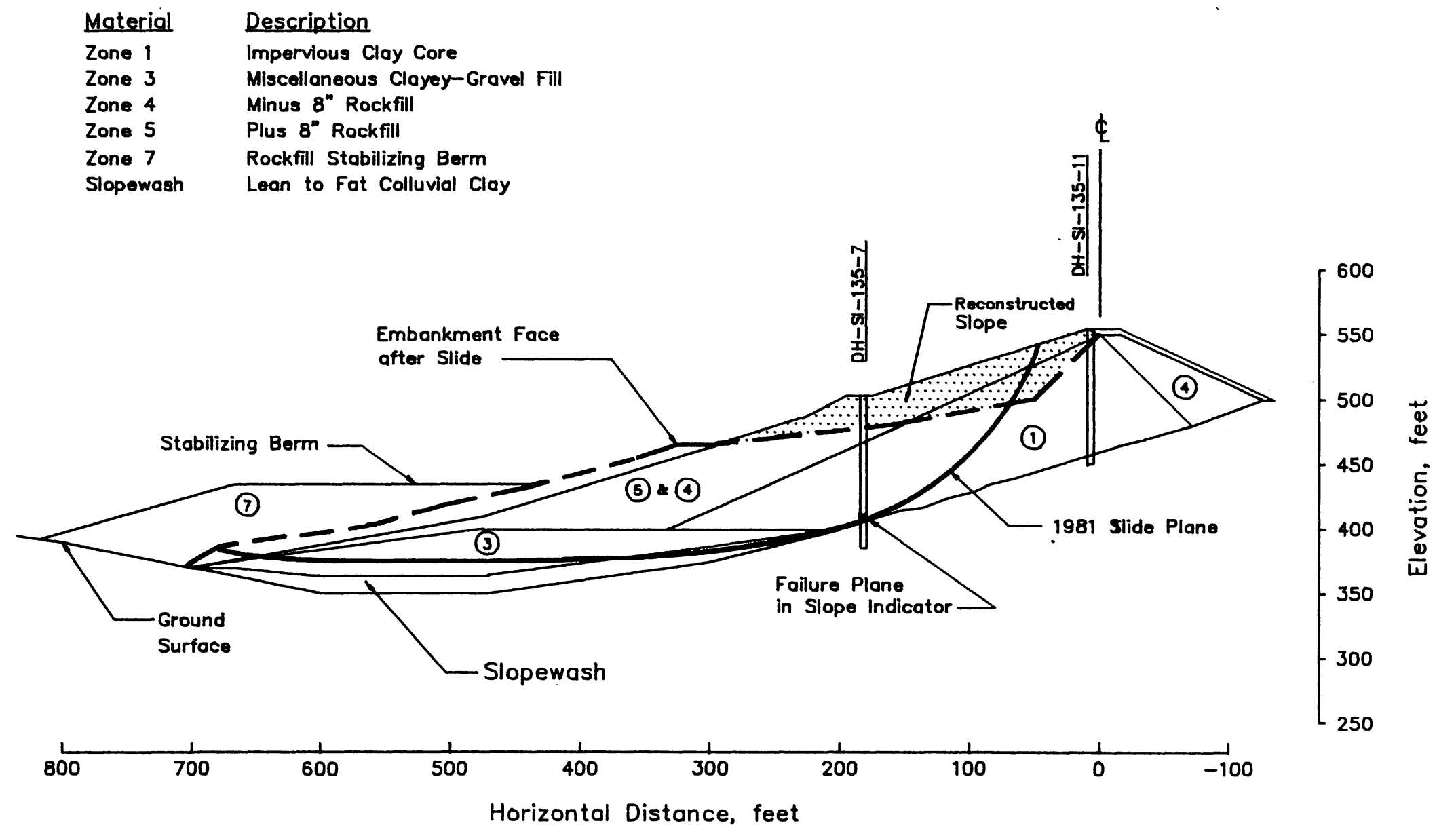

Figure 8-1 Upstream Slide and Repair at Station $135+00$ 
The finite element analyses were performed using the hyperbolic stress-strain model developed by Duncan, et al. (1980) and the plane strain finite element computer program FEADAM developed by Duncan, et al. (1984). The slope stability analyses were performed using the computer program SLOPE8R, which can be used to calculate the factors of safety for non-circular slip surfaces using Spencer's method. SLOPE8R was developed by Wright and Duncan (1968) and was subsequently adapted to the IBM PC by Wong and Duncan (1984).

Review of Movements Measured During the 1984 Drawdown

During the 1984 drawdown, movements were measured using two slope indicators, SI-135-7 and SI-135-11. The locations of these slope indicators are shown in Figure 81. Measurements were also made using 28 temporary survey points on the upstream slope and berm, and using Tell-Tales across the cracks on the crest of the embankment.

From Figure 8-2 it can be seen that slope indicator 135-7 recorded a shear displacement of about 2.5 inches from July 2 to August 10, 1984, at which time the device became inoperable. The movement occurred about 90 feet below the surface and, as shown in Figure 8-1, the elevation of the measured shear displacement corresponds to the elevation of the 1981 slide plane. Slope indicator 


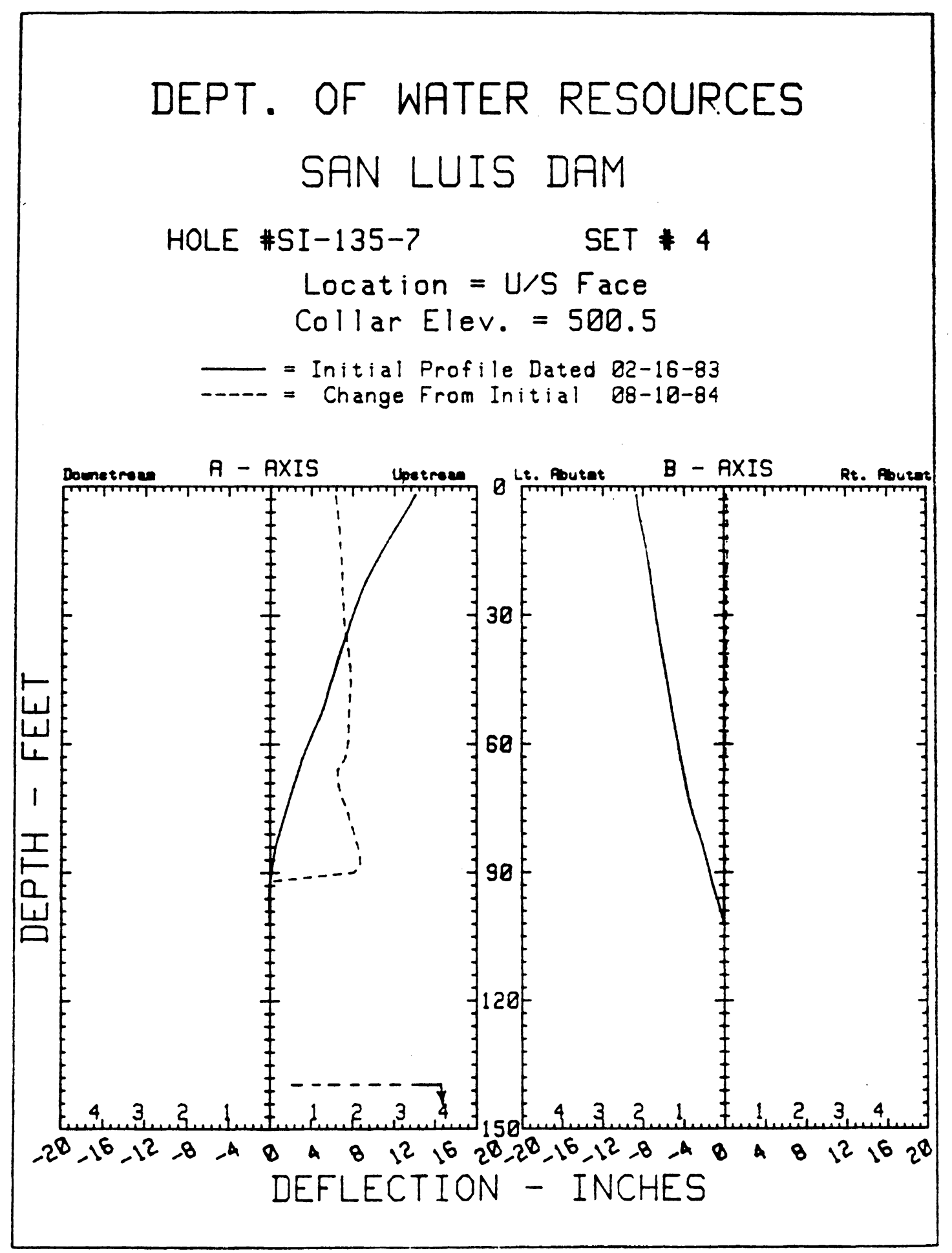

Figure 8-2 Slope Indicator $135-7$ at Station $135+\infty$ During 1984 Drawdown (Dept. of Water Resources, 1984) 
135-11 showed movement of 1.8 inches at the surface, as shown in Figure 8-3, and no movements at depths greater than about 15 feet beneath the surface. This depth corresponds approximately to the boundary between the old and new fill at this location, as may be seen in Figure 81 .

The longitudinal cracks in the crest, first observed on July 30, 1984, showed upstream horizontal movements of 0.4 to 0.75 inches with no perceptible vertical offset. The cracks at the crest were observed after 1.5 to 2.0 inches of subsurface movement had been measured in slope indicator 135-7, and development of the cracks is believed to have occurred as a result of movements of the old slide mass and the new fill in response to the 1984 drawdown. Surface surveys on the upstream face of the dam were conducted using 28 temporary survey points as mentioned previously. The measured displacements were erratic, as shown in Figure 8-4. The surface movements ranged from 0.5 to 1.3 inches, with the maximum occurring approximately 250 feet upstream from the crest. Calculated movements of the same points are also shown in Figure 8-4. These will be discussed in a later section. The survey points on the stabilizing berm were established on August 21, 1984, one day after drawdown was completed, and showed essentially zero lateral displacement. 


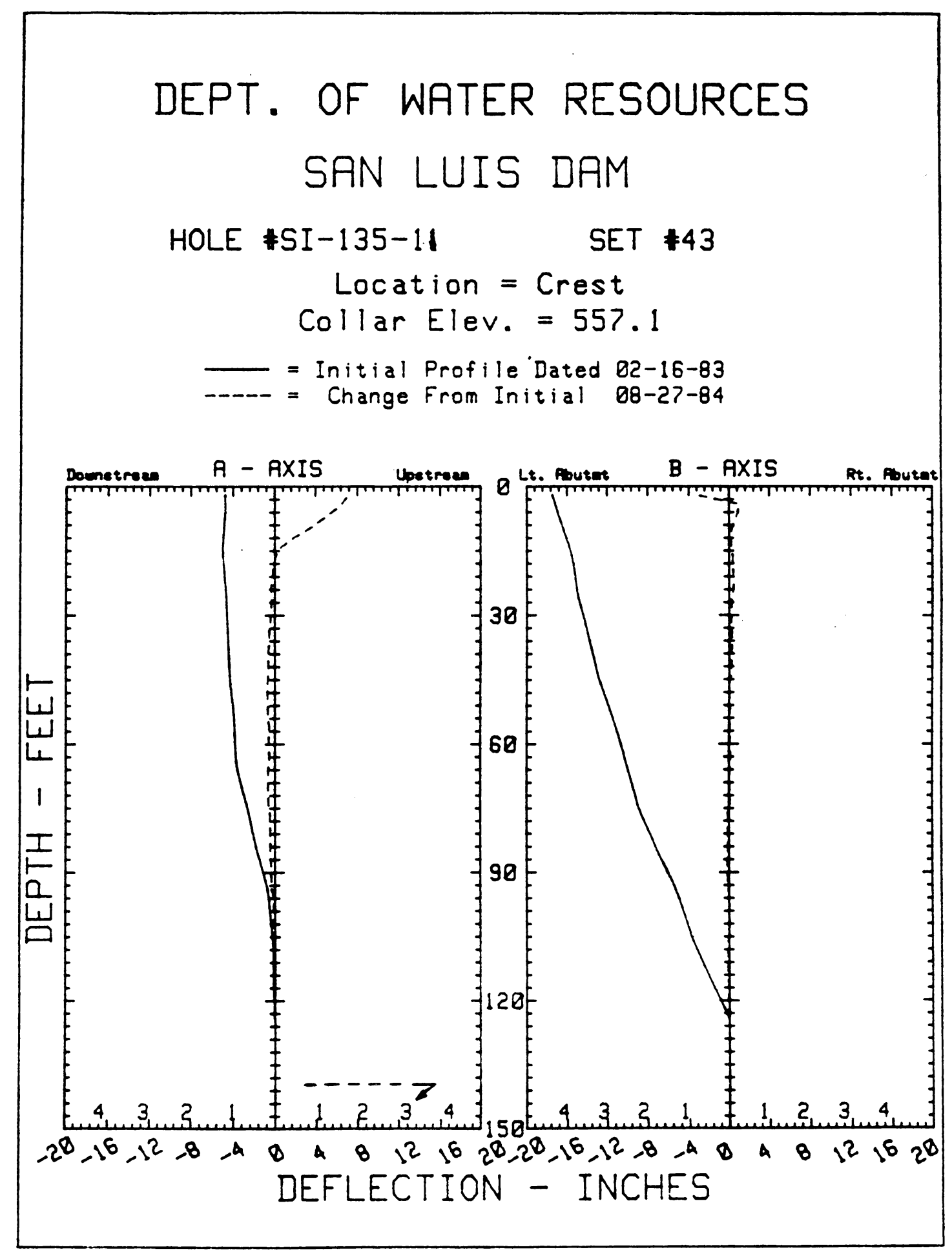

Figure 8-3 Slope Indicator 135-11 at Station 135+00 During 1984 Drawdown (Dept. of Water Resources, 1984) 


\begin{tabular}{|c|c|c|c|c|c|c|c|}
\hline \multirow{2}{*}{$\begin{array}{c}\text { Roint } \\
\text { A } \\
\text { B } \\
\text { C }\end{array}$} & \multicolumn{2}{|c|}{$\begin{array}{l}\text { Measured } \\
\text { Horizontal } \\
\text { (Inches) }\end{array}$} & \multicolumn{2}{|c|}{$\begin{array}{l}\text { ovements } \\
\text { Vertical } \\
\text { linches) }\end{array}$} & \multicolumn{2}{|c|}{$\begin{array}{l}\text { Calculated } \\
\text { Borizontal } \\
\text { (inches) }\end{array}$} & $\begin{array}{l}\text { Movements } \\
\text { Vertical } \\
\text { linches) }\end{array}$ \\
\hline & $\begin{array}{l}0.1 \\
0.2 \\
1.1 \\
1.3 \\
1.0 \\
1.1 \\
0.5\end{array}$ & $\begin{array}{l}D / S \\
D / S \\
0 / S \\
U / S \\
U / S \\
0 / S \\
0 / S\end{array}$ & $\begin{array}{l}0.0 \\
0.1 \\
0.2 \\
0.4 \\
1.1 \\
1.1 \\
0.7\end{array}$ & $\begin{array}{l}\text { Op } \\
\text { Op } \\
\text { Down } \\
\text { Down } \\
\text { Down } \\
\text { Down } \\
\text { Down }\end{array}$ & $\begin{array}{l}0.3 \\
0.9 \\
1.0 \\
1.2 \\
1.1 \\
0.8 \\
0.6\end{array}$ & $\begin{array}{l}0 / S \\
0 / S \\
U / S \\
U / S \\
0 / S \\
0 / S \\
U / S\end{array}$ & $\begin{array}{ll}0.1 & \text { Up } \\
0.4 & \text { Down } \\
1.2 & \text { Down } \\
1.5 & \text { Down } \\
1.2 & \text { Down } \\
0.8 & \text { Down } \\
0.7 & \text { Down }\end{array}$ \\
\hline
\end{tabular}

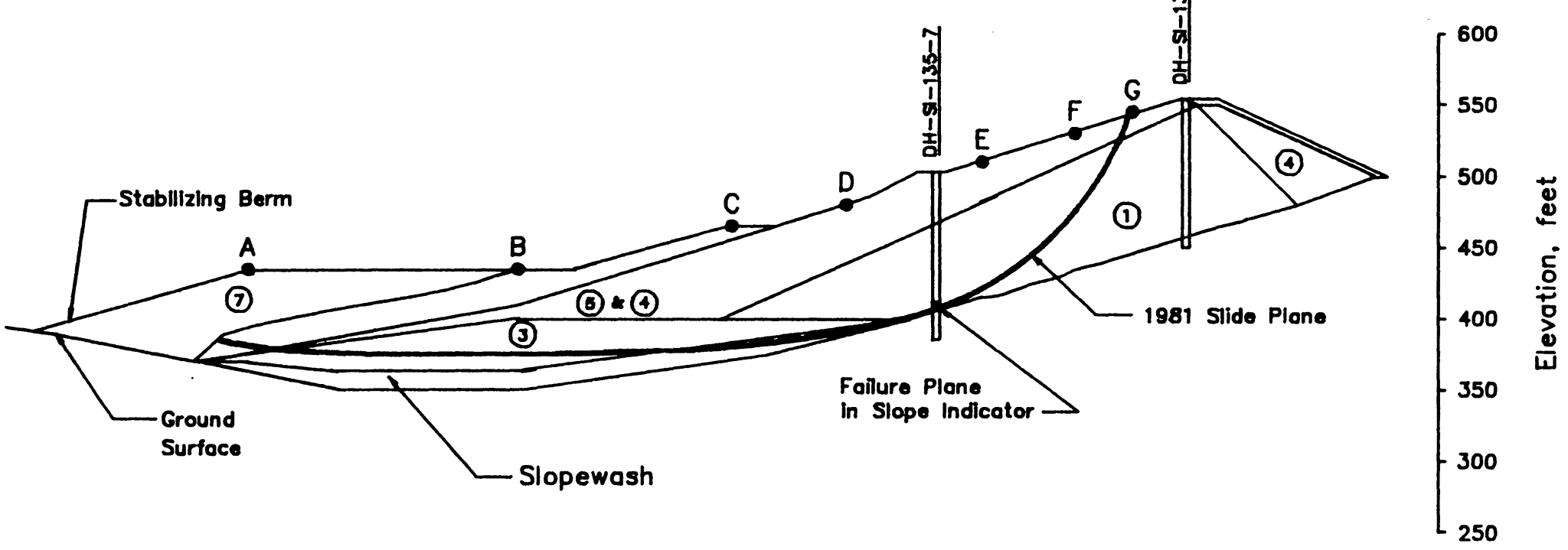

Figure 8-4 Measured and Calculated Movements of Selected Surface Points, Station 135+00, San Luis Dam 
The movements observed during the 1984 drawdown are summarized in Table $8-1$, and appear to be caused by the old slide mass moving downward and in the upstream direction. The finite element analyses described in the following sections were conducted to gain a better understanding of the nature of the 1984 movements, and to estimate the possible magnitudes of movements during subsequent large drawdown cycles.

\section{Finite Element Model}

The 1984 drawdown was modeled using two stages: 1) a "build-up" analysis was performed to establish the stresses in the embankment with the reservoir full and 2) then nodal point forces were applied to simulate the changes in load that occurred during drawdown.

In the "build-up" analyses, construction of the embankment was simulated using nine layers, with buoyant unit weights assigned to all materials below the phreatic surface. Although this analysis did not follow the actual loading sequence, (embankment construction followed by reservoir filling), previous studies have shown that the simpler analysis procedure results in reasonably accurate values of the stresses in the embankment and is therefore a valid procedure for establishing the stress conditions in the embankment prior to drawdown. 
TABLE 8-1 - Surface and Subsurface Movements Measured During the 1984 Drawdown

Measurement

Slope Indicator 135-7

Crest Cracks

Upstream Slope

Surveys

Slope Indicator 135-11
Measured Movement

2.5 inches along existing slide plane

0.5 inches wide with no vertical offset

1.0 inch of upstream movement with berm stationary

1.8 inches of upstream movement at the crest

* Measured Movements, from Department of Water Resources, (1984) and (1985). 
The 1984 reservoir drawdown, from elevation 545 to elevation 435 feet, was simulated by applying five increments of loading. The nodal point forces used in each load increment were calculated to simulate the changes in seepage and buoyancy forces resulting from the drawdown. The seepage forces were determined from hydraulic gradients calculated in the seepage analysis described in Chapter 4. The hydraulic gradient through the rockfill material was essentially zero due to its large permeability.

\section{Soil Properties for Analysis}

The values of the drained hyperbolic stress-strain parameters used to represent the slopewash and the slide plane material are shown in Table 8-2. These parameter values were determined from the results of laboratory tests on the slopewash described in previous chapters. The drained hyperbolic parameters used for the embankment and berm materials, which are shown in Table 8-3, were developed by Morfitt (1985) and Von Thun (1985) for use in their analyses of the dam.

\section{Analysis Procedure}

The finite element mesh used in the analyses is shown in Figure 8-5. The slide plane through the slopewash and the zone 3 material was modeled using a row of elements two 

TABLE 8-2 - Drained Hyperbolic Stress-Strain Parameters
for the Slopewash and Slide Zone Materials

\begin{tabular}{|c|c|c|c|}
\hline $\begin{array}{l}\text { Hyperbolic } \\
\text { Parameter }\end{array}$ & $\begin{array}{c}\text { Initial Values } \\
\text { Used for } \\
\text { Slide Zone } \\
\text { \& Slopewash } \\
\text { Material }\end{array}$ & $\begin{array}{c}\text { Adjusted } \\
\text { Values for } \\
\text { Slide Zone } \\
\text { Material }\end{array}$ & $\begin{array}{l}\text { Adjusted } \\
\text { Values for } \\
\text { Slopewash }\end{array}$ \\
\hline $\begin{array}{l}\text { Density } \\
(1 \mathrm{~b} / \mathrm{cu} \mathrm{ft})\end{array}$ & 125 & 125 & 125 \\
\hline $\begin{array}{l}\text { Cohesion } \\
(1 \mathrm{~b} / \mathrm{sq} \mathrm{ft})\end{array}$ & 0 & 0 & 0 \\
\hline $\begin{array}{l}\text { Friction Angle } \\
\text { (degrees) }\end{array}$ & 26 & 15 & 26 \\
\hline $\begin{array}{l}\text { Modulus Numbers } \\
\text { Loading } \\
\text { Unloading }\end{array}$ & $\begin{array}{l}200 \\
450\end{array}$ & $\begin{array}{l}5 \\
5\end{array}$ & $\begin{array}{r}25 \\
100\end{array}$ \\
\hline Modulus Exponent & 0.6 & 0.1 & 0.53 \\
\hline Failure Ratio & 0.85 & 0.85 & 0.85 \\
\hline $\begin{array}{l}\text { Bulk Modulus } \\
\text { Number } \\
\text { Exponent }\end{array}$ & $\begin{array}{l}195 \\
1.0\end{array}$ & $\begin{array}{r}5 \\
0.1\end{array}$ & $\begin{array}{l}100 \\
0.5\end{array}$ \\
\hline $\begin{array}{l}\text { Earth Pressure } \\
\text { Coefficient, } k_{0}\end{array}$ & 0.65 & 0.65 & 0.65 \\
\hline
\end{tabular}


TABLE 8-3 - Drained Hyperbolic Stress-Strain Parameters for the Embankment and Berm Materials

\begin{tabular}{|c|c|c|c|c|}
\hline $\begin{array}{l}\text { Hyperbolic } \\
\text { Parameter }\end{array}$ & $\begin{array}{l}\text { Drained } \\
\text { Zone } 1\end{array}$ & $\begin{array}{l}\text { Drained } \\
\text { Zone } 3 \\
\end{array}$ & $\begin{array}{l}\text { Drained } \\
\text { Zones } 4 \quad \& \quad 5 \\
\end{array}$ & $\begin{array}{c}\text { Drained } \\
\text { Berm }\end{array}$ \\
\hline $\begin{array}{l}\text { Density } \\
(1 \mathrm{~b} / \mathrm{cu} \mathrm{ft})\end{array}$ & 135 & 135 & 140 & 135 \\
\hline $\begin{array}{l}\text { Cohesion } \\
(1 \mathrm{~b} / \mathrm{sq} \mathrm{ft})\end{array}$ & 0 & 0 & 0 & 0 \\
\hline $\begin{array}{l}\text { Friction Angle } \\
\text { (degrees) }\end{array}$ & 25 & 20 & 40 & 35 \\
\hline $\begin{array}{l}\text { Modulus Numbers } \\
\text { Loading } \\
\text { Unloading }\end{array}$ & $\begin{array}{r}250 \\
2000\end{array}$ & $\begin{array}{r}99 \\
200\end{array}$ & $\begin{array}{l}450 \\
900\end{array}$ & $\begin{array}{l}450 \\
900\end{array}$ \\
\hline Modulus Exponent & 0.2 & 0.7 & 0.37 & 0.37 \\
\hline Failure Ratio & 0.78 & 0.86 & 0.61 & 0.61 \\
\hline $\begin{array}{l}\text { Bulk Modulus } \\
\text { Number } \\
\text { Exponent }\end{array}$ & $\begin{array}{l}223 \\
0.03\end{array}$ & $\begin{array}{r}45 \\
0\end{array}$ & $\begin{array}{l}225 \\
0.18\end{array}$ & $\begin{array}{l}225 \\
0.18\end{array}$ \\
\hline $\begin{array}{l}\text { Earth Pressure } \\
\text { Coefficient, } k_{0}\end{array}$ & 0.8 & 0.8 & 0.67 & 0.67 \\
\hline
\end{tabular}

Parameter values from Morfitt (1985) and Von Thun (1985). 


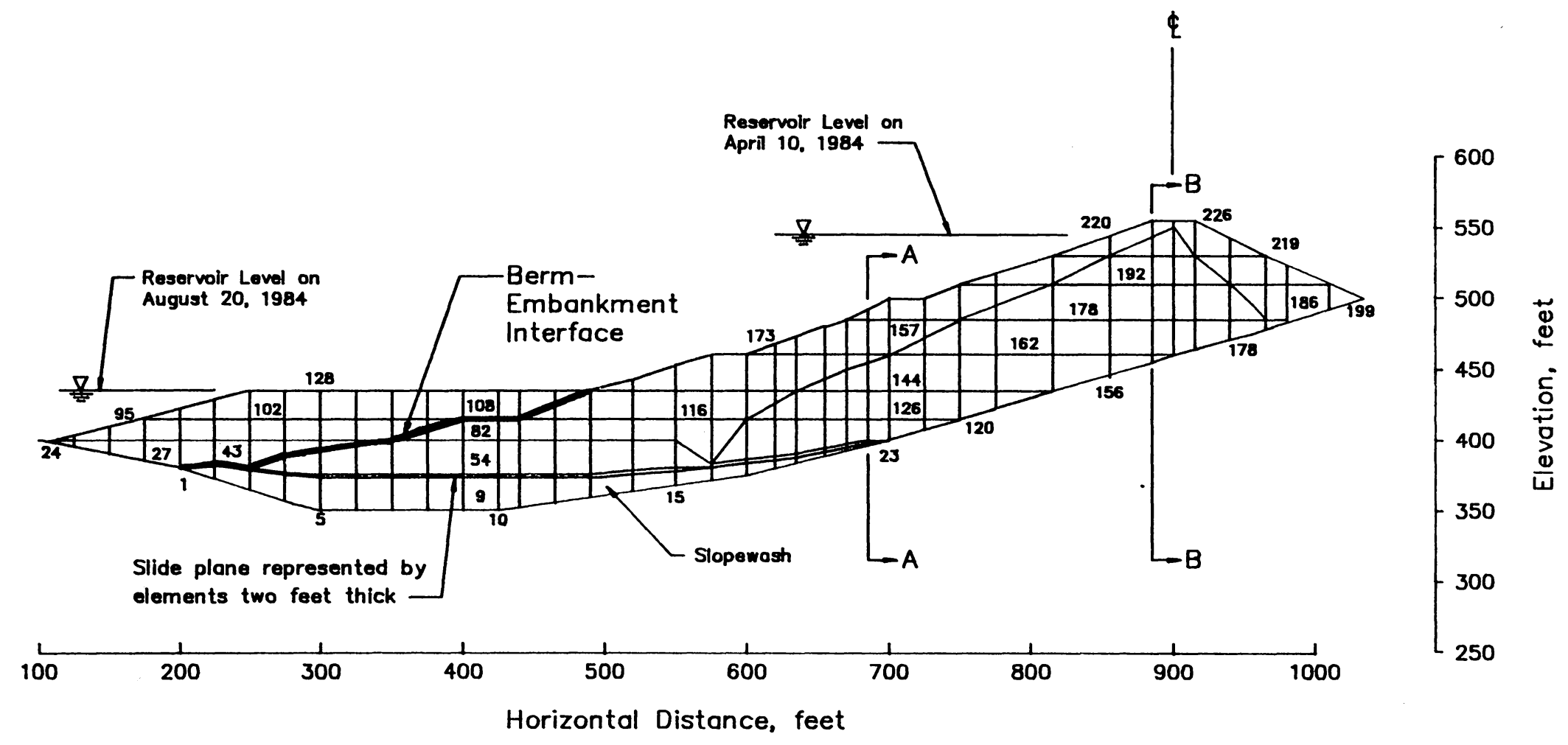

Figure 8-5 Finite Element Mesh for Analysis of 1984 Movements at Station $135+00$ 
feet thick. Since most of the $\mathrm{Z}$ one 1 material was replaced during the reconstruction, the slide plane in Zone 1 was not represented by the thin elements, and the row of special slide plane elements stopped at the upstream boundary of Zone 1 .

The 1984 drawdown was the first loading of the stabilizing berm and the first reloading of the slide plane material after the 1981 slide. These materials were therefore assigned primary loading modulus values. The embankment materials and the slopewash outside the slide plane were being reloaded during the 1984 drawdown and were therefore assigned unload-reload modulus values. In the analyses performed to examine possible behavior in future large drawdown cycles, all of the materials were assigned unload-reload modulus values.

\section{Calculated Movements During 1984 Drawdown}

In the finite element mesh shown in Figure 8-5, Section A-A represents the location of slope indicator 1357. The horizontal movement calculated on the slide plane using the soil parameters in Tables $8-2$ and 8-3 was about 0.3 inches, which was considerably less than the 2.5 inches that was measured. To establish better agreement between the calculated and measured displacements, the modulus values of the slopewash and slide plane material were 
varied. After several trials the horizontal displacements calculated at section $A-A$ were in good agreement with the measured displacements, as shown in Figure 8-6. The hyperbolic parameters for the slopewash and the slide plane material used in the match are shown in Table 8-2. These are referred to as the adjusted parameter values.

As shown in Figure 8-4, the calculated surface movements are in fairly good agreement with the surface survey. The calculated horizontal displacements at the crest were also in reasonable agreement with the displacements observed in slope indicator SI-135-11, as can be seen in Figure 8-7. The difference in the calculated and measured movements may be due to the effects of the cracks observed in the crest of the dam. No attempt was made to simulate cracking in the finite element analyses. In summary, the finite element model used in these analyses appears to provide a reasonable representation of the behavior of the embankment during the 1984 drawdown.

Using the calibrated finite element model the horizontal displacements and stresses were calculated along the berm-embankment interface as shown in Figure 8-5. The calculated horizontal displacements shown in Figure 8-8 indicate the slide mass moved horizontally against the berm about one inch during the drawdown. The calculated movements decreased from about one inch at the surface to 


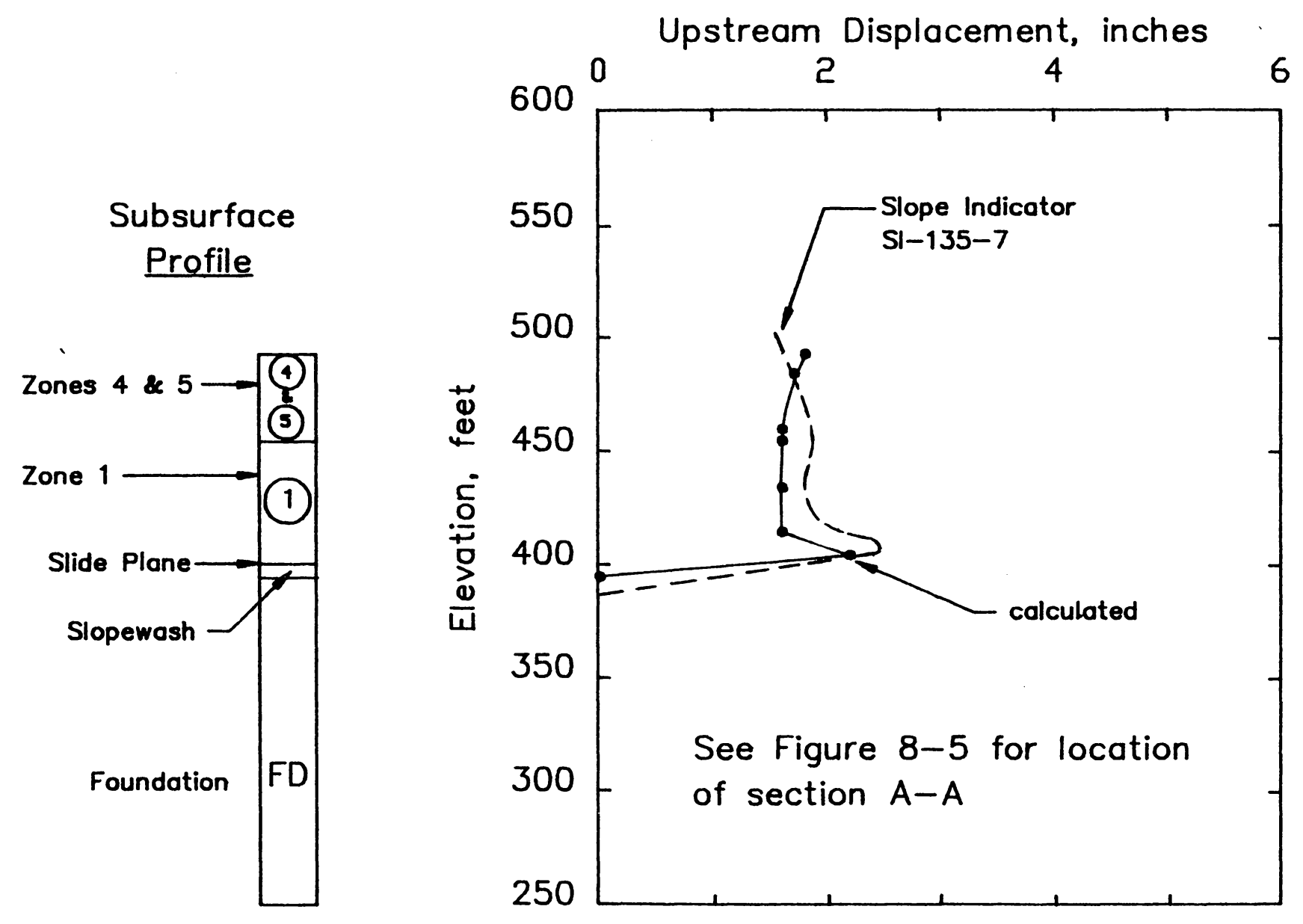

Figure 8-6 Comparison of Measured and Calculated Displacements Along Section A-A at Station $135+00$ 

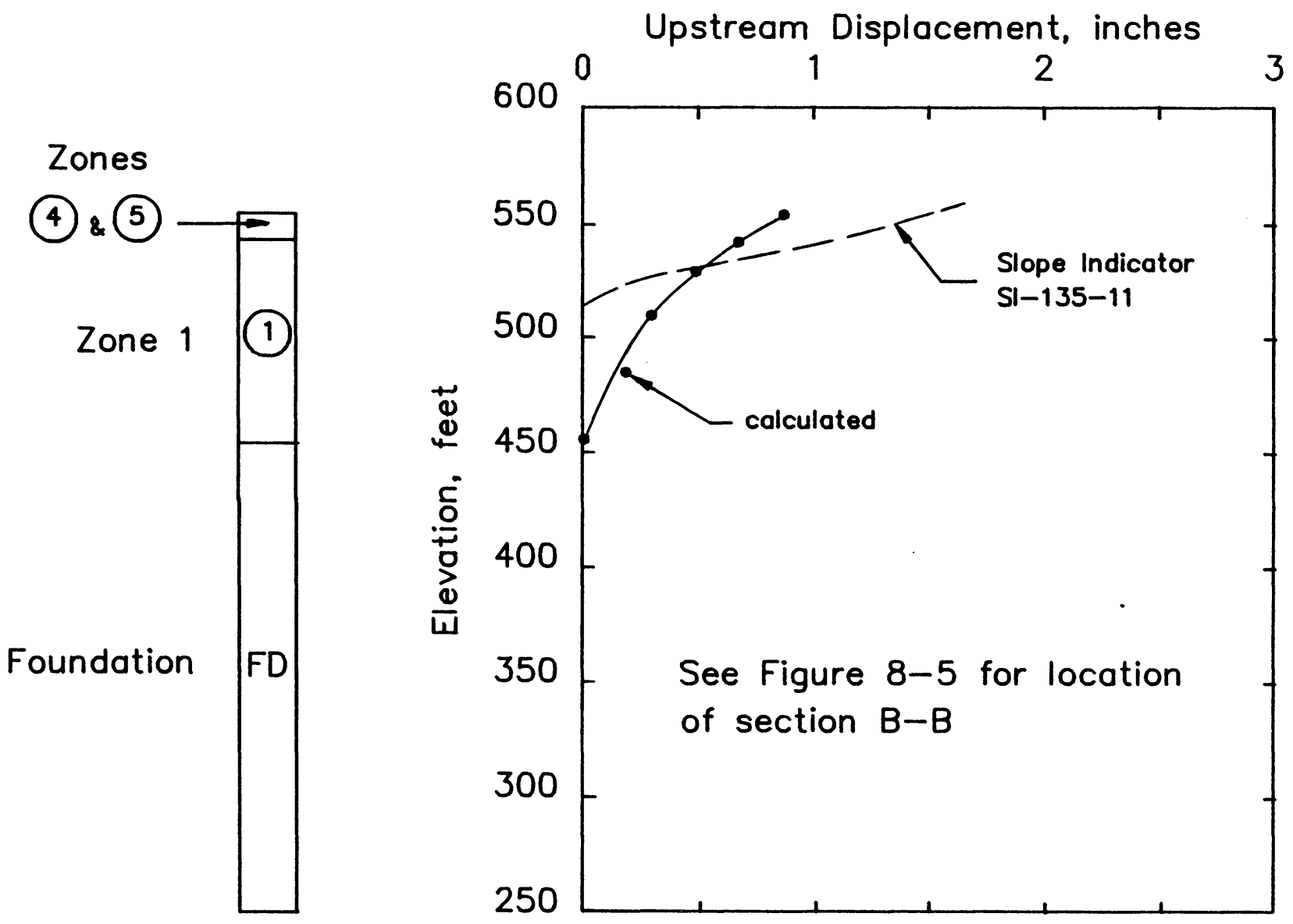

Figure 8-7 Comparison of Measured and Calculated Displacements Along Section B-B at Station $135+00$ 


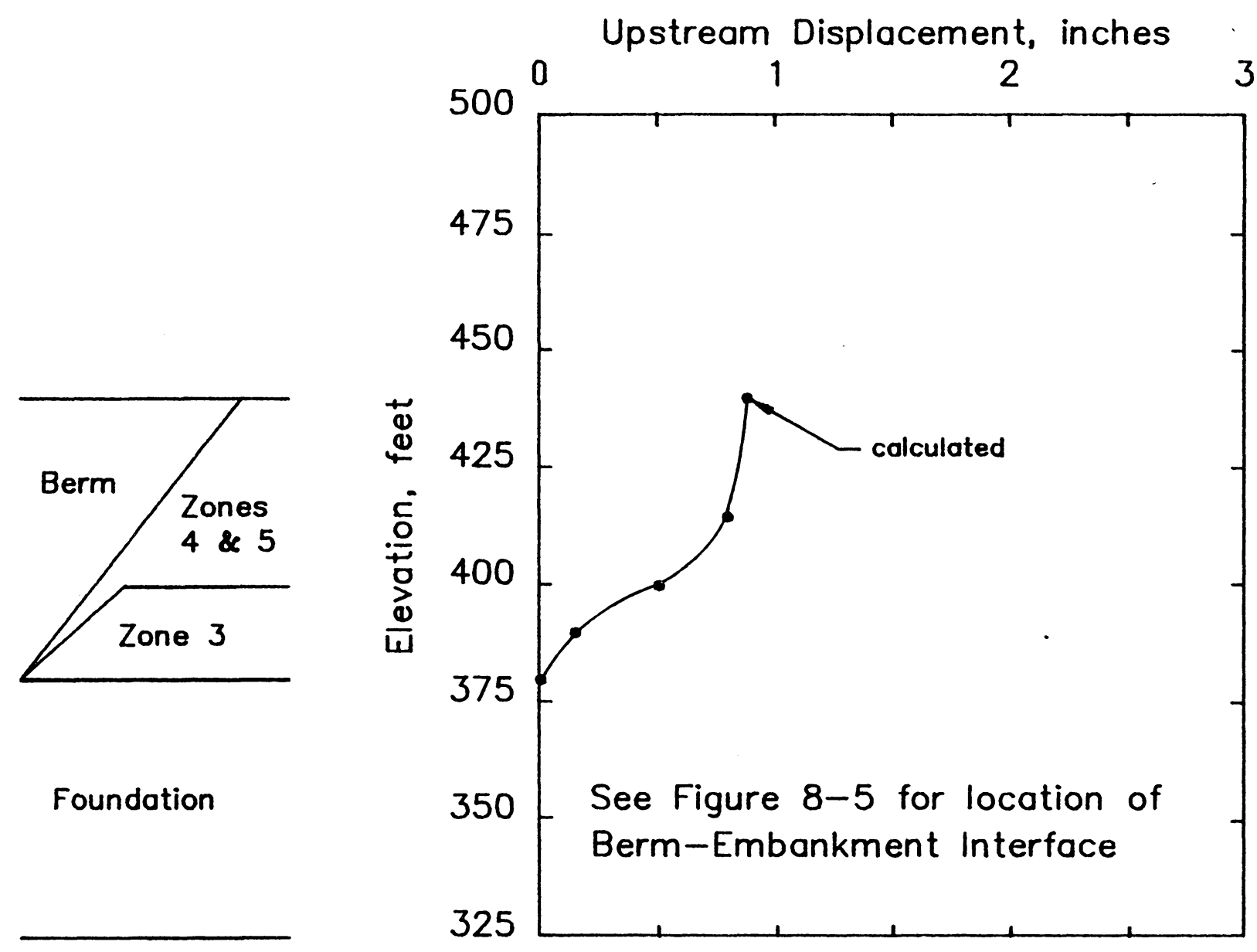

Figure 8-8 Calculated Displacements Along Berm-Embankment Interface at Station $135+00$ 
zero at the foundation. Much of the movement occurred in Zone 3, near the slide plane, and the overlying zones 4 and 5 moved essentially as rigid block. As shown in Figure 84, the finite element model also indicates that the horizontal shift of the slide mass and the berm was accompanied by small vertical movements.

The finite element calculations showed there was a substantial increase in the horizontal stresses along the berm-embankment interface due to the 1984 drawdown. As shown in Figure 8-9 there was an average increase in the horizontal stress of about 600 psf along the interface between the embankment and the berm. The vertical stress remained practically unchanged.

Thus, the finite element analyses of the 1984 drawdown indicate the embankment and berm are undergoing a natural readjustment process in which the old slide mass is moving slightly against the berm and transferring load to it.

\section{Estimated Performance of San Luis Dam During Future Large Drawdown Cycles}

To investigate the performance of San Luis Dam to be expected during future large drawdown cycles, additional finite element analyses were performed. In these analyses all of the materials in the embankment, the berm, and the slide plane were assigned unload-reload modulus values. The modulus number and bulk modulus number of the slide 


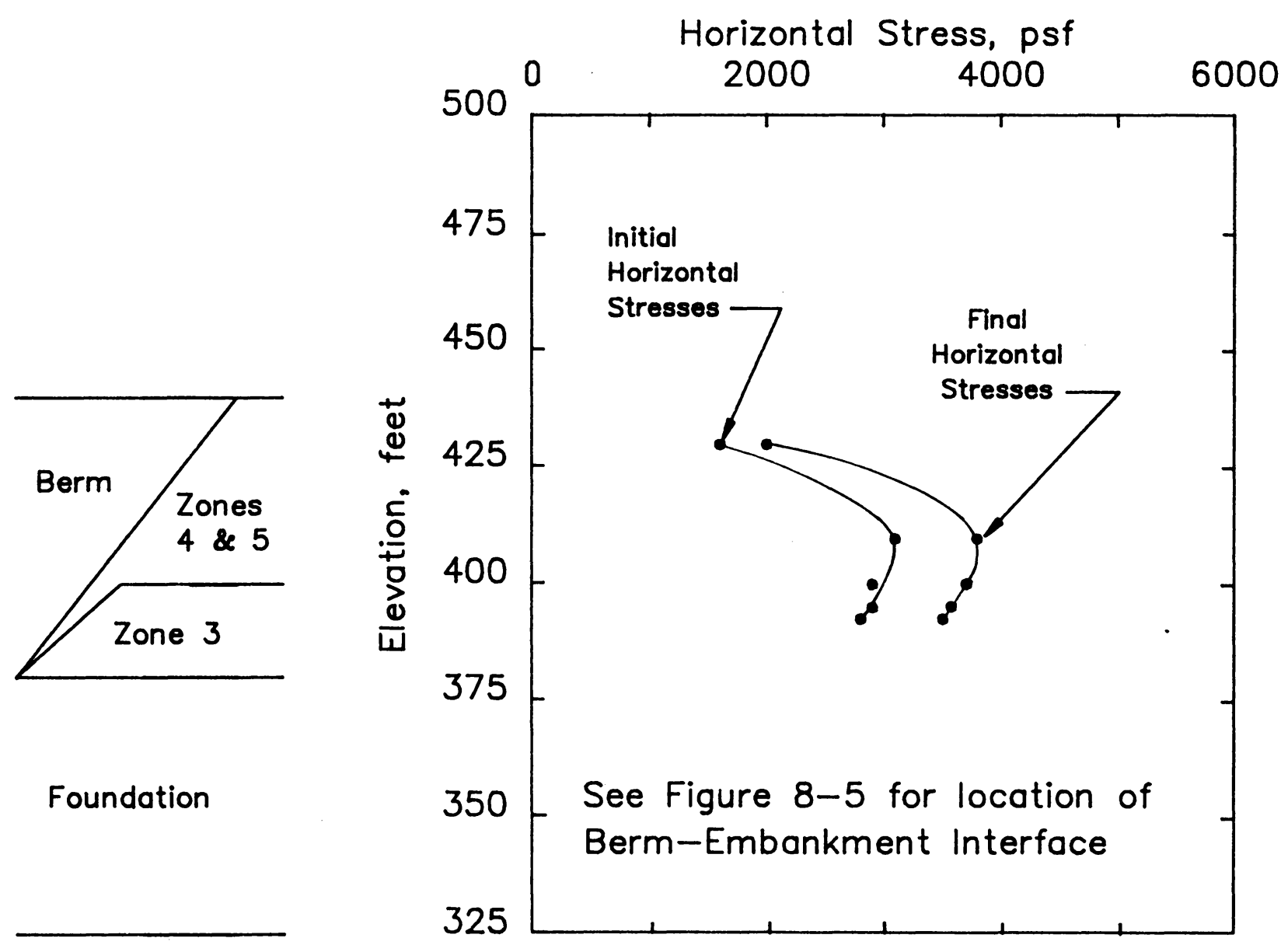

Figure 8-9 Calculated Horizontal Stresses Along BermEmbankment Interface at Station 135+00 
plane material was increased from 5 to 15 to reflect an increase in stiffness during reloading. The other adjusted soil properties shown in Table $8-2$ and the embankment parameters in Table 8-3 were used in the analysis.

It can be seen from Figure 8-10 that the horizontal displacements calculated along section $A-A$ were approximately 408 smaller than the displacements calculated for the 1984 drawdown. However, as shown in Figure 8-11, the displacements along section $B-B$ did not change significantly, because the core and shell material had been assigned unload-reload modulus values during the analyses of the 1984 drawdown.

These finite element analyses indicated that the horizontal displacements and stresses along the embankmentberm interface are likely to be smaller during future large drawdown cycles than during the 1984 drawdown. As shown in Figure 8-12, the calculated horizontal displacements along the berm interface are about $15 \%$ smaller than those calculated for the 1984 drawdown. The changes in horizontal stress also decreased slightly as shown in Figure 8-13.

These analyses indicate that movements will continue to occur in the embankment and berm during each drawdown cycle. The movements during subsequent drawdown cycles are expected to be smaller than those that occurred during the 


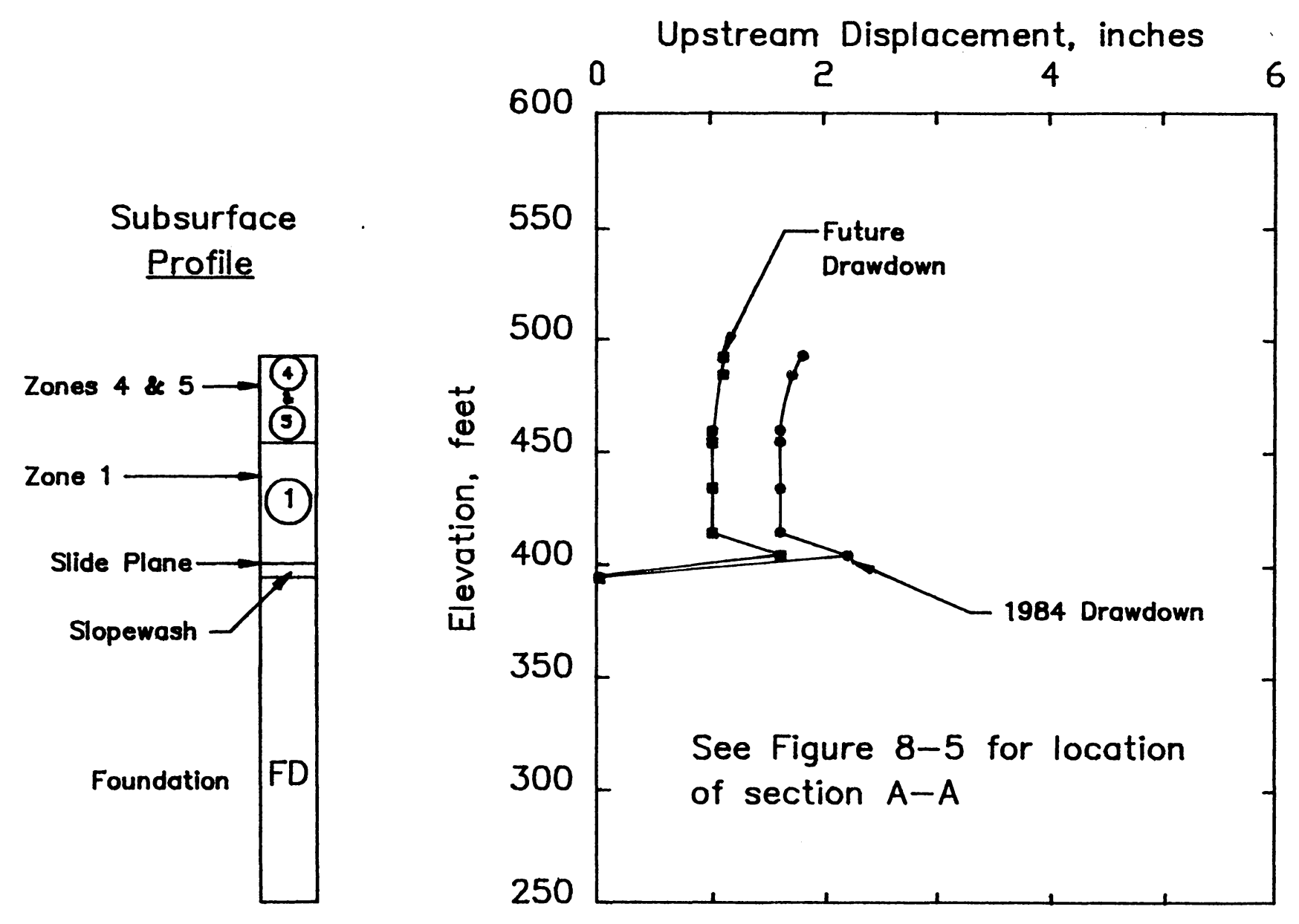

Figure 8-10 Calculated Possible Displacements Along Section A-A at Station 135+00 During Future Drawdowns 

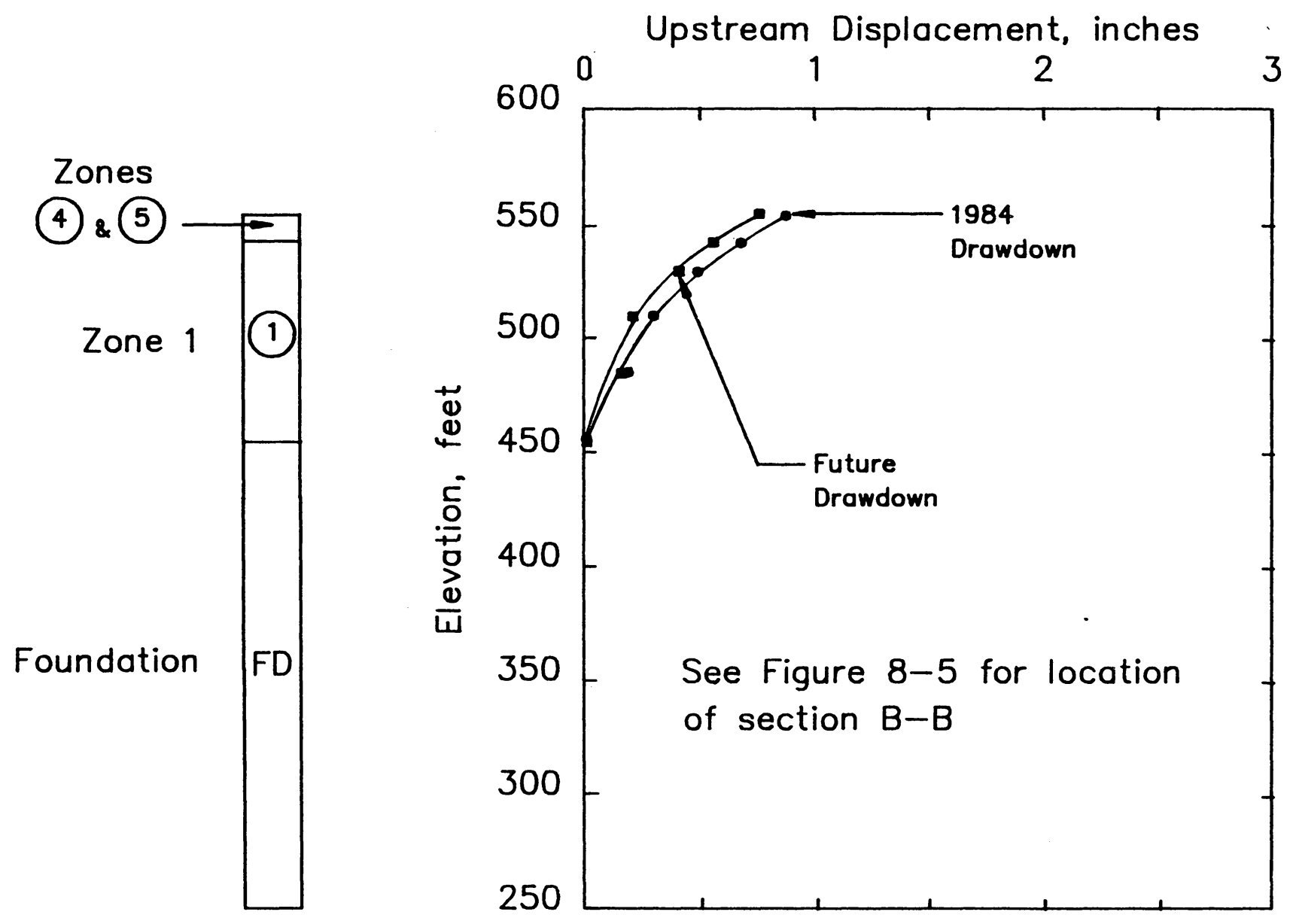

Figure 8-11 Calculated Possible Displacements Along Section $\mathrm{B}-\mathrm{B}$ at Station $135+00$ During Future Drawdowns 


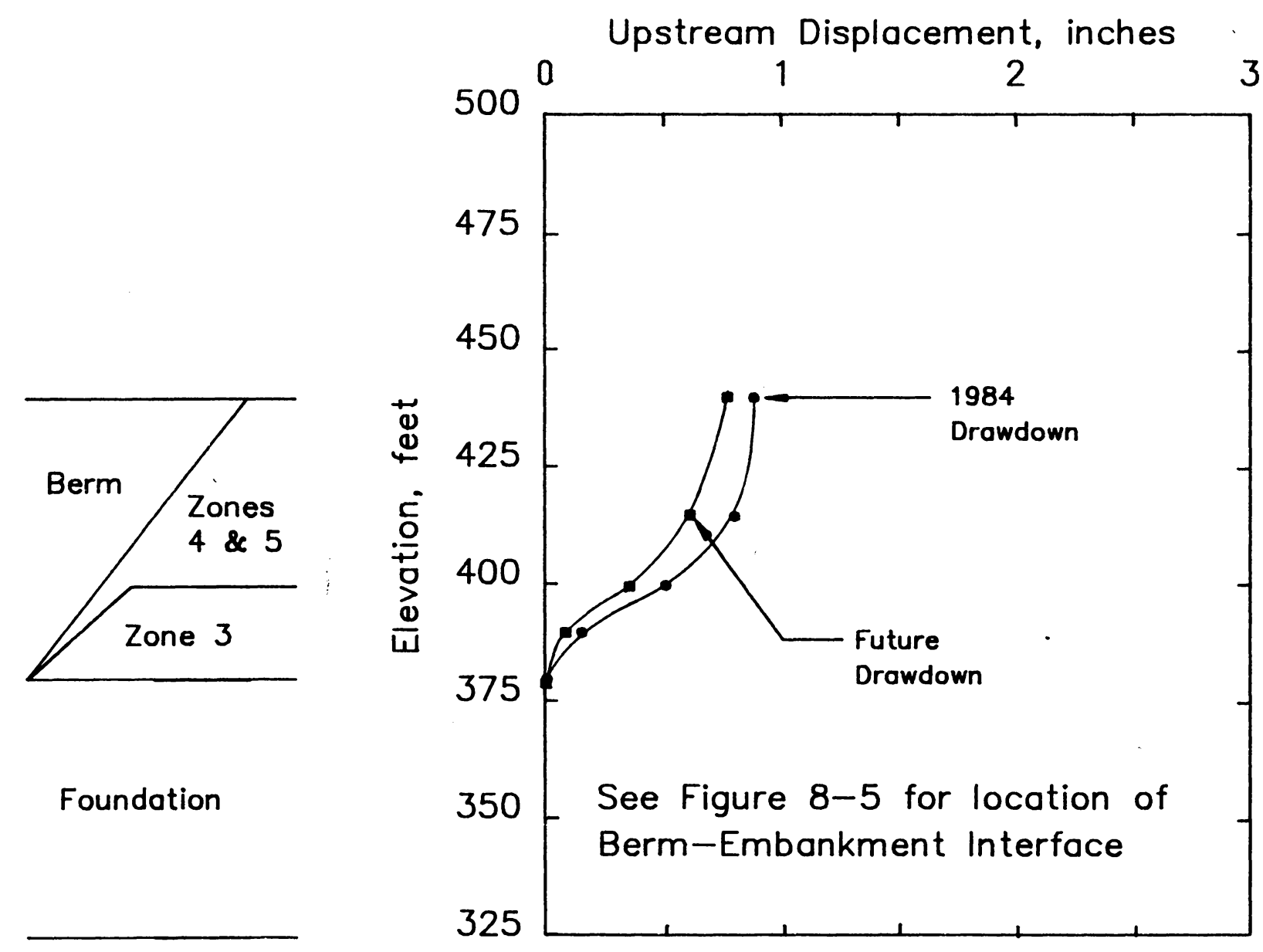

Figure 8-12 Calculated Possible Displacements Along Berm-Embankment Interface at Station 135+00 During Future Drawdowns 


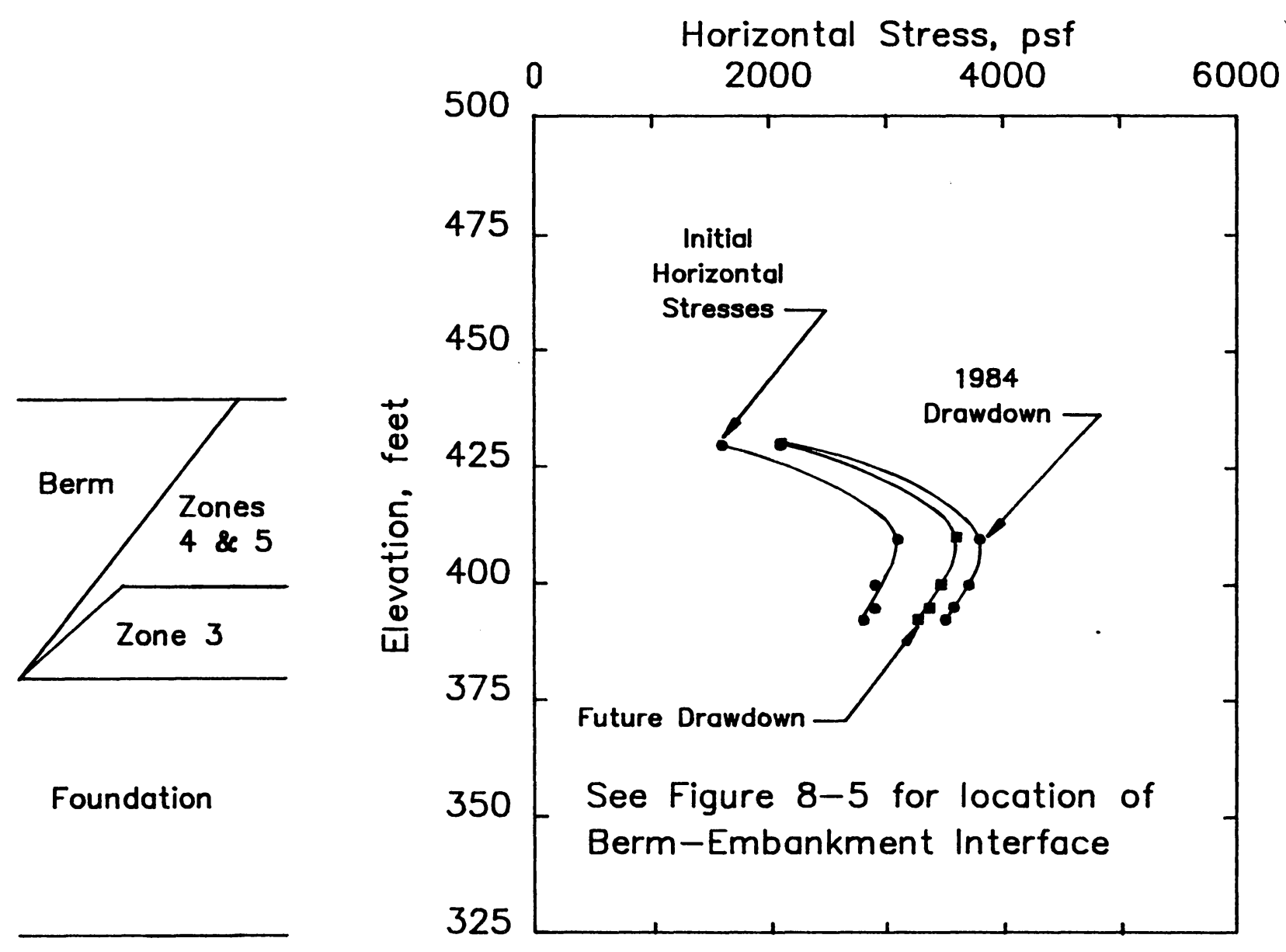

Figure 8-13 Calculated Possible Changes in Horizontal Stresses Along Berm-Embankment Interface During Future Drawdowns 
1984 drawdown.

\section{Stability of San Luis Dam}

Slope stability analyses were conducted to determine the factor of safety of the upstream slope during the 1984 drawdown. The critical condition was when the reservoir reached elevation 435 feet (the elevation of the top of the berm) because as the reservoir passed below this elevation the berm began to emerge above water, and its effective weight began to increase.

Stability analyses were performed using the shear strength parameters shown in Table 8-4, together with the "medium" or most probable pore pressure condition, shown in Figure 4-32. The pore pressures in the zone 1 material were those shown in Figure 4-33.

As shown in Table 8-5, factors of safety were calculated for two slide planes shown in Figure 8-14. The 1981 slide plane was found to have a factor of safety of 1.21. The steeper slide plane, passing downstream from the berm, was found to have a factor of safety of 1.26. Thus, the 1981 slide plane appears to be the more critical plane of sliding, indicating that a failure that might circumvent the stabilizing berm is not likely. 
TABLE 8-4 - Drained Shear Strength Parameters for the Slopewash and Embankment Materials used in Stability Analyses *

\begin{tabular}{lccc} 
Material & $\begin{array}{c}\text { Density } \\
\text { (lb./cu.ft) }\end{array}$ & $\begin{array}{c}\text { Cohesion } \\
\text { (lb./sq.ft.) }\end{array}$ & $\begin{array}{c}\text { Friction Angle } \\
\text { (degrees) }\end{array}$ \\
Slopewash & 125 & 0 & 15 \\
Zone 3 & 135 & 0 & 15 \\
$\begin{array}{l}\text { Zone 1 } \\
\text { (failed) }\end{array}$ & 135 & 0 & 20 \\
$\begin{array}{l}\text { Zone 1 } \\
\text { (unfailed) }\end{array}$ & 135 & 0 & 25 \\
Berm & 135 & 0 & 35 \\
\hline
\end{tabular}

* Parameter values were used by Von Thun, (1985). 
TABLE 8-5 - Factors of Safety for the Upstream Slope During the 1984 Drawdown

Calculated

Slide Plane

1981 Slide Plane

Steep Slide Plane

1.26

Factors of safety were calculated using the slide planes shown in Figure 8-14, the shear strength parameters in Table $8-3$, and the medium pore pressure condition. 


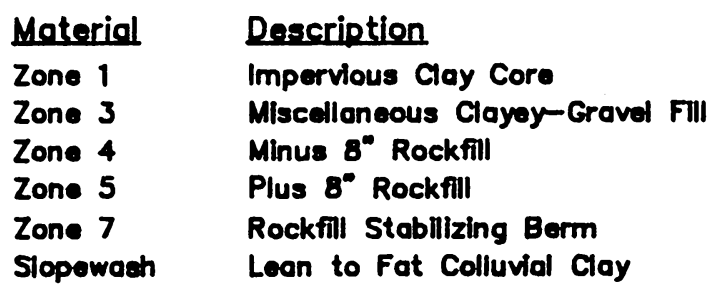

Zone 4

Zone 5

Zone 7

Slopowach

Impervious Clay Coro

Miscellaneous Clayey-Gravel Fill

Minus 8" Rockfill

Plus 8" Rockfill

Rockfill Stabllizing Berm

Leon to Fat Colluvial Clay

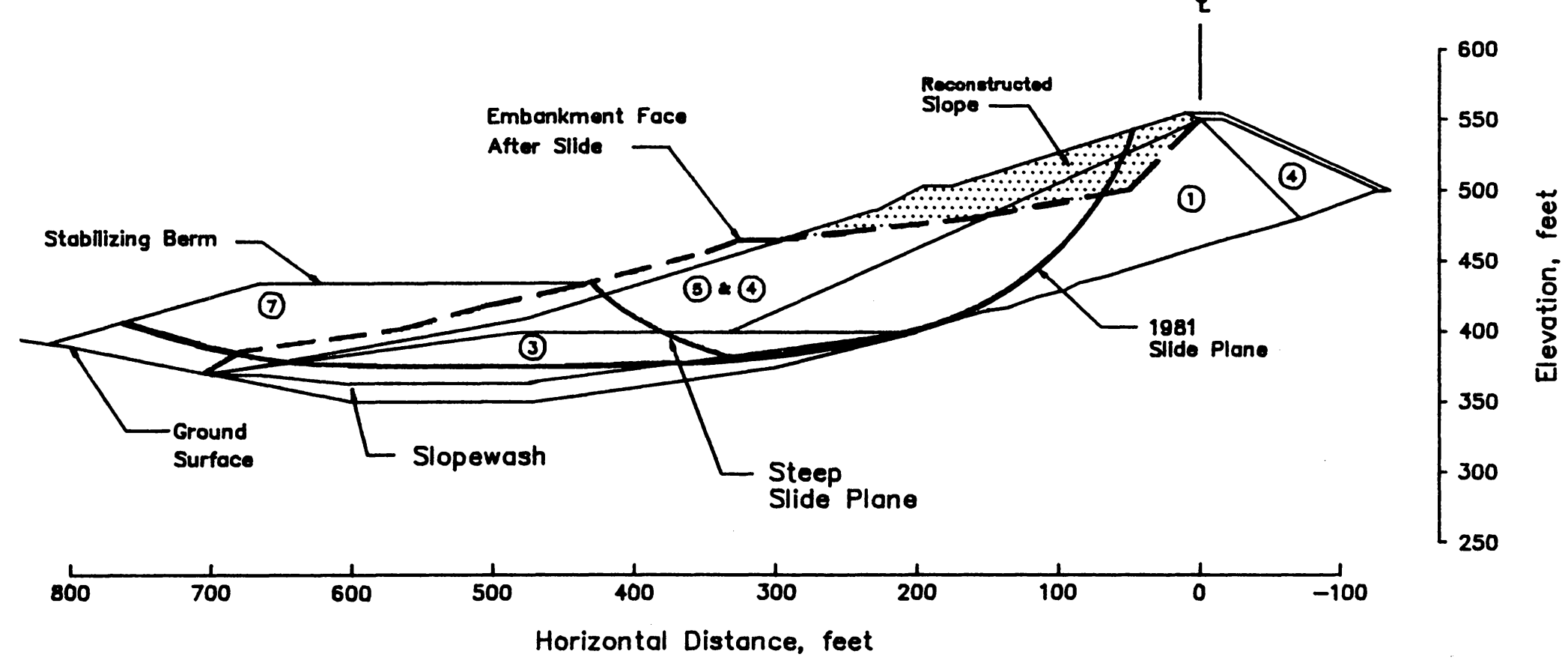

Figure 8-14 Slide Planes Used in Stability Analyses, Station 135+00 


\section{Summary}

The movements observed during the 1984 drawdown appear to result from a process of transferring load from the old slide mass to the berm. Finite element analyses showed the same type of movements as measured in the field, with the slide mass moving laterally against the berm, causing a substantial transfer of load to the berm. Movements will probably occur during future drawdown cycles, but they are expected to be smaller than those that occurred during the 1984 drawdown. Stability analyses indicate that the berm provides sufficient stabilizing effect to maintain stability of the slope during large drawdown cycles. 


\section{CHAPTER NINE - Conclusions}

The objective of this study was to gain a better understanding of the mechanisms of strength loss in the slopewash in the foundation of San Luis Dam, and the relationship of this loss in strength to the occurrence of the slide in the upstream slope in 1981. The study involved laboratory tests on undisturbed samples of slopewash, finite element analyses of nonsteady seepage through the embankment and its foundation, finite element analyses of the stresses in the dam during construction and operation of the reservoir, and equilibrium slope stability analyses.

\section{Conventional Consolidation and Direct Shear Tests}

The first part of the study consisted of performing a series of consolidation and direct shear tests on undisturbed specimens of slopewash taken from the foundation of the dam. The samples tested were from downstream, where the slopewash was still in a desiccated condition, and from upstream, where the slopewash had been soaked by the reservoir. The major conclusions derived from these tests are:

1) In its desiccated state the San Luis Dam slopewash 
has very high shear strength and very low compressibility. These properties apparently result from the dense condition of the desiccated clay and the large suction in the small amount of water remaining in the clay in its desiccated condition.

2) Soaking results in rapid expansion of the clay, greatly reduced shear strength, and greatly increased compressibility. After soaking, the clay behaves almost as a normally consolidated material. Soaking reduces the shear strength of the desiccated slopewash to its fully softened strength, the same as the shear strength of the clay when completely remolded.

3) Although mechanically overconsolidated specimens of the clay have smaller peak strengths than desiccated specimens at the same void ratio, their strengths are unaffected by soaking. The peak strength of mechanically overconsolidated specimens considerably exceeded their fully softened peak strengths.

\section{Transient Seepage Analyses}

The second part of the study involved evaluation of field piezometric measurements and a transient seepage 
analysis to determine the pore pressures in the foundation slopewash and the clay core of San Luis Dam at the time of the 1981 slide. The main conclusions from these studies are:

1) Field measurements made after the 1981 slide showed significant time lag in pore pressure response during drawdown.

2) Transient seepage analyses calibrated to the field measurements indicated that significant excess pore pressures existed in the slopewash and clay core at the time of the 1981 slide.

3) The transient seepage analyses indicated that the phreatic surface advanced through the dam quickly, and that the clay core reached a nearly steady flow condition within about 8 years. It is believed that only the lower portion of the core became completely saturated during this period.

\section{Slope Stability Analyses}

Stability analyses showed that a considerable reduction in factor of safety occurred during the first few years of operation of the reservoir at San Luis Dam. During this period the factor of safety with the reservoir full decreased from about 4.0 to about 2.0 as a result of loss in strength in the slopewash when it was wetted by the 
reservoir.

During rapid drawdown the factor of safety decreased further, as a result of removal of the stabilizing external water pressures on the slope, combined with incomplete dissipation of the excess pore pressures within the dam and its foundation. The factor of safety calculated for the drawdown condition, using the fully softened peak strength within the slopewash, was about 1.35.

Only by using a strength for the slopewash close to the residual value was it possible to calculate a factor of safety equal to unity for the conditions under which failure actually occurred. Thus a critical factor leading to the occurrence of the 1981 slide is believed to be the reduction in shearing resistance resulting from the cyclic loading imposed on the slopewash as the reservoir was filled and emptied eight times during the 14 years preceding the slide.

\section{Cyclic Direct Shear Tests}

A major part of the study involved a series of cyclic direct shear tests in which the slopewash was subjected to shear stresses that simulated the rise and fall of the reservoir. The stress paths employed in these tests were determined using finite element analyses of the stresses in the embankment and the slopewash. The results of these 
cyclic loading tests showed that, as the shear stresses on the specimens were cycled between low values representing the reservoir full condition and higher values representing the reservoir empty condition, the specimens deformed continually, even though both conditions represented "safe" stress conditions in which the applied shear stresses were smaller than the peak fully softened shear strength. After 18 loading cycles in the first test, the accumulated shear displacement was about 2.0 inches.

Continuation of cyclic loading in a second test showed that additional cycles of loading produced further shear deformation. It appears likely from these results that a sufficient number of drawdown cycles would lead to accumulation of the eight to ten inches of displacement required to reduce the strength of the slopewash material to its residual value. Although the strength of the slopewash was not reduced to its residual value in seven cycles (the number of significant cycles that occurred in the field), it seems probable that the displacements would be large enough to reduce the strength to its residual value if each cycle had lasted longer, because displacement was continuing when each cycle ended.

\section{Performance and Stability of the Repaired Embankment}

Finite element analyses indicate that the movements 
observed during the 1984 drawdown resulted from a process of transferring load from the slide mass to the berm. Additional movements probably will occur during future large drawdown cycles, but the movements are expected to be smaller than those measured in 1984. Stability analyses indicate that the berm will be effective in maintaining stability of the dam during large future drawdown cycles.

\section{Implications}

On the basis of the experiments and analyses conducted during this research study, it seems highly likely that the 1981 slide at San Luis Dam was caused by two factors that lead to a very considerable loss in strength in the slopewash beneath the upstream slope:

1) Soaking by the reservoir reduced the strength of the slopewash from its very high strength in the desiccated condition to its fully softened peak value.

2) Cyclic loading due to emptying and filling of the reservoir further reduced the strength, eventually to a value very close to the residual value. After the slide began, the shear strength was reduced to the residual value as a result of the large shearing displacements that accompanied the slide. 
This finding has important implications for all slopes in clay and embankments on clay that are subjected to cyclic loading. The effects of cyclic loading on the clays should be investigated if the design condition will impose shear stresses in excess of the residual shear strength. 


\section{REF ERENCES}

1. Bjerrum, L. "Progressive Failure in Slopes of Overconsolidated Plastic Clay and Clay Shales." Journal of the Soil Mechanics and Foundations Division ASCE Vol. 93 No. SM5 (September 1967): 139-190.

2. Bureau of Reclamation. San Luis Unit, Technical Record of Design and Construction Volumes 1 and 2 . U.S. Department of Interior Government Printing office, 1974 .

3. Bureau of Reclamation, Embankment Dams Division, Denver, CO, 1981. Personal communication regarding slope indicator data and slopewash material properties.

4. Bureau of Reclamation, Embankment Dams Division, Denver, CO, 1983. Personal communication regarding permeability and stress-strain parameters for the embankment materials.

5. Bureau of Reclamation, Embankment Dams Division, Denver, CO, Knodel, P. 1986. Personal communication regarding Atterberg limits, shear strength parameters and consolidation characteristics from Bureau of Reclamation testing.

6. Bureau of Reclamation, Embankment Dams Division, Denver, CO, Morfitt, B., Design and Analysis of Stability Berm. Bureau of Reclamation Technical Memorandum No. SL-II-222-4, March, 1982.

7. Bureau of Reclamation, Embankment Dams Division, Denver, Co, Morfitt, B., Pore Pressure Assumptions for Analysis of San Luis Dam Slide. Bureau of Reclamation Technical Memorandum No. SL-II-222-3, August, 1984.

8. Bureau of Reclamation, Embankment Dams Division, Denver, CO, Morfitt, B., 1985. Personal communication regarding stress-strain parameters for the embankment materials and foundation and embankment permeabilities from Bureau of Reclamation files. 
9. Bureau of Reclamation, Embankment Dams Division, Denver, CO, Von Thun, L., R. Ballard and B. Morfitt, Back Analysis of San Luis Slide with Additional Attention to the Slopewash Surface and the Deformed Sections. Bureau of Reclamation Technical Memorandum No. SL-II- 230-1, September, 1981.

10. Bureau of Reclamation, Embankment Dams Division, Denver, CO, Von Thun, L., Back Analysis of San Luis slide with Additional Attention to the Slopewash Surface and the Deformed sections. Bureau of Reclamation Technical Memorandum No. SL-II-232-2, 1984.

11. Bureau of Reclamation, Embankment Dams Division, Denver, CO, Von Thun, L., Accountability Report - San Luis Dam Rehabilitation, Reply to Consultants Responses. Memorandum No. D-230, 1984 .

12. Bureau of Reclamation, Embankment Dams Division, Denver, CO, Von Thun, L. Evaluation of the 1984 Movements Associated with the 1982 San Luis Dam Rehabilitation. Bureau of Reclamation Technical Memorandum No. SL-II-230-5, April, 1985.

13. Department of Water Resources Civil Maintenance Branch, Sacramento, CA, 1983. Personal communication regarding piezometer data at Station $135+00$ in San Luis Dam.

14. Department of Water Resources Civil Maintenance Branch, Sacramento, CA, 1984 and 1985. Personal communication regarding 1984 movements in San Luis Dam.

15. Delage, P. and G. Lefebvre. "Study of the structure of a Sensitive Clay and of Its Evolution During Consolidation." Canadian Geotechnical Journal Vol. 21 No. 1 (1984): 21-35.

16. Duncan, J. M., P. Byrne, R. S. Wong and P. Mabry. Strength, Stress-strain and Bulk Modulus Parameters for Finite Element Analysis of Stresses and Movements in Soil Masses. Report No. UCB/GT/80-01: University of California, Berkeley, August, 1980.

17. Duncan, J. M., R. B. Seed, K. S. Wong and Y. Ozawa. FEADAM: A Computer Program for Finite Element Analysis of Dams. Research Report No. SU/GT/84-03: Stanford University, November, 1984. 
18. Duncan, J. M., R. W. Fleming and F. D. Patton, 1986. Report of the Thistle slide Committee to state of Utah Department of Natural Resources Division of Water Rights. USGS Open File Report 86-505.

19. Duncan, J. M. 1986. Personal communication regarding build-up analysis.

20. Lambe, T. William. Soil Testing for Engineers. New York: John Wiley and Sons, Inc., 1951.

21. Mitchell, James R., Don R. Hooper and Richard G. Campanella. "Permeability of Compacted Clay." Journal of the Soil Mechanics and Foundations Division ASCE Vol. 91 No. SM4 (July 1965): 41-65.

22. Olson, Roy E. and Leonard J. Langfelder. "Pore Water Pressures in Unsaturated Soils." Journal of the Soil Mechanics and Foundations Division ASCE Vol. 91 No. SM 4 (July 1965) : 127-150.

23. Skempton, A. W. "Long-term Stability of Clay Slopes." Geotechnique 14 No. 2 (1964): 75-101.

24. Skempton, A. W. and J. N. Hutchinson. "Stability of Natural Slopes." Proc. 7th ICSMFE, Mexico City, State of the Art Volume (1969): 291-340.

25. Skempton A. W. "First-time Slides in Overconsolidated Clays." Geotechnique 20 (1970): 320-324.

26. Skempton, A. W. "Slope Stability of Cuttings in London Clay." Ninth ICSMFE, Tokyo Special Lecture Volume (1977): 261-270.

27. Skempton, A. W. "Residual Strength of Clays in Landslides, Folded Strata and the Laboratory." Geotechnique 35 No. 1 (1985): 3-18.

28. Spencer, E. "A Method of Analysis of the Stability of Embankments Assuming Parallel Inter-slice Forces." Geotechnique 17 (1967): 11-26.

29. Wright, S. G. and J. M. Duncan. "The Accuracy of Equilibrium Methods of slope Stability Analysis." International Symposium on Landslides New Dehli $(1980): 247-254$. 
APPENDIX A

San Luis Dam - Facts and Figures

221 


\section{APPENDIX A - San Luis Dam - Facts and Figures}

\section{Background}

Location: 100 miles southeast of San Francisco, California

Designed by: Bureau of Reclamation

Built by: Joint venture of Morrison-Rnudsen Co., Inc., Utah Construction and Mining, and Brown and Root, Inc.

Ownership: 558 State, 458 Federal

Construction dates: Began in 1963, completed in 1967

Type of construction: Earth and rockfill dam

\section{Dimensions}

Maximum height: 385 feet

Height in slide area: 200 feet; dam is founded on an existing hill

Crest length: 3.5 miles

Volume of fill: 78 million cubic yards

\section{Reservior}

Capacity: 2.1 million acre-feet

Maximum depth: 304 feet

Average drawdown: 1,036,000 acre feet/year (1979-1986)

Cost of water: $\$ 100$ per acre-foot

Average annual water revenue: 104 million dollars 


\section{Importance}

San Luis Reservoir, the largest off-stream reservoir in the United States, stores water for the California State Water Project and the Federal Central Valley Project. Water is pumped into San Luis Reservoir from the Sacramento-San Joaquin River Delta, primarily during the winter and spring when surplus water from runoff and snowmelt flows through the delta.' When the delta flow does not have enough surplus to supply the two water projects, water is released from the reservoir into the California Aqueduct system. Large agriculture and water revenues make it imperative that San Luis Dam remains operational.

\section{Upstream Slide}

Movement began: September 14, 1981

Location of maximum movement: Station $135+00$

Movement ended: January, 1982

Final scarp length: 1700 feet

Final slide volume: 1.3 million cubic yards

1981 drawdown: 180 feet at 1.5 feet/day (largest and fastest in reservoir history) No water released from reservoir due to the large drawdown 


\section{Repair}

San Luis Dam was successfully repaired by late March, 1982 using a 60 foot high rockfill stabilizing berm. The construction schedule was to have the berm completed up to an elevation of 415 feet, approximately 45 feet high, by April 1, 1982 and finished to elevation 430 feet after the summer drawdown lowered the reservoir again. Having the berm up to elevation 415 feet by April 1, 1982 would enable about 600,000 acre-feet of water to be stored in the reservoir during the spring runoff. This quantity, combined with water borrowed from the Metropolitan Water District of Southern California, would be enough to meet 95-1008 of the 1982 summer commitments. The April 1 date was critical because most of the winter runoff has passed through the delta by May 1 .

Peter Riewit and Sons was awarded two contracts totaling 8.5 million dollars in December, 1981 with a performance clause to have the berm up to elevation 415 feet by April 1, 1982. The performance clause awarded Kiewit $\$ 20,000$ per day up to $\$ 100,000$ for meeting this goal before April 1. Similarly, the contract penalized Riewit $\$ 20,000$ per day up to $\$ 100,000$ for not meeting the deadline.

With this incentive the contractor worked six day, 100 hour weeks from late December to mid-March when the berm 
was completed to elevation 430 feet, 15 feet higher than required, and two months ahead of schedule. In all, 1.4 million cubic yards of select material was placed during this period and allowed an additional 125,000 acre-feet of water to be stored which prevented any major water shortages during the 1982 summer. Peter Riewit and Sons received the $\$ 100,000$ bonus and the dam has been in continuous operation ever since. 
APPENDIX B

Results of Laboratory Consolidation Tests 


\section{APPENDIX B - Results of Laboratory Consolidation Tests}

Twelve consolidation tests, nine using undisturbed test specimens, were performed on the upstream slopewash material. Tables 3-2 and 3-3 provide summaries of the consolidation tests on upstream block samples $36 \mathrm{~F}-1101$ and $36 \mathrm{~F}-1102$, respectively.

Nine consolidation tests, four using undisturbed test specimens, were performed on the downstream slopewash material. Tables 3-4 and 3-5 provide summaries of the consolidation tests on downstream block samples $36 \mathrm{~F}-1103$ and $36 \mathrm{~F}-765$, respectively.

All test specimens were 2.50 inches in diameter and had an initial thickness of one inch. The consolidation tests were performed using Soiltest consolidation frames and consolidometers. The consolidation pressures were applied using dead weights and the axial volume change was measured using a dial gage. 


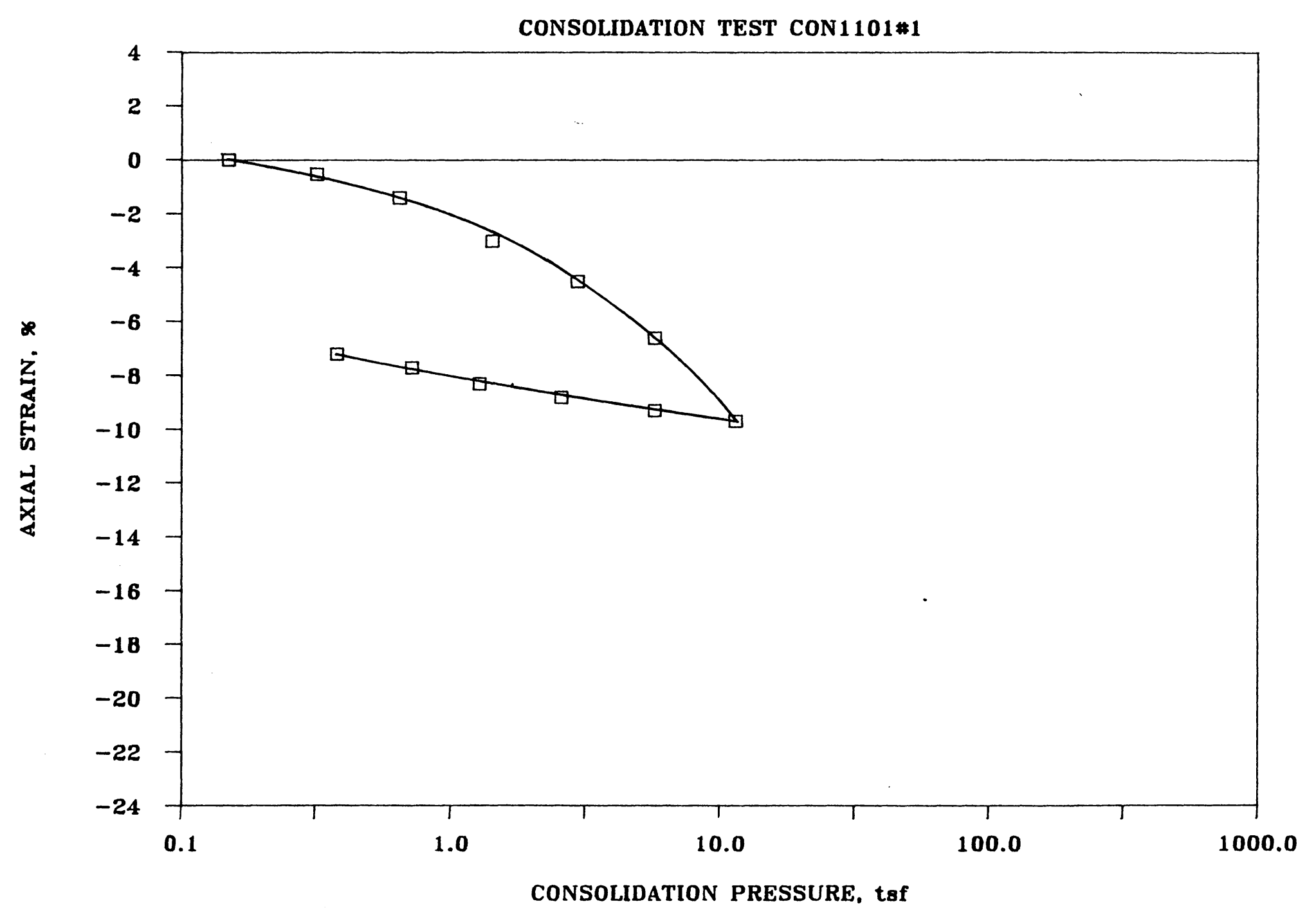

Figure B-1 Consolidation Test CON1101\#1 on Upstream Slopewash 


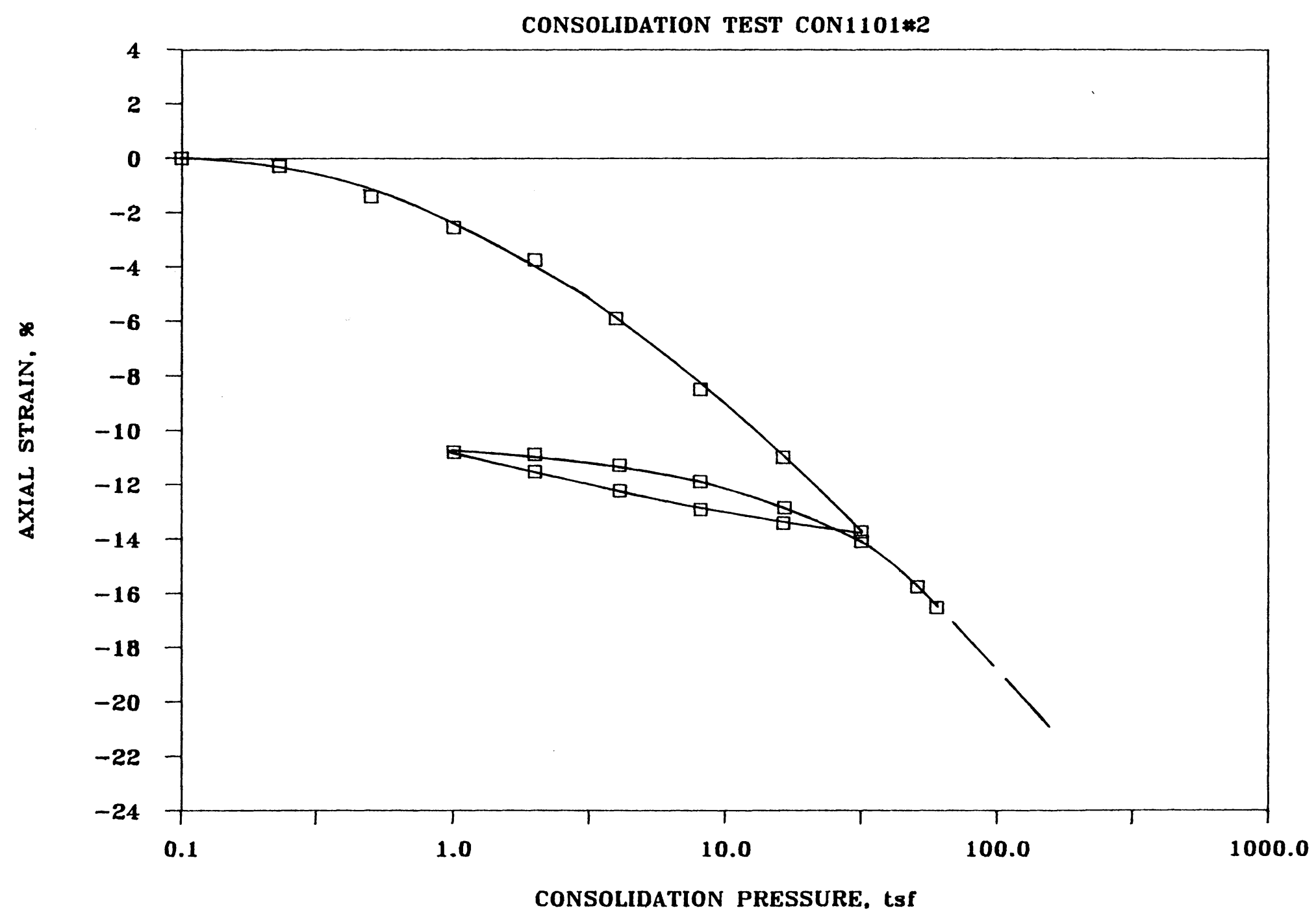

Figure B-2 Consolidation Test CON1101\#2 on Upstream Slopewash 


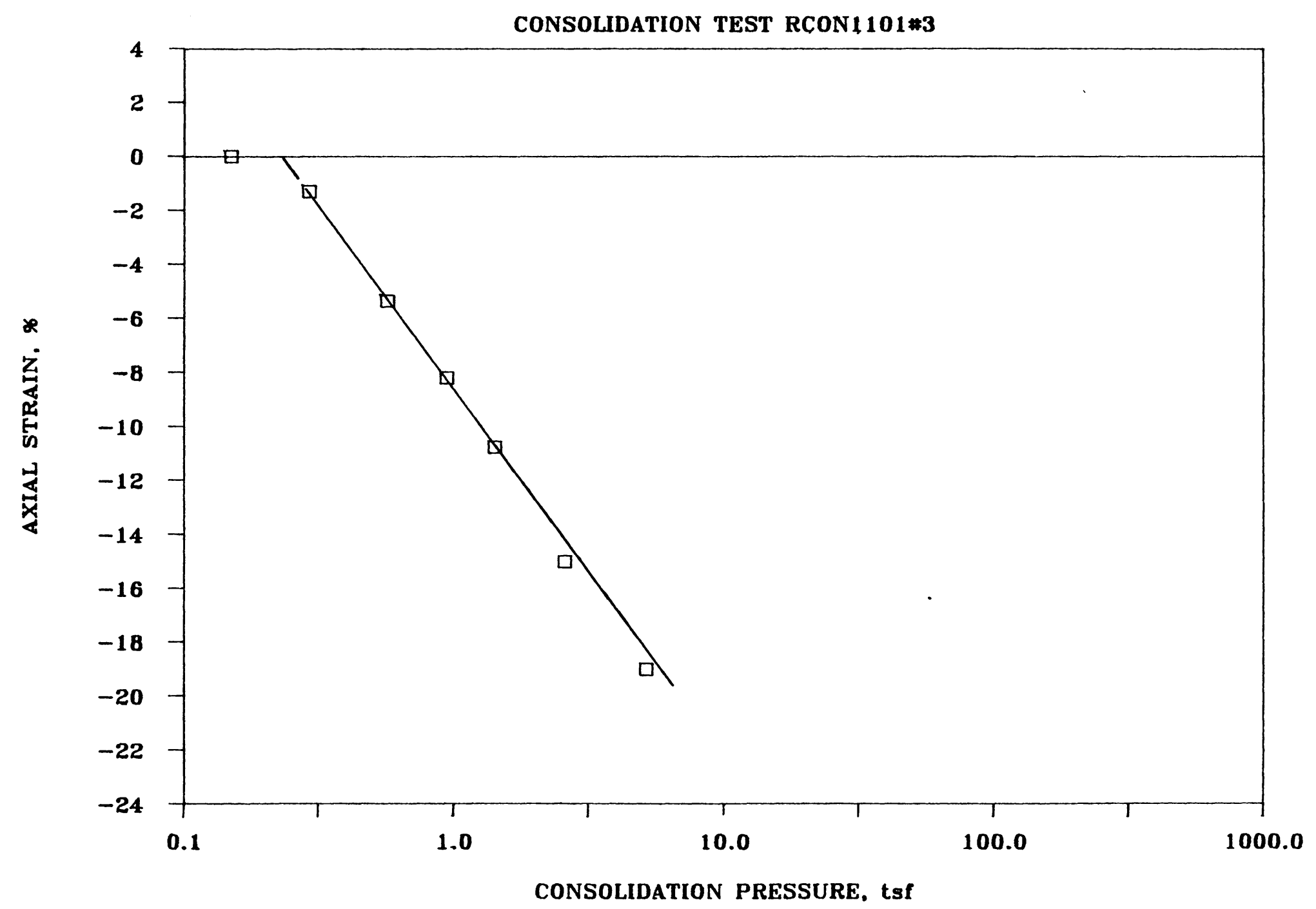

Figure B-3 Consolidation Test RCON1101\#3 on Upstream Slopewash 


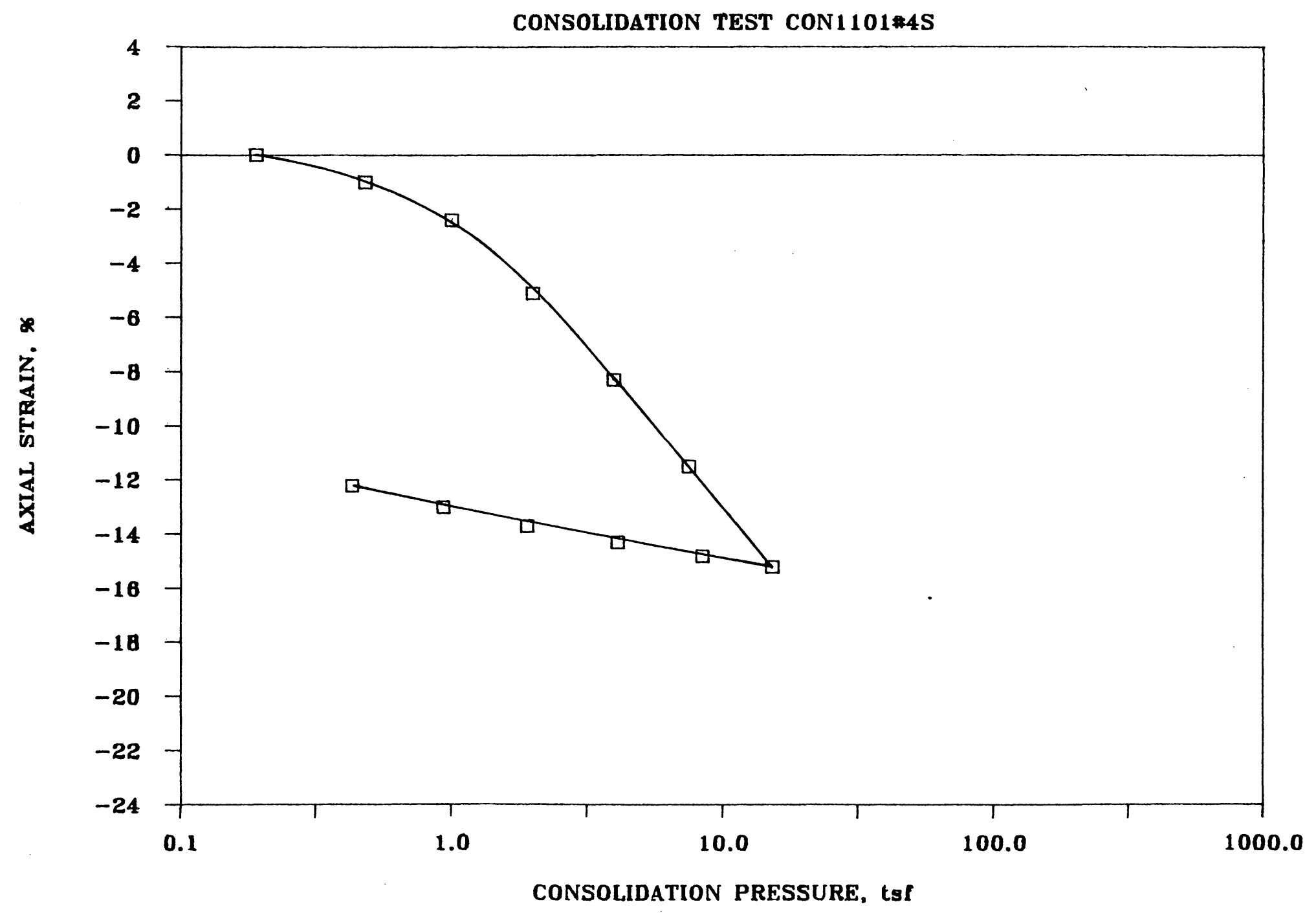

Figure B-4 Consolidation Test CON1101\#4S on Upstream Slopewash 


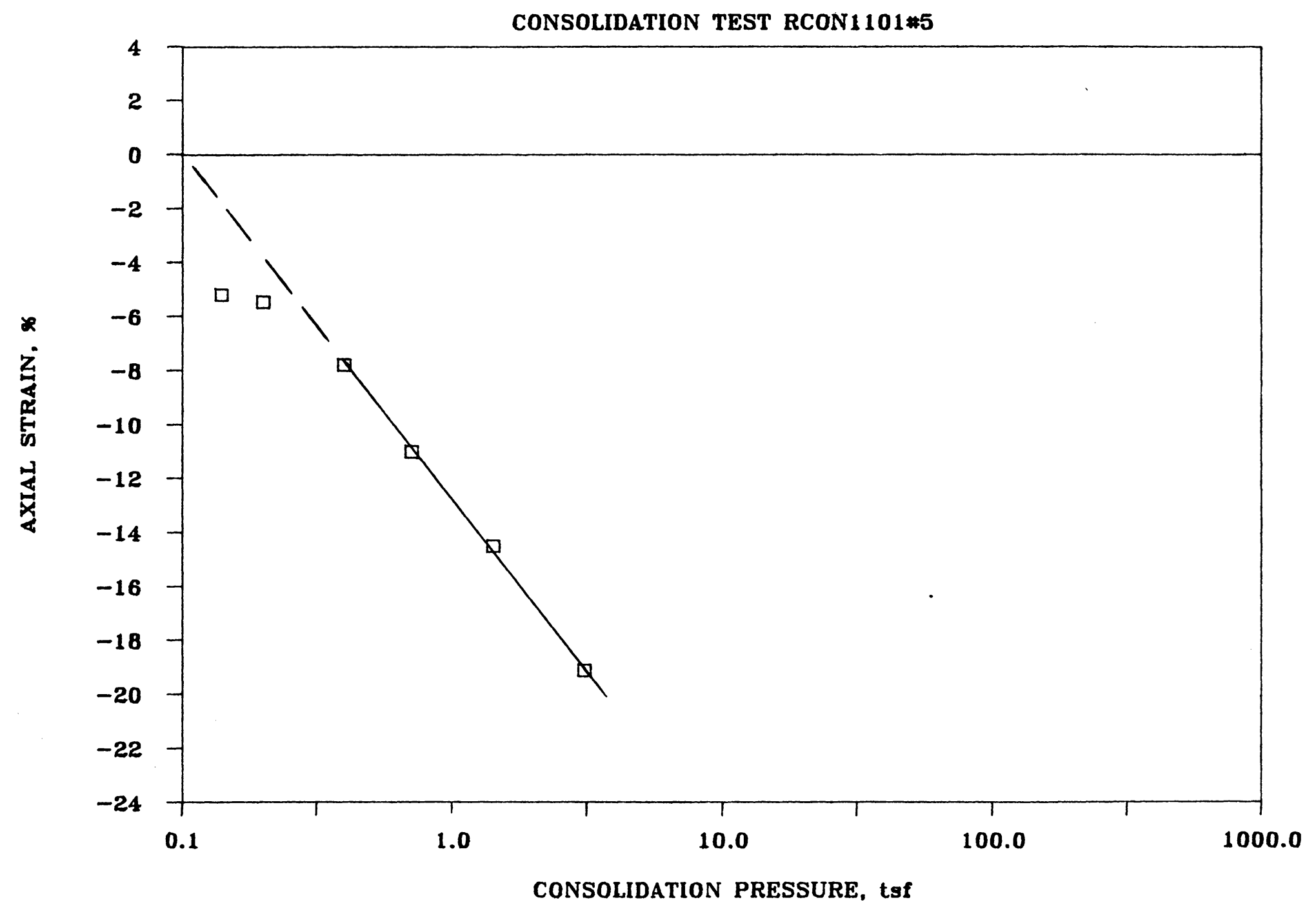

Figure B-5 Consolidation Test RCON1101\#5 on Upstream Slopewash 


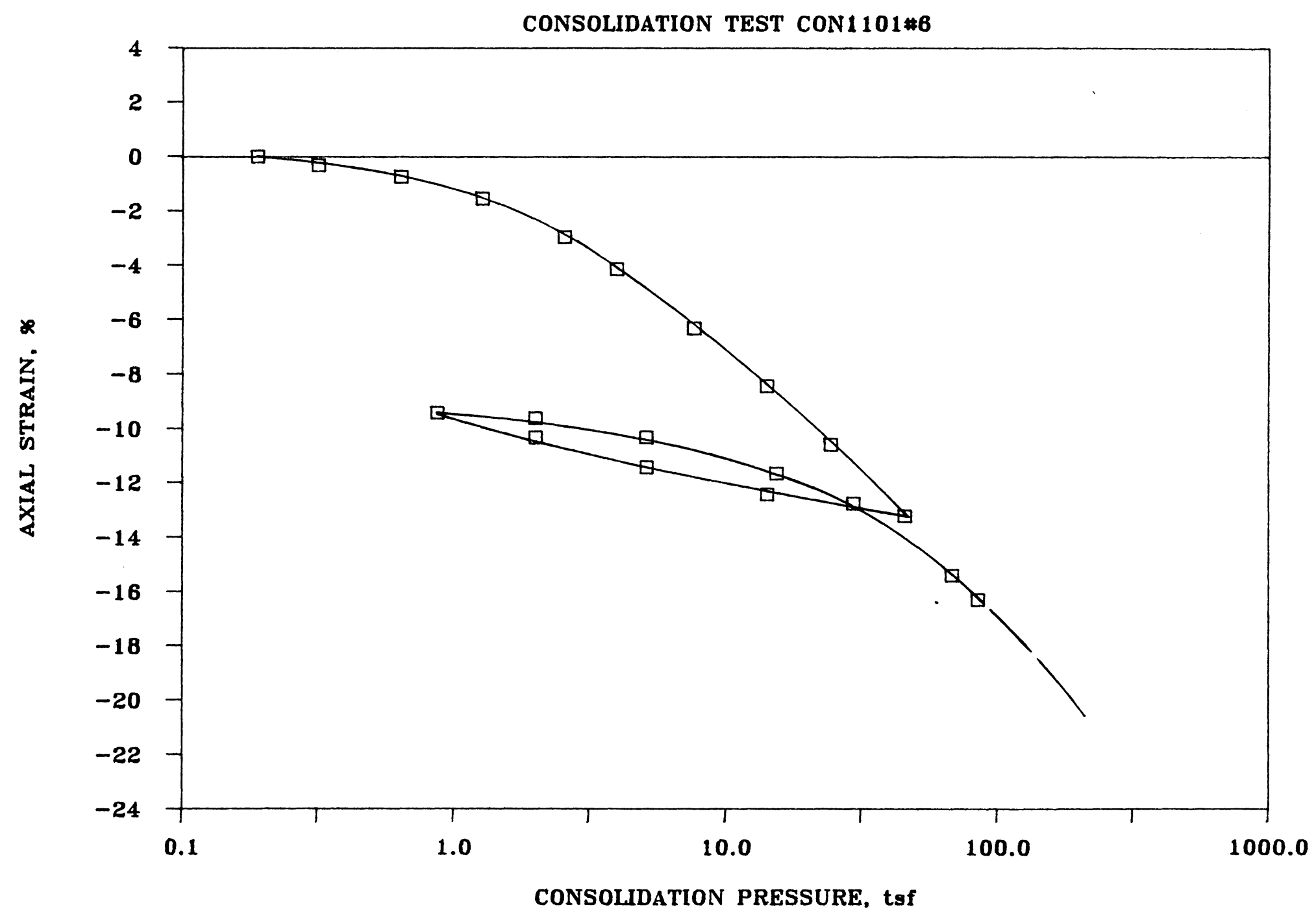

$\underset{\omega}{\tilde{\omega}}$

Figure B-6 Consolidation Test CON1101\#6 on Upstream Slopewash 


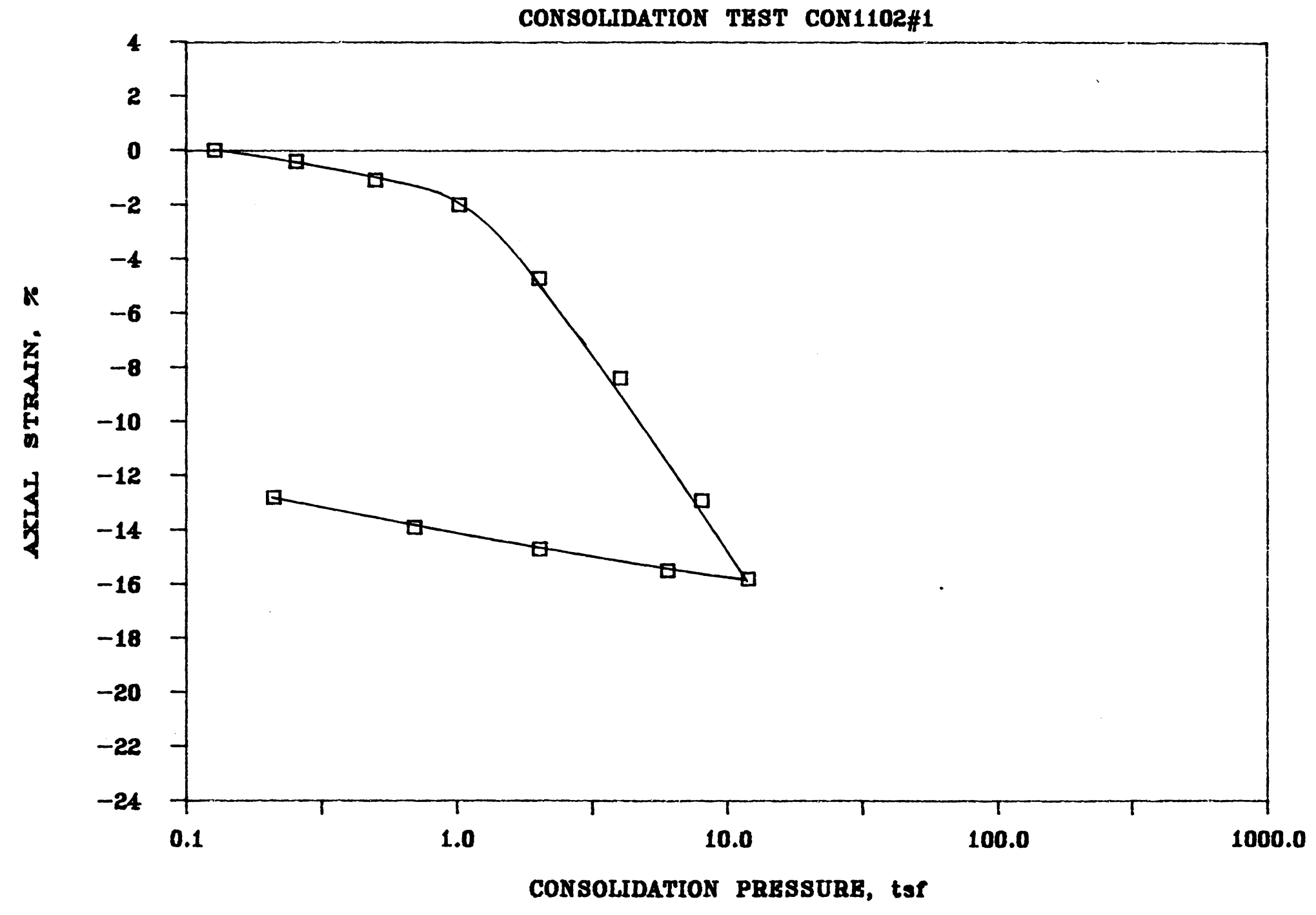

Figure B-7 Consolidation Test CON1102\#1 on Upstream Slopewash 


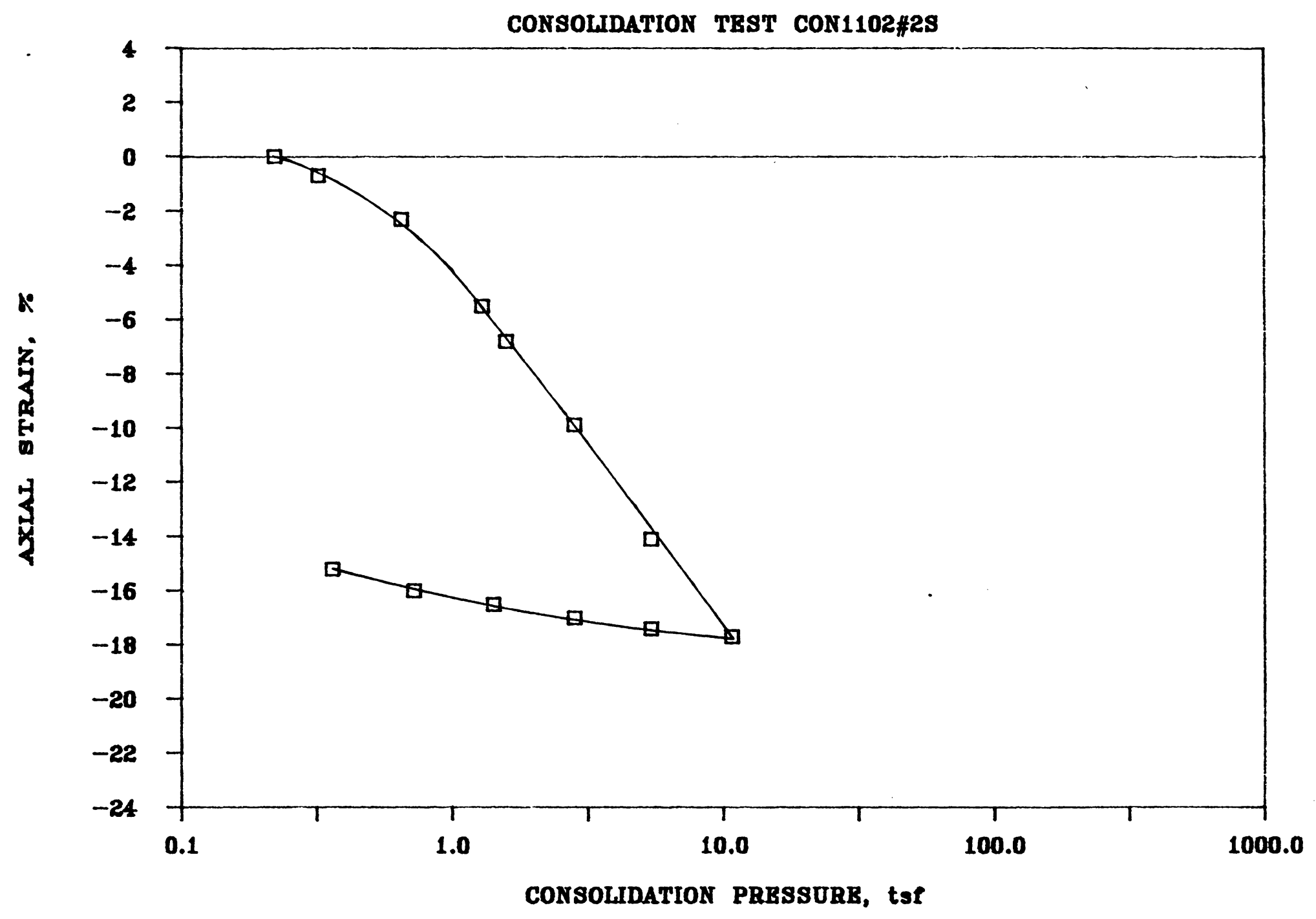

Figure B-8 Consolidation Test CON1102\#2S on Upstream Slopewash 


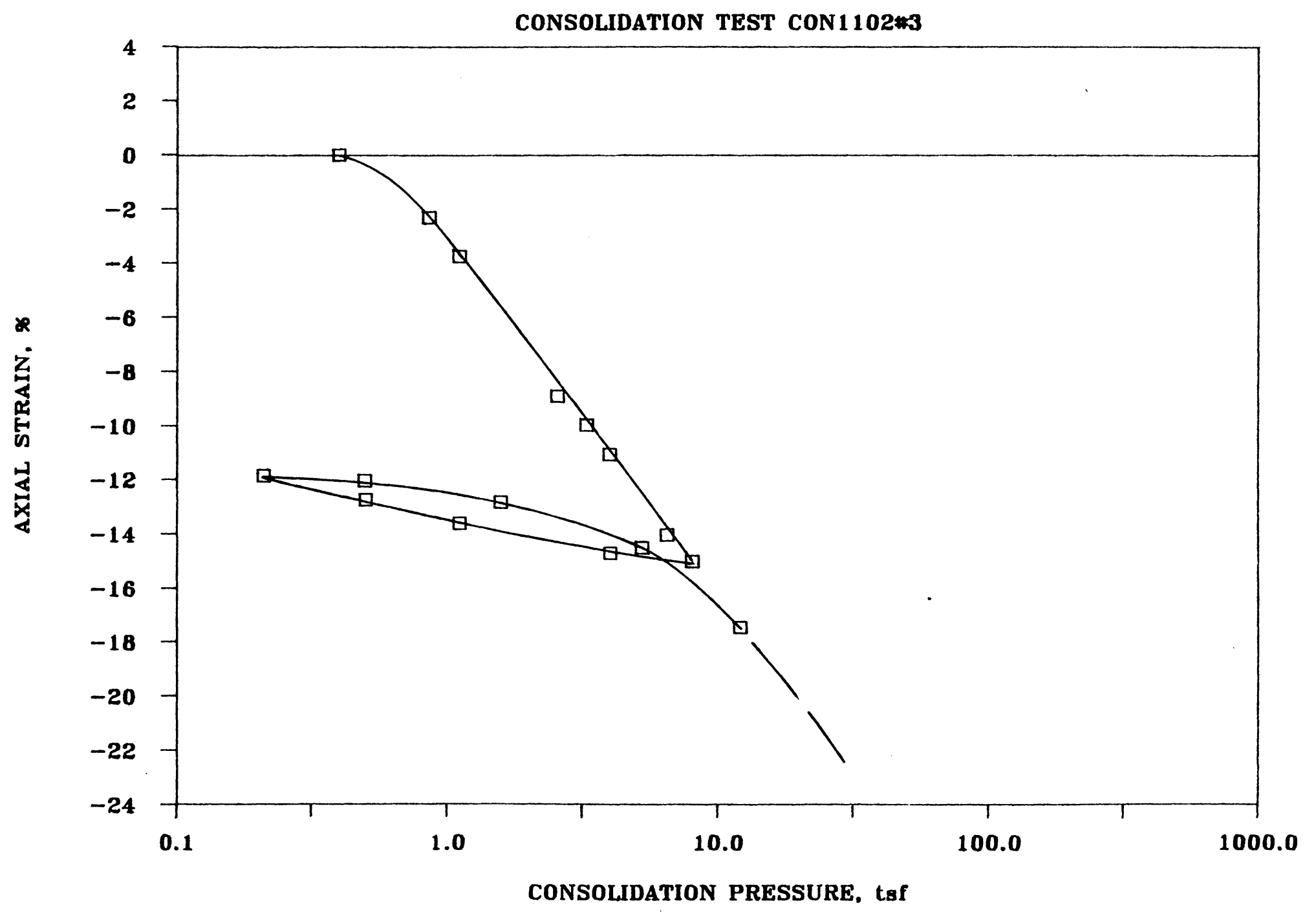

Figure B-9 Consolidation Test CON1102\#3 on Upstream Slopewash 


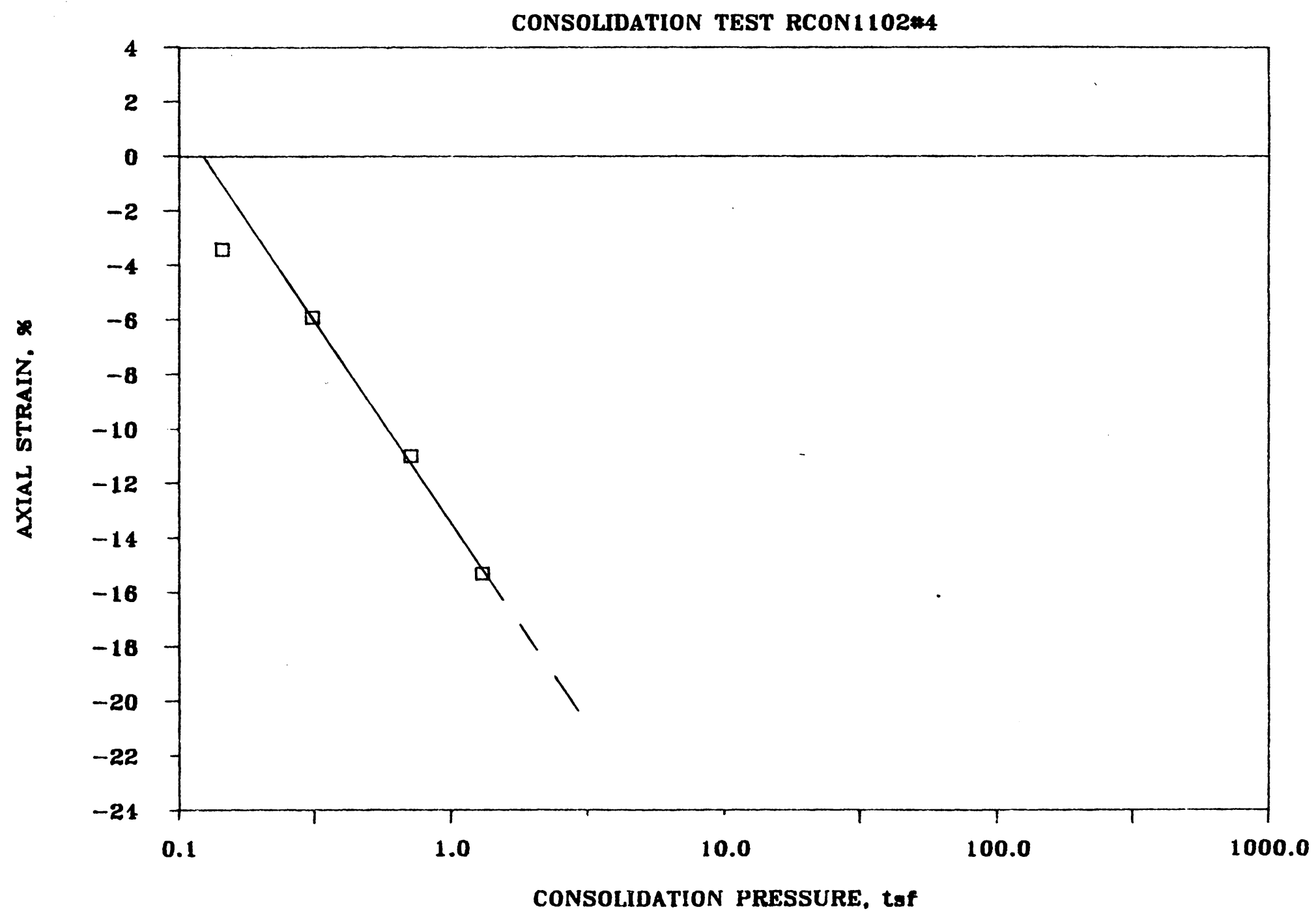

Figure B-10 Consolidation Test RCON1102\#4 on Upstream Slopewash 


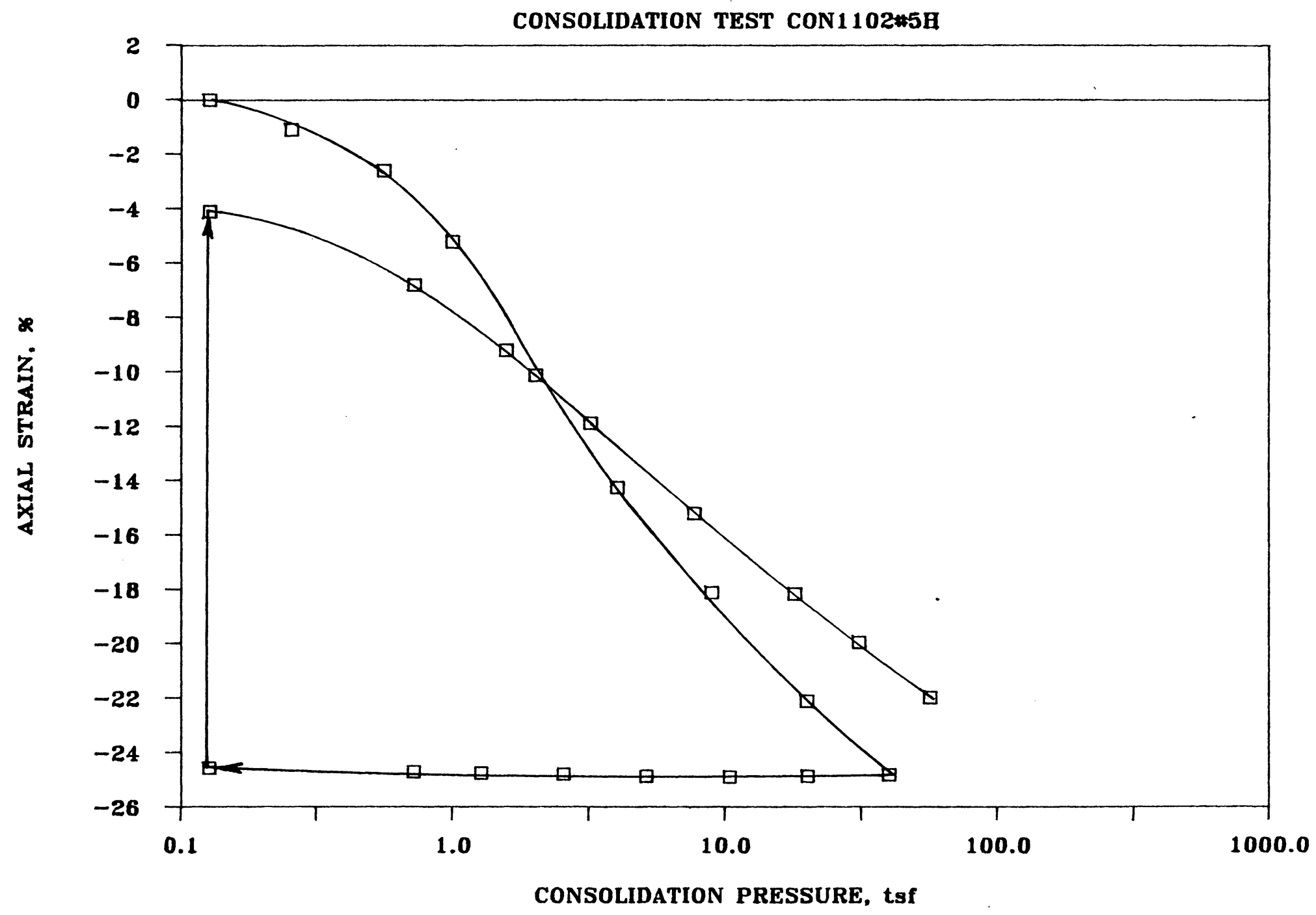

Figure B-11 Consolidation Test CON1102\#5H on Upstream Slopewash 


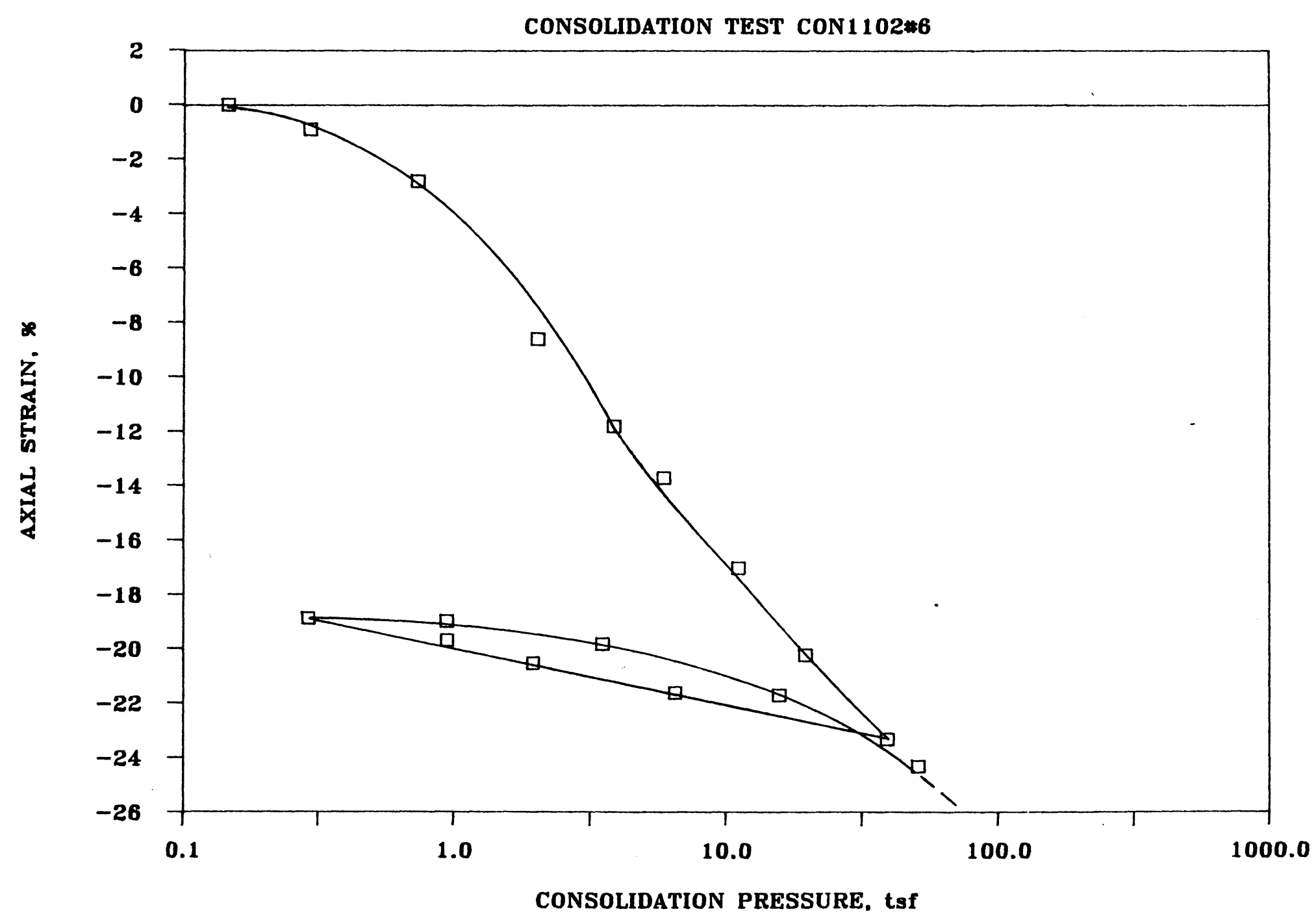




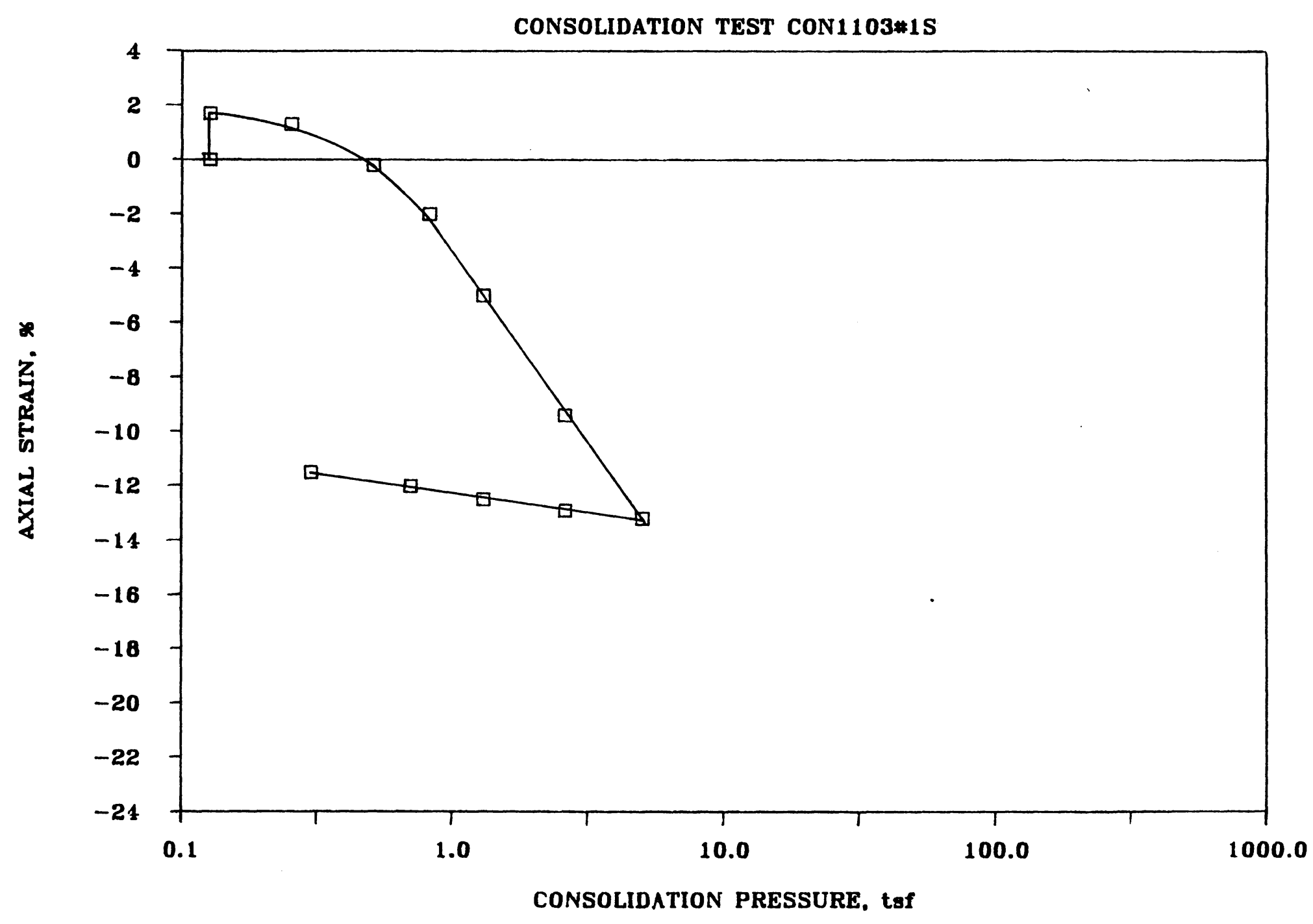

Figure B-13 Consolidation Test CON1103\#1S on Downstream Slopewash 


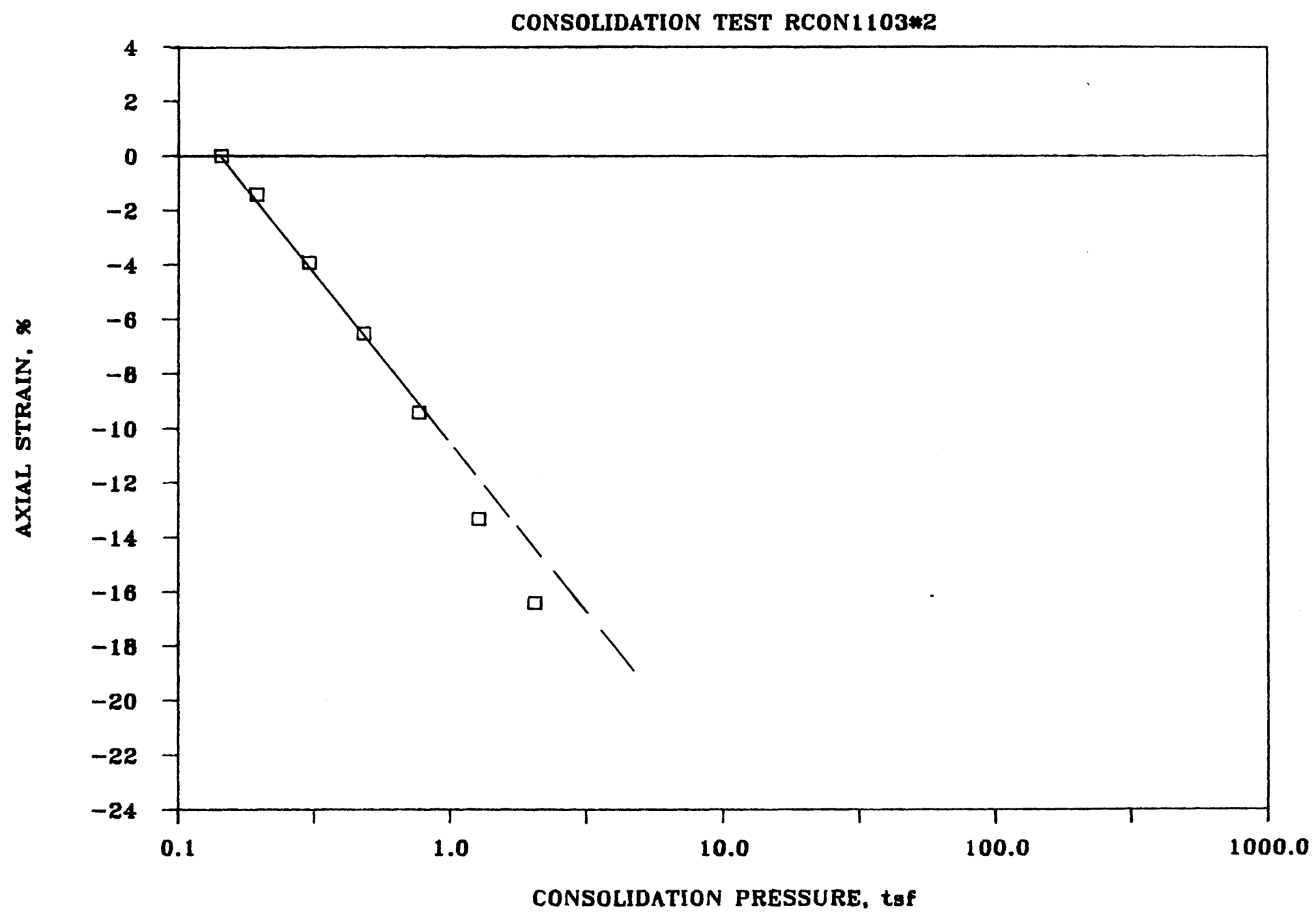

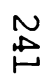

Figure B-14 Consolidation Test RCON1103\#2 on Downstream Slopewash 


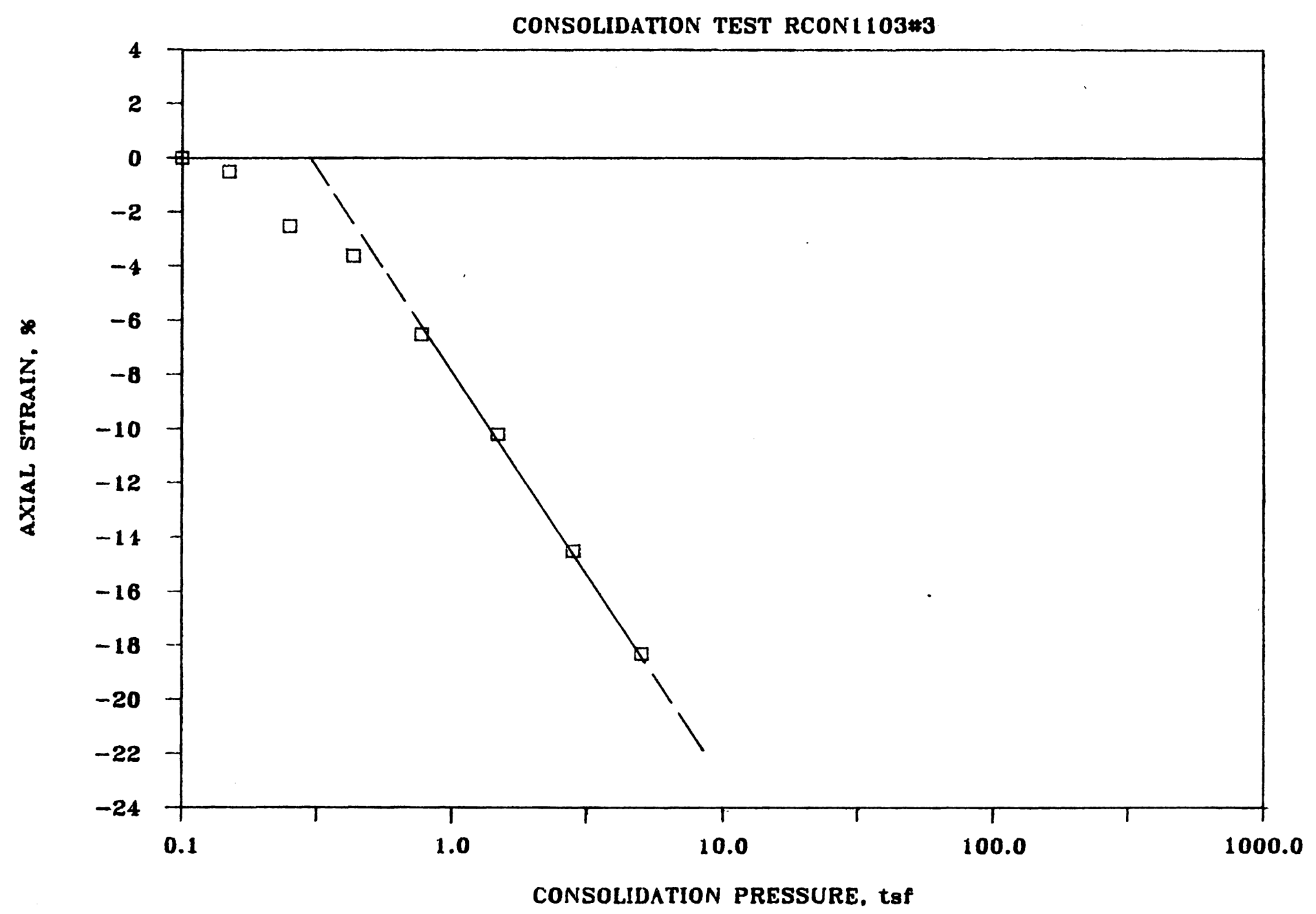

Figure B-15 Consolidation Test RCON1103\#3 on Downstream Slopewash 


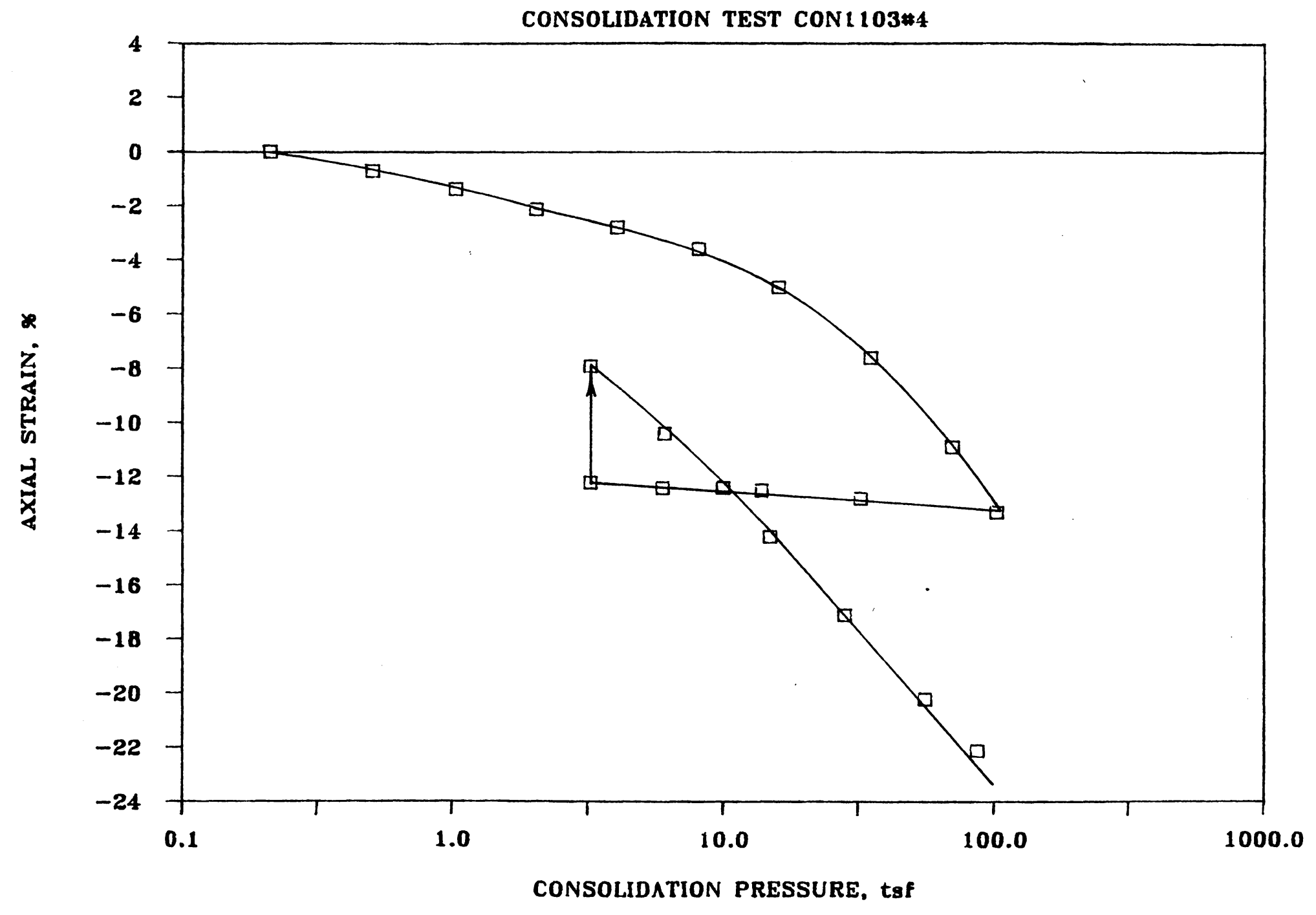

Figure B-16 Consolidation Test CON1103\#4 on Downstream Slopewash 


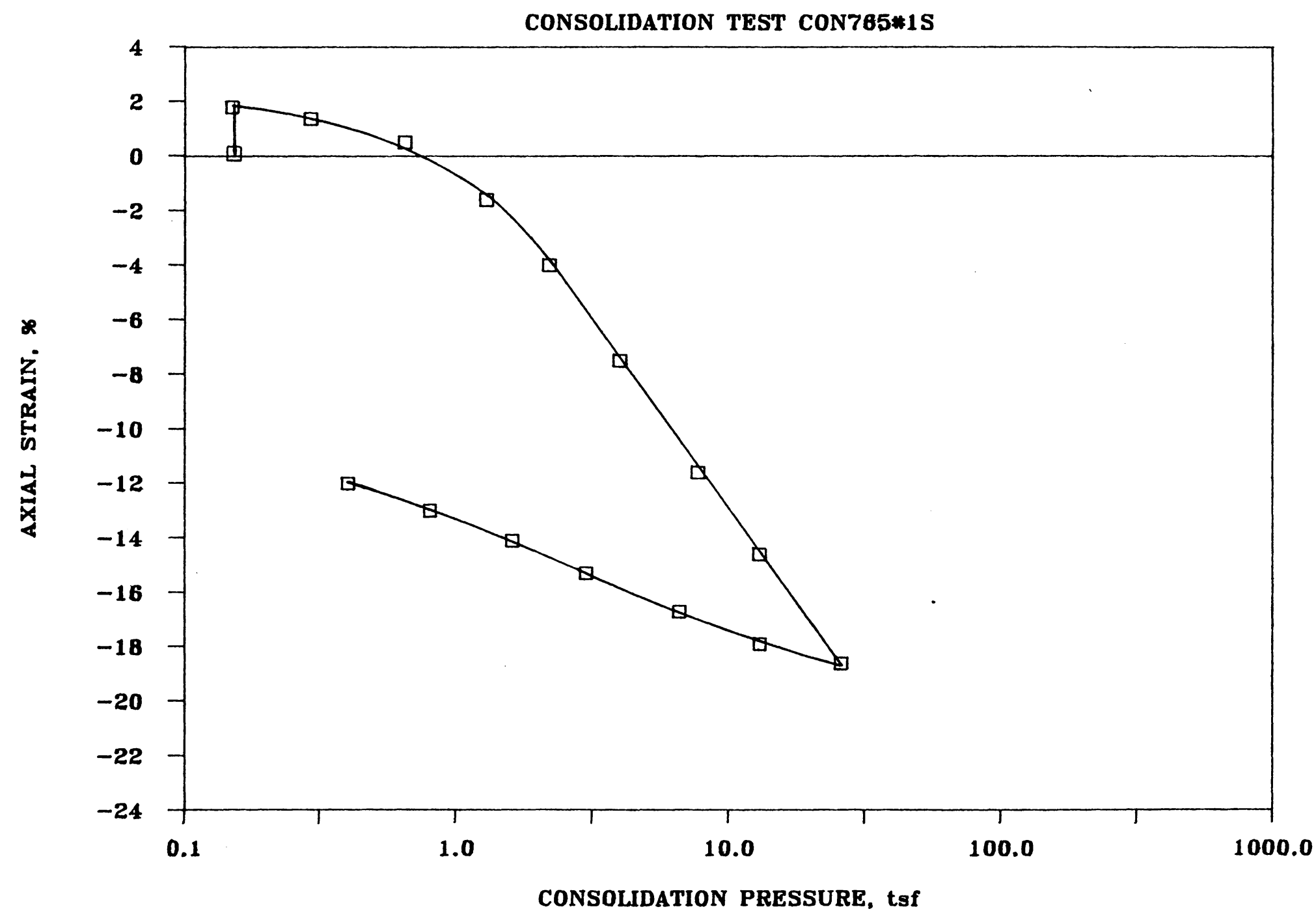

Figure B-17 Consolidation Test CON765\#1S on Downstream Slopewash 


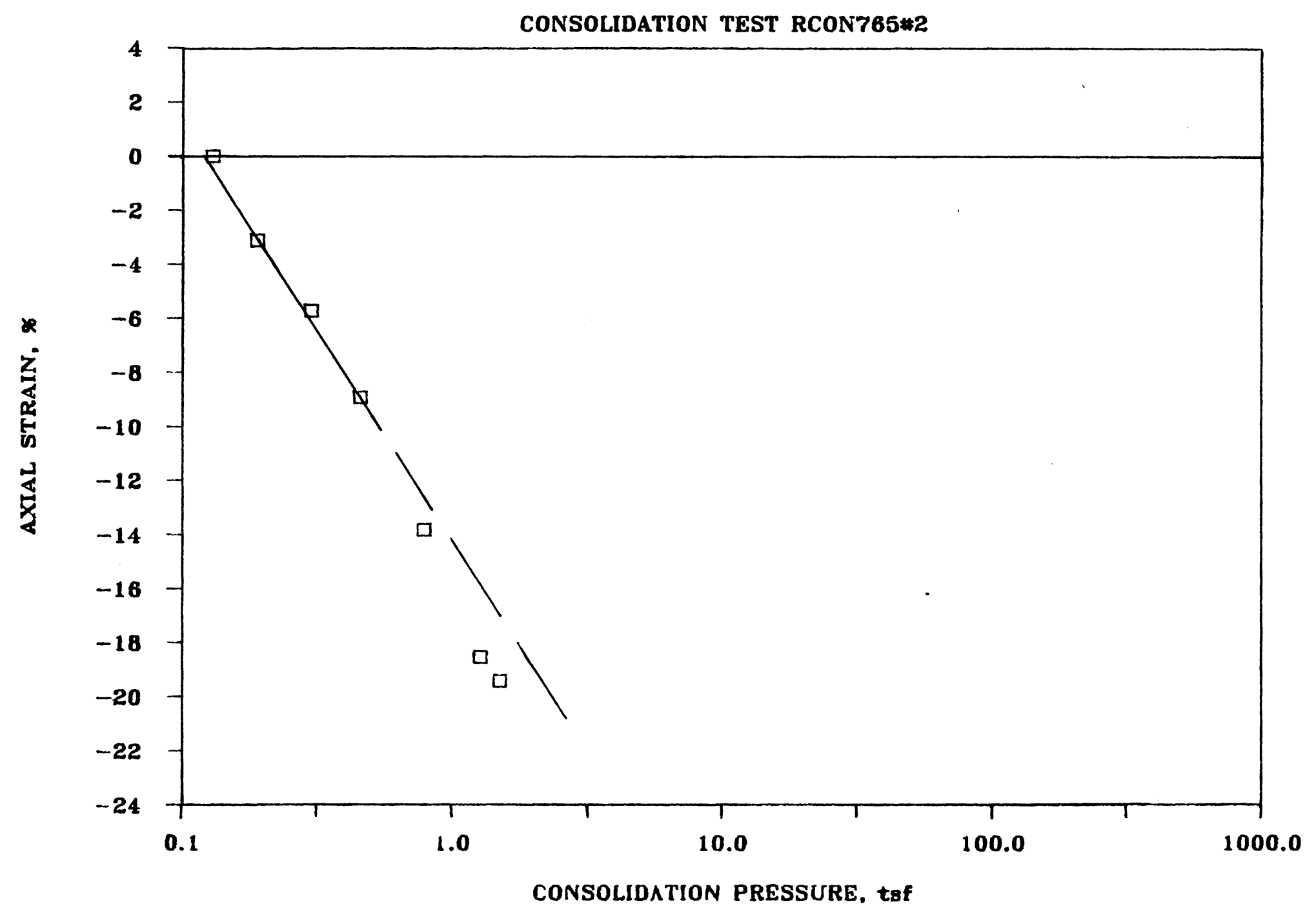

Figure B-18 Consolidation Test RCON765\#2 on Downstream Slopewash 


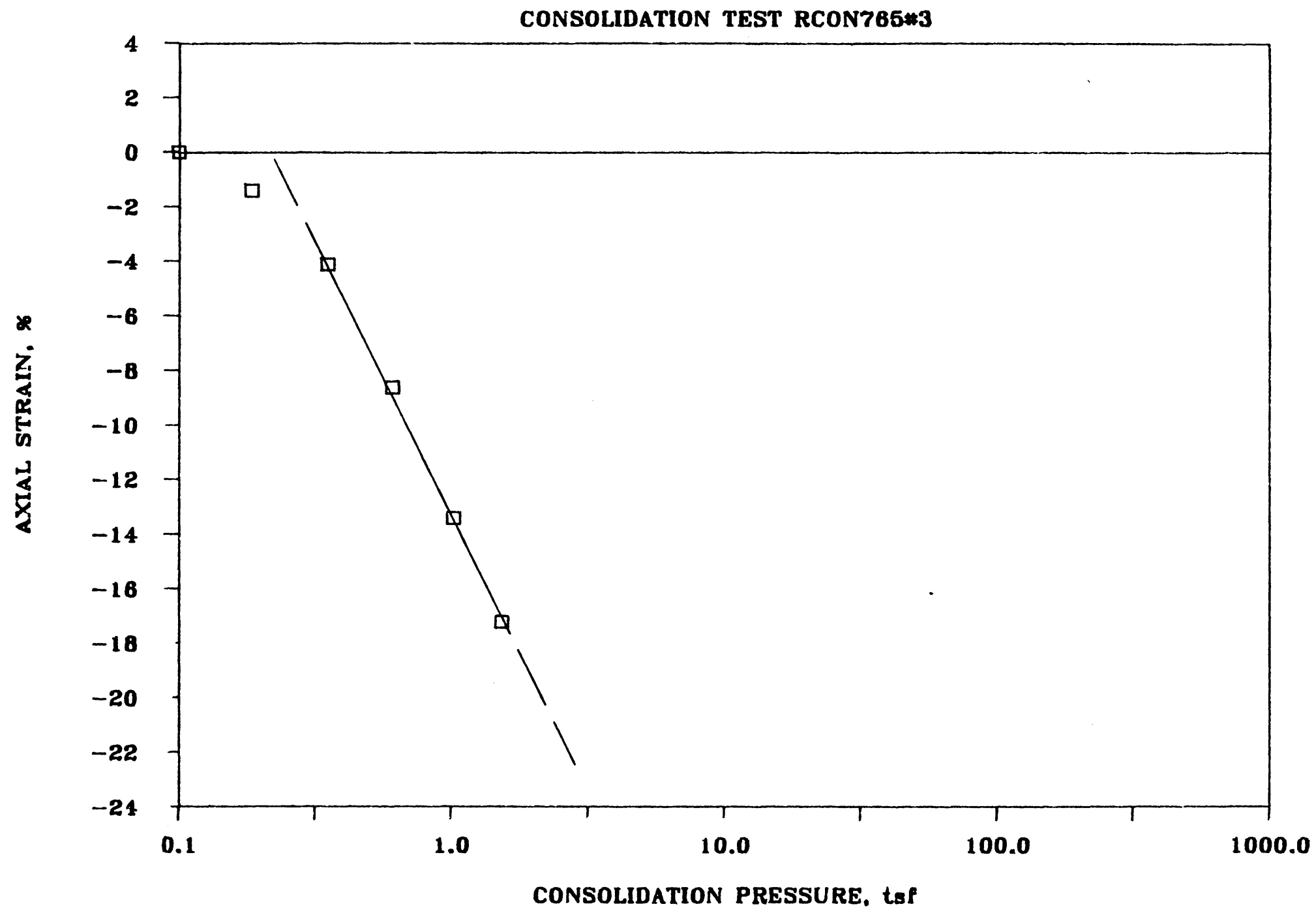

Figure B-19 Consolidation Test RCON765\#3 on Downstream Slopewash 


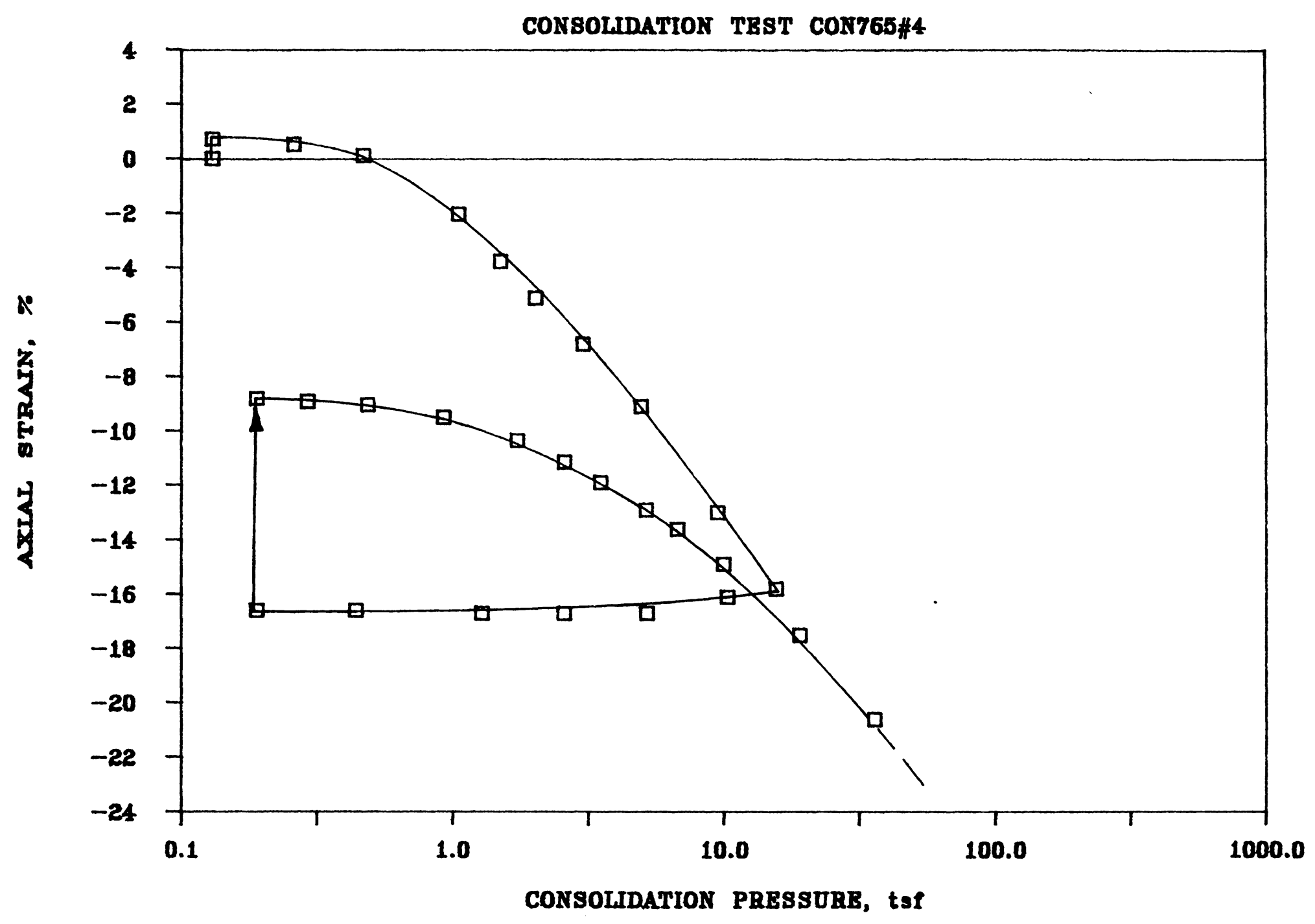

Figure B-20 Consolidation Test CON765\#4 on Downstream Slopewash 


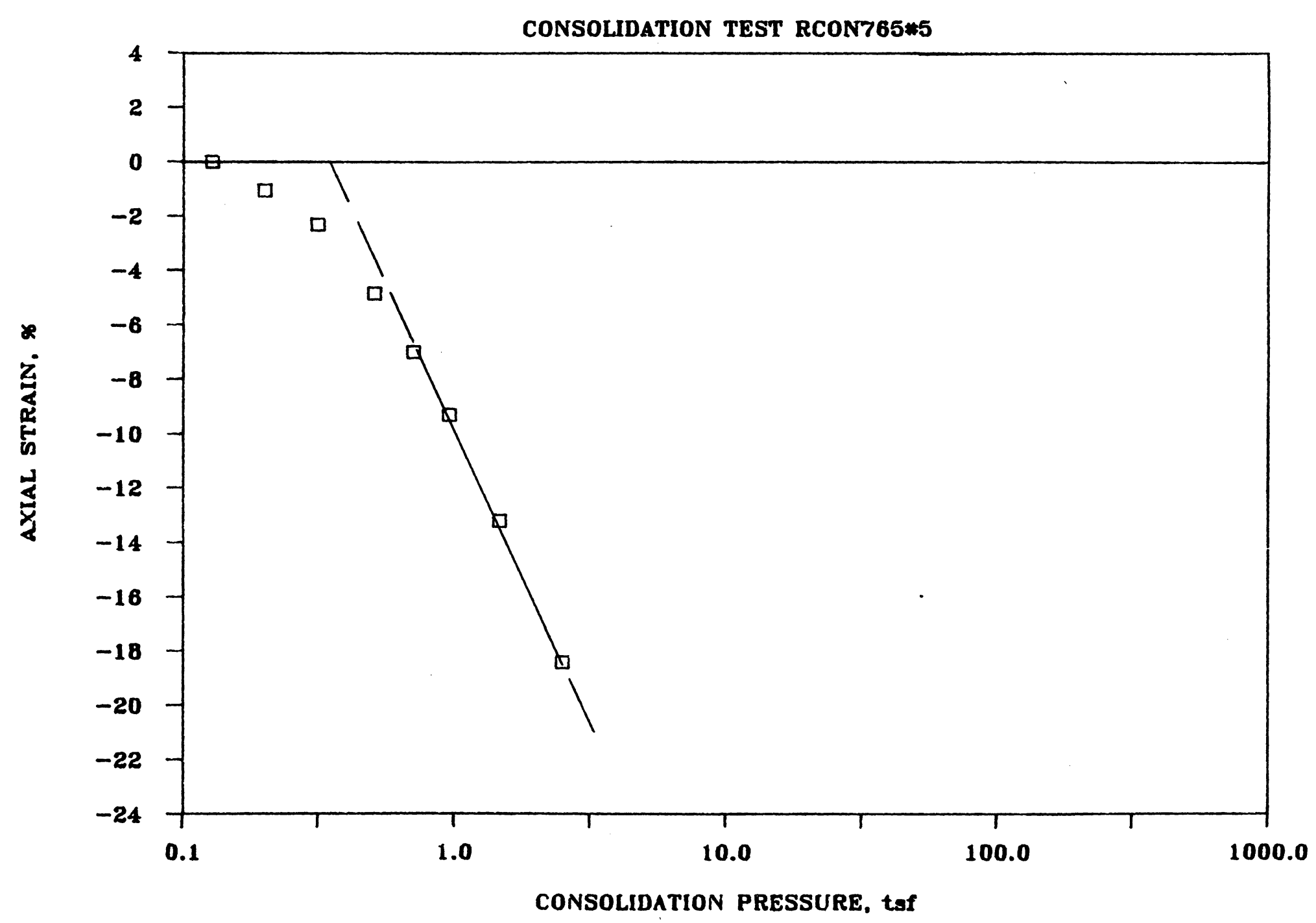

Figure B-21 Consolidation Test RCON765\#5 on Downstream Slopewash 
APPENDIX C

Results of Laboratory Direct Shear Tests 


\section{APPENDIX C - Results of Laboratory Direct Shear Tests}

Fifteen drained direct shear tests, six using undisturbed test specimens, were conducted on the downstream slopewash material. Tables 3-6 and 3-10 provide summaries of the direct shear tests on downstream block samples 36F-1103 and 36F-765, respectively.

Eighteen drained direct shear tests, seven using undisturbed test specimens, were conducted on the upstream slopewash material. Tables 3-7 and 3-8 provide summaries of the direct shear tests on upstream block samples 36F1101 and $36 \mathrm{~F}-1102$, respectively.

All test specimens were four inches square and had an initial thickness of approximately 0.8 inches. The direct shear tests were performed using a motorized Wykeham Farrance apparatus and the procedure described by Lambe (1951). The horizontal and vertical displacements were measured using dial gages and the horizontal force was measured with a load cell. The test specimens were consolidated using dead weights. 


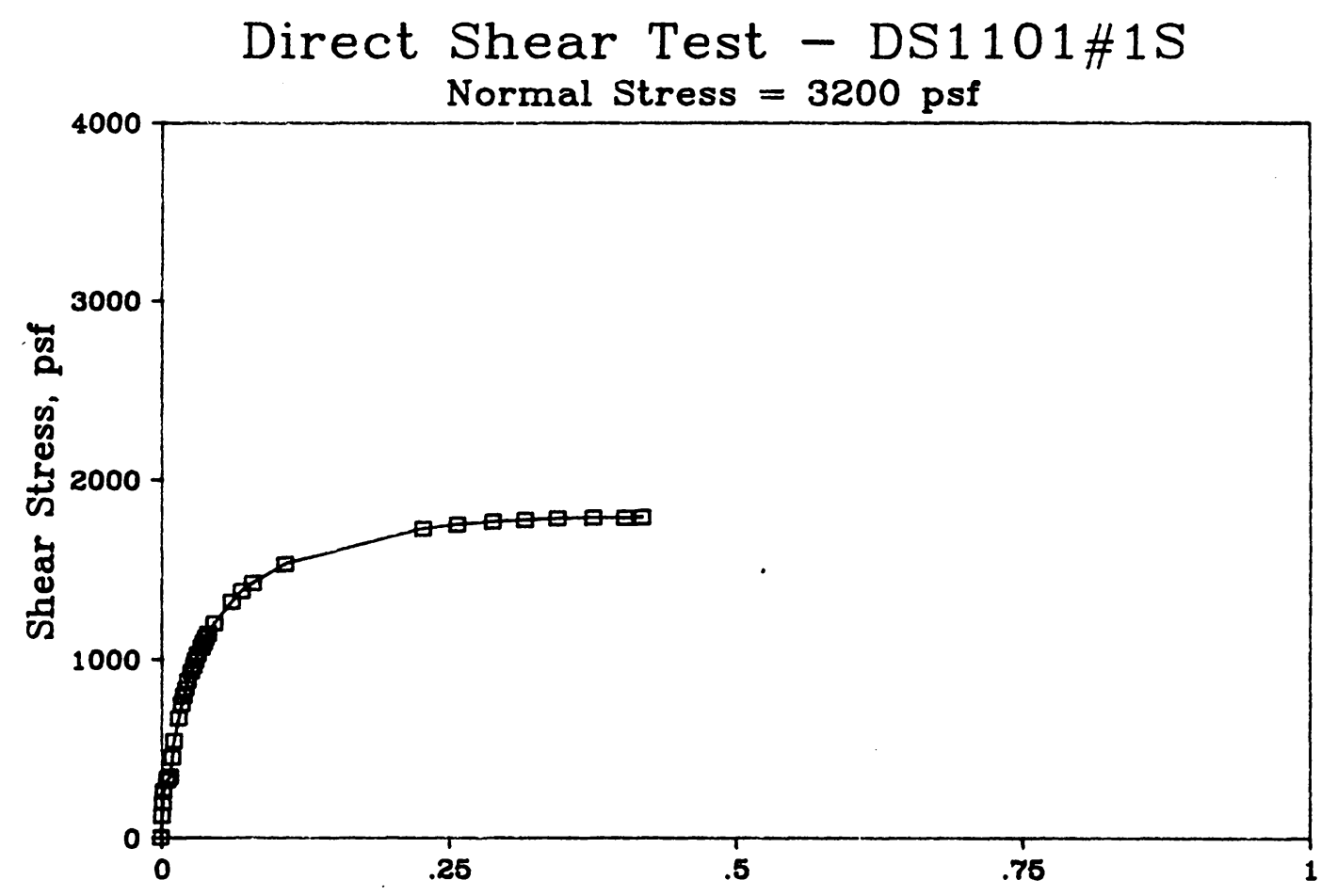

Horiz. Displacement, inches

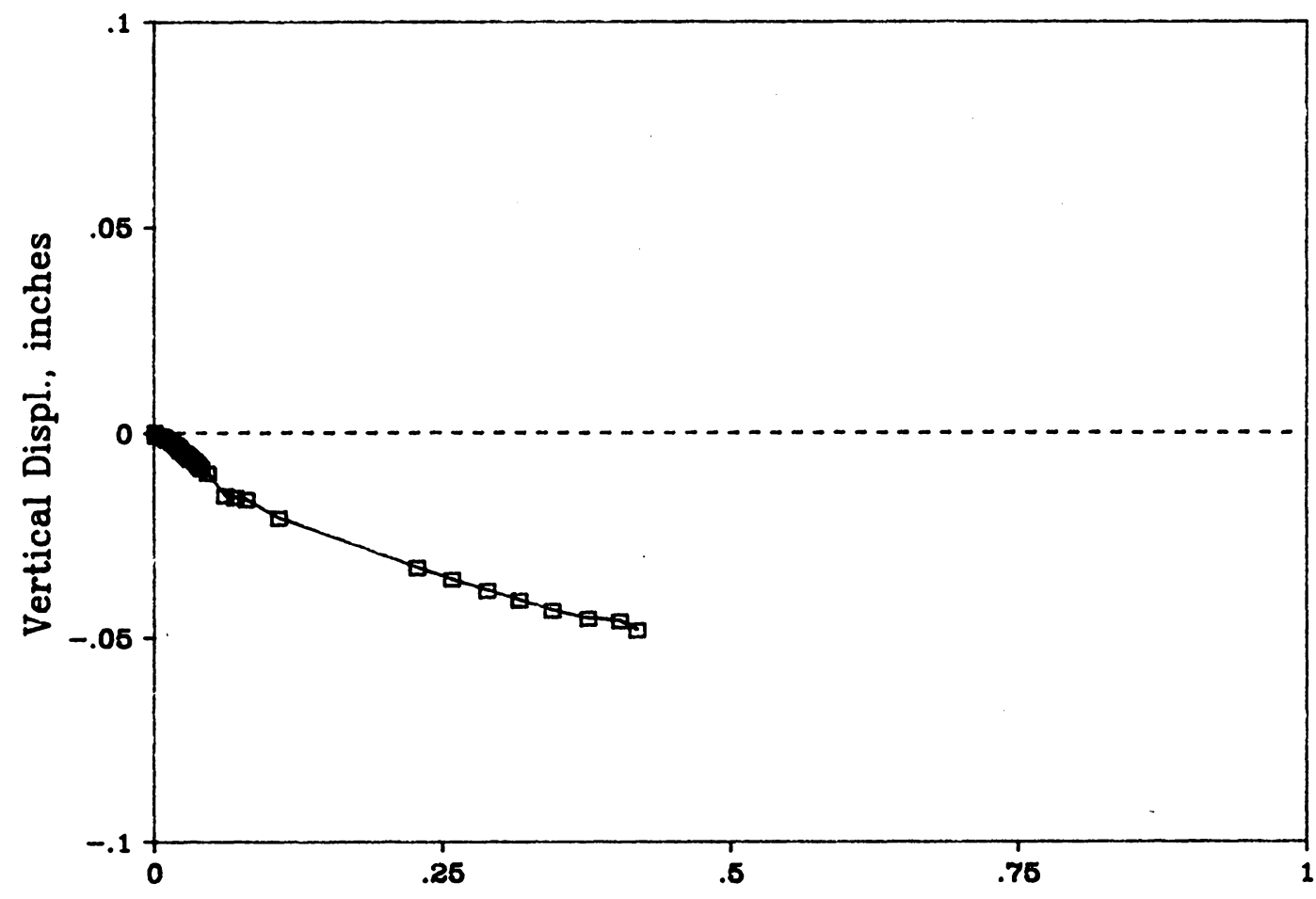

Horiz. Displacement, inches

Figure C-1 Direct Shear Test DS1101\#1S on Upstream Slopewash 

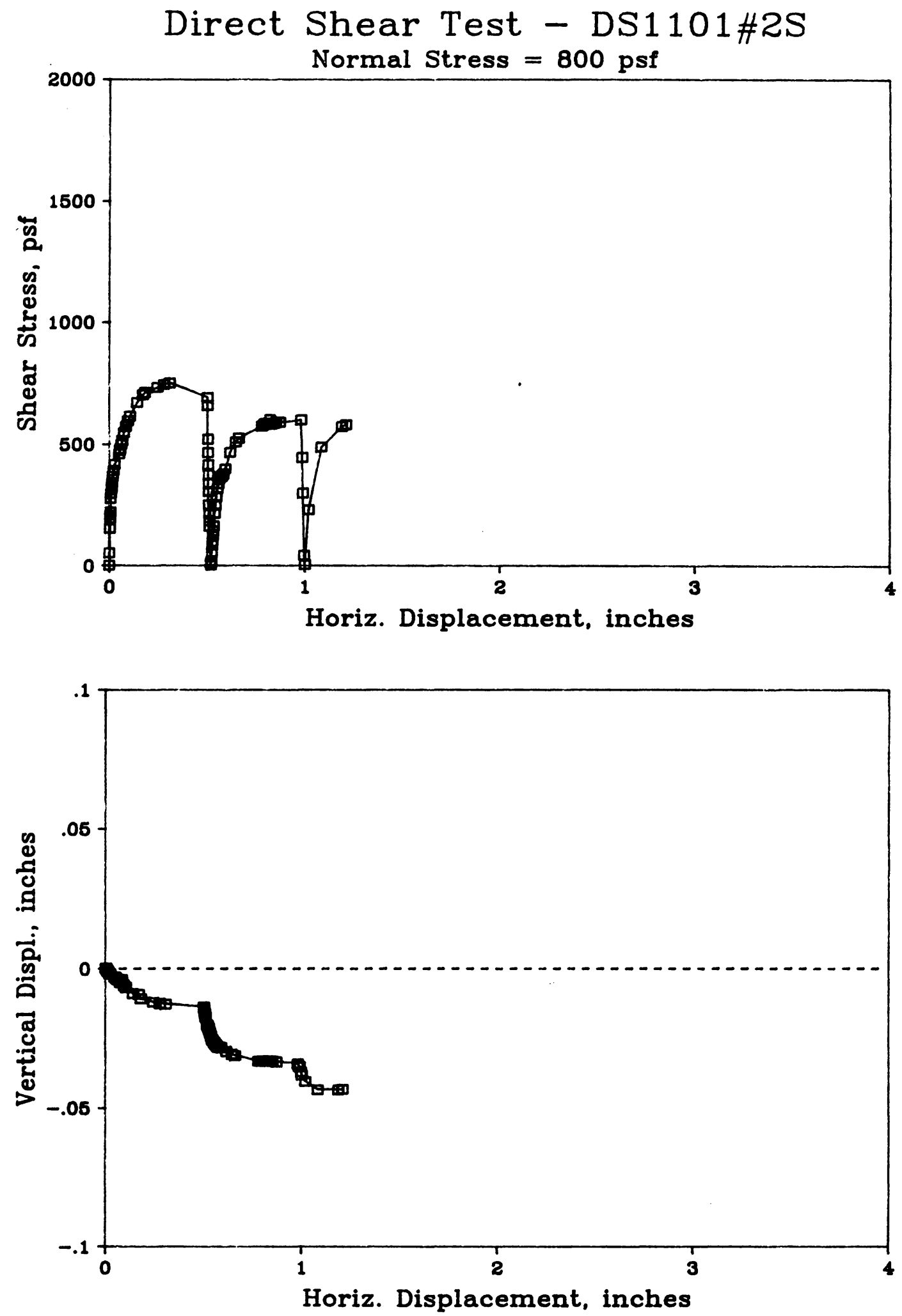

Figure C-2 Direct Shear Test DS1101\#2S on Upstream Slopewash 


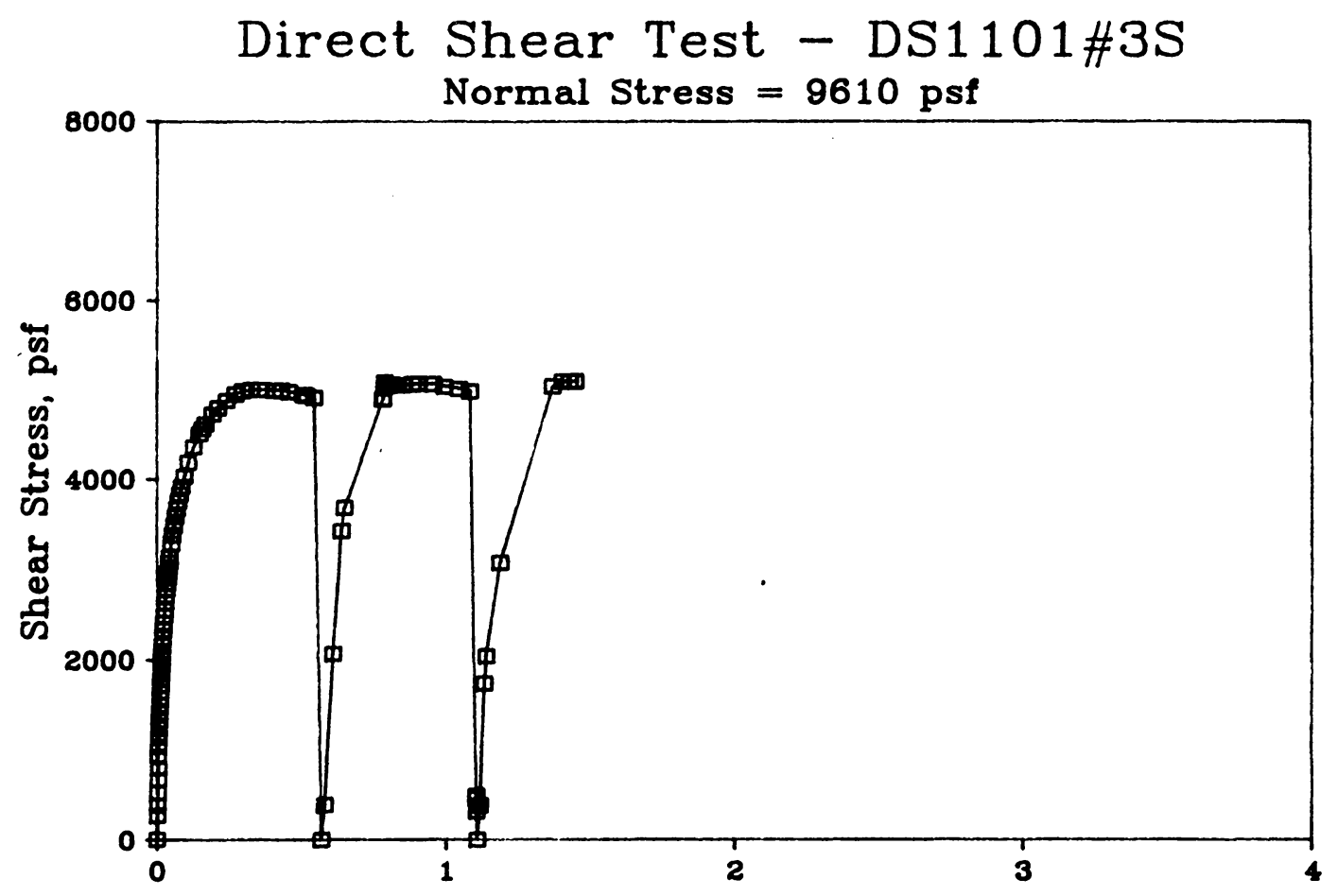

Horiz. Displacement, inches

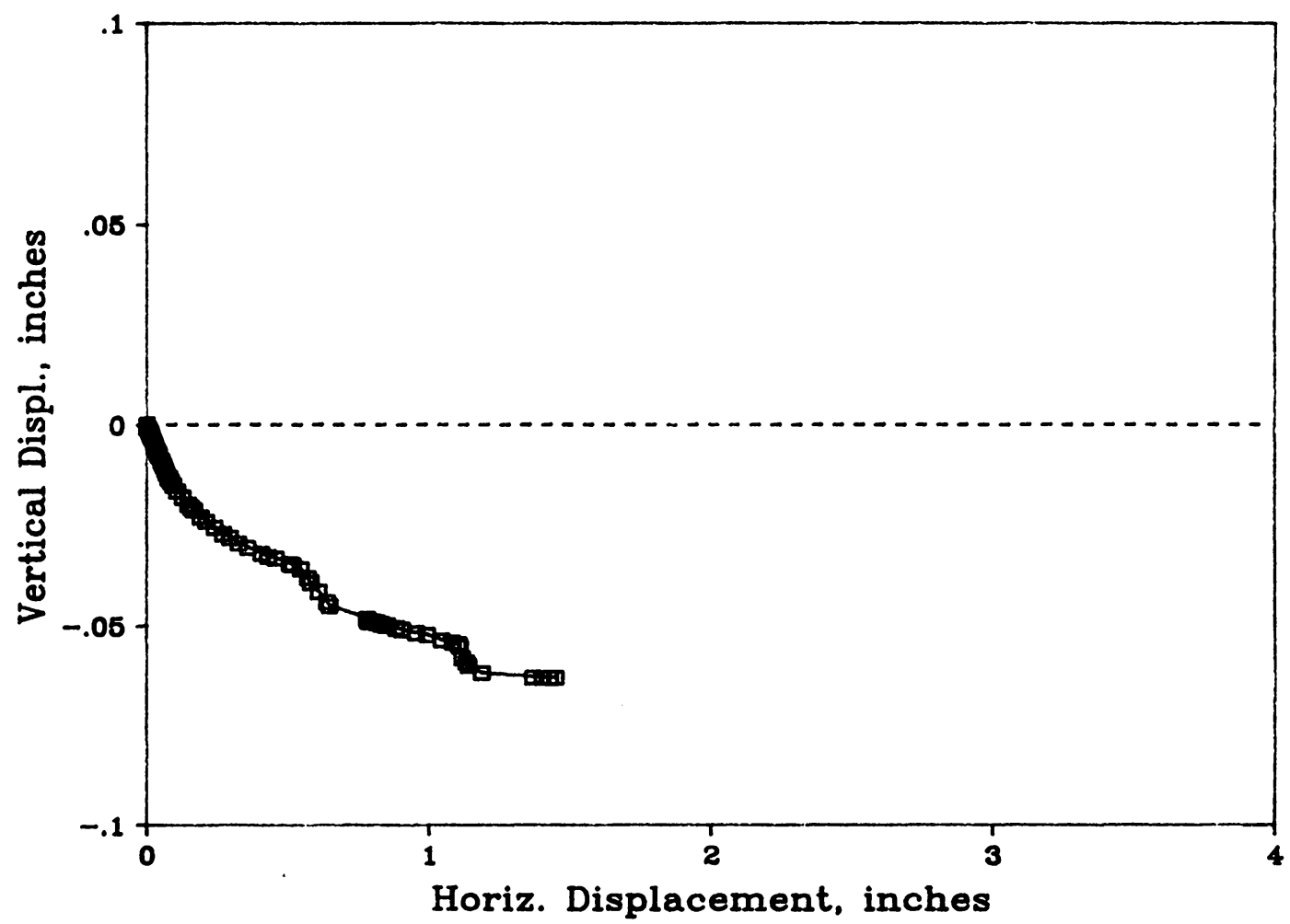

Figure C-3 Direct Shear Test DS1101\#3S on Upstream Slopewash 

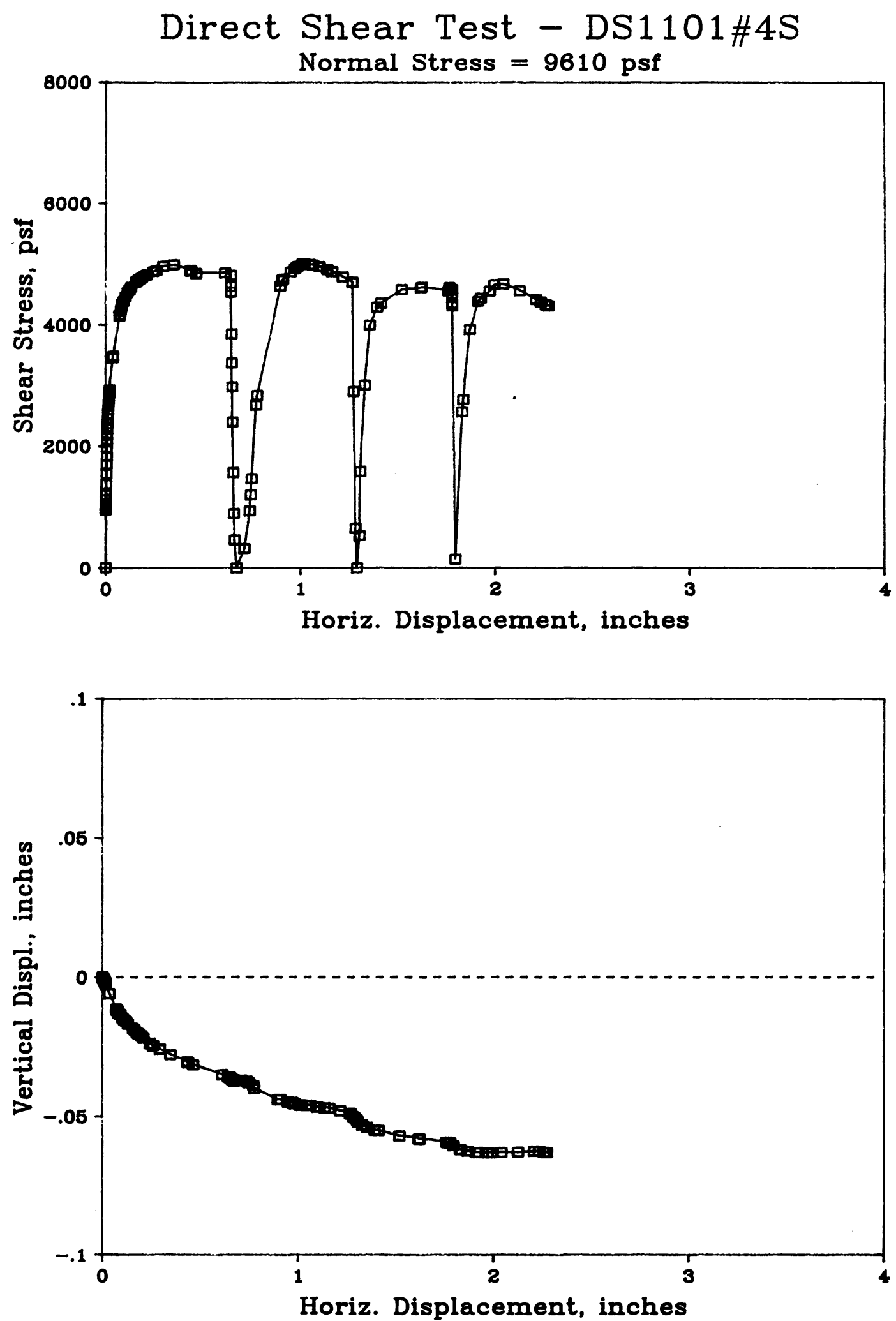

Figure C-4 Direct Shear Test DS1101\#4S on Upstream Slopewash 

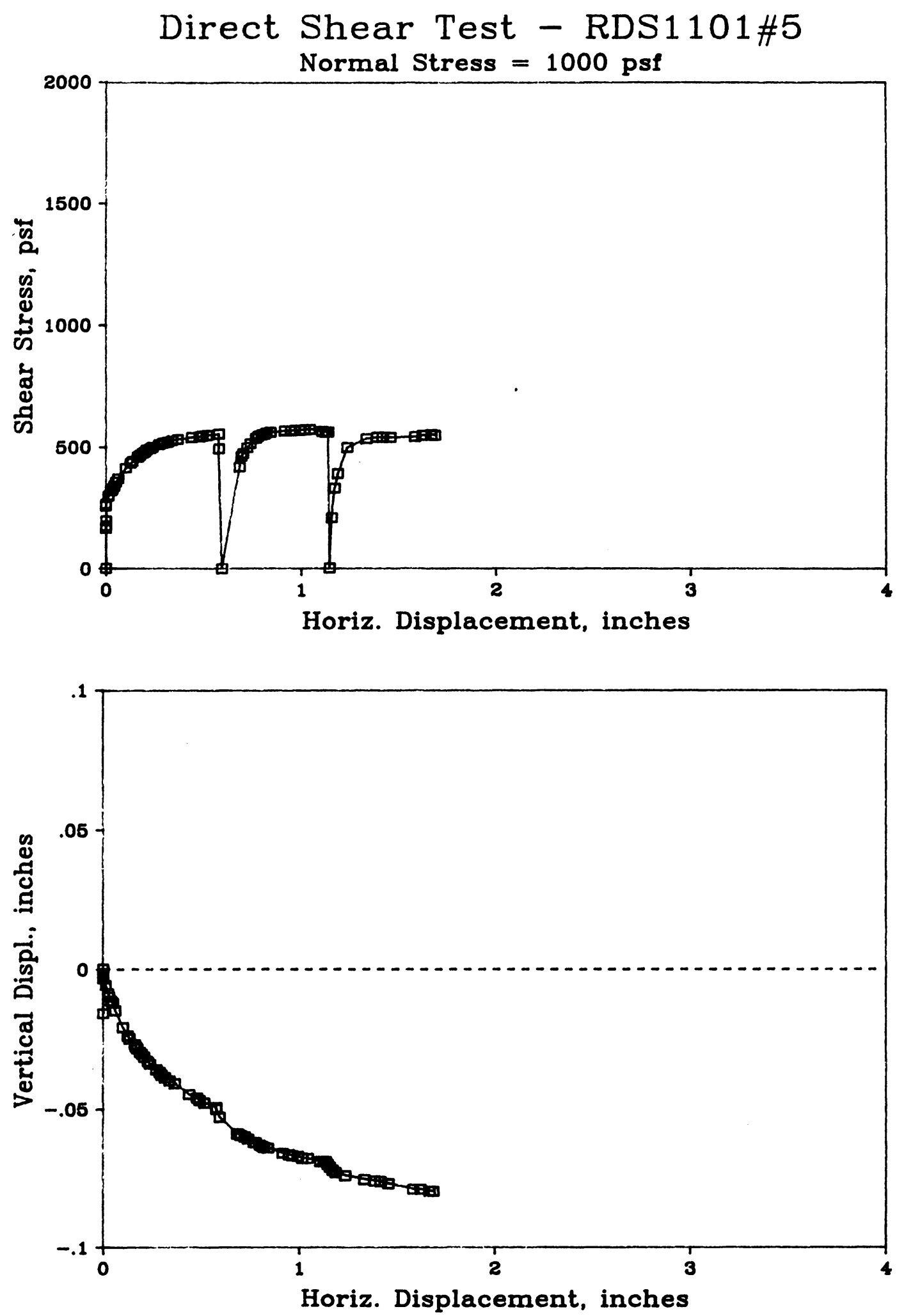

Figure C-5 Direct Shear Test RDS1101\#5 on Upstream Slopewash 
Direct Shear Test - RDS1101\#6

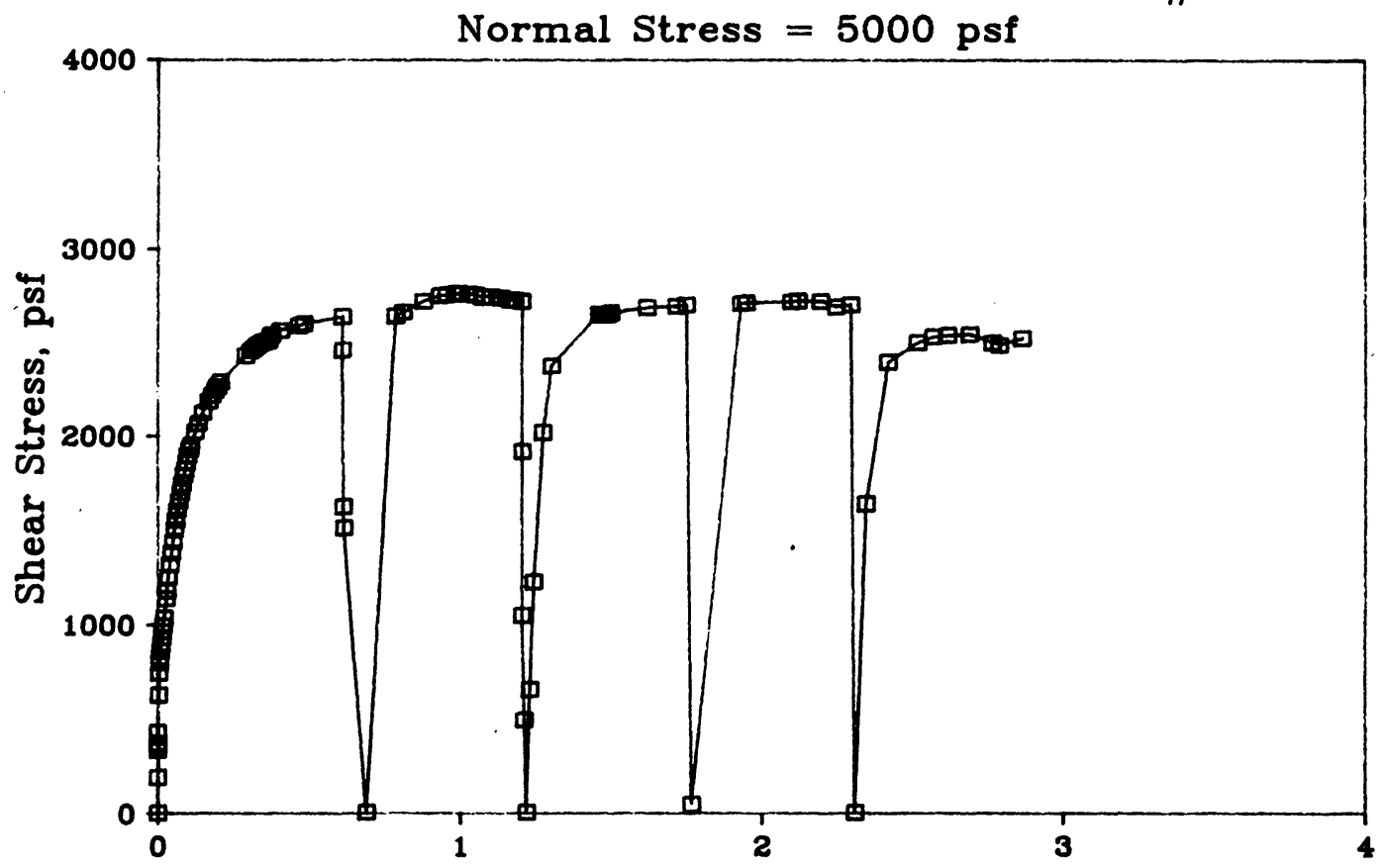

Horiz. Displacement, inches

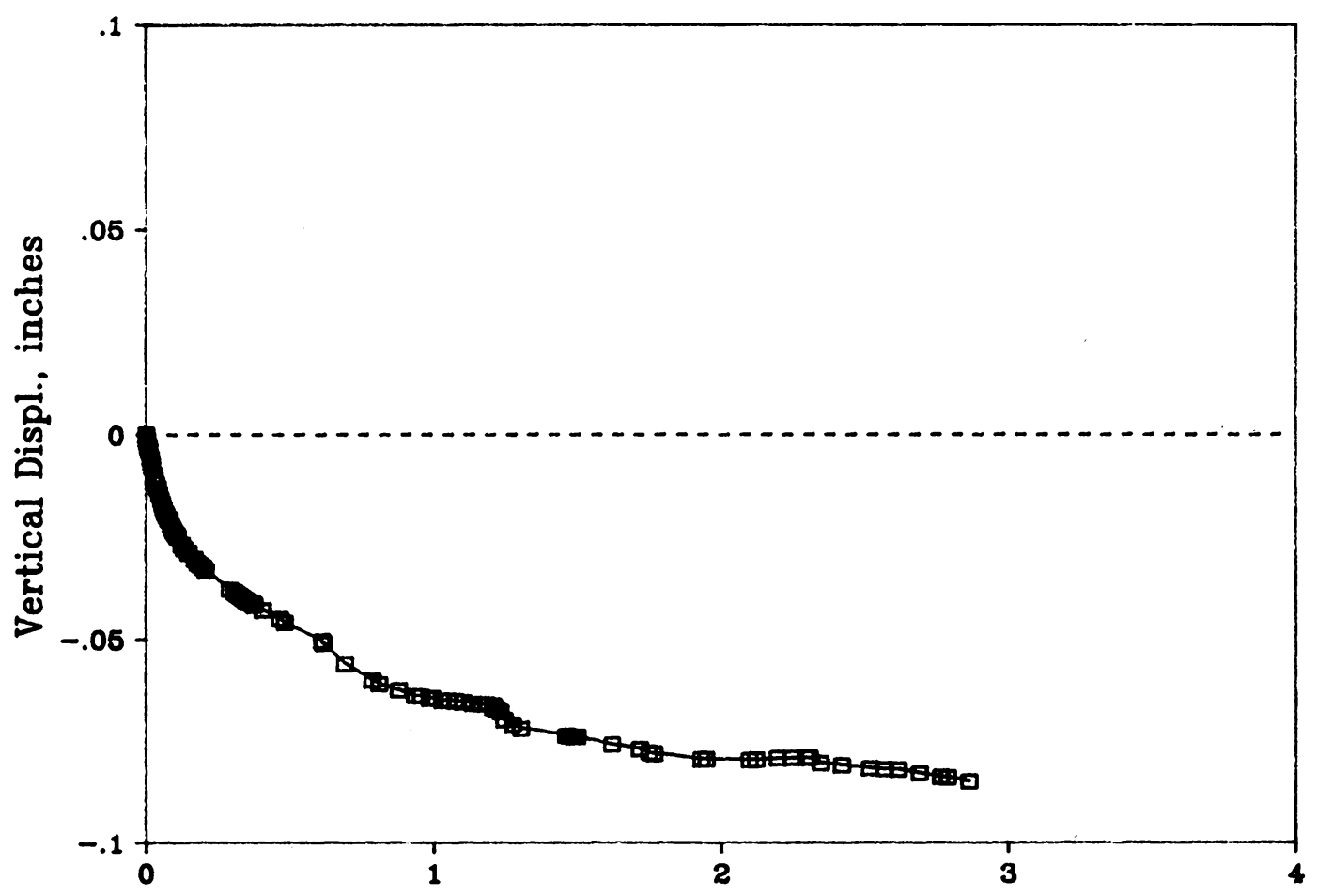

Horiz. Displacement, inches

Figure C-6 Direct Shear Test RDS1101\#6 on Upstream Slopewash 

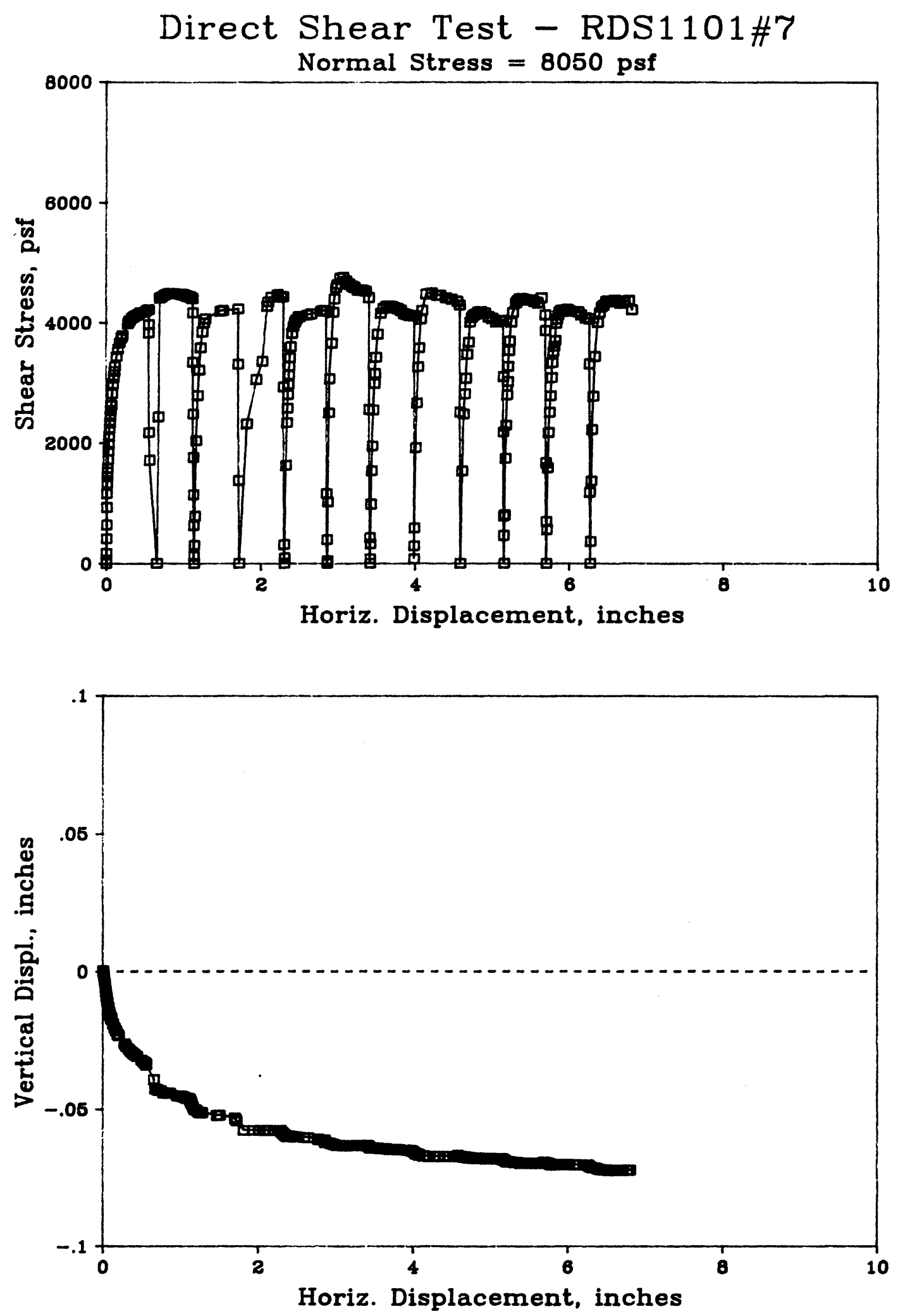

Figure C-7 Direct Shear Test RDS1101\#7 on Upstream Slopewash 

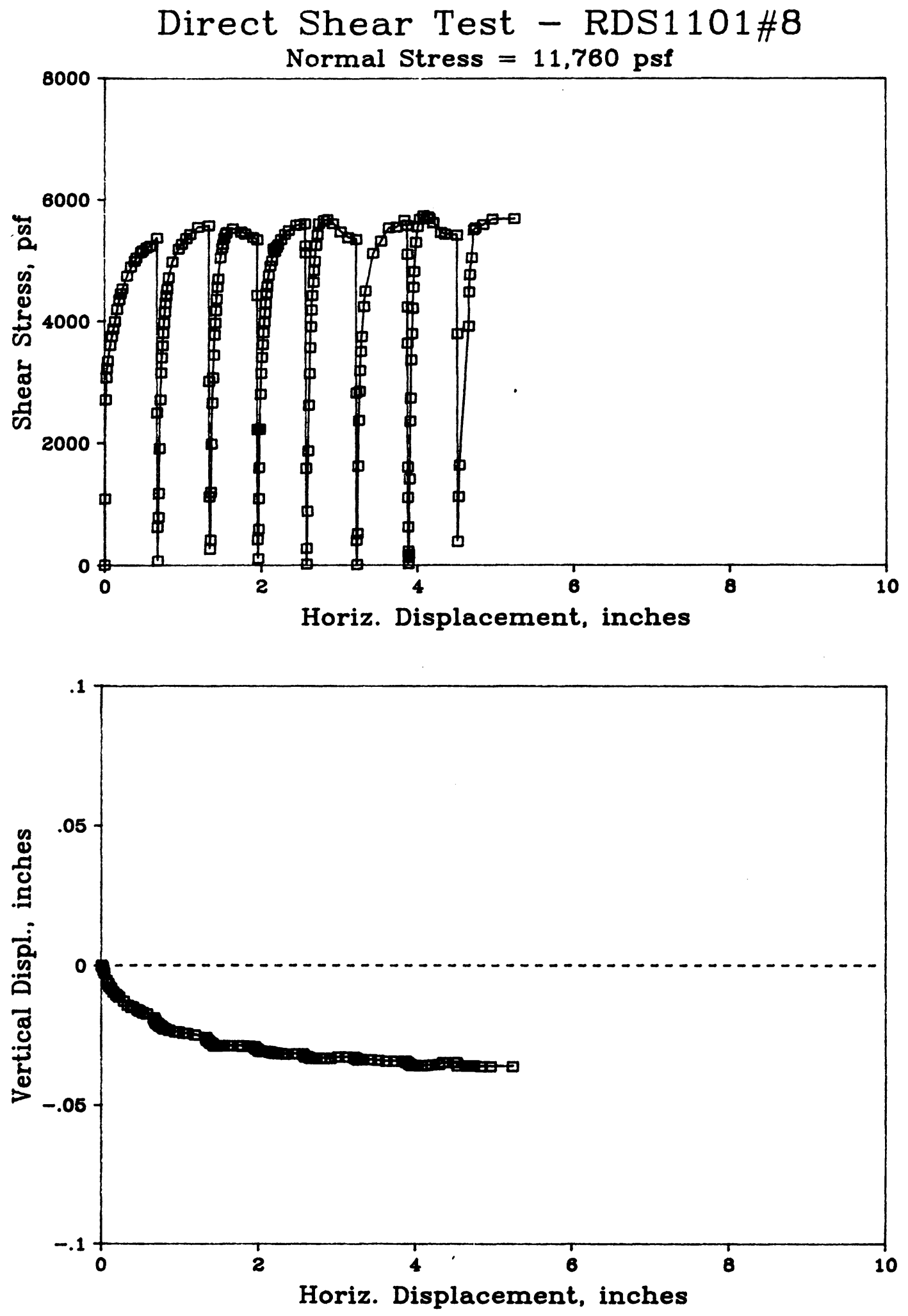

Figure C-8 Direct Shear Test RDS1101\#8 on Upstream Slopewash 

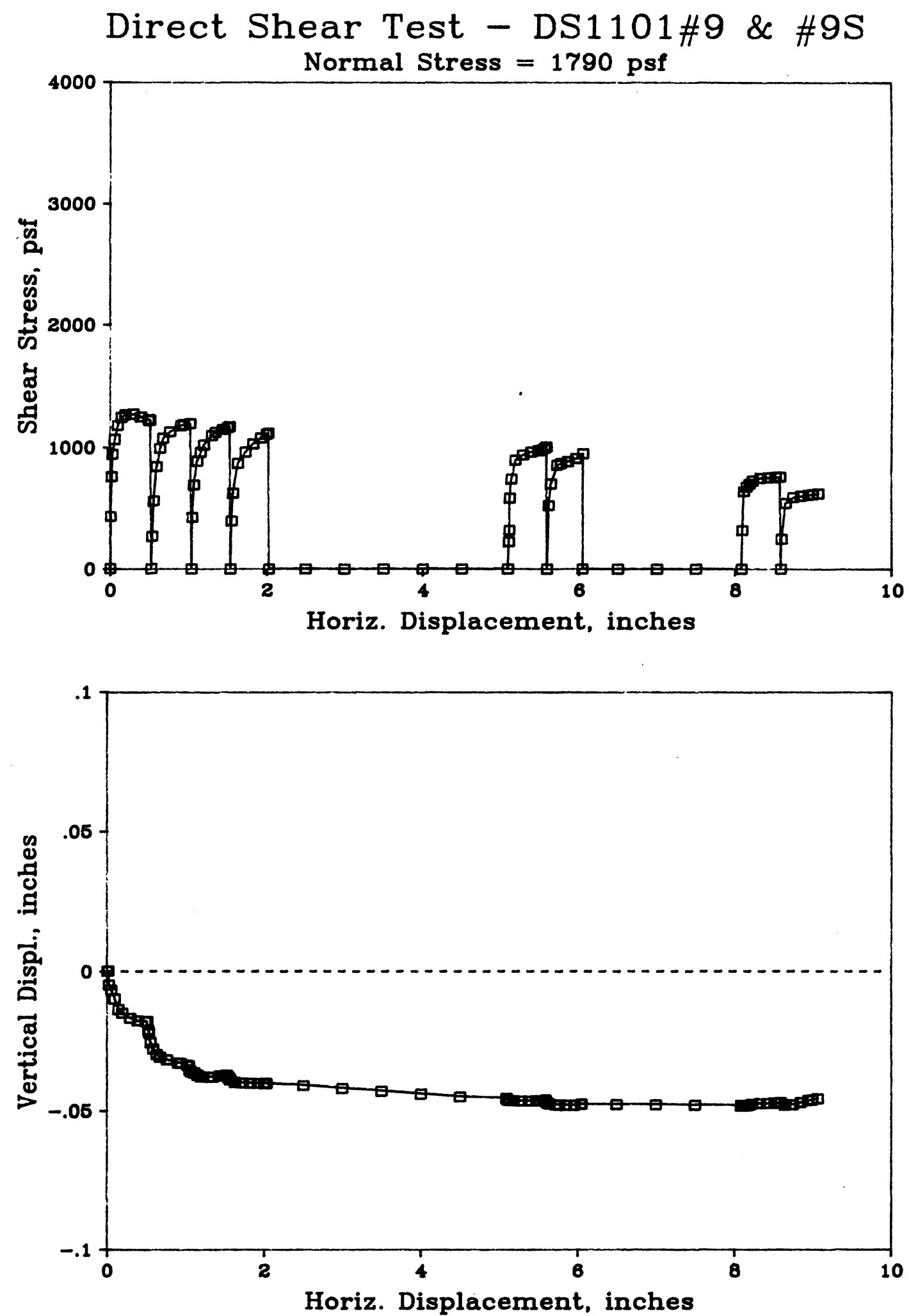

Figure C-9 Direct Shear Test DS1101\#9 \& \#9S on Upstream Slopewash 

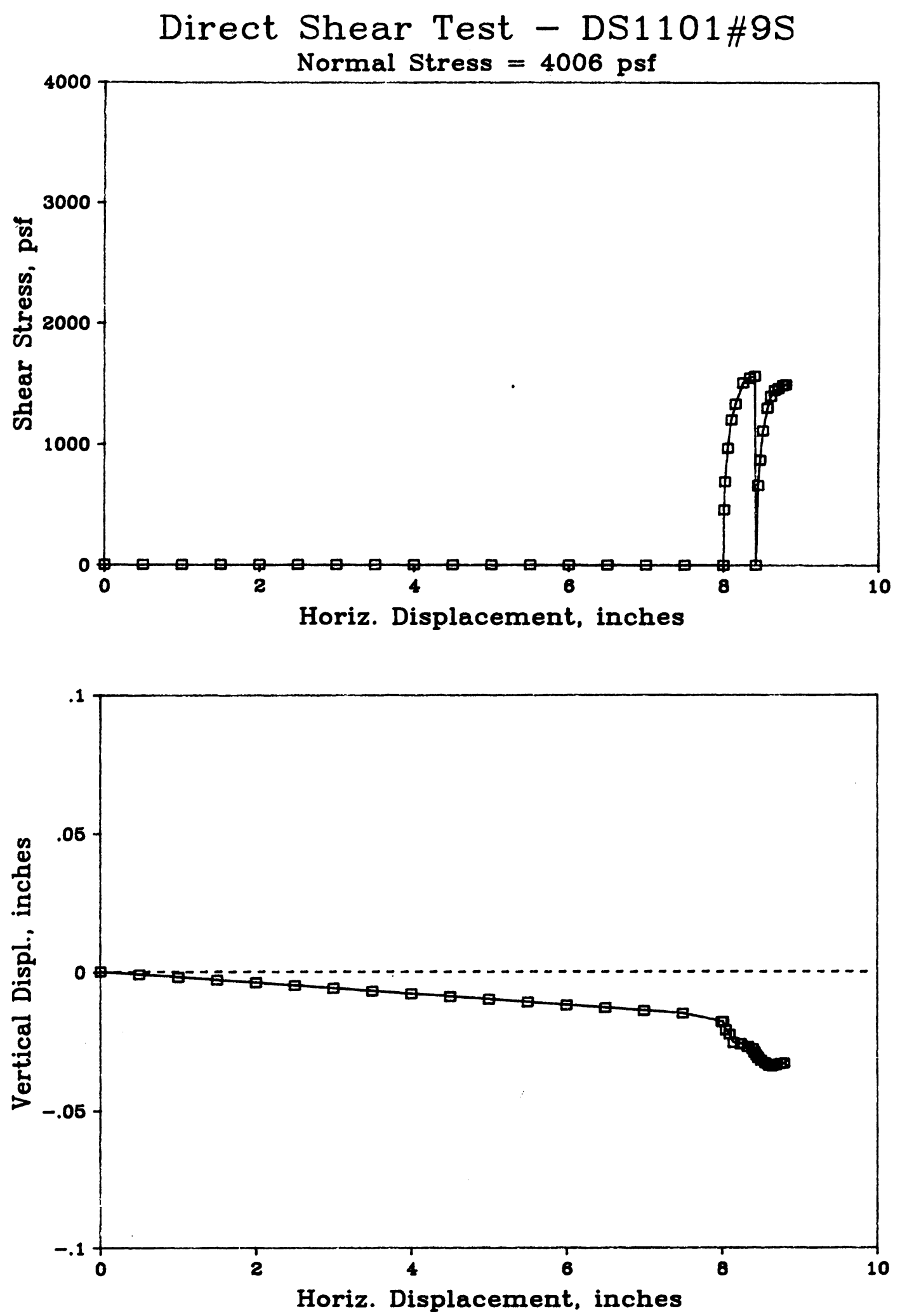

Figure C-10 Direct Shear Test DS1101\#9S on Upstream Slopewash 

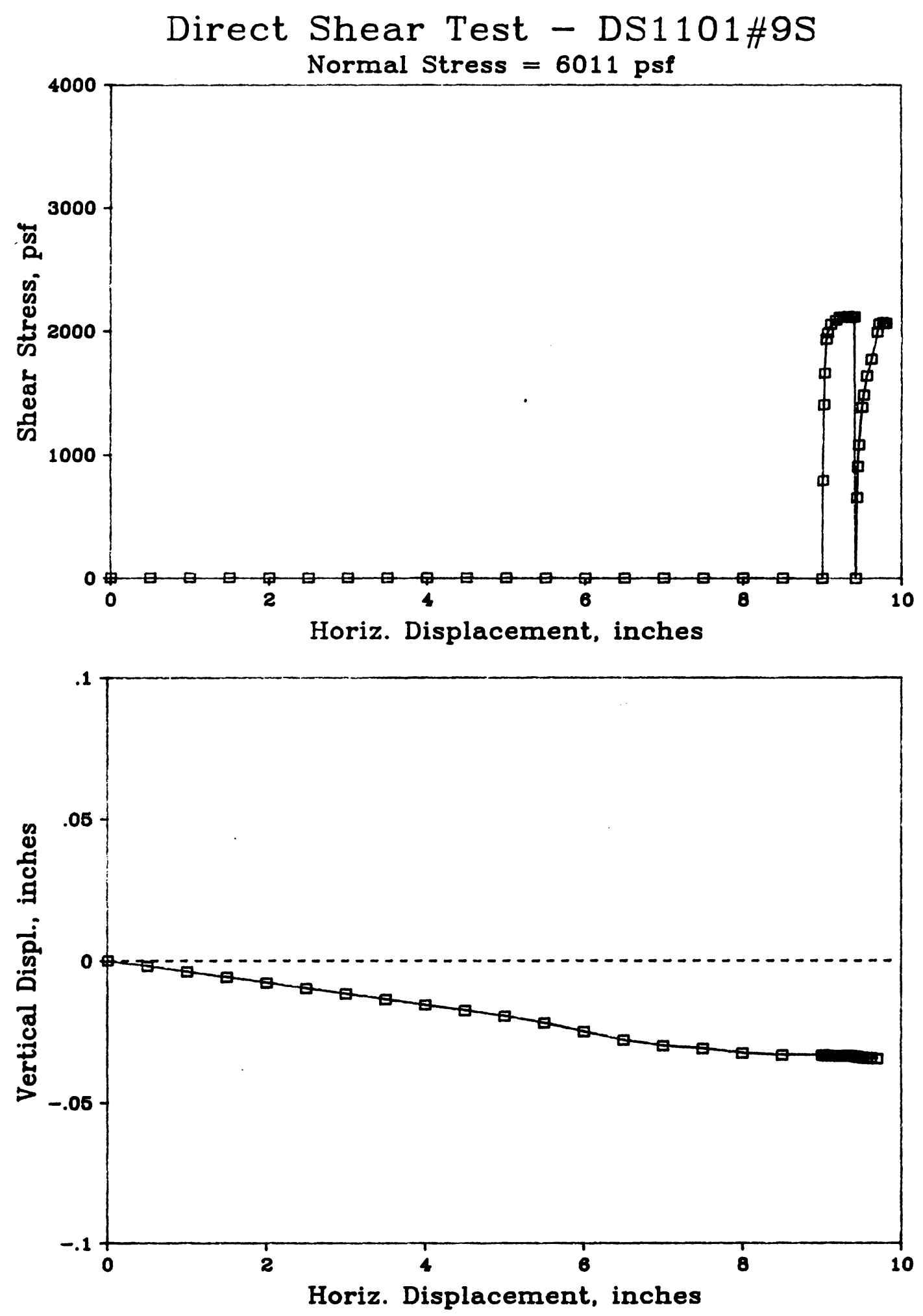

Figure C-11 Direct Shear Test DS1101\#9S on Opstream Slopewash 

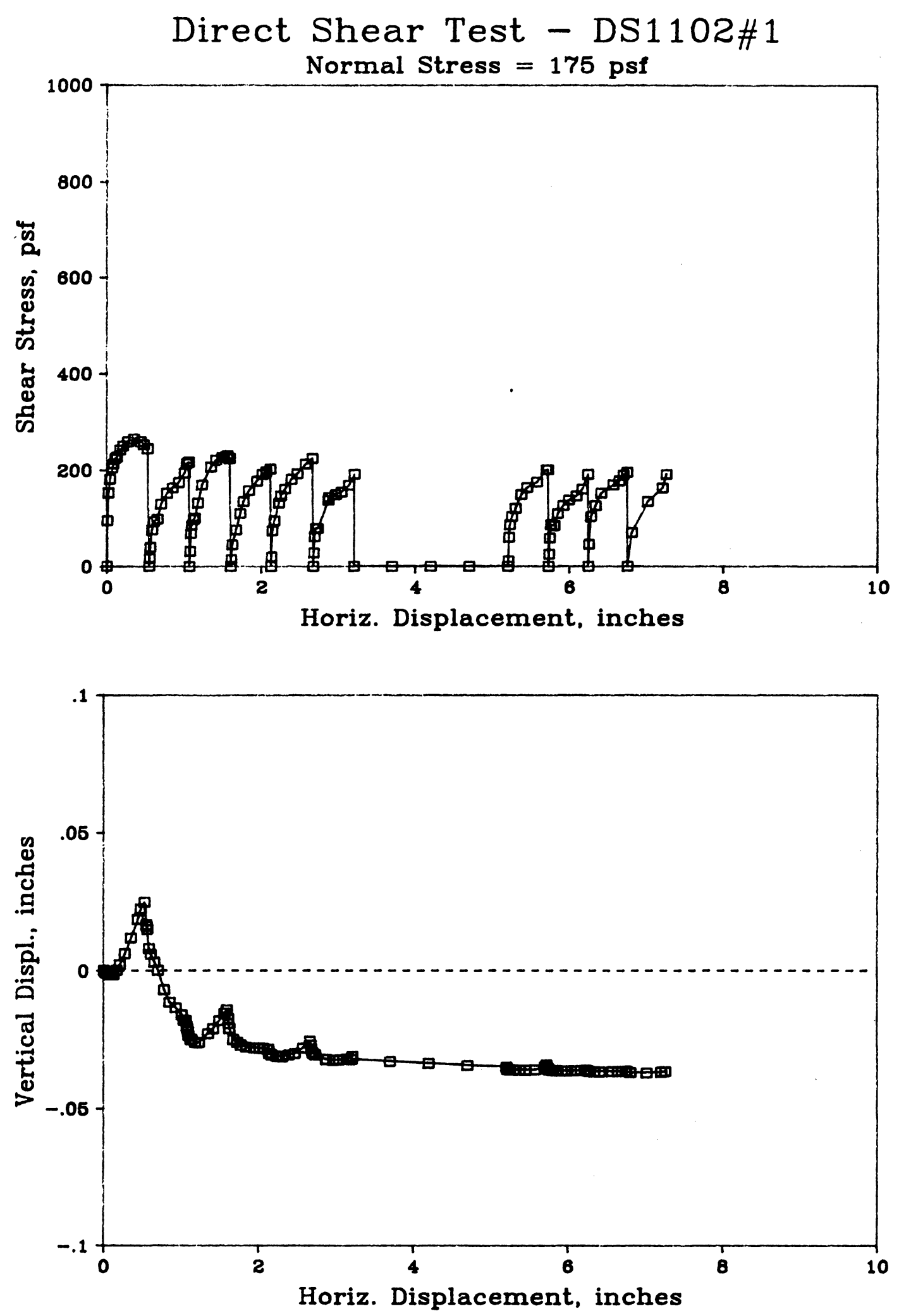

Figure C-12 Direct Shear Test DS1102\#1 on Upstream Slopewash 

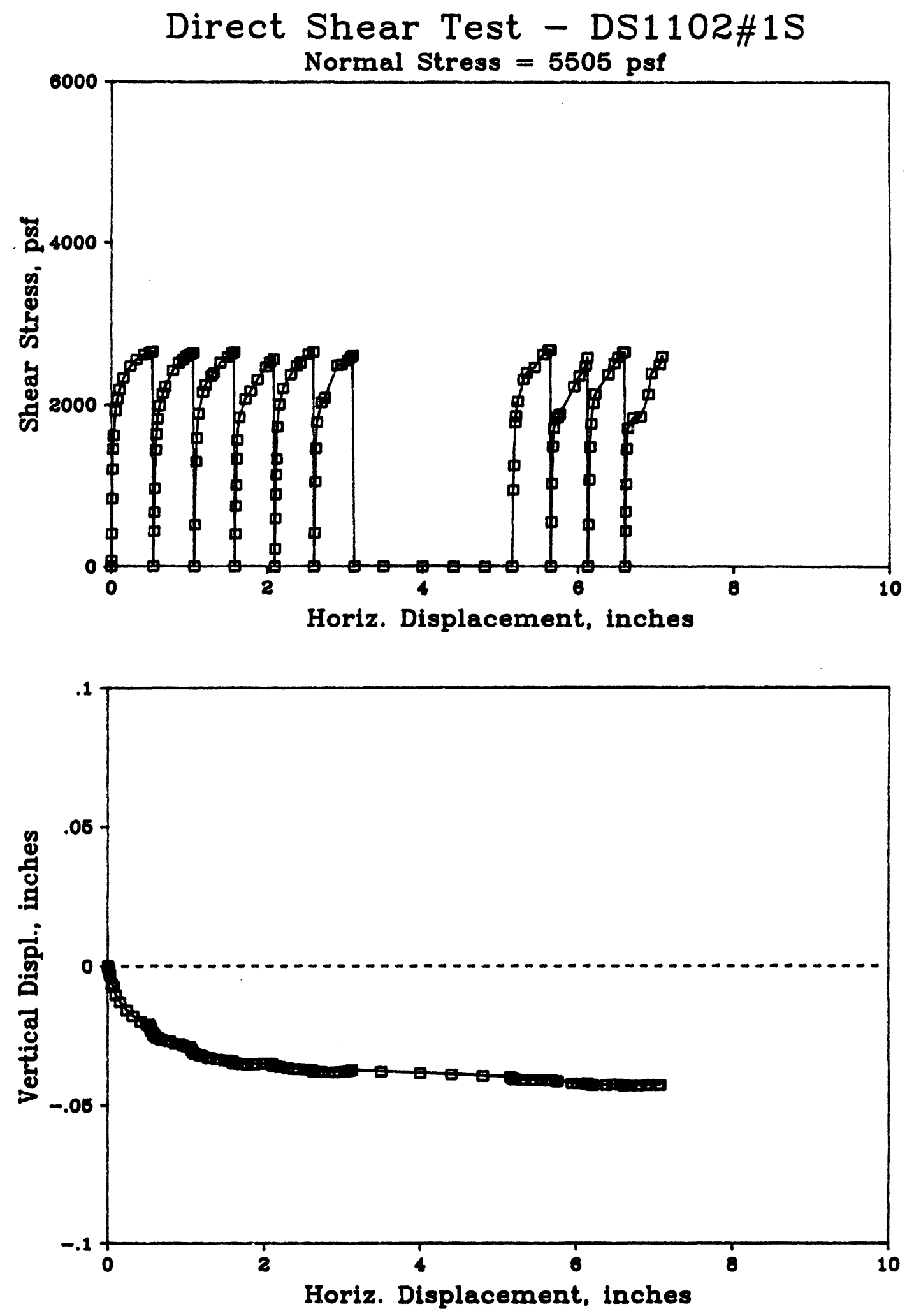

Figure C-13 Direct Shear Test DS1102\#1S on Upstream Slopewash 
Direct Shear Test - DS1102\#1S

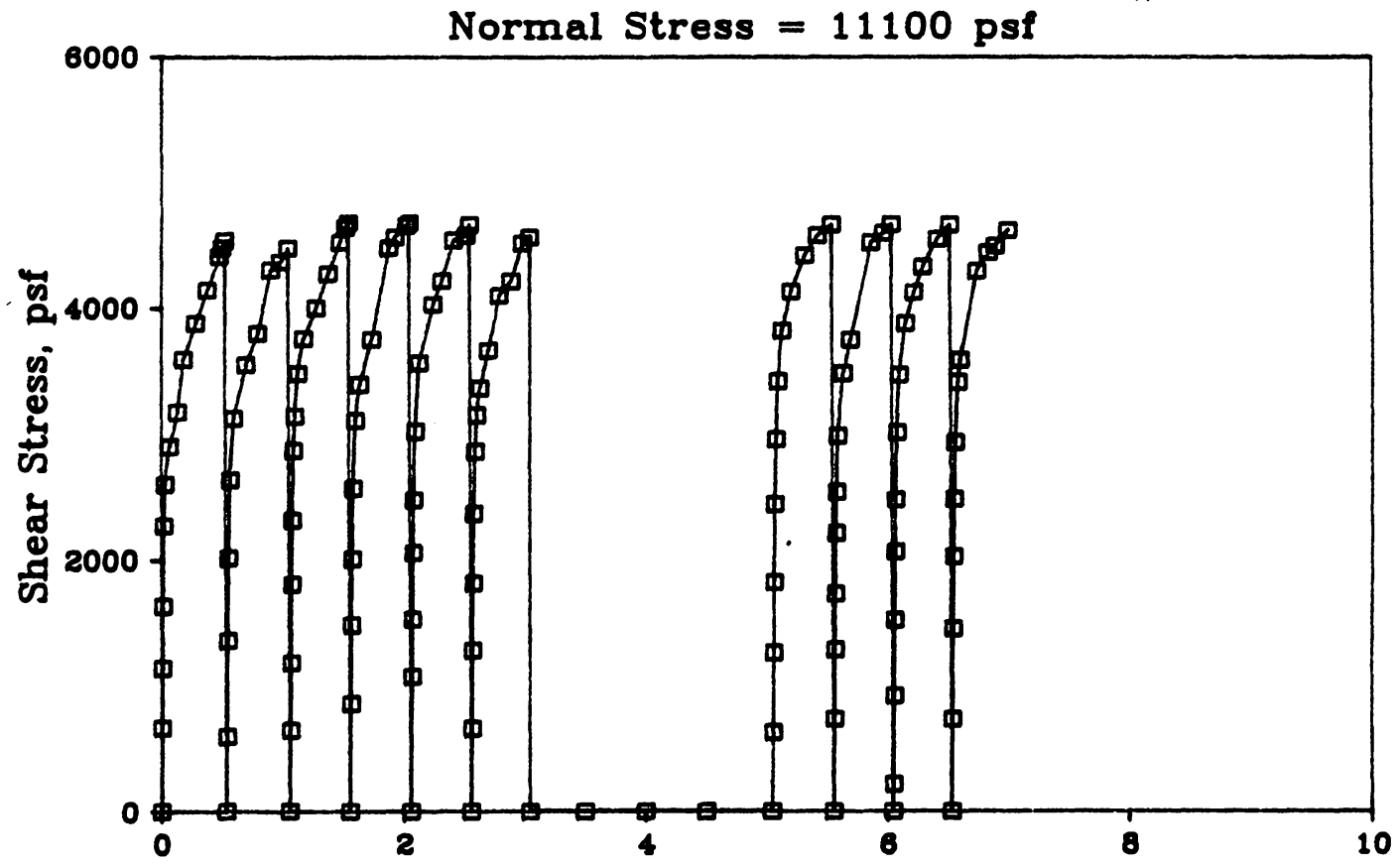

Horiz. Displacement, inches

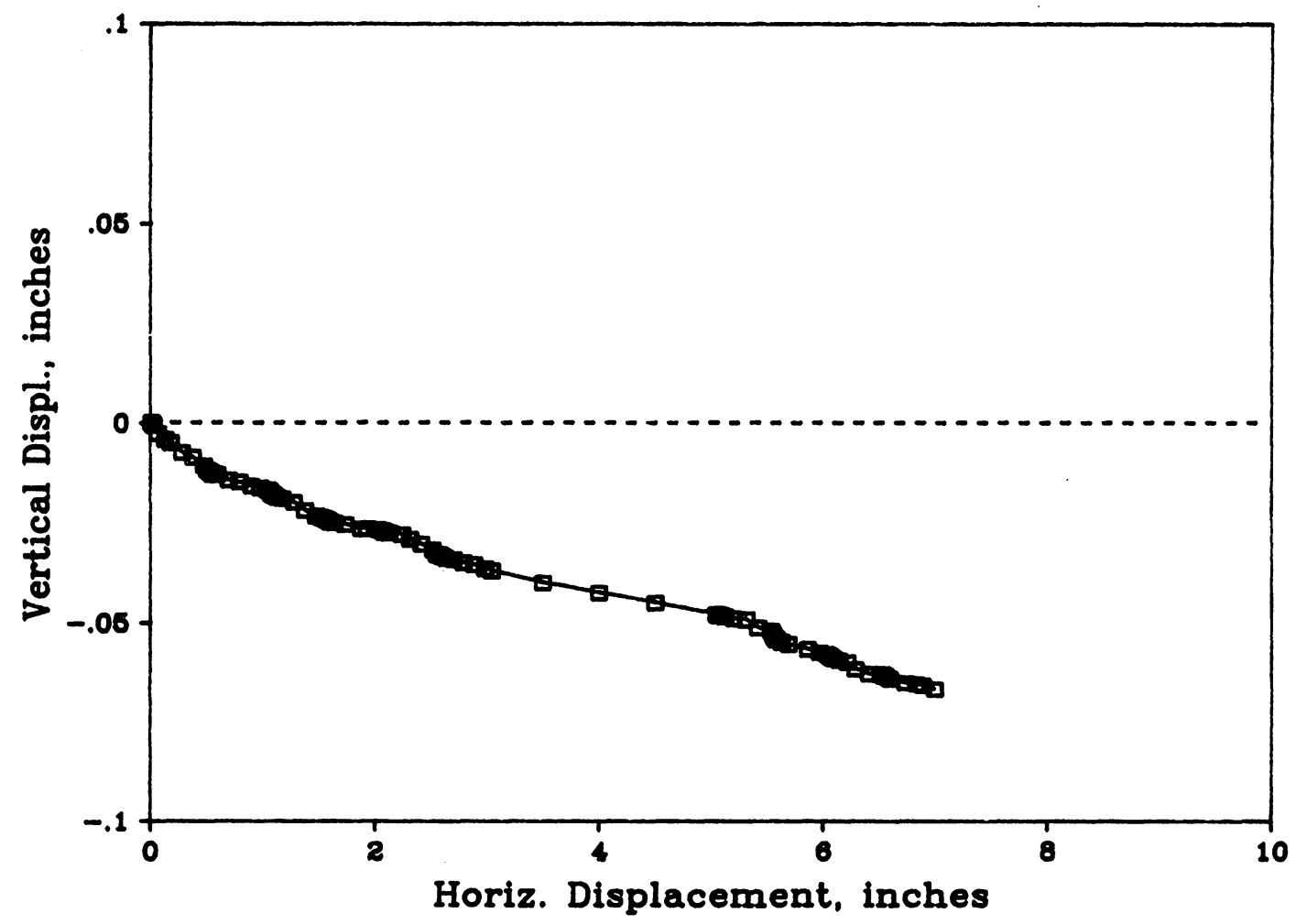

Figure C-14 Direct Shear Test DS1102\#1S on Upstream Slopewash 

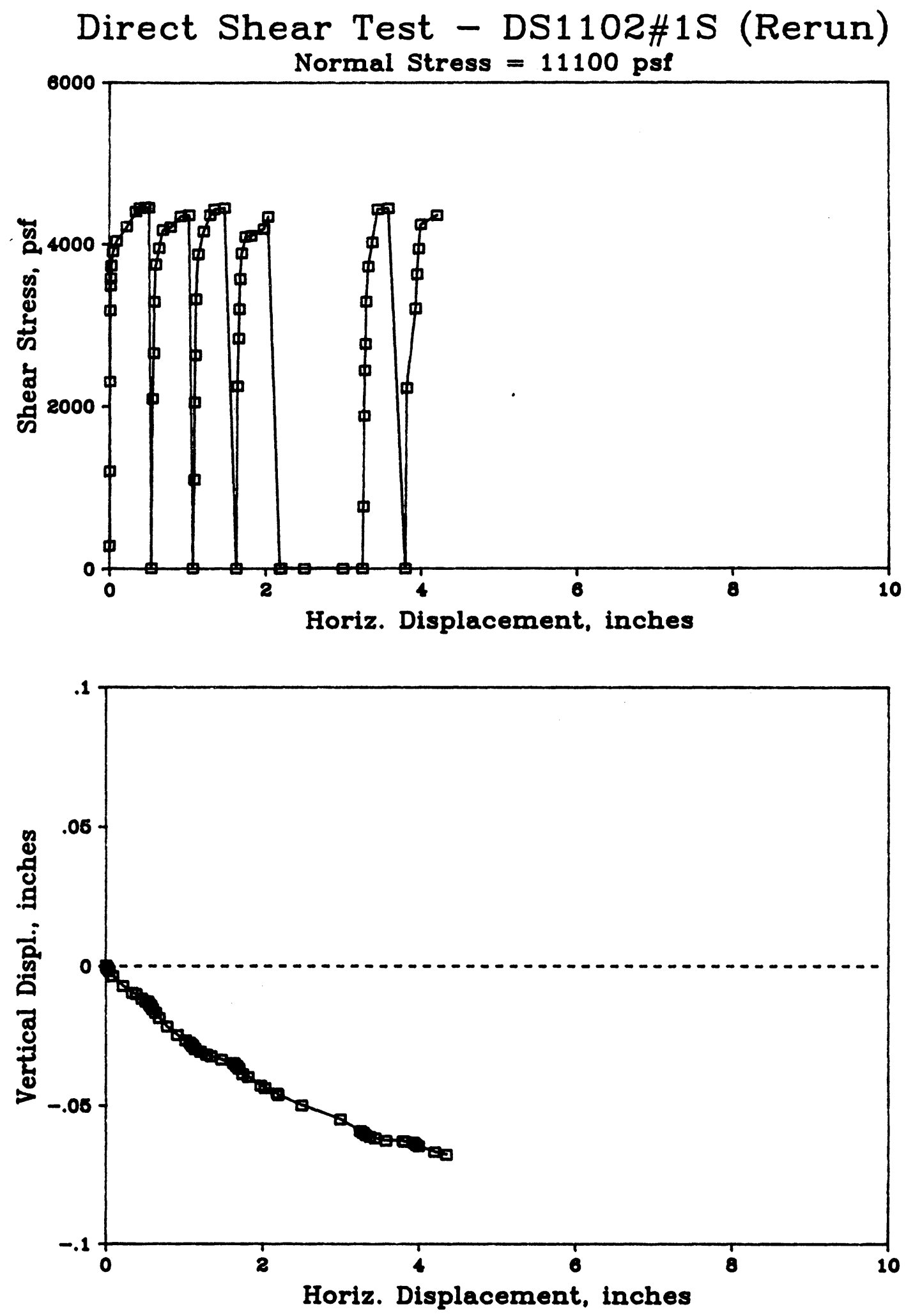

Figure C-15 Direct Shear Test DS1102\#1S (Rerun) on Upstream Slopewash 

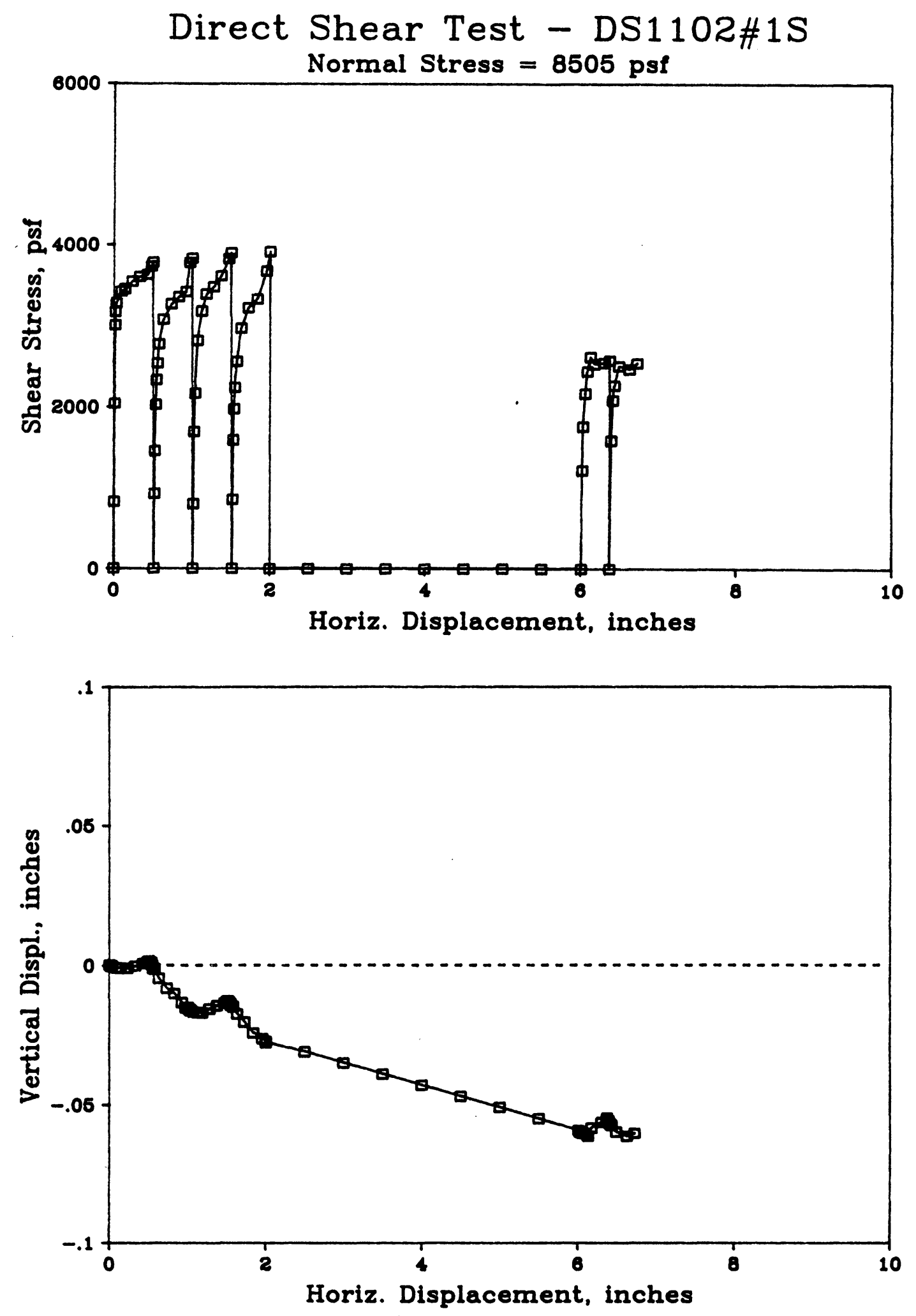

Figure C-16 Direct Shear Test DS1102\#1S on Upstream Slopewash 

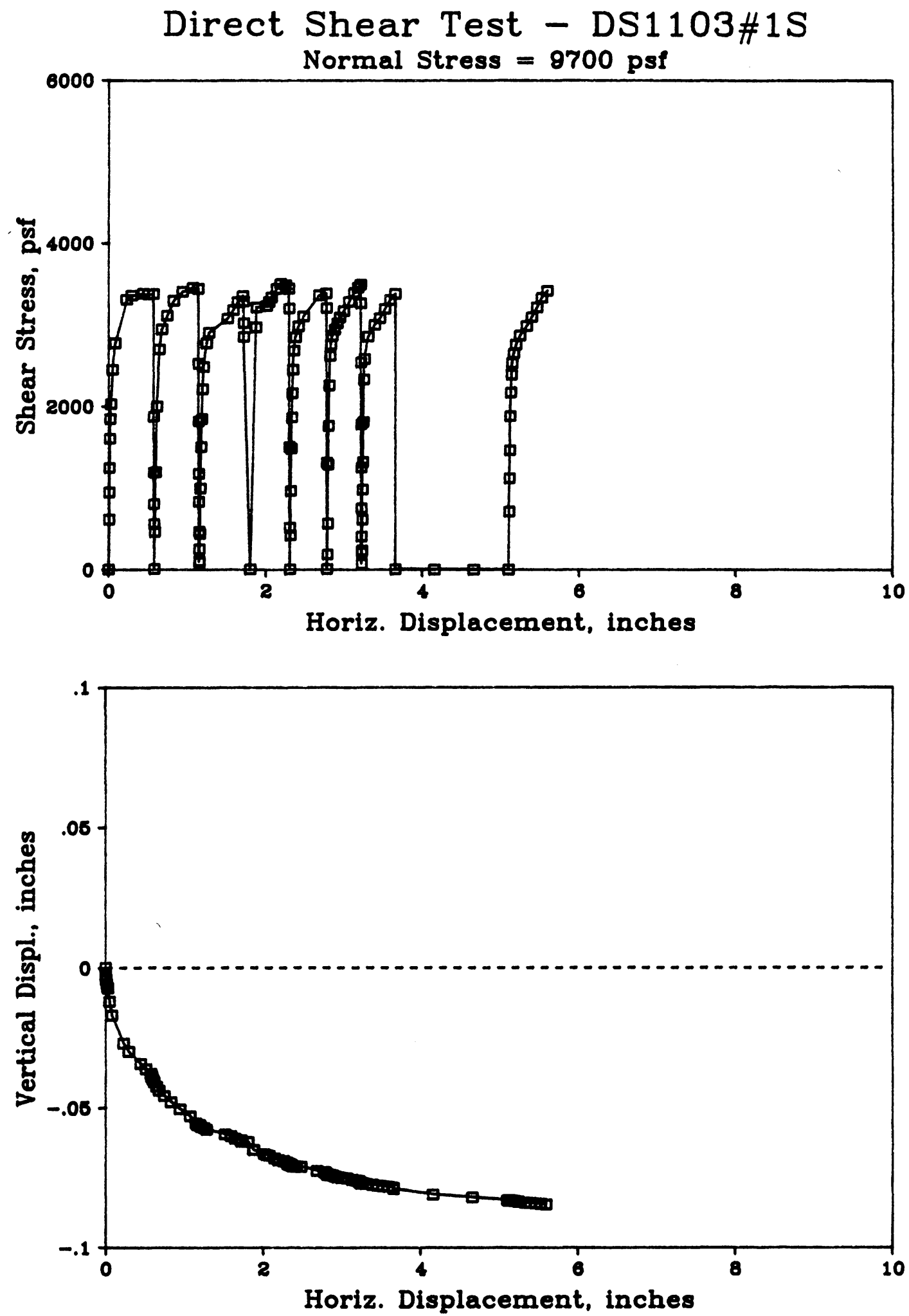

Figure C-17 Direct Shear Test DS1103\#1S on Downstream Slopewash 
Direct Shear Test - DS1103\#2
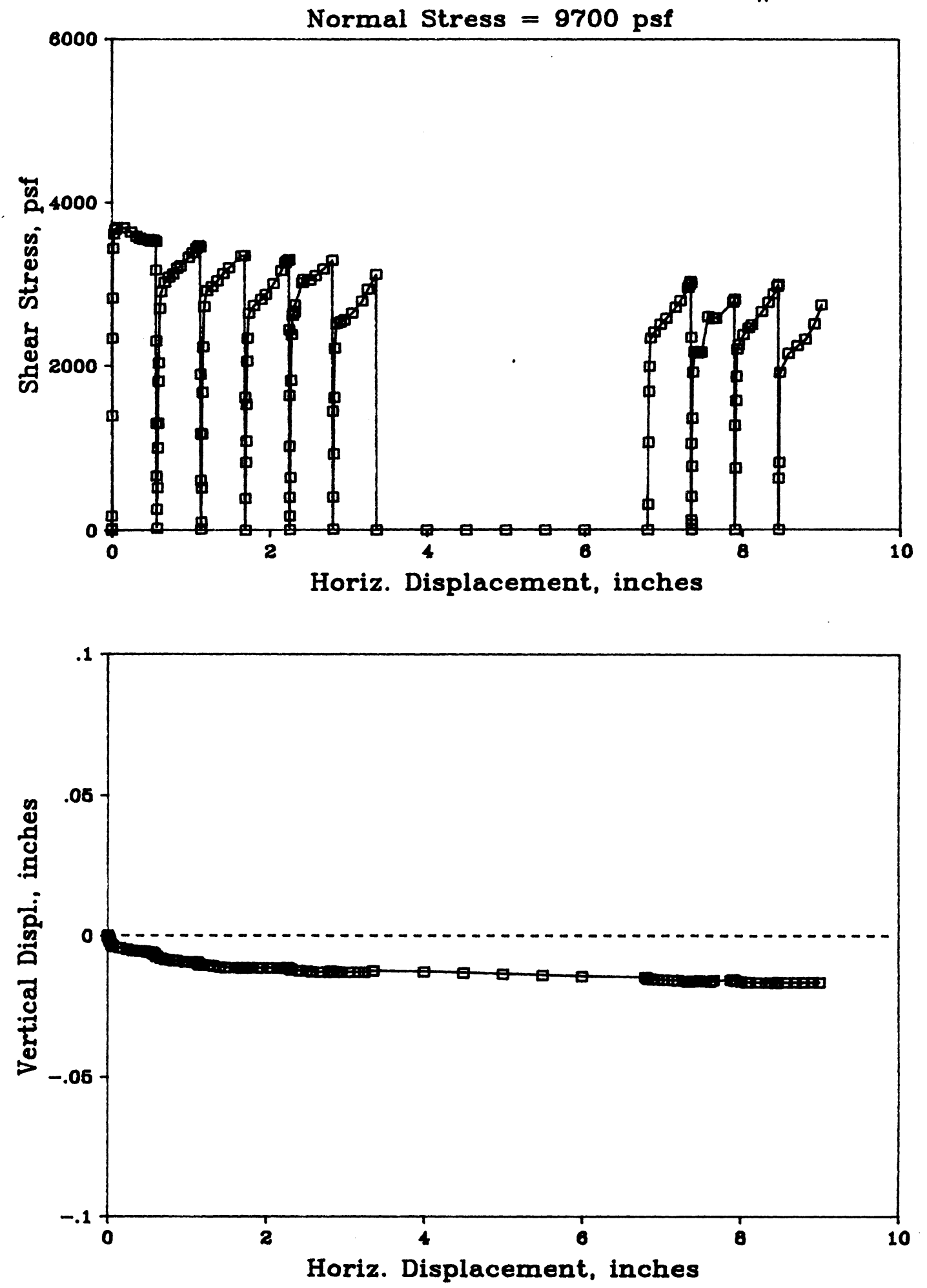

Figure C-18 Direct Shear Test DS1103\#2 on Downstream Slopewash 

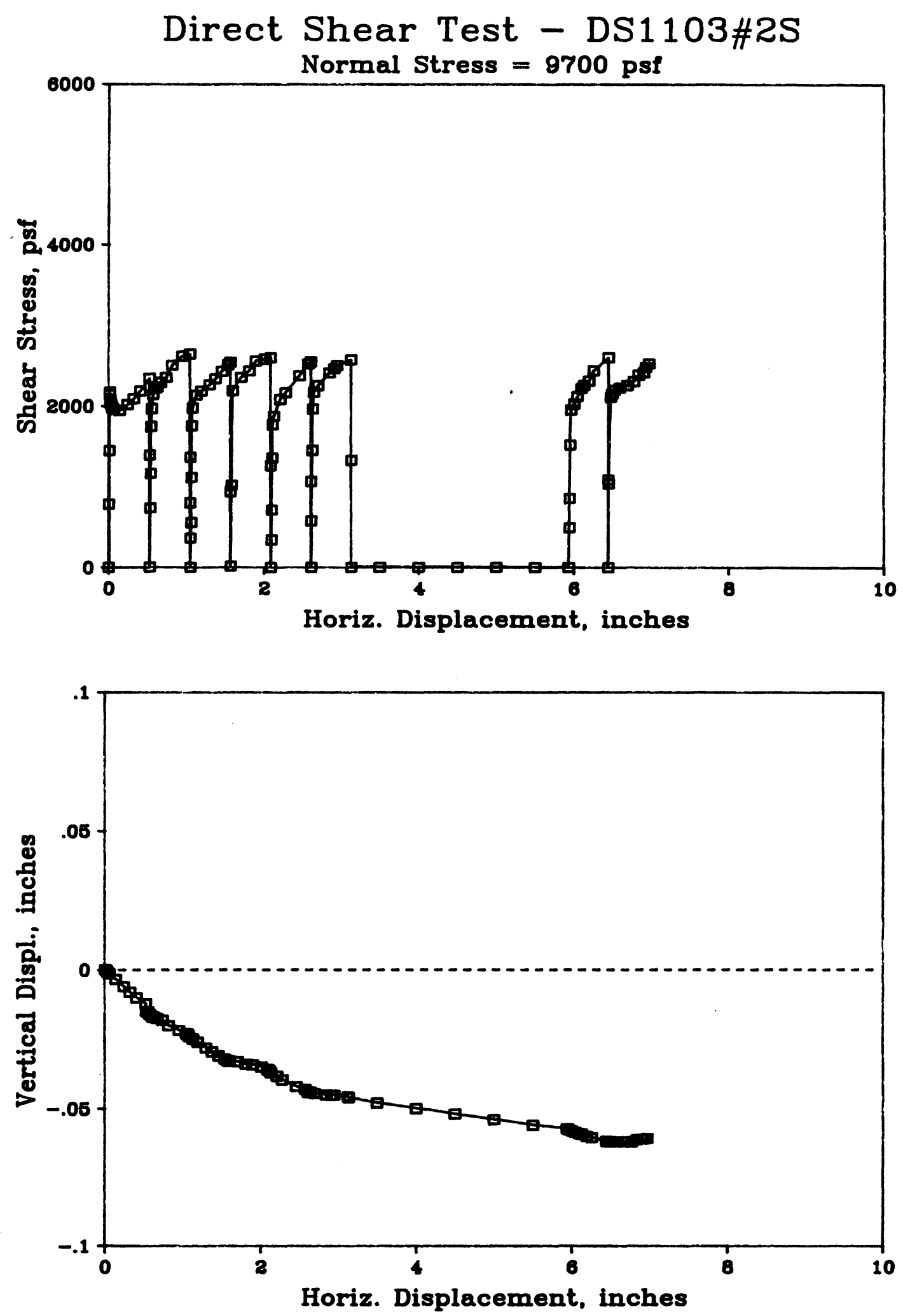

Figure C-19 Direct Shear Test DS1103\#2S on Downstream Slopewash 


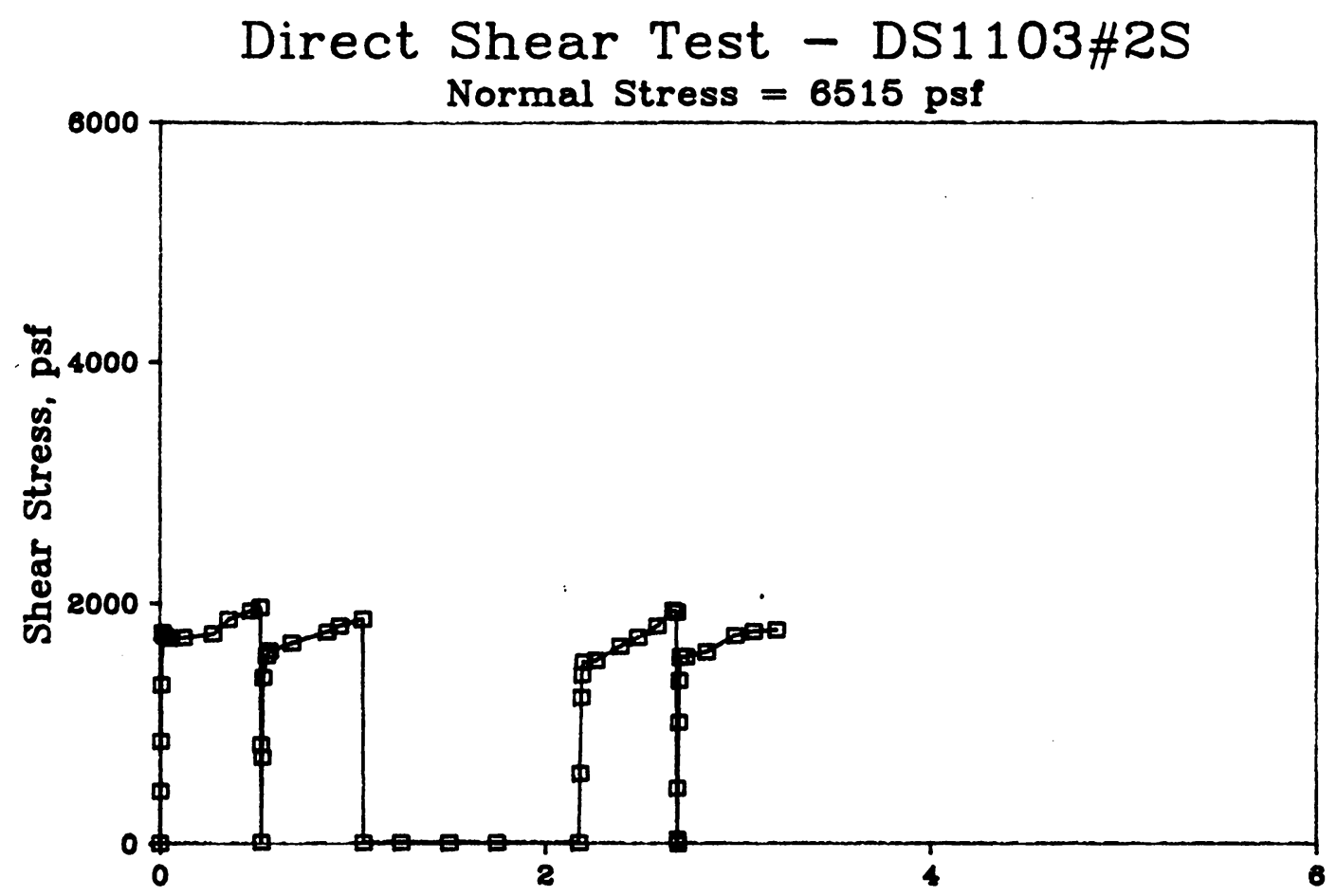

Horiz. Displacement, inches

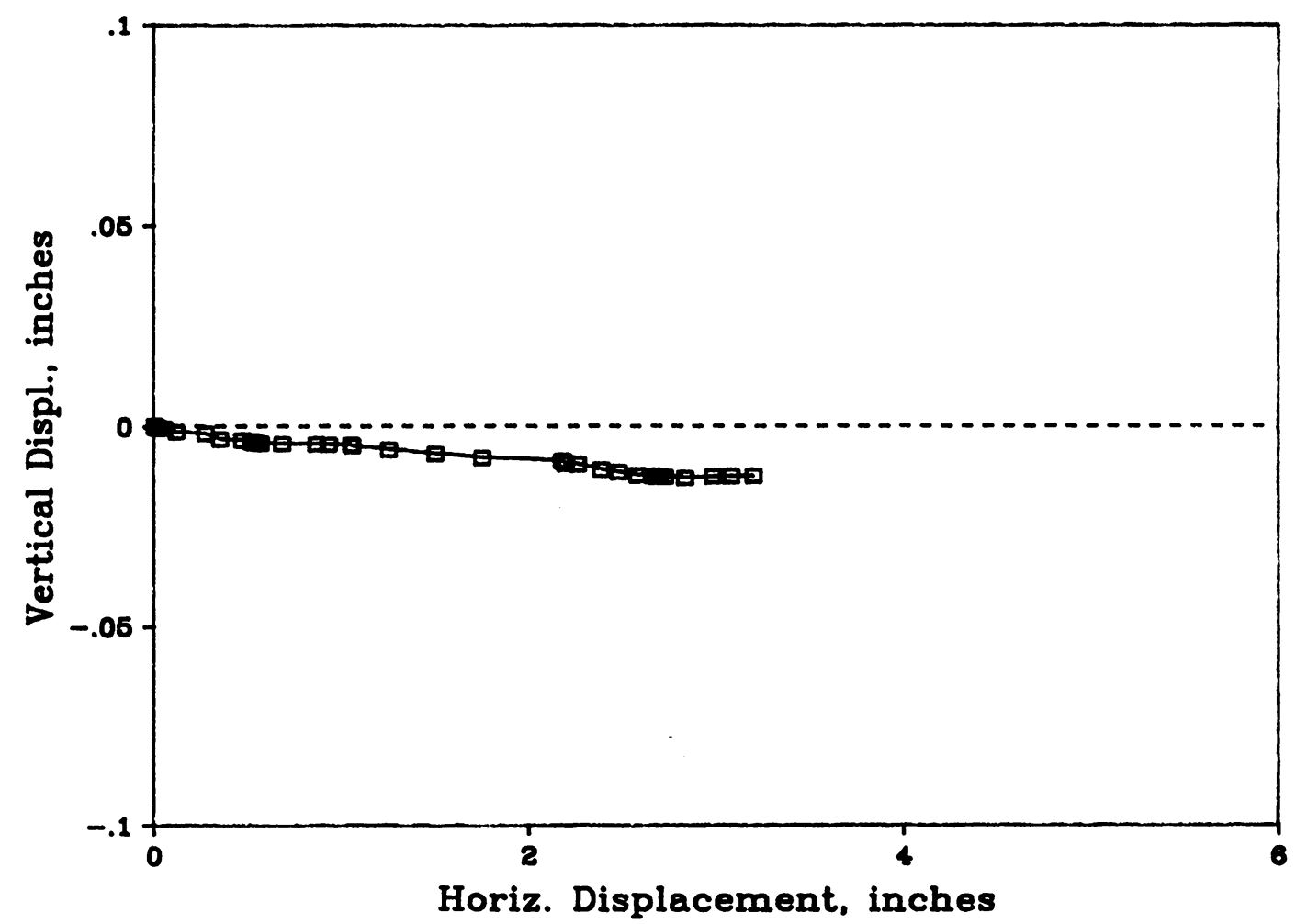

Figure C-20 Direct Shear Test DS1103\#2S on Downstream Slopewash 

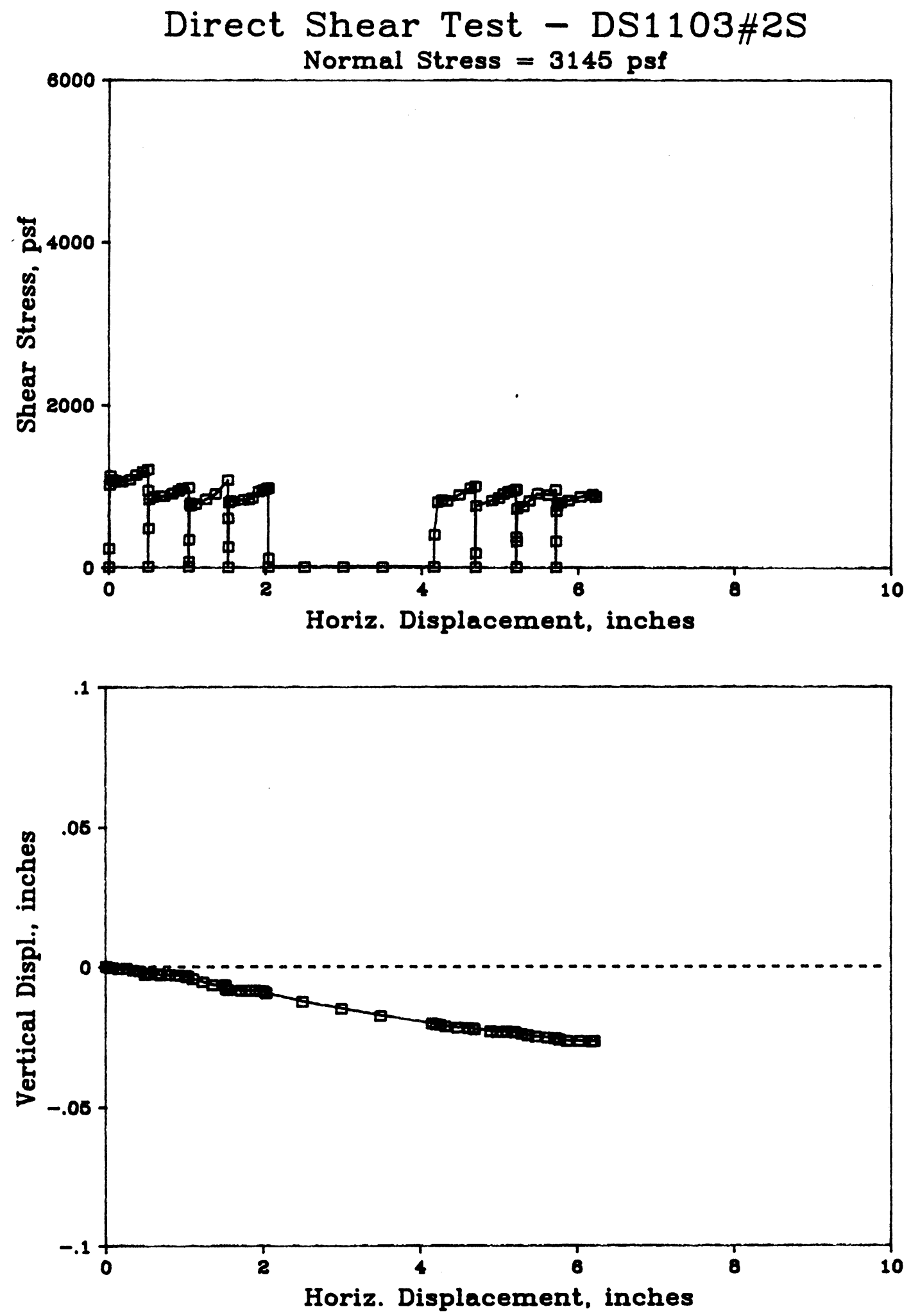

Figure C-21 Direct Shear Test DS1103\#2S on Downstream Slopewash 

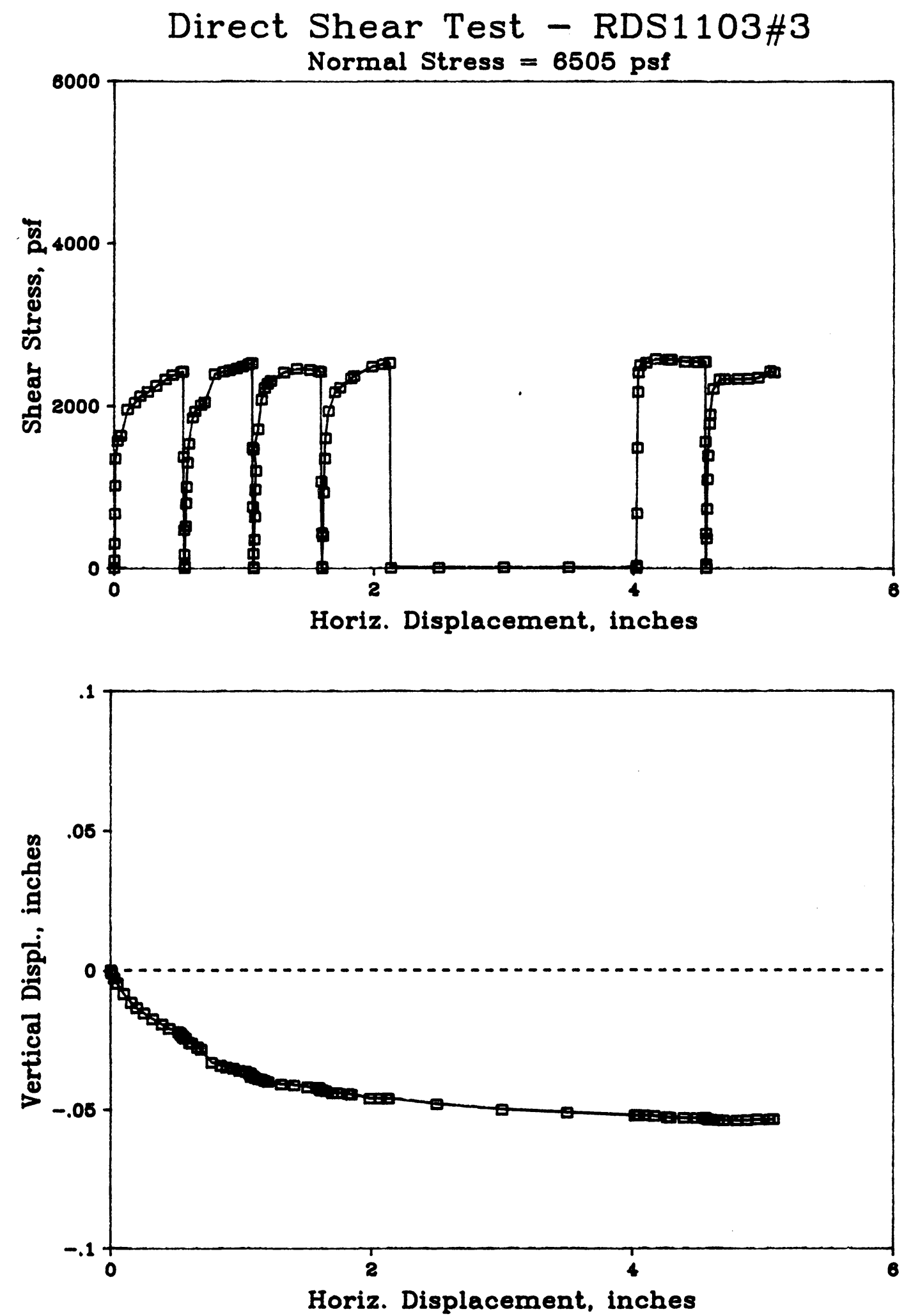

Figure C-22 Direct Shear Test RDS1103\#3 on Downstream Slopewash 

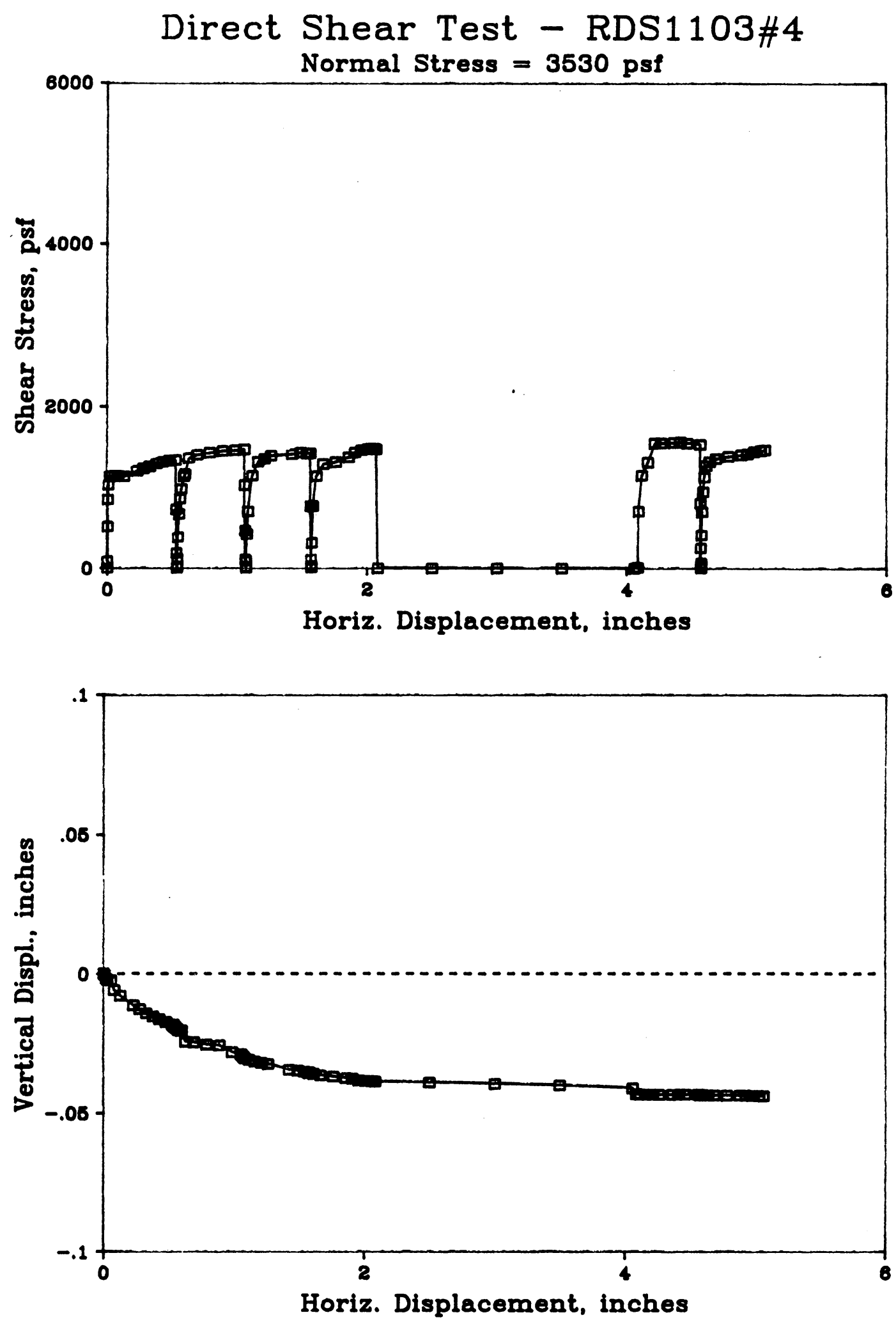

Figure C-23 Direct Shear Test RDS1103\#4 on Downstream Slopewash 
Direct Shear Test - DS1103\#5
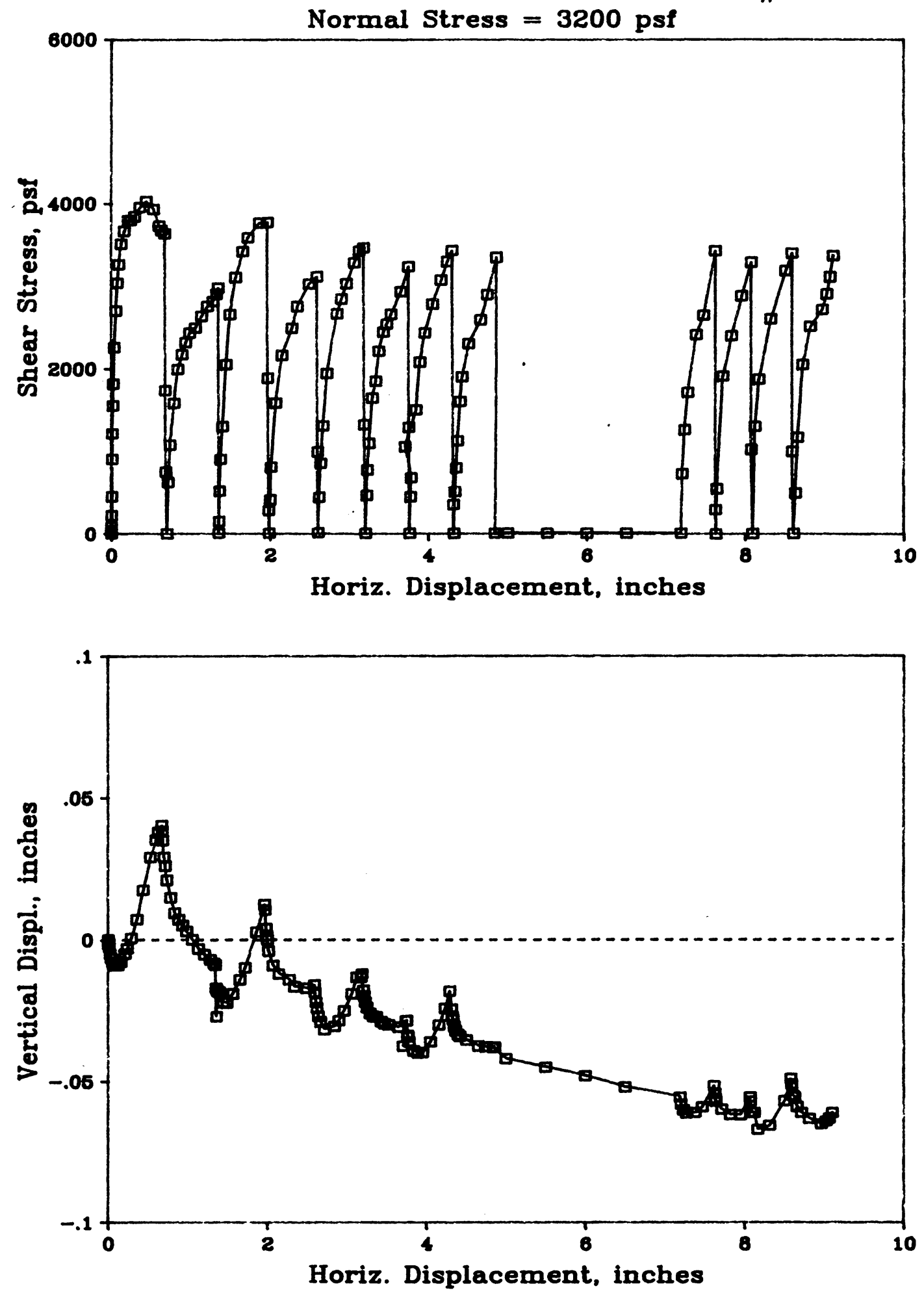

Figure C-24 Direct Shear Test DS1103\#5 on Downstream Slopewash 
Direct Shear Test - DS1103\#5S

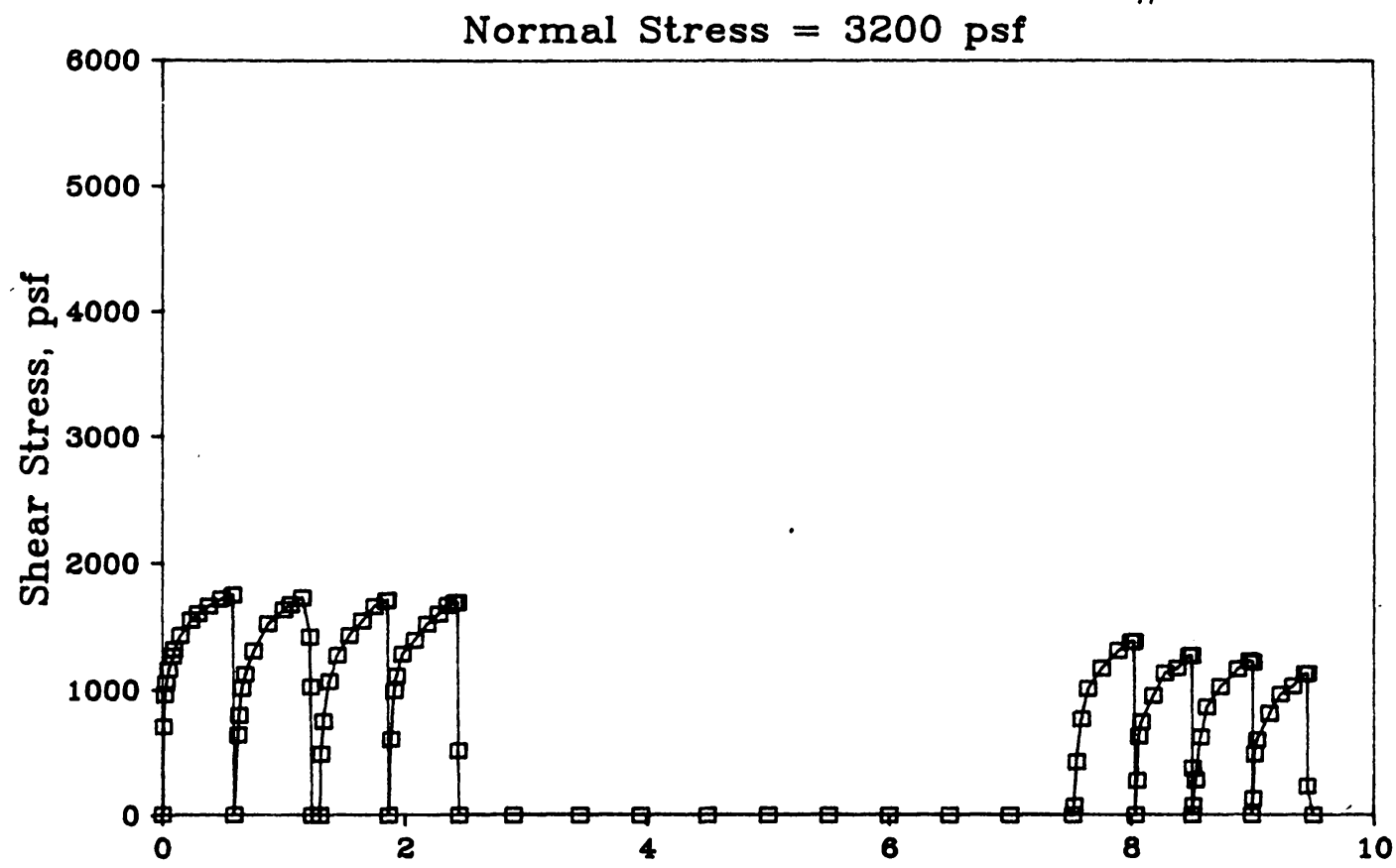

Horiz. Displacement, inches

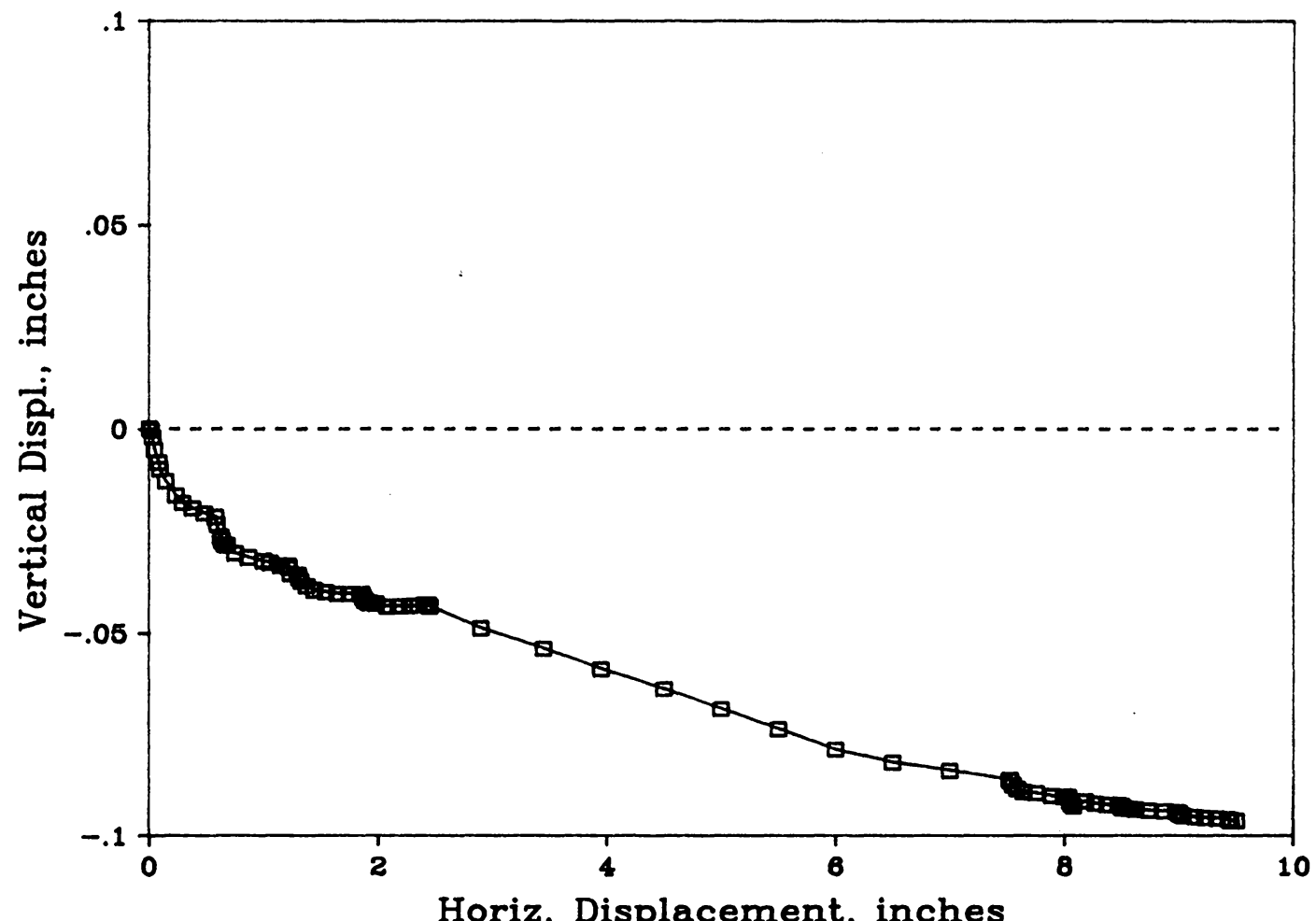

Horiz. Displacement, inches

Figure C-25 Direct Shear Test DS1103\#5S on Downstream Slopewash 

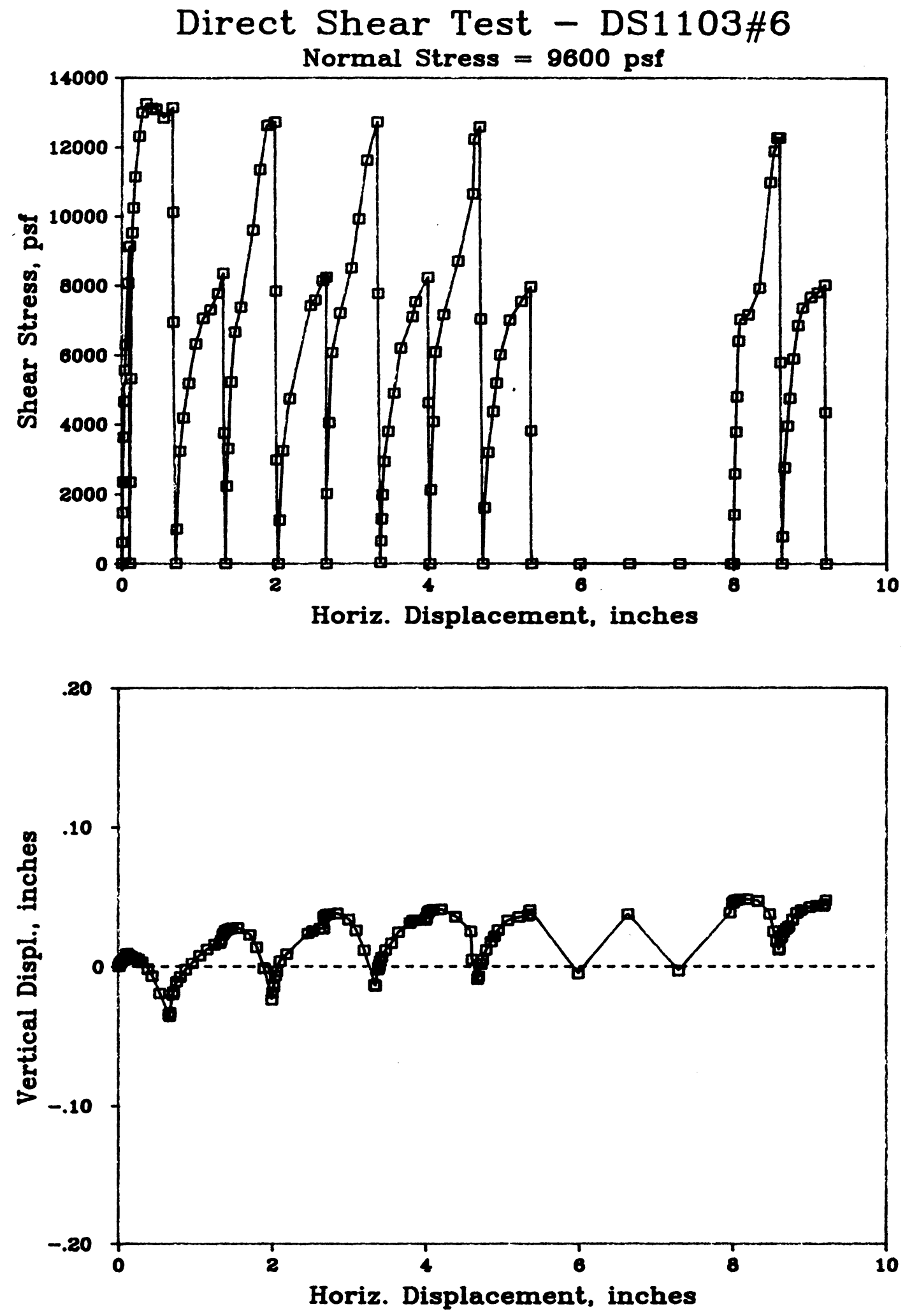

Figure C-26 Direct Shear Test DS1103\#6 on Downstream Slopewash 

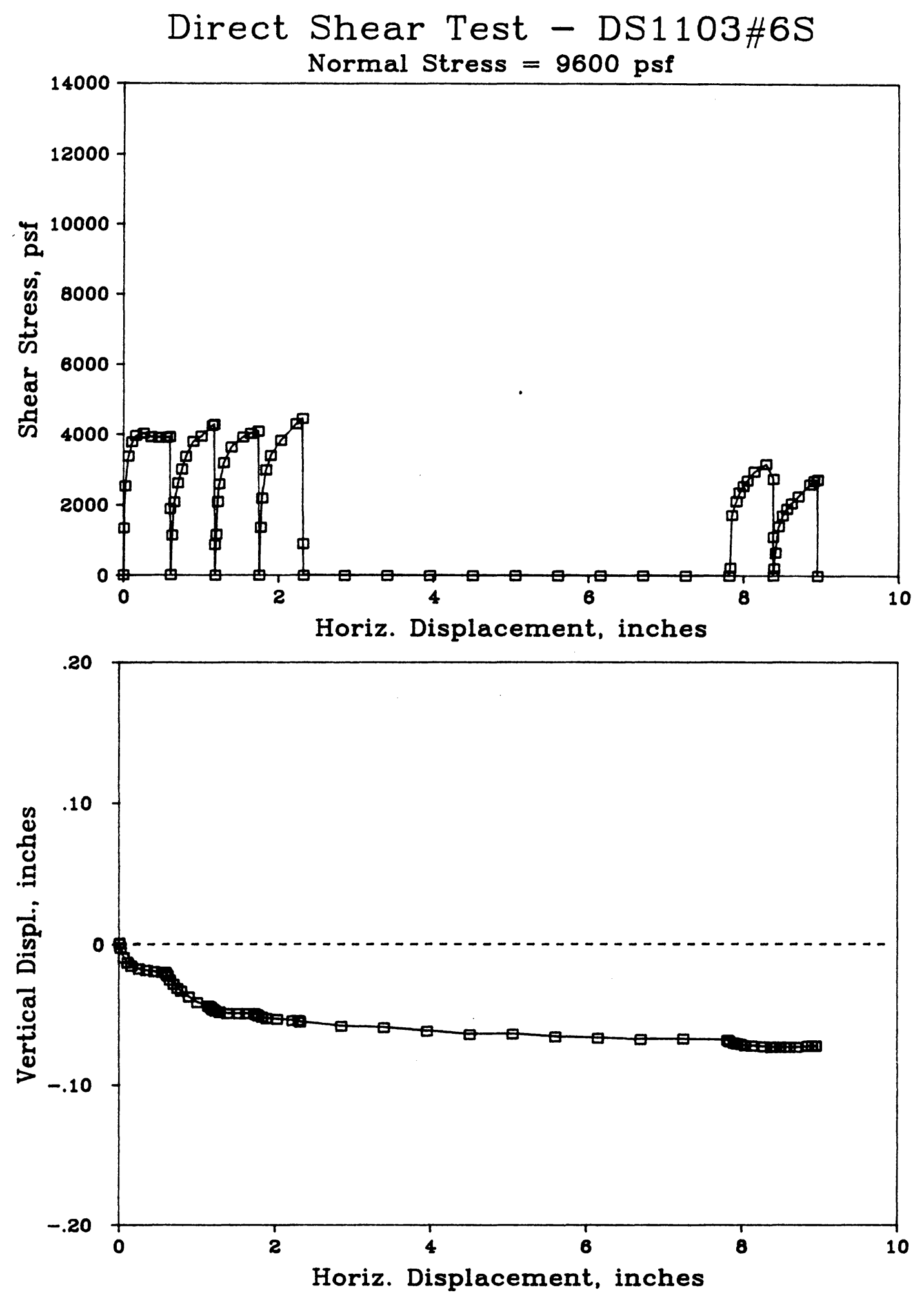

Figure C-27 Direct Shear Test DS1103\#6S on Downstream Slopewash 

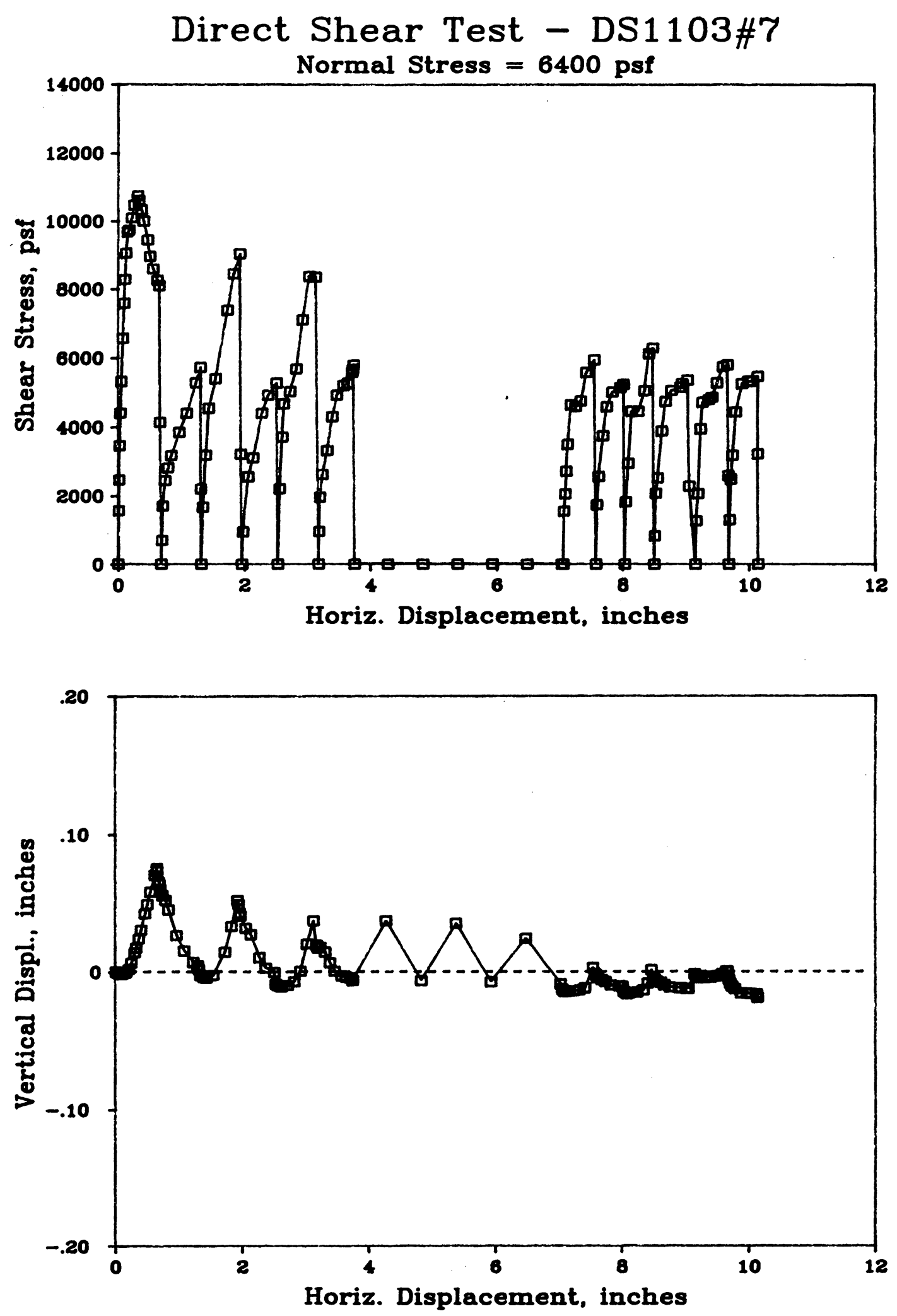

Figure C-28 Direct Shear Test DS1103\#7 on Downstream Slopewash 
Direct Shear Test DS1103\#7S
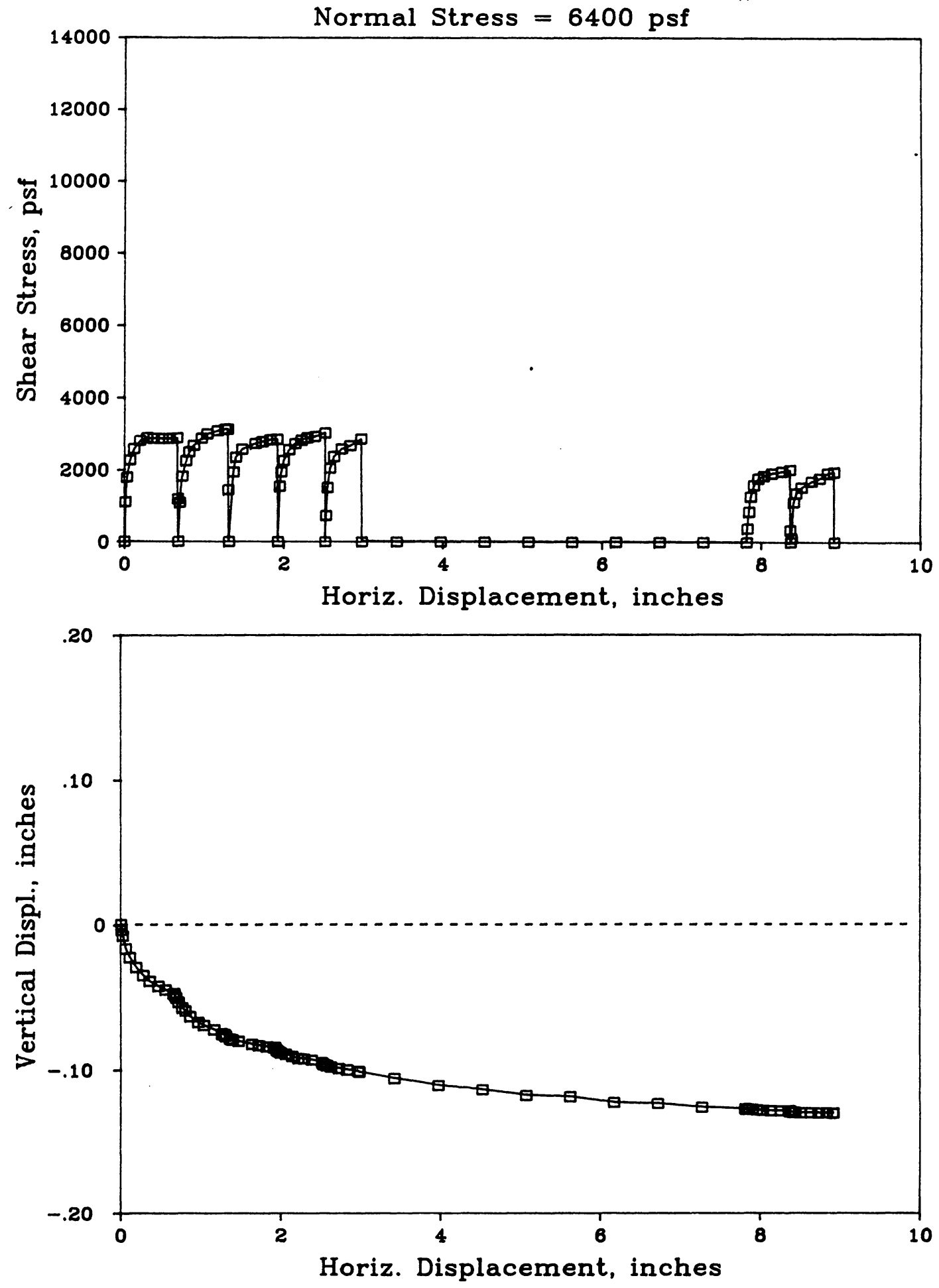

Figure C-29 Direct Shear Test DS1103\#7S on Downstream Slopewash 

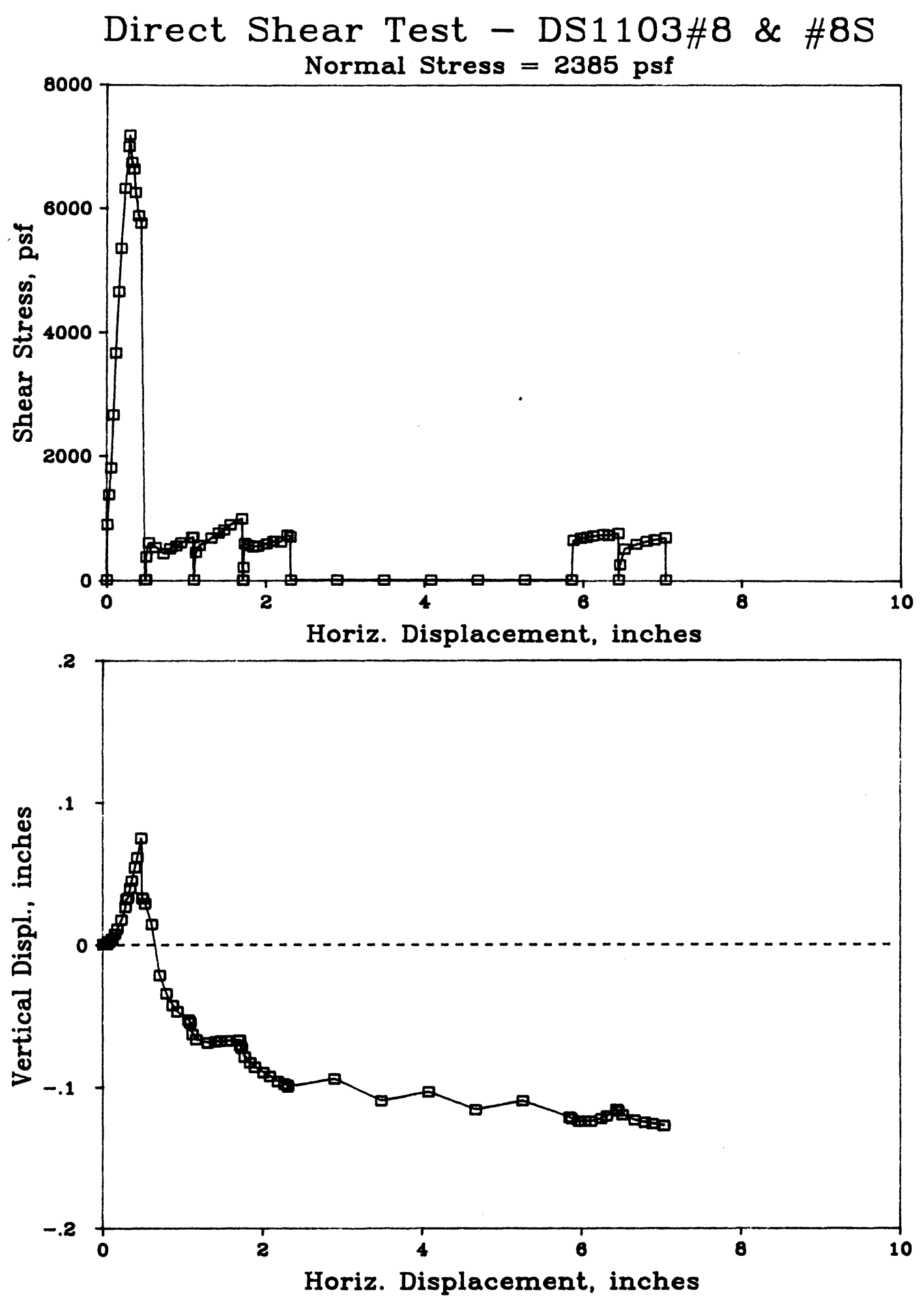

Figure C-30 Direct Shear Test DS1103\#8 \& \#8S on Downstream Slopewash 
Direct Shear Test - DS765\#1 \& \#1S
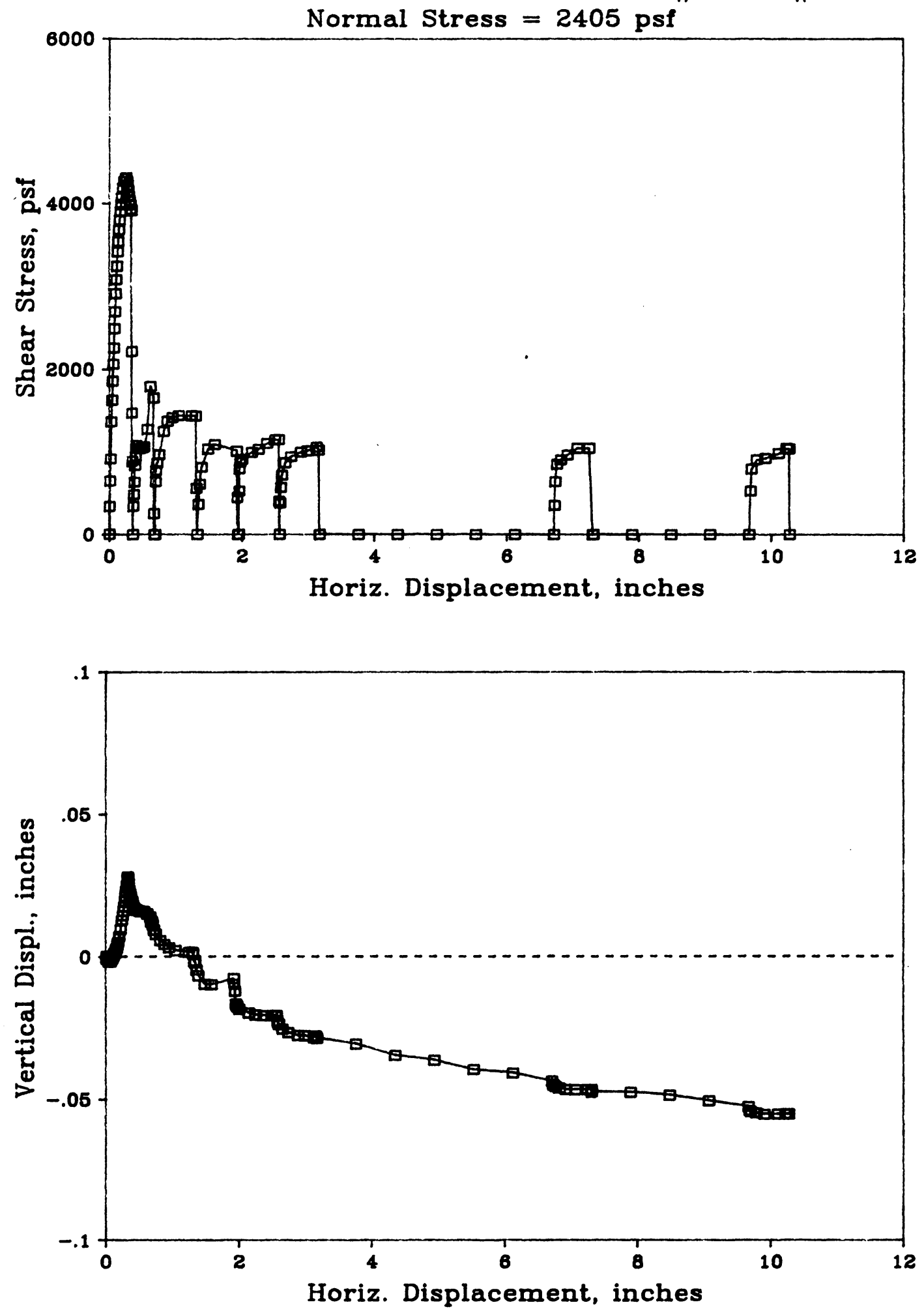

Figure C-31 Direct Shear Test DS765\#1 \& \#1S on Downstream Slopewash 

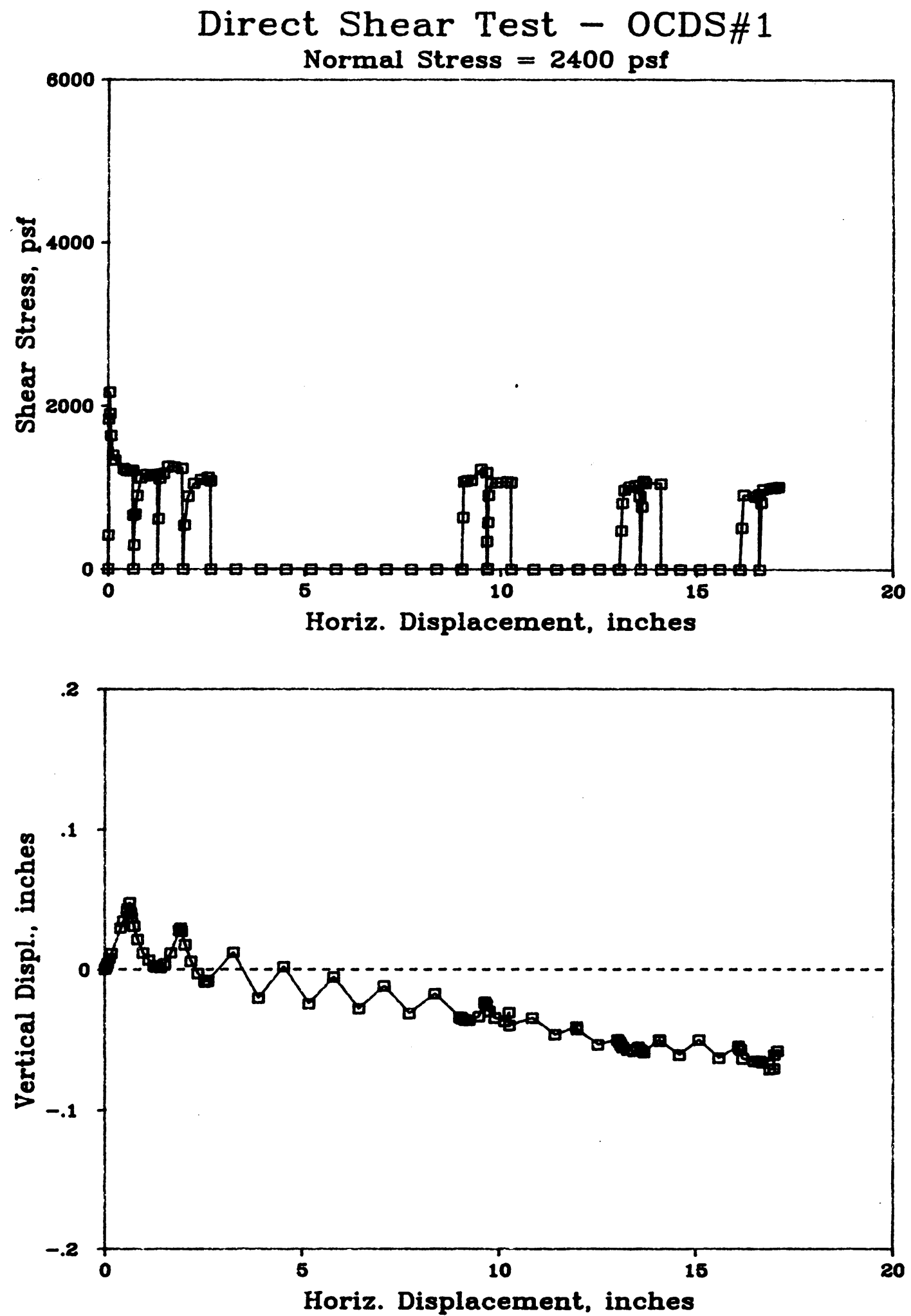

Figure C-32 Direct Shear Test OCDS\#1 on Downstream Slopewash 

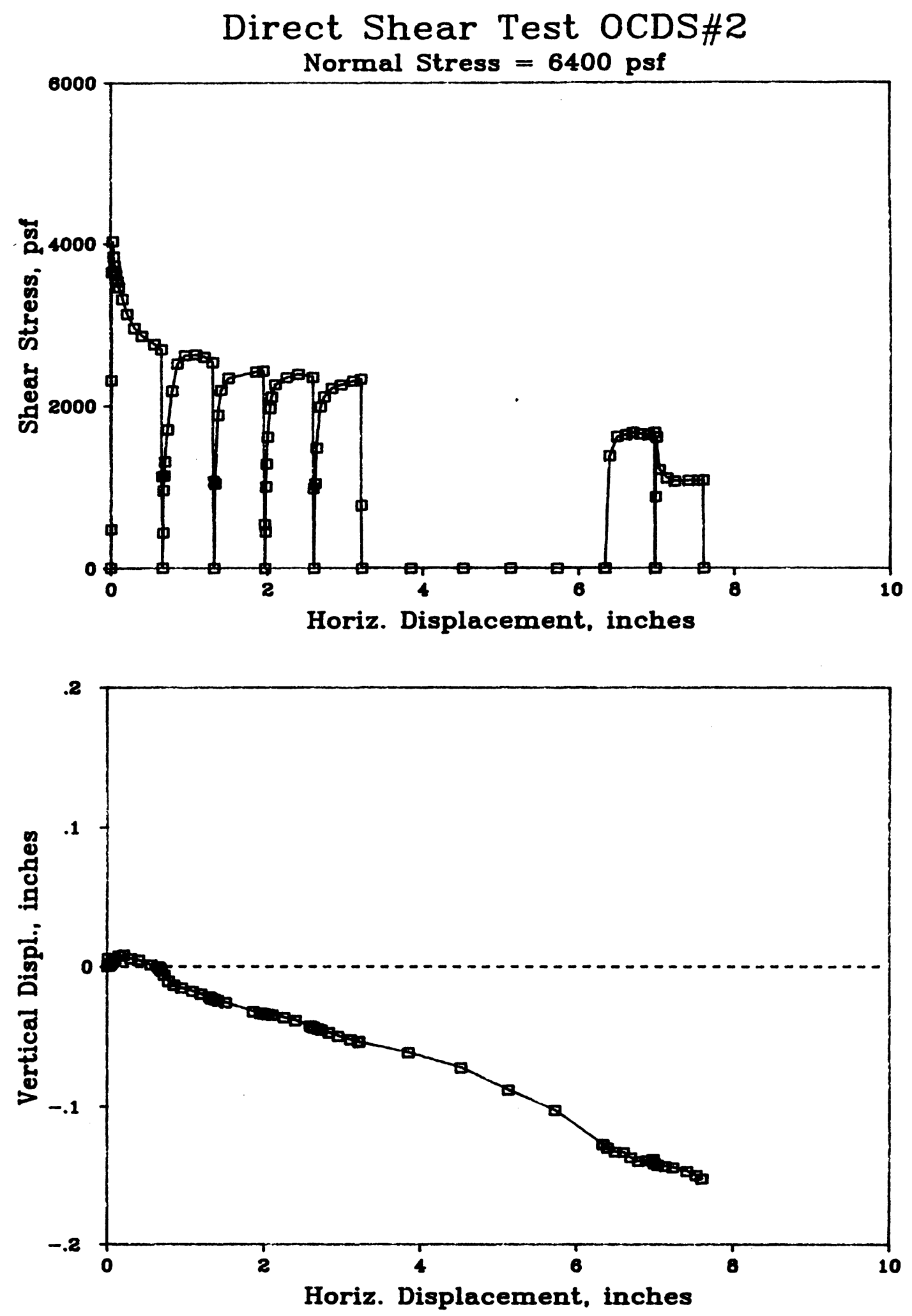

Figure C-33 Direct Shear Test OCDS\#2 on Downstream Slopewash 

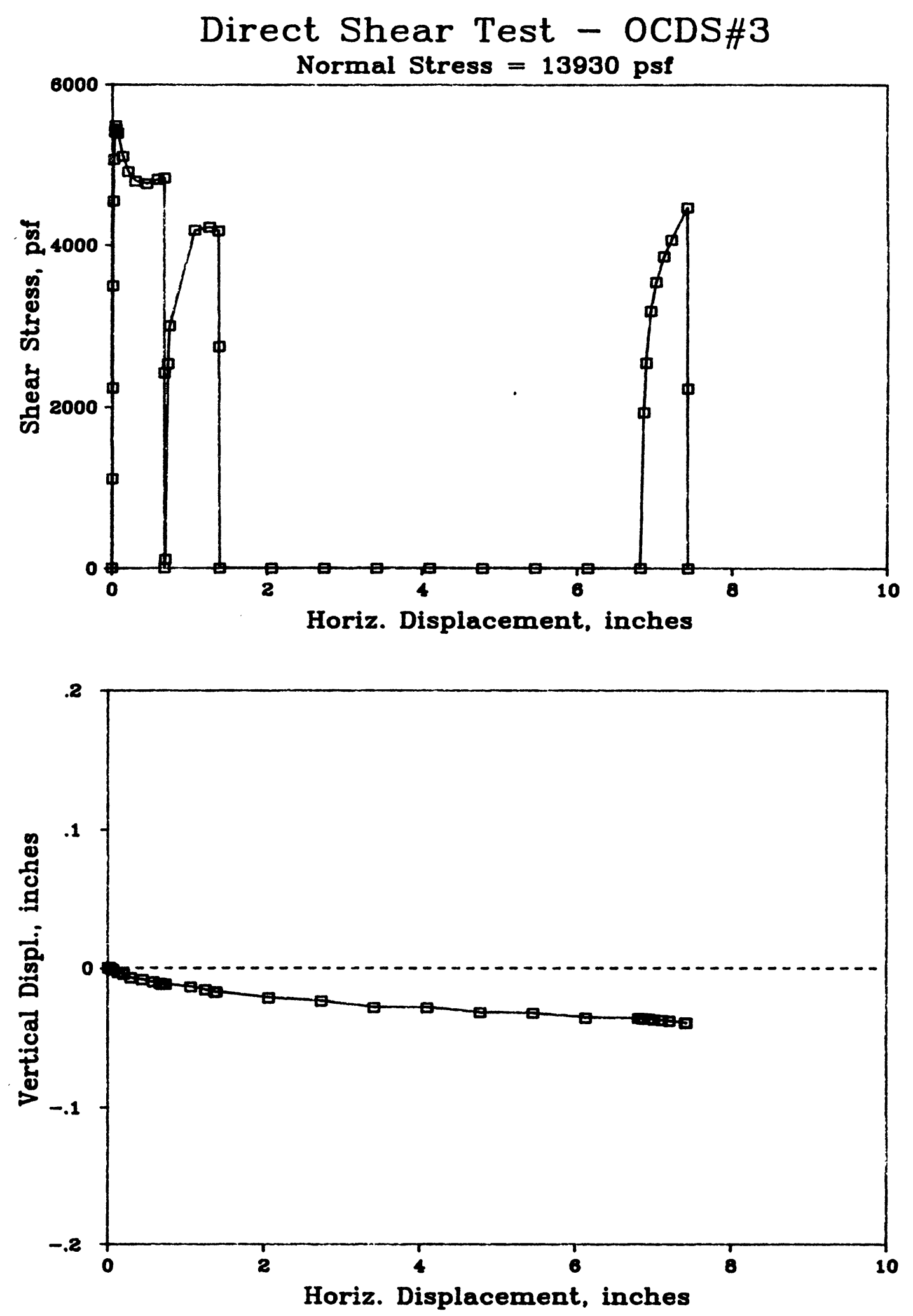

Figure C-34 Direct Shear Test OCDS\#3 on Downstream Slopewash 

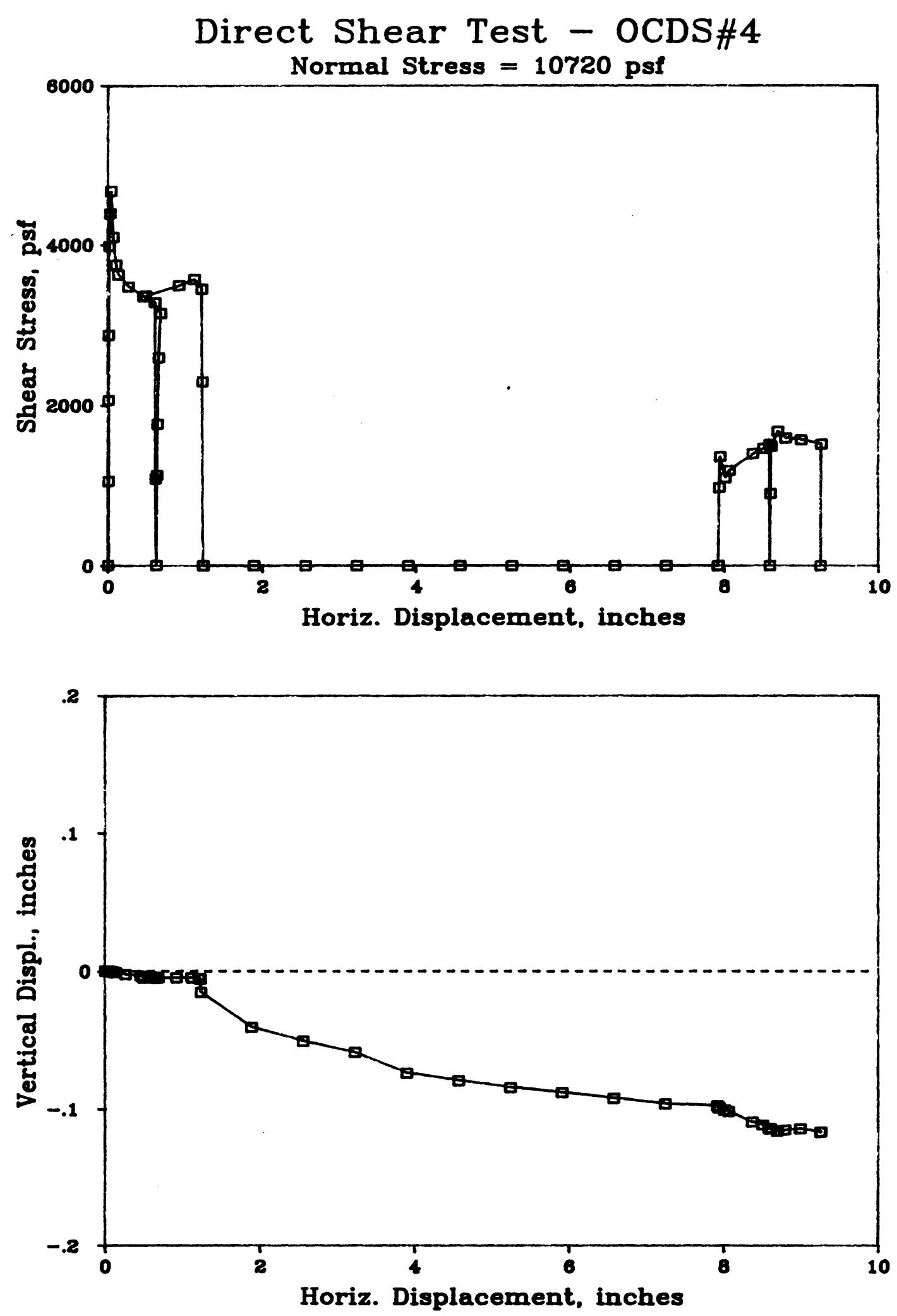

Figure C-35 Direct Shear Test OCDS\#4 on Downstream Slopewash 


\section{The vita has been removed from the scanned document}

